\title{
Value Creation and Leveraged Buyouts (LBOs)
}

BY

Binbin Cui, B.A., M.A.

\begin{abstract}
A thesis submitted to
The Faculty of Graduate Studies and Research

in partial fulfillment of the requirements for the degree of

Doctor of Philosophy
\end{abstract}

\author{
Sprott School of Business \\ Carleton University \\ Ottawa, Ontario
}

May, 2008

(a) Copyright

2008, Binbin Cui 


$\begin{array}{ll}\begin{array}{l}\text { Library and } \\ \text { Archives Canada }\end{array} & \begin{array}{l}\text { Bibliothèque et } \\ \text { Archives Canada }\end{array} \\ \begin{array}{l}\text { Published Heritage } \\ \text { Branch }\end{array} & \begin{array}{l}\text { Direction du } \\ \text { Patrimoine de l'édition }\end{array} \\ \begin{array}{l}\text { 395 Wellington Street } \\ \text { Ottawa ON K1A 0N4 } \\ \text { Canada }\end{array} & \begin{array}{l}\text { O95, rue Wellington } \\ \text { Ottawa ON K1A 0N4 } \\ \text { Canada }\end{array}\end{array}$

Your file Votre référence ISBN: 978-0-494-40516-1

Our file Notre référence

ISBN: 978-0-494-40516-1

NOTICE:

The author has granted a nonexclusive license allowing Library and Archives Canada to reproduce, publish, archive, preserve, conserve, communicate to the public by telecommunication or on the Internet, loan, distribute and sell theses worldwide, for commercial or noncommercial purposes, in microform, paper, electronic and/or any other formats.

The author retains copyright ownership and moral rights in this thesis. Neither the thesis nor substantial extracts from it may be printed or otherwise reproduced without the author's permission.
AVIS:

L'auteur a accordé une licence non exclusive permettant à la Bibliothèque et Archives Canada de reproduire, publier, archiver, sauvegarder, conserver, transmettre au public par télécommunication ou par l'Internet, prêter, distribuer et vendre des thèses partout dans le monde, à des fins commerciales ou autres, sur support microforme, papier, électronique et/ou autres formats.

L'auteur conserve la propriété du droit d'auteur et des droits moraux qui protège cette thèse. $\mathrm{Ni}$ la thèse ni des extraits substantiels de celle-ci ne doivent être imprimés ou autrement reproduits sans son autorisation.
In compliance with the Canadian

Privacy Act some supporting forms may have been removed from this thesis.

While these forms may be included in the document page count, their removal does not represent any loss of content from the thesis.
Conformément à la loi canadienne sur la protection de la vie privée, quelques formulaires secondaires ont été enlevés de cette thèse.

Bien que ces formulaires aient inclus dans la pagination, il n'y aura aucun contenu manquant.

\section{Canada}




\begin{abstract}
This empirical study is believed to be the first study that comprehensively investigates the significant changes in leveraged buyout (LBO) deal characteristics, sources of value created for shareholders of LBO target firms through LBO transactions, and motivations behind LBOs over an extended and recent period (1985-2005). The findings on these three subtopics shed further light on the three key working theories, namely, the free cash flow hypothesis (the FCF hypothesis), the heterogeneity hypothesis, and the overheated market hypothesis. ${ }^{1}$
\end{abstract}

Compared to previously conducted studies, this study makes two distinct improvements on research methodology: 1) It properly characterises the definition of $\mathrm{LBO}$, and further separates institution-led buyout (LIBO) from management-led buyout (LMBO) due to the significant differences in their characteristics. 2) It adopts a proper statistical method (namely, conditional logistic regression) to deal with the 1-1 matched case-control sample.

Compared to the conclusions of the existing literature mainly focusing on LBOs in the 1980 s, the findings of this study provide additional implications for the changes in value sources and motivations of LBOs over the study period 1985-2005: 1) LMBO deal characteristics have significantly changed over time. 2) The value sources and motivations of LBOs have changed significantly as well, thus the insights of previous literature based on LBOs in the 1980s can not be generalized across recent time periods. 3) The LBO market in recent years has overheated like it did in the late 1980s. Greater availability of debt financing in recent years is found to be one of the reasons that may have caused this overheating.

Overall, this study finds that the results are period specific and sample dependent. More importantly, the applicability of both the free cash flow hypothesis and the heterogeneity hypothesis is greatly affected by the overheated LBO market conditions.

\footnotetext{
1 The free cash flow hypothesis argues that the large debt-service payments incurred by LBO transactions force managers to find ways to generate cash and, more importantly, force them to disgorge the excess free cash flow that would otherwise be invested unwisely, resulting in reduction of the agency cost (Jensen, 1986). The heterogeneity hypothesis indicates that the population of LBO is heterogeneous in managerial ownership and there are actually two types of poorly performing firms that go private through LBOs with different motivations (Halpern et al, 1999). Note that this study extends their idea and the heterogeneity hypothesis of this study argues that institution-led LBOs and management-led LBOs have different value sources and motivations (See Section 1.2 for more explanations). The overheated LBO market hypothesis is defined as the demand push from the public junk bond market resulting in the LBOs to be more aggressively priced and more susceptible to costly financial distress (Kaplan \& Stein, 1993).
} 


\section{ACKNOWLEDGEMENTS}

I would like to thank all people who have helped and inspired me during my doctoral study. Since it is impossible to thank them all, I will therefore only mention those without whom this thesis could never have been accomplished.

I would like to express my deep and sincere gratitude to my supervisor, Chancellor's Professor Vijay Jog at Sprott School of Business at Carleton University. He introduced me to this interesting topic of my PhD thesis; He provided invaluable supervision, advice, and guidance at the very early stage of this research; He also provided timely comments on the many drafts I submitted to him and great suggestions for some important research issues. In addition, Professor Jog gave me the opportunity to work with him in the consulting industry, which broadened my perspective on the practical aspects in the industry. I am indebted to him more than he knows.

I am equally thankful to Professor Roland Thomas, acting dean of Sprott School of Business at Carleton University, for his invaluable guidance in statistical analysis. Despite his busy schedule, he always kindly granted me his time for reading many drafts of my thesis and answering my questions. He provided constructive comments and suggestions that have significantly improved the research methodology section of this thesis.

I owe my most sincere gratitude to my committee members during the oral defense: Professor Sean Cleary at St. Mary's University, Professor Howard Nemiroff at Sprott School of Business at Carleton University, and Professor Michael Demers at Economics Department at Carleton University.

I wish to extend my warmest thanks to my colleagues and friends who gave me spiritual support and encouragement. Thank my best friends, Frankie Wong and Shawn Smith, for the language corrections in the final draft of this thesis. A special thank to my boyfriend $\mathrm{Nan} \mathrm{Li}$, who has always been a constant source of encouragement during my graduate study.

My deepest gratitude goes to my parents, Baoru Cui and $\mathrm{Yan} \mathrm{Li}$ for their love and support throughout my life. Without their encouragement and understanding it would have been impossible for me to finish this work. 
TABLE OF CONTENTS

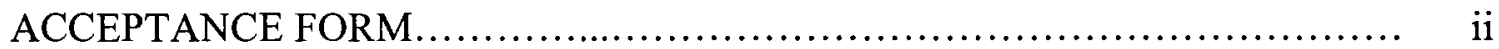

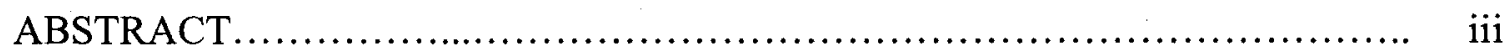

ACKNOWLEDGEMENTS.................................................. iv

TABLE OF CONTENTS ................................................... v v

LIST OF TABLES ............................................................... vii

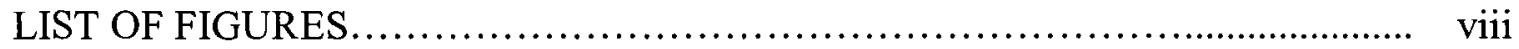

CHAPTER 1: INTRODUCTION........................................... 1

1.1 Motivation and Research Framework ............................................ 1

1.2 Overview of Key Results and Contributions of this Study..................................... 5

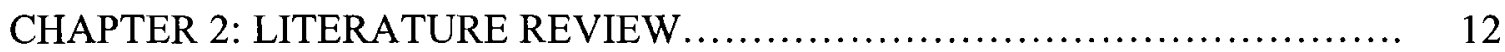

2.1 Explanation of LBO Value Source related Theories .................................. 12

2.1.1 Three Key Working Theories of This Study ................................................... 13

2.1.2 Two additional Working Theories of This Study ........................................... 15

2.2 Literature Review on Three Subtopics of This Study ......................................... 17

2.2.1 Literature Review on Changes in LBO Deal Characteristics ............................. 17

2.2.2 Literature Review on Premiums Paid to Shareholders of LBOS and the Explanatory

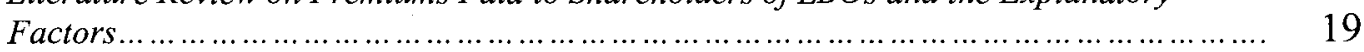

2.2.3 Literature Review on Factors Explaining the Likelihood of Firms' Going Private via

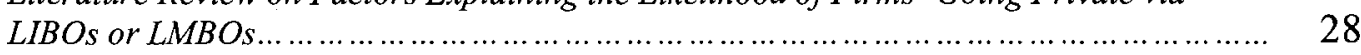

2.2.4 Literature Review on Sampling Issue and Statistical Method ................................. 36

CHAPTER 3: RESEARCH METHODOLOGY ............................. 45

3.1 Changes in Characteristics of LIBOs and LMBOs over the Period 1985-2005........... 45

3.1 .1 Hypothesis Development .................................................... 45

3.1 .2 Research Methodology ............................................................. 48

3.2 Explanatory Factors of the Premiums Paid to Shareholders of LIBOs and LMBOs............. 48

3.2.1 Hypothesis Development ................................................................ 48

3.2 .2 Research Methodology.......................................................... 54

3.3 Explanatory Factors of the Likelihood of Firms' Going Private via LIBOs or

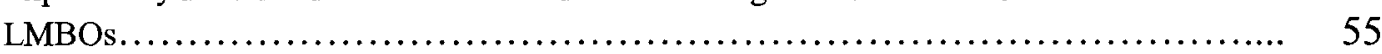

3.3.1 Hypothesis Development ........................................................... 55

3.3.2 Research Methodology..................................................................... 57

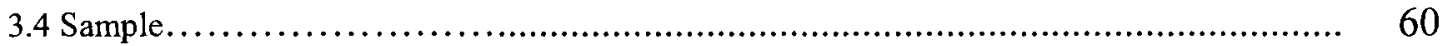

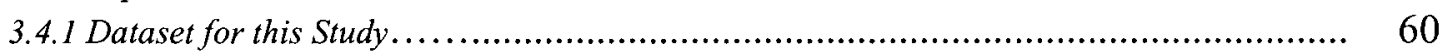

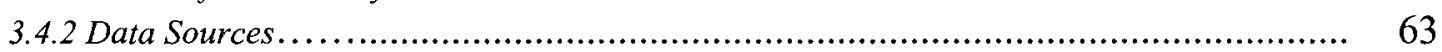

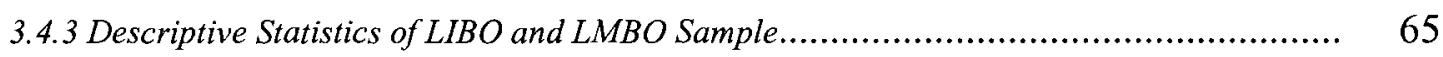

CHAPTER 4: RESULTS: Changes in LBO Deal Characteristics............................ 69

4.1 Changes in LMBO Deal Characteristics over Time.......................................................... 69

4.2 Changes in LIBO Deal Characteristics over Time................................................. $\quad 74$

4.3 Differences in Deal Characteristics between LMBOs and LIBOs................................ 75

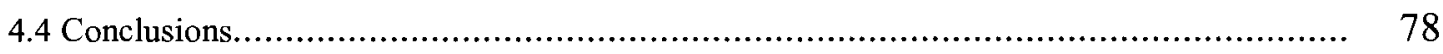


Chapter 5: Results: Premiums Paid to Shareholders of LIBOs and LMBOs and Explanatory Factors............................................................................

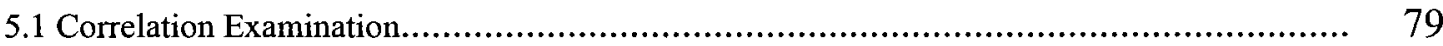

5.2 OLS Regression on LBO Premiums over Three Sub periods................................................. 84

Chapter 6: Results: Explanatory Factors of the Likelihood of Firms' Going Private via LIBOs or LMBOs.

6.1 Differentiating Characteristics between LBOs and 1-1 Matched Control Firms

98

6.2 Conditional Logistic Regression on the Likelihood of Firms' Going Private via

LBOs.

6.3 Comparison of the Results between Classical Logistic Regression and Conditional Logistic

Regression.

CHAPTER 7: SUMMARY AND CONCLUSIONS

CHAPTER 8: CONTRIBUTIONS, LIMITATIONS, AND SUGGESTIONS FOR FURTHER RESEARCH.

8.1 Major Contributions of this Study

8.2 Implications for Market Participants and Researchers.

125

8.3 Limitations.

128

8.4 Suggestions for Future Research.

REFERENCES

APPENDIX A: STRUCTURAL CHANGS IN FINANCIAL AND ECONOMIC ENVIRONMENT FOR LBO MARKET ......................

APPENDIX B: SAMPLE SIZE AND SAMPLE PERIOD OF THE KEY STUDIES ON U.S LBOS.

APPENDIX C: LITERATURE REVIEW ON LBO DEFINITION USED IN THE PREVIOUS LITERATURE.

APPENDIX D: MAJOR OBSERVATIONS ON CHANGING DEAL CHARACTERISTICS OF LIBOS AND LMBOS BASED ON RAW DATA OF THIS STUDY.....

APPENDIX E: GENERAL LITERATURE REVIEW ON THE RELATED RESEARCH SUBTOPICS ON LBOS (NOT COVERED BY THIS

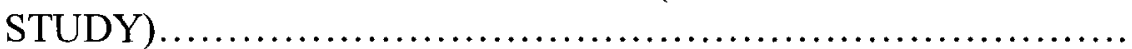

APPENDIX F: LITERATURE REVIEW ON LBO VALUE SOURCE RELATED THEORIES NOT COVERED BY THIS STUDY.

APPENDIX G: EXPLANATION OF WEIGHTED MAXIMUM LIKELIHOOD ESTIMATION

APPENDIX H: EXPLANATION OF THE LIMITATIONS OF STANDARD ESTIMATION METHOD UNDER CASE-CONTROL SAMPLING DESIGN

APPENDIX I: EXPLANATION OF A LOGIT EXEMPTION TO THE NEED FOR REWEIGHTING UNDER CASE-CONTROL SAMPLE...... 
APPENDIX J: EXPLANATION OF THE LIMITATIONS OF BOTH WEIGHTED ESTIMATION METHOD AND STANDARD ESTIMATION METHOD UNDER MATCHED CASECONTROL SAMPLING DESIGN.....

APPENDIX K: EXPLANATION OF CONDITIONAL LOGISTIC REGRESSION

\section{LIST OF TABLES}

Table 1.1 Summary of the Conclusions for the Three Key Working Theories....................................... 6

Table 2.1 Results on Explanatory Factors of the Premiums Paid to Shareholders of LBOs................... 26

Table 2.2 Results on Explanatory Factors of the Likelihood of Firms' Going Private via LBOs........ 33

Table 2.3 Research Methodologies of the Previous Studies on the Likelihood of Firms' Going Private via LBOs.

Table 3.1 Variables used to Explore Changes in Characteristics of LBOs and the Proxies....

Table 3.2 Research Hypotheses on Factors Explaining the Premiums Paid to Shareholders of LIBOs and LMBOs.

Table 3.3 Research Hypotheses on Factors Explaining the Likelihood of Firms' Undertaking LIBOs and LMBOs.

Table 3.4 Summary of the Variables Used in the Analyses of This Study (Across All Chapters) and Their Definitions.

6

(1)

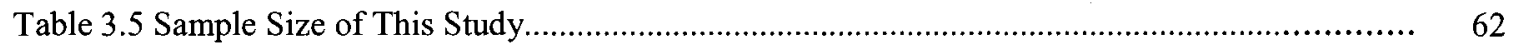

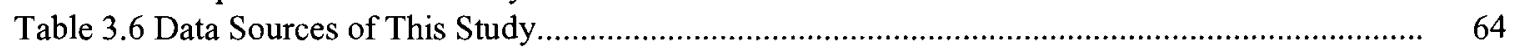

Table 3.7 Yearly Distribution of U.S. LBO Transactions over the Period 1985-2005 .......................... 66

Table 3.8 Descriptive Statistics of Deal-specific Variables and Firm-specific Variables for LIBOs and LMBOs over the Period 1985-2005 (Median)...

Table 4.1: Three-group (representing 1985-1989, 1990-1999, and 2000-2005) 1-way MANOVA Analysis for LMBOs..

Table 4.2 T-tests for Comparisons in Deal Characteristics between LMBOs over the 1985-1989 and LMBOs over the 2000-2005.

Table 4.3: 2-group (representing 1995-1999 and 2000-2005) 1-way MANOVA Analysis for LIBOs..

Table 4.4 MANOVA Analysis for the Differences in Deal Characteristics between LMBOs and LIBOs over the Period 1995-2005.

Table 4.5 Summary of Changes in LBO Deal Characteristics........................................................... 78

Table 5.1 Pearson Correlation Analysis............................................................................................ 80

Table 5.2 OLS Regression on LBO Premiums over the Sub Period 1985-1989 .................................. 85

Table 5.3 OLS Regression on LBO Premiums over the Sub Period 1990-1999.................................... 86

Table 5.4 Separate OLS Regression on LBO Premiums for LIBOs and LMBOs over the Sub Period 1990-1999.

Table 5.5 OLS Regression on LBO Premiums over the Sub Period 2000-2005.

Table 5.6 Separate OLS Regression on LBO Premiums for LIBOs and LMBOs over the Sub Period 2000-2005.

Table 5.7 Separate OLS Regression on LBO Premiums for LMBOs with Higher Level of Pre-buyout Managerial Ownership and LMBOs with Lower Level of Pre-buyout Managerial Ownership over the Sub Period 2000-2005.

Table 5.8 Summary of Factors Explaining Premiums Paid to Shareholders of LIBOs and LMBOs

Table 6.1 Univariate Analysis for Differences between LBOs (including LIBOs and LMBOs) and Control Firms. 
Table 6.2 Conditional Logistic Regression on the Likelihood of Firms' Going Private via LMBOs and LIBOs over Three Sub Periods.

Table 6.3: Separate Conditional Logistic Regression on the Likelihood of Firms' Going Private via LBOs for LIBOs and LMBOs over the Sub Period 2000-2005.

Table 6.4: Separate Conditional Logistic Regression on the Likelihood of the Two Groups of Firms' Going Private via LMBOs over the Sub Period 2000-2005.

Table 6.5 Summary of Explanatory Factors of the Likelihood of Firms' Going Private via LIBOs or LMBOs

Table 6.6 Comparison of the Results between Standard Logistic Regression and Conditional Logistic Regression for Factors Explaining the Likelihood of Firms' Going Private via LBOs in the 1990 s

Table 7.1 Summary of Implications of the Major Findings for the Three Key Working Theories of This Study.....

\section{LIST OF FIGURES}

Figure 1.1: Research Framework of This Study 


\section{CHAPTER 1: INTRODUCTION}

Leveraged buyouts (LBOs) became very popular in the U.S. during the late 1980s, but went out of favor following the collapse of the junk bond market of the 1990s. The overheated market hypothesis explains this rise and decline, by indicating that LBO deals in the late 1980 s were somewhat riskier and more overvalued than those in the early 1980s. ${ }^{1}$ In recent years, LBOs have re-emerged with significant increase in number of LBO transactions and deal size. Compared to the 1980s when most of the LBOs were led by management, the 2000 s have seen a larger portion of LBOs led by institutions. Many reasons for such increased LBO activity and changes in initiators of LBOs have been proposed. They include greater availability of private equity, aggressive lending activities of financial institutions, and a robust market outside the U.S. in recent years (See Appendix A for details).

\subsection{Motivation and Research Framework}

The previous literature has mainly focused on the U.S. LBOs in the 1980s (See Appendix B for a summary of the existing key studies). Due to the dated nature of the existing literature, the need for additional empirical research on recent U.S. LBOs has been suggested by many researchers to assess whether the insights of the previous studies can be more generally applicable across more recent time periods. Furthermore, researchers and practitioners have pointed to changing trends of the characteristics of U.S. LBOs as a topic for further research (Bae \& Hoje, 2002; Kaplan \& Stein, 1993; Jin \& Wang, 2002;

\footnotetext{
${ }^{1}$ The overheated LBO market hypothesis is defined as the demand push from the public junk bond market resulting in LBOs being more aggressively priced and more susceptible to costly financial distress (Kaplan \& Stein, 1993).
} 
Eddey, Lee, \& Taylor, 1996; Allen, 1996). Inspired by the above, this study fully explores the value sources and motivations of LBOs over an extended and recent period (1985-2005).

The free cash flow hypothesis (the FCF hypothesis), one of the three key working theories explored in this study, argues that the large debt-service payments incurred by LBO transactions force managers to find ways to generate cash and to disgorge the excess free cash flow that would otherwise be invested unwisely, resulting in reduction of the agency cost (Jensen, 1986). According to the literature review, one of the main mixed empirical findings from the previous research focuses on the FCF hypothesis (See Table 2.1 and 2.2 for details). Lehn and Poulsen (1989) and Halpern et al (1999) also call for additional examination of the FCF hypothesis. Thus, this study re-examines the FCF hypothesis using improved proxies to measure the pre-buyout level of free cash flow of LBO targets and taking into account the possible differences between LIBOs and LMBOs and changes in LBO market conditions over time.

This study also finds that definitions of LBOs in the previous literature are vague and inconsistent (See Appendix C for a detailed discussion): Some studies use public-toprivate transaction and LBO interchangeably (Kaplan \& Stein, 1993); Some studies use management-led LBO and LBO interchangeably (DeAngelo, et al, 1984; Green, 1992); Some studies indicate that LBO and management-led LBO are the two most commonly used terms for public-to-private transactions (Lehn \& Poulsen, 1989; Weir, et al, 2005). Furthermore, previous studies fail to take debt financing as a requirement for a going- 
private transaction to be considered as an LBO, with exception to Halpern et al (1999). Note that faced with these ambiguous LBO definitions, this study defines an LBO as a highly leveraged (more than $30 \%$ of debt) going-private transactions (100\% of the company is acquired). ${ }^{2}$ More importantly, unlike previous studies that consider LBOs as homogenous irrespective of the type of initiator, this study further separates leveraged management-led buyouts (LMBOs) from leveraged institution-led buyouts (LIBOs) and includes both LMBOs and LIBOs as two sub-samples. There are two main advantages of this segregation: 1) Theoretically, there is a lower degree of asymmetric information between vendors and purchasers in LMBOs than in LIBOs, since management, as an informed party, is assumed to have better information about the value of firm (See Section 2.1.2 for a more detailed explanation of the asymmetric information hypothesis). This may cause different motivations behind LIBOs and LMBOs. 2) An initial data analysis of this study shows that the number of LIBOs has significantly increased since the mid 1990s (See Appendix D for details), implying that institutions currently play a more vital role in initiating LBOs than before. However, compared with the level of empirical research on LMBOs, LIBOs have been almost completely ignored in academic literature.

\footnotetext{
${ }^{2}$ The definition of this study mainly follows the LBO definition used by Halpern et al (1999) except the requirement for percentage of assumed liability. This study uses $30 \%$ ratio of assumed liability to transaction value, instead of $50 \%$ (used by Halpern et al (1999)), to define LBOs for the following two reasons: 1) There are no clear criteria regarding the minimum amount of debt financing for a going-private transaction to be considered as an LBO. Therefore, the cutoffs of assumed liability to transaction value for LBO definitions are arbitrary in any existing studies. 2) After the collapse of the LBO market in the late 1980s, firms might take on less debt, since extra risk of bankruptcies and low credit ratings cause creditors to be more conservative about accepting the extremely high leverage ratios prevalent in the 1980s. Moreover, in 1990, there were a number of going-private transactions with less than $50 \%$ of assumed liability to transaction value labelled as LBOs in the press.
} 
Overall, observations about the increase in LBO activity and the changing LBO deal characteristics and related financial markets (See Appendix A and D for details) raise three fundamental questions: Have deal characteristics of LBOs changed greatly since the late 1980s? If so, what are the sources for shareholder gains and motivations behind recent LBO transactions? Has the recent LBO market become overheated like it did in the late 1980s? In order to answer the above research questions, this study attempts to explore the three key working theories, namely, the free cash flow hypothesis, the heterogeneity hypothesis, and the overheated market hypothesis. To fully test these three key working theories, this study specifically attempts to research the three subtopics: 1 ) Changes in LBO deal characteristics; 2) Factors explaining LBO premiums; and 3) Factors explaining the likelihood of firms going private via LBOs. ${ }^{3}$

The research framework of this study is provided in Figure 1.1. Figure 1.1 mainly describes the relationships among the value source theme, the three working theories, the three subtopics, the two sub-samples, and the three sub periods. Note that the results of this study also shed additional light upon two other theories, namely, the market undervaluation hypothesis and the asymmetric information hypothesis (See Section 2.1.2 for more detailed explanations of these two theories). However, these two theories are not included in Figure 1.1, since neither of them is the main focus of this study.

\footnotetext{
${ }^{3}$ There are four main reasons why these three subtopics on LBO are selected: 1) This study tends to focus on the research subtopics that directly examine the value sources of LBO, rather than the subtopics focusing on any specific stages of LBO cycle (See Appendix E for an explanation of LBO cycle). 2) Selection of the above three subtopics is also affected by the availability of data. For example, research on the operating performance of post-LBO may also shed light on the value creation of LBO, but the data available for this subtopic is very limited. Particularly, there is no access to the financial information for most LBO firms after they are taken private. Moreover, it is impossible to explore the recent LBO deals since ultimate success or failure of the recent deals is still unknown. 3) The subtopic on explanatory factors of the likelihood of firms' going private via LBOs (Subtopic 3) directly explores the motivations of LBOs. However, the explanatory factors of LBO premiums identified within Subtopic 2 not only represent the motivations behind LBOs, but also have characteristics of being easily appropriated by the other buyers once the LBO announcement signals the existence of benefits.
} 


\section{Figure 1.1: Research Framework of This Study}

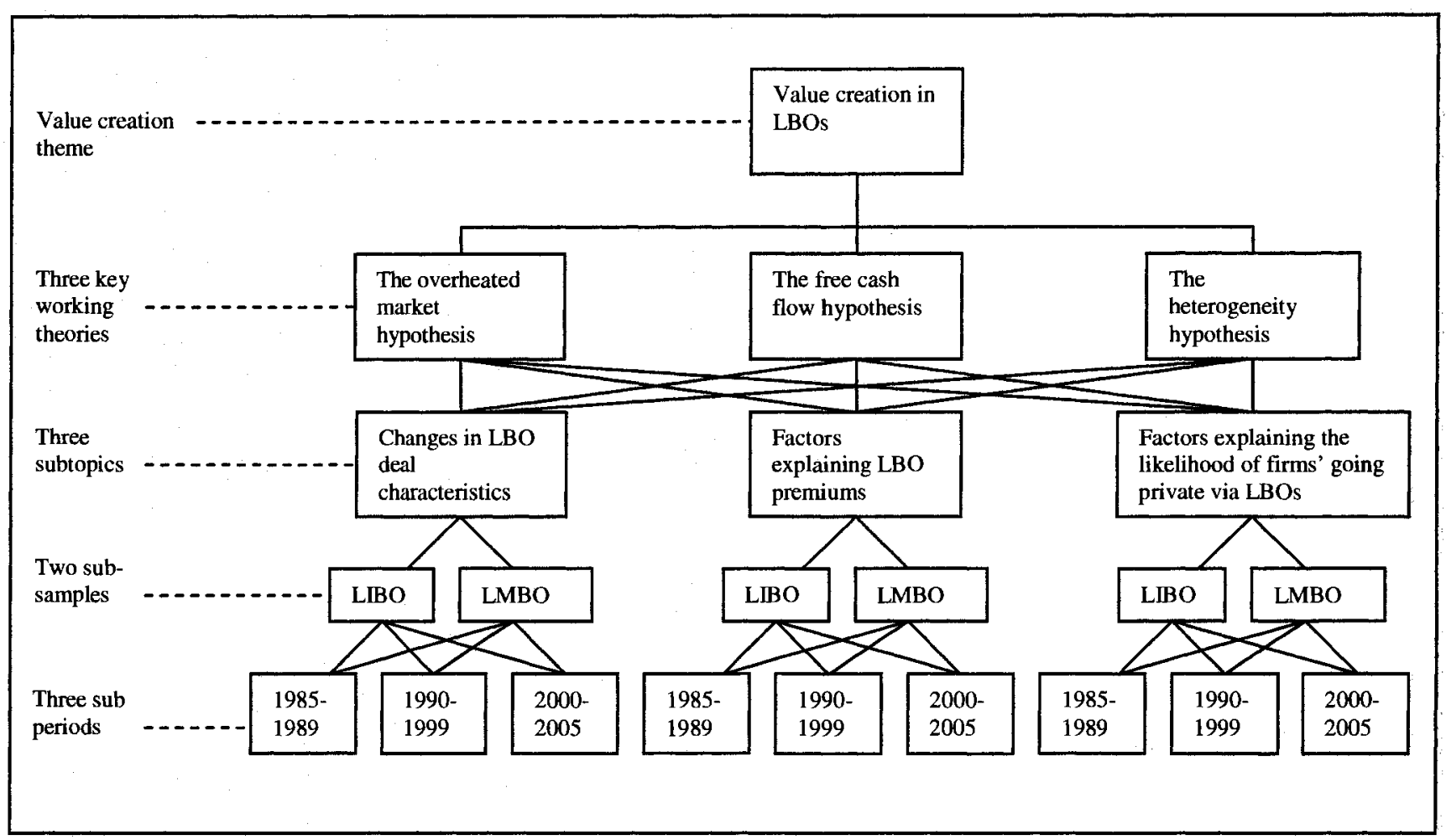

\subsection{Overview of Key Results and Contributions of this Study}

This section provides an overview to the key empirical results and the contributions of this study. First, the conclusions for the three key working theories of this study are summarized in Table 1.1. Then, the major empirical findings on the three subtopics and their implications for the three key working theories are described. 
Table 1.1 Summary of the Conclusions for the Three Key Working Theories

\begin{tabular}{|l|l|l|l|}
\hline $\begin{array}{l}\text { Key Working } \\
\text { Theory/Time Period }\end{array}$ & $1985-1989$ & $1990-1999$ & $2000-2005$ \\
\hline $\begin{array}{l}\text { The free cash flow } \\
\text { hypothesis }\end{array}$ & $\begin{array}{l}\text { LMBO: Fail to support } \\
\text { LIBO:N/A }\end{array}$ & $\begin{array}{l}\text { LMBO: Support } \\
\text { LIBO: Support }\end{array}$ & $\begin{array}{l}\text { LMBO: Fail to support } \\
\text { LIBO: Support }\end{array}$ \\
\hline $\begin{array}{l}\text { The heterogeneity } \\
\text { hypothesis }\end{array}$ & $\begin{array}{l}\text { LBO (LMBO+LIBO): } \\
\text { N/A }\end{array}$ & $\begin{array}{l}\text { LBO (LMBO+LIBO): } \\
\text { Fail to support }\end{array}$ & $\begin{array}{l}\text { LBO (LMBO+LIBO): } \\
\text { Support }\end{array}$ \\
\hline $\begin{array}{l}\text { The overheated market } \\
\text { hypothesis }\end{array}$ & $\begin{array}{l}\text { LMBO: Support } \\
\text { LIBO:N/A }\end{array}$ & $\begin{array}{l}\text { LMBO: Fail to support } \\
\text { LIBO: Fail to support }\end{array}$ & $\begin{array}{l}\text { LMBO: Support } \\
\text { LIBO: Fail to support }\end{array}$ \\
\hline
\end{tabular}

Note: Based on the dataset of this study, LIBOs did not take place until the mid 1990s. Thus the above three working theories are not tested on LIBOs over the sub period 1985-1989.

Note that this study extends Halpern et al (1999)'s idea of the heterogeneity hypothesis which states that the LBO population is heterogeneous in managerial ownership. Instead of arguing that LBOs are heterogeneous in managerial ownership, this study considers the heterogeneity of LBOs in the type of initiators. Particularly, this study tests whether LIBO differs from LMBO in terms of deal characteristics, value sources, and motivations. ${ }^{4}$ The main reason for this extension is that compared to segmenting LBOs into two sub-groups based on the pre-buyout level of managerial ownership, this study provides more practical implications by separating LIBOs from LMBOs due to the potential differences between them. ${ }^{5}$

\footnotetext{
${ }^{4}$ In practice, the acquirers of LBOs can include outside individuals, institutions, non-financial firms, the incumbent managements, employees, and so on. In stead of segmenting LBOs into outsider-led LBOs and insider-led LBOs, this study only investigates LIBOs and LMBOs. This segmentation avoids the subjective judgement of the nature of initiators of LBOs, but it still accounts for most of the outsider-led LBOs and insider-led LBOs.

${ }^{5}$ Halpern et al (1999) argue that the incentives behind insider-led LBO and outsider-led LBO are different: insider-led LBOs usually face little takeover speculation with management wanting to take cash out of their firms by taking firms private. Outsider-led LBOs are usually are vulnerable to hostile takeover and they went private mainly due to the takeover interests. Moreover, the outside private investors will want to cash for their investment after the value of the asset has improved and they went private mainly due to takeover interests. However, it is important to note that Halpern et al (1999) do not empirically test the differences in value sources and motivations between inside-led LBOs and institution-led LBOs.
} 
Overall, Table 1.1 shows that the results for the three key working theories are periodspecific and sample-dependent. Moreover, the overheated LBO market conditions have great impacts on the applicability of the free cash flow hypothesis and the heterogeneity hypothesis (See Chapter 4, 5, 6 \& 7 for more discussions).

The key empirical results for each subtopic of this study are described below. How these findings support or fail to support the three key working theories is also briefly explained.

\section{Subtopic 1: Changing LBO Deal Characteristics}

This study finds significant differences in LMBO deal characteristics among the three sub periods (namely, 1985-1989, 1990-1999, and 2000-2005). In contrast, the overall deal characteristics of LIBOs remain unchanged over time, except that deal size of LIBOs over the sub period 2000-2005 is significantly larger than before. By further exploring the changes in LMBO characteristics over the period 1985-2005, this study finds little difference in overall LMBO deal characteristics between 2000-2005 and 1985-1989 (when the LBO market was overheated). Moreover, LMBOs in these two sub periods were in worse financial conditions than in the 1990s. Over the sub period 2000-2005, this study discovers that compared to LIBOs, higher premiums were paid for LMBOs, despite that they were in less attractive financial conditions. Combined, the above findings imply that the LMBO market was overheated over the sub period 2000-2005. 


\section{Subtopic 2: Factors Explaining LBO Premiums}

LBO transactions create significant wealth gains for target firms' stockholders, as the shareholders who sell their shares to acquirers typically receive premiums of $30 \%$ to $40 \%$. Interestingly, this study finds that the premiums for LMBOs over the sub periods 1985-1989 and 2000-2005 are not significantly different, while LMBO premiums during these two sub periods are both significantly higher than in the 1990s. This finding of aggressive pricing for LMBO deals over the sub period 2000-2005 is consistent with the overheated market hypothesis.

This study also finds different sets of factors explaining LBO premiums over the three different sub periods as follows:

1) Over the sub period 1985-1989, this study finds a nonlinear relationship between the pre-buyout level of free cash flow and LMBO premium. This finding implies an irrational market phenomenon where higher prices were paid for LMBOs with lower pre-buyout levels of free cash flows.

2) Over the sub period $1990-1999$, this study finds the same sets of factors explaining LBO premiums for both LIBOs and LMBOs. Most of the identified factors of LBO premiums represent the free cash flow hypothesis.

3) Over the sub period 2000-2005, this study finds different sets of variables explaining the premiums of LIBOs and LMBOs. Particularly, debt financing was used by acquirers of LIBOs and LMBOs in opposite ways. Institutions (initiators of LIBOs) adjusted premiums down when employing more debt financing (which normally leads to higher financial bankruptcy costs). In contrast, LMBO premiums were pushed higher by greater 
percentage of assumed debt financing. This finding implies that the rise of LMBO premiums may be driven by too much debt financing available in $2000-2005$.

In summarizing the above results from a value source related theory perspective, this study finds that when the buyout market was not overheated in the 1990s, the FCF hypothesis holds for both LIBOs and LMBOs. However, when the LBO market was overheated over the sub period 2000-2005, the LBO populations were heterogeneous and the FCF hypothesis holds only for LIBOs.

\section{Subtopic 3: Factors Explaining the Likelihood of Firms' Going Private via LBOs}

Subtopic 3 explores the motivations behind firms' going private via LBOs. Most of the findings are consistent with the results for Subtopic 2 in terms of the conclusions for the three working theories. Regarding the research methodology in this research area, this study finds an important advantage of conditional logistic regression over standard logistic regression: Conditional logistic regression is more powerful than standard logistic regression (used by most of the previous studies) in identifying the factors explaining the likelihood of firms' going private via LBOs (See Section 2.2.4 and Section 6.3 for details).

When the empirical results for the above three subtopics are combined, the following underlying story emerges: In the 1990s, when LBO markets cooled off, the value sources and motivations of both LIBOs and LMBOs can be explained by the free cash flow hypothesis. However, as the LBO market has overheated in recent years, fundamental 
financial prospects of some LMBOs do not justify the premiums and the motivations of these firms undertaking LMBOs. At the same time, LMBO deal characteristics over the sub period 2000-2005 differed greatly from the 1990s, and resembled those in the late 1980s when the market was also overheated. Further exploration of the overheated market phenomenon attributes to the fact that there is availability of too much debt financing and a relaxation of lenders' terms and conditions on debt financing in recent years (See Appendix A for details).

\section{Contributions}

Overall, this study achieves the following major contributions: First, the results of this study provide strong evidence that the LMBO market in the U.S. was overheated over the sub period 2000-2005. This conclusion undoubtedly provides great implications for both researchers and market participants. Second, to our best knowledge, this study is the first in LBO literature to suggest that the applicability of both the free cash flow hypothesis and the heterogeneity hypothesis is dependent on whether the buyout market is overheated. Thus, the findings of the previous studies based on the LBOs in the 1980s cannot be generalized across the later periods due to this dependency. Third, unlike previous studies that consider LBOs as homogenous irrespective of the type of initiators, this study improves the testing of specific hypotheses by taking into account the hypothesized differences between LMBOs and LIBOs. Last but not least, unlike previous

literature that effectively ignores matching sample challenges, this study is the first in LBO literature that adopts the proper statistical method to deal with a 1-1 matched case control sampling. 
The reminder of this thesis is organized as follows. Chapter 2 provides the comprehensive literature review of the existing literature. Chapter 3 presents the sample and discusses hypothesis development and research methodology for each subtopic of this study. Chapter $4,5, \& 6$ describe the empirical results for the three subtopics including 1) Changes in deal characteristics of U.S. LIBOs and LMBOs over time; 2) Factors explaining the premiums in LIBOs and LMBOs in the U.S.; 3) Factors explaining the likelihood of firms going private via LIBOs and LMBOs in the U.S. The implications for the three key working theories (namely, the free cash flow hypothesis, the overheated market hypothesis, and the heterogeneity hypothesis) are briefly discussed in Chapter 4, 5 \& 6 as well. Chapter 7 summarizes all the main empirical findings and the conclusions for the three key working theories. Finally, Chapter 8 outlines the major contributions of this study, summarizes its limitations, and provides recommendations for future research. 


\section{CHAPTER 2: LITERATURE REVIEW}

This chapter first explains the three key working theories of this study, namely, the free cash flow hypothesis, the overheated market hypothesis, and the heterogeneity hypothesis. The market undervaluation hypothesis and the asymmetric information hypothesis are also briefly explained subsequently, since the results of this study provide additional insights into these two theories as well. This chapter then provides a detailed review of the existing LBO literature relevant to the three subtopics of this study including 1) Changes in deal characteristics of LBOs over time, 2) Factors explaining the premiums in LBOs; 3) Factors explaining the likelihood of firms going private via LBOs.

\subsection{Explanation of LBO Value Source related Theories}

This section begins with an introduction to two categories of value source related theories: value creation and value transfer. This section then provides a detailed explanation of the three key working theories (in 2.1.1) and two other theories (in 2.1.2). ${ }^{6}$

Theoretically, there are two categories of theories regarding the sources of value created throughout LBO transactions: 1) LBOs do create real value; and 2) LBOs just transfer value from the other parties (e.g. employees, bond holders, etc.) to the post-LBO shareholders. Arguments for value creation in LBOs include the free cash flow hypothesis (Jensen, 1986; Lehn \& Poulsen, 1989; Kaplan, 1989; Kaplan, 1991), the tax

\footnotetext{
${ }^{6}$ See Appendix F for an introduction to the value source related theories that are not included in Section 2.1
} 
advantage hypothesis (Lehn \& Poulsen, 1989; Kaplan, 1989), and the elimination of public reporting, exchange registration and listing expenses (Travlos \& Cornett, 1993). Among the above explanations, the reasons for the value increases in LBOs have been mainly attributed to the free cash flow hypothesis. Researchers arguing for value transfer in LBO transactions promote explanations like the asymmetric information hypothesis (Kaplan, 1989; Smith, 1990; Ofek, 1994), the employee-wealth-transfer hypothesis (Kaplan, 1988; Faludi, 1990), value transfer between bondholders and stockholders (Jensen, 1988; Asquith \& Wizman, 1990), value transfer among bondholders (Kaplan \& Stein, 1993), and trade-offs between the long-term and short-term gains (Kaplan, 1989; Maksimovic \& Titman, 1991).

\subsubsection{Three Key Working Theories of This Study}

Among the above value creation and value transfer explanations, this study mainly focuses on three key working theories, namely, the free cash flow hypothesis, the heterogeneity hypothesis, and the overheated market hypothesis.

Free Cash Flow Hypothesis: The free cash flow hypothesis, also called the reducedagency-cost hypothesis, argues that buyout companies previously invested in negative net present value (NPV) projects and thus reductions in (possibly negative NPV) capital expenditures post-LBO increased company profitability and value (Jensen, 1986). Jensen (1986) further demonstrates that the large debt-service payments incurred by LBO transactions undoubtedly forced managers to find ways to generate cash. More importantly, these transactions forced managers to disgorge the excess free cash flow that 
would otherwise be invested unwisely, resulting in reduction of the agency cost. Since public companies rarely have the incentive to do so, Jensen (1986) argues that in lowgrowth businesses, the public corporation is inferior as an organizational form to the LBO.

With regard to the free cash flow explanation of management-led buyouts, Green (1992) argues that there are at least four potential sources of value in a management-led buyout that can be deduced from the theoretical agency literature. First, managers are entitled to a higher fraction of profits generated, arising from increased efficiency. Second, ownermanagers can be expected to devote more effort to seeking out innovative projects (Jensen \& Meckling, 1976). Third, the concentration in the financial claims can be expected to enhance monitoring of post buy-out performance and managerial decisions. Lastly, the need to service and pay down debt reduces managerial discretion in the allocation of the free cash flows of the business.

Heterogeneity Hypothesis: Halpern et al (1999) indicate that LBO populations are heterogeneous in managerial ownership, and there are two types of poorly performing firms that go private through LBOs: 1) A group of firms in which managers own an insignificant fraction of their firm's stock and are vulnerable to hostile takeover; 2) A group of firms in which managers own a significant fraction of their firm's stock and face little risk of hostile takeover. As noted earlier, this study extends Halpern et al (1999)'s idea of the heterogeneity hypothesis as LBOs being heterogeneous in the type of initiators. Particularly, the heterogeneity hypothesis of this study assumes that LIBOs 
have different deal characteristics, value sources, and motivations than LMBOs.

Overheated Market Hypothesis: Kaplan and Stein (1993) define an overheated LBO market as a demand push from the public junk bond market resulting in LBOs to be more aggressively priced and more susceptible to costly financial distress. They further attribute the abrupt rise and decline of U.S. LBOs in the 1980 s to the overheated market hypothesis. Kaplan and Stein (1993) note that buyout volume rose from less than $\$ 1$ billion in 1980 to a peak of more than $\$ 60$ billion in 1988 , and then fell dramatically, to less than $\$ 4$ billion in 1990 , demonstrating that the market had been overheated during the late 1980's. See Section 2.2.1 for a detailed review of the study by Kaplan and Stein (1993).

\subsubsection{Two additional Working Theories of This Study}

Two additional LBO value source related theories, the asymmetric information hypothesis and the market undervaluation hypothesis, are described as follows.

Asymmetric Information Hypothesis: Management, as an informed party, is assumed to have better information about the value of firm. The asymmetric information hypothesis thus assumes that management may put the other potential stakeholders who do not know the real value of LBO firms (i.e. debt holders and public investors) at a disadvantage when they take firms private via LBOs. In other words, management may intentionally lower the buyout price by not telling the "correct value" of the firm. DeAngelo et al 
(1984) conclude that the principal criticism leveled against management-led buyout is based on the absence of arms-length negotiation between management as a purchaser of the public stock interest and management as a selling agent for public stockholders. Lee et al (1992) indicate that the nature of these management-led buyout transactions inherently provides for conflicts of interest. While management, as potential owners of the LBO firm, has the fiduciary obligation to obtain the highest price for shareholders, it also has an incentive to make an acquisition at the lowest possible price. This conflict is more pronounced when the entire firm is taken private via LBO, because the firm's top management is generally part of the buyout group. Note that this study only tests whether the premiums in LMBOs are lower than in LIBOs, and thus whether the managers benefit due to their asymmetric information by deliberately lowering the price.

Market Undervaluation Hypothesis: In practice, most of the managers regard low P/E (representing undervaluation of LBO targets) as the most important reason for taking their firms private (Maupin et al, 1984). However, the market undervaluation possibility is rarely examined by the previous LBO literature. The theoretical foundation of market undervaluation hypothesis is that the market value might reflect all publicly available information, but not management's private information about the future prospects of the company in the presence of information asymmetry. Thus, there is a possibility that the company's stock is being undervalued by the stock market. The market undervaluation hypothesis assumes that the more an LBO target is undervalued prior to the buyout, the more premiums would be paid to take it private or it has more chances of going private via $\mathrm{LBO}$. 


\subsection{Literature Review on Three Subtopics of This Study}

This section provides a review of the literature relevant to the three subtopics of this study, with special attention paid to how each of the working theories are tested by various researchers within each subtopic. ${ }^{7}$

\subsubsection{Literature Review on Changes in LBO Deal Characteristics}

The first subtopic this study attempts to explore is how LBO deal characteristics have changed over the period 1985-2005. The main purpose of researching this subtopic is that the results can provide implications for the applicability of the overheated market hypothesis to the recent LBO market. The central paper on the overheated market hypothesis, the work by Kaplan and Stein (1993), points out that LBO deal characteristics had greatly changed in the 1980s and the buyout market was overheated in the late 1980s. This section thus provides an examination of the work by Kaplan and Stein (1993). ${ }^{8}$

Based on the analysis of 124 large MBOs completed over the period 1980-1989, Kaplan and Stein (1993) conclude that the LBO market in the late 1980s was overheated. ${ }^{9}$ They use nonparametric rank tests to compare the values of the firm-specific and deal-specific

\footnotetext{
${ }^{7}$ In addition to these three subtopics, there are four other research subtopics in the existing LBO literature that also shed some light upon the three key working theories of this study. These four research subtopics include 1) Post-LBO firms' operating performance improvement after LBO transactions; 2) Reverse-LBO firms' performance; 3) Re-LBO firms' performance; 4) Deal structure of LBO transactions. A brief review of the main papers on these four subtopics is provided in Appendix E.

This is the only existing study identified relevant to Subtopic 1.

9 LMBO defined in the study is slightly different than MBO defined by Kaplan and Stein (1993). This study requires the leading role of management for a LBO to be considered as LMBO. However, Kaplan and Stein (1993) classify LBOs with the participation of management as MBOs. It is important to note that management-led LBOs and LBOs with the participation of management could have different degree of asymmetric information and incentives. For example, faced with hostile takeover attempt, management in the target firm may choose to participate in an LBO, though they may not play a leading role.
} 
variables (see below) in three distinct sub periods: 1980 to 1982 (or the "early 1980 s"), 1982 to 1985 (or the "mid-1980s"), and 1986 to 1989 (or the "late 1980s"). They use three categories of data to judge whether the LBO market is overheated:

1) The overall price paid to take the company private. They find that multipliers proxied by price/cash flow rose in the 1980s. Also, they find prices to be particularly high in deals financed with junk bonds. In their study, buyout price is measured as sum of the market value paid for the firm's equity, the value of the firm's outstanding debt, and the fees paid in the transaction, less any cash removed from the firm to finance the buyout. Cash flow is measured as EBITDA less capital expenditures.

2) Buyout capital structure and risk. They find that the MBOs in the late 1980s had significantly more risk than those in the mid-1980s and with somewhat higher leverage ratios. Risk is measured as the standard deviation of the growth rate of operating margins calculated from at least six years and up to ten years of pre-buyout financial data. They also find that public junk bond financing started to replace private subordinated debt in the mid 1980s. Moreover, prices for LBOs were particularly high in deals financed with these junk bonds.

3) Incentives of buyout investors. They find a significant upward trend in total deal feestransaction value ratio in the 1980s. This finding implies that banks have more incentives to finance LBO deals in the late 1980s, as they were better compensated in LBO transactions.

In terms of future research, Kaplan and Stein (1993) and other researchers including Bae and Hoje (2002) and Allen (1996) all call for a comparison of LBO deal characteristics 
between the 1990 s and the 1980 s. There are also predictions or comments regarding the possible differences between the LBOs completed in the 1990s and those in the 1980s: Kaplan and Stein (1993) believe that future LBOs may follow the course of earlier 1980s' deals; Allen (1996) states that the LBO market moved to high-growth, technology-driven industries during the 1990s, while most LBOs in the 1980s took place in mature, slowgrowing industries; Jin and Wang (2002) indicate that the source of profitability was due to the financial inefficiency in the $1980 \mathrm{~s}$, but shifted more towards strategic inefficiency in the 1990s, thus the skills required for success are different from those in the 1980s. They also state that there may be few LBO target firms in good financial condition in the 90s compared to the 80s; Eddey, Lee, and Taylor (1996) state the possibility that goingprivate transactions are time-specific, with the precise context varying from one period to another. $^{10}$

\subsubsection{Literature Review on Premiums Paid to Shareholders of LBOs and the Explanatory Factors}

There are three main papers (the work by Lehn and Poulsen (1989), Kieschinick (1998), and Halpern et al (1999)) that explore factors explaining LBO premiums. ${ }^{11}$ Among these three studies, Lehn and Poulsen (1989) and Kieschinick (1998) mainly focus on the free cash flow hypothesis, while Halpern et al (1999) explores the heterogeneity hypothesis.

\footnotetext{
${ }^{10}$ Some of the above comments are tested by this study and the corresponding results are provided in Chapter 4,5 \& 6 . 11 Note that there is another group of research examining the cumulative abnormal returns (CARs) around the announcement date of LBOs by adopting event study methodology. This is not covered by this study. However, to avoid omission of any potential variables that may affect the premiums paid to shareholders of LBOs, this study also reviews some of the studies examining the determinants of the CARs around LBO announcement. However, there aren't any additional variables identified, so the review of these studies is not included.
} 
In the following, the definitions of LBO premiums used by the previous research are first introduced. A review of the three previous studies is then provided, followed by a summary of the empirical findings on the factors explaining LBO premiums (presented in Table 2.1). At the end of this section, a summary of the implications for the three working theories is provided, along with a brief discussion of the limitations of the previous studies.

All three papers use LBO premiums as dependent variable, but the calculation of LBO premiums varies slightly based on the length of pre-LBO period. Lehn and Poulsen (1989) and Kieschinick (1998) calculate the average premiums paid in LBOs as the nonmarket-adjusted return from 20 trading days immediately preceding the LBO announcement to the final price at which the firm's common equity traded. ${ }^{12}$ Halpern et al (1999) use a shorter pre-sale period, computing the premiums as total returns from 1 week prior to LBO announcement to the final price.

The seminal paper on factors explaining premiums paid to shareholders of LBOs, Lehn and Poulsen (1989) examine a sample of 263 going private transactions over the period 1980-1987. Note that they use public-to-private transactions interchangeably with leveraged buyouts (See Appendix C for details). Thus one limitation of their study lies in their inaccurate definition of LBO. In terms of variable selection, they choose CF/EQ (cash flow scaled by firm size ${ }^{13}$ ), TAXEQ (tax liability scaled by firm size), and

\footnotetext{
${ }^{12}$ They admit that some of the premium may be paid to stockholders before the final trading day and thus the final price will not represent the full premiums in some two-tier tend offer.

${ }^{13}$ It is important to note that firm size, in this study, only indicates the market value of LBO firms during the pre-LBO period. It is proxied by the market value of LBO target firms one year prior to announcement date of LBO.
} 
SALESGR5 (the average annual percentage increase in net sales during the five years preceding the going private transaction) as independent variables to estimate LBO premiums in OLS regression. The cash flow in their study is defined as operating income before depreciation minus total income taxes, minus interest expense on short- and longterm debt, minus preferred dividends, and minus common dividends (See the following Kieschinick (1998)'s discussion of the flaw in this proxy). They separate their sample according to the percentage of management holdings as a proxy for the severity of potential agency problems. They also divide the full sample into two sub-samples consisting of going-private transactions from 1980-1983 and from 1984-1987.

Generally, Lehn and Poulsen (1989)'s results support the FCF hypothesis: Over the entire sample, they find that $\mathrm{CF} / \mathrm{EQ}$ is the only significant factor. After dividing the full sample into two sub-samples based on time period, they find that the FCF hypothesis only holds for the full sample over the sub period 1984-1987. Since the threat of a hostile takeover was greater during this period, they explain this finding as managers may want to pay more for excess cash flows if their firms were more likely targets of hostile takeover attempts. By dividing the full sample based on managerial ownership, they find that the FCF hypothesis only holds for firms whose managers owned relatively little equity before the going private transactions over the entire period 1980-1987. They thus conclude that the FCF hypothesis holds better for firms with higher agency costs (represented by lower managerial ownership). Overall, these findings lead them to conclude that the free cash flow hypothesis explains the cross-sectional variation in premiums paid to shareholders of LBOs. 
Kieschinick (1998) reexamines Lehn and Poulsen (1989)'s sample and finds that firm size and potential tax expenditures are two significant explanatory factors for LBO premiums over the period 1980-1987. However, he does not find the firm's pre-buyout level of free cash flow (without being scaled) to be a significant factor for LBO premiums. He further points out that Lehn and Poulsen (1989)'s specification of their free cash flow variable is misleading. First, he argues that CF/EQ used by Lehn and Poulsen (1989) compounds a number of potential influences on the premiums paid in a going private transaction (e.g. the level of the free cash flows, firm size, the firm's use of financial leverage, the market's expectations about firm's future performance, etc.). Second, he finds that the greater the firm's market value of equity (EQ), the smaller the premium paid to take it private. Thus, CF/EQ would have a significant positive coefficient, though $\mathrm{CF}$ appears to have an insignificant coefficient when entered as a separate regressor. Overall, his results, based on the same LBO sample as Lehn and Poulsen (1989)'s, fail to support the FCF hypothesis. It is important to note that Kieschinick (1998)'s different results suggest the selection of proxy for the free cash flow variable has great effects on null-hypothesis testing.

Halpern et al (1999) examine 126 completed LBOs that effected during the period 19811986. They find that the mixed evidence of previous studies arises from the fact that the population of LBO is heterogeneous and there are actually two types of poorly performing firms that go private through LBOs.

1) Firms in which managers own an insignificant fraction of their firm's stock and are vulnerable to hostile takeover. 
2) Firms in which managers own a significant fraction of their firm's stock and face little risk of hostile takeover.

They further argue that motivations for the above two types of firms are different. Type-1 firms are usually led by outside private investors who will want to cash in their investment after the value of the assets has improved. In this case, the decision to undertake LBO is mainly due to takeover interests. In contrast, type-2 firm LBOs are usually led by management which go private mainly because management wants to take cash out of their firms. This also concentrates their residual claims on the post-LBO firm.

It is important to note that their empirical results do not completely support the above relationships between the level of pre-buyout managerial ownership and initiator type for type-1 firms. They find that almost half of Type-1 firms (35 out of 76 type-1 firms) were still led by insiders, instead of outside private investors as they argue. Unfortunately, they do not further classify LBO firms according to the initiators of LBOs in their analysis, even though they point out the different incentives between insider-led LBOs and thirdparty-led LBOs. Thus, Halpern et al (1999)'s classification of LBOs in managerial ownership may not fully reflect different motivations between insider-led LBOs and outside-led LBOs.

The heterogeneity hypothesis of Halpern et al (1999) also assumes that the premiums paid for LBOs will be influenced by the potential for improved firm performance, rather than just the sufficiency of free cash flow as the free cash flow argues. To proxy for firm 
potential for improved performance, Halpern et al (1999) use the firms' prior relative stock performance (firm stock performance relative to S\&P 1 year prior to $\mathrm{LBO}$ announcement). Halpern et al (1999) use this stock performance variable in addition to Tobin's Q, since they argue, “The market makes assessments of how the firm's competitive problems influence its future performance and these ex ante assessments are impounded in Tobin's Q. Nevertheless, unless one is willing to assume that the market makes perfect assessments of these problems, then their severity will be revealed over time by the firm's competitive behavior and captured in its stock price movements. Consequently, the more sever the firm's competitive problems, the poorer the firm's stock performance is expected to be over time relative to the market". However, the firms' prior relative stock performance may not be an accurate proxy for firms' potential for improved performance, since, in the short run, stock prices often deviate from the fundamental values due to incomplete information about future earnings and market sentiment (Black, 1986; De Long et al, 1990; Myers \& Majluf, 1984).

Halpern et al (1999) present two equations to compare the corresponding two working theories: the free cash flow hypothesis and the heterogeneity hypothesis. To explore the free cash flow hypothesis, they include pre-buyout tax expenditures, free cash flow (both scaled by firm's net sales), a dummy variable to measure bidder competition, and the interaction of free cash flow with managerial ownership. They measure a firm's free cash flows as its operating income before depreciation, minus its total income taxes adjusted for the change in deferred taxes, minus its cash dividends to common and preferred stock holders, and minus net common stock repurchases. 
Premiums $($ FCF hypothesis $)=$ constant + Bidder competition + Tax expenditures + Free cash flows + (Managerial stock ownership)* (Free cash flows).

To explore the heterogeneity hypothesis, they remove the free cash flow variable and add the interaction of prior stock performance and square of managerial ownership, prior stock performance (as proxy for firms' potential for improved performance), in addition to common variables tax expenditures and bidder competition.

Premiums (heterogeneity hypothesis) $=$ constant + Bidder competition + Tax expenditures + Prior stock performance + (Managerial stock ownership)* (Prior stock performance $)+(\text { Managerial stock ownership })^{2} *$ (Prior stock performance) .

They find significant coefficient for the interaction of prior stock performance with square of managerial ownership in the equation representing the heterogeneity hypothesis. This finding implies that at both the low end of prior managerial ownership and the high end of prior managerial ownership, the poorer the prior stock performance, the higher the premiums paid to shareholders of LBOs. Moreover, Halpern et al (1999) further find that the equation representing the heterogeneity hypothesis explains significantly more of the variation in LBO premiums than other estimate equations which represent the FCF hypothesis but ignore the heterogeneity hypothesis (e.g. Kaplan, 1989; Lehn \& Poulsen, 1989). In contrast, the equation representing the FCF hypothesis in their study does not yield significant results, even though the coefficient on the interaction between managerial equity and the firm's free cash flow is significant. Based on these empirical results, Halpern et al (1999) conclude that prior evidence is based on incorrectly specified statistical tests, which explains why previous evidence on the free cash flow hypothesis has been mixed. 
To summarize the empirical findings of the above three studies, the results for factors explaining LBO premiums are presented in Table 2.1.

Table 2.1: Results for Explanatory Factors of the Premiums Paid to Shareholders of LBOs

\begin{tabular}{|c|c|c|c|c|}
\hline $\begin{array}{l}\text { Explanatory } \\
\text { Factor }\end{array}$ & $\begin{array}{l}\text { Hypothesized } \\
\text { Sign }\end{array}$ & $\begin{array}{l}\text { Relation with } \\
\text { Premiums }\end{array}$ & Reference & Proxy \\
\hline \multirow[t]{3}{*}{ Free cash flow } & \multirow[t]{3}{*}{+} & + Significant & $\begin{array}{l}\text { Lehn and Poulsen } \\
\text { (1989) }\end{array}$ & CF/EQ \\
\hline & & \multirow[t]{2}{*}{ + Insignificant } & Kieschinick (1989) & $\mathrm{CF}^{14}$ \\
\hline & & & Halpern et al (1999) & Free Cash Flow/Net Sales \\
\hline Growth rate & - & + Insignificant & $\begin{array}{l}\text { Lehn and Poulsen } \\
\text { (1989) }\end{array}$ & SALESGR5 \\
\hline $\begin{array}{l}\text { Prior } \\
\text { performance }\end{array}$ & - & -Significant & Halpern et al (1999) & $\begin{array}{l}\text { Ratio of stock performance } \\
\text { relative to S\&P }\end{array}$ \\
\hline $\begin{array}{l}\text { Bidder } \\
\text { competition }\end{array}$ & + & + Insignificant & Halpern et al (1999) & A dummy variable \\
\hline $\begin{array}{l}\text { Managerial } \\
\text { ownership }\end{array}$ & Nonlinear & $\begin{array}{l}\text { Significant } \\
\text { nonlinear } \\
\text { relationship }\end{array}$ & Halpern et al (1999) & $\begin{array}{l}\text { Percentage of voting stock } \\
\text { held by officers and } \\
\text { directors of the company }\end{array}$ \\
\hline Firm Size & - & -Significant & Kieschnick (1998) & $\begin{array}{l}\text { Market value of LBO target } \\
\text { firms one year prior to LBO } \\
\text { announcement }\end{array}$ \\
\hline \multirow[t]{4}{*}{ Tax } & \multirow[t]{4}{*}{+} & $\begin{array}{l}\text { + Insignificant } \\
\text { (1984-1987) }\end{array}$ & $\begin{array}{l}\text { Lehn and Poulsen } \\
\text { (1989) }\end{array}$ & $\begin{array}{l}\text { (Tax expenditures-deferred } \\
\text { tax)/Market value of Equity }\end{array}$ \\
\hline & & \multirow[t]{2}{*}{$\begin{array}{l}\text { - Insignificant } \\
(1980-1983)\end{array}$} & $\begin{array}{l}\text { Lehn and Poulsen } \\
(1989)\end{array}$ & $\begin{array}{l}\text { (Tax expenditures-deferred } \\
\text { tax)/Market value of Equity }\end{array}$ \\
\hline & & & Halpern et al (1999) & $\begin{array}{l}\text { (Tax expenditures-deferred } \\
\text { tax)/Net Sales }\end{array}$ \\
\hline & & + Significant & Kieschnick (1998) & $\begin{array}{l}\text { Tax expenditures-deferred } \\
\text { tax (without adjusted for } \\
\text { firm size) }\end{array}$ \\
\hline
\end{tabular}

Implications for the two theories (namely, the free cash flow hypothesis and the heterogeneity hypothesis) are summarized as follows, along with a discussion of the limitations of the previous studies.

\footnotetext{
${ }^{14}$ Kieschinick (1989) use the same measures for free cash flow as Lehn and Poulsen (1989), so this study uses CF to refer to this measure.
} 
Free Cash Flow Hypothesis: Table 2.1 shows that the mixed findings in this research area focus on the free cash flow hypothesis: Kieschinick (1989) and Halpern et al (1999)'s results fail to support the FCF hypothesis, while Lehn and Poulsen (1989)'s findings provide support for it. However, different studies use different proxies to measure pre-buyout free cash flow of LBO targets, which may have great impacts on their results. For example, Lehn and Poulsen (1989) use firm's market value of equity to scale the free cash flow variable, but Kieschinick (1989) argues that firm's market value of equity is negatively related to LBO premium, which affects Lehn and Poulsen (1989)'s results for the FCF hypothesis. Thus, the main issue for testing the free cash flow hypothesis focuses on choosing the proper measure for the pre-buyout free cash flow.

Heterogeneity Hypothesis: In terms of Halpern et al (1999)'s heterogeneity hypothesis, as discussed earlier, firms' prior relative stock performance used in their study may not be an accurate proxy for firms' potential for improved performance. Another limitation of the work by Halpern et al (1999) is that they do not separate insider-led LBOs from outsider-led LBOs, though they argue that these two types of firms go private for different incentives.

Regarding the overheated market hypothesis, most of the previous studies ignore the impact of the overheated buyout market in the late 1980s on the null hypothesis testing, except Kieschinick (1989) argues that the insignificant coefficient on the free cash flow variable identified in his study could be subjected to the overheated market explanation. In other words, the conclusions of the above studies for the FCF hypothesis and the 
heterogeneity hypothesis are made based on the assumption that the buyout market conditions have no impact on the value sources of LBOs. ${ }^{15}$

\subsubsection{Literature Review on Factors Explaining the Likelihood of Firms' Going Private via LIBOs or LMBOs}

This section reviews the previous literature on factors explaining the likelihood of firms' going private via LIBOs or LMBOs. Maupin et al. (1984), Lehn and Poulsen (1989), Opler and Titman (1993), Kieschnick (1998), and Halpern et al (1999) are five main studies exploring what pre-transaction firm characteristics are related to the likelihood of firms' going private via LBOs. Among these five studies, Maupin et al. (1984) is the only one that examines only management-led buyouts. From the working theory perspective, the free cash flow hypothesis and the heterogeneity hypothesis are mainly tested by these five studies within each subtopic: The results of work by Maupin et al. (1984), Lehn and Poulsen (1989), Opler and Titman (1993), and Kieschnick (1998) provide implications for the free cash flow hypothesis. The research by Halpern et al (1999) provides support for the heterogeneity hypothesis.

This section begins with a brief review of these studies with a focus on their variable selection approach. Since some of these studies (including work by Lehn and Poulsen (1989), Kieschnick (1998), and Halpern et al (1999)) also explore Subtopic 2, this section does not discuss the proxies for the variables that are already covered in Section 2.2.2. Then, the implications for the free cash flow hypothesis and the heterogeneity hypothesis

\footnotetext{
${ }^{15}$ Unfortunately, this assumption is not true, as this study finds that the applicability of both the free cash flow hypothesis and the heterogeneity hypothesis to LBOs is affected by the overheated LBO market conditions.
} 
are briefly summarized. Since the matching between sampling method and statistical method is one of the main issues in this research area and since most of the previous studies fail to use appropriate statistical methods, more details and implications of these assumptions are provided in the following section (namely, Section 2.2.4).

Maupin et al (1984) study the overall differences in pre-buyout firm characteristics between MBO targets and firms that remain public by selecting 25 financial ratios. These ratios are taken through phone surveys of financial offers of MBOs over the period 19721983 and from relevant literature review. Through variable reduction by discriminant analysis, five ratios are identified as the most significant in distinguishing publicly traded firms and firms that go private via MBOs. Maupin et al (1984) find firms that undertook MBOs tend to have higher concentration of ownership, higher cash flow to net worth, higher cash flow to total assets, lower price/book value ratio, and higher dividend yield. Cash flow in their study is defined as net income plus depreciation, depletion, and amortization. However, their proxy for free cash flow is misleading since it does not exclude cash dividends (See below for further discussion). Moreover, they find that the going private firms are characterized by both higher prior undistributed cash flows (including dividends) and higher cash dividends. Thus, their research does exclude the possibility that the identified effect of free cash flow on the odds of the firms' undertaking LBOs is affected by the effect of cash dividends. ${ }^{16}$

Lehn and Poulsen (1989) select undistributed free cash flow and growth prospect as

\footnotetext{
${ }^{16}$ To remove the potential effect of cash dividends on the free cash flow hypothesis testing, this study excludes cash dividends from the measure of pre-buyout free cash flow variable of this study.
} 
independent variables under the free cash flow hypothesis, and include the takeover speculations and tax expenditures as control variables. Growth prospect in their study is proxied by SALESGR5 (the average annual percentage increase in net sales during the five years preceding the going private transaction). Based on a sample of 263 going private transactions over the period 1980-1987, they find a significant and positive coefficient on undistributed cash flow and a significant and negative coefficient on growth prospects (See Section 2.2.2 for the discussion of the flaw in their proxy for prebuyout free cash flow). However, Kieschnick (1998) reexamines Lehn and Poulsen (1989)'s data. He does not find undistributed cash flow as a significant factor using a different statistical method. He further points out a bias with Lehn and Poulsen (1989)'s statistical method (See Section 2.2.4 for details).

Unlike Lehn and Poulsen (1989) and Kieschnick (1998) that focus only on the incentives of firms' going private via LBOs, Opler and Titman (1993) take financial distress costs into consideration. They attempt to distinguish the importance of incentives such as tax savings and reductions of agency costs for LBOs from the importance of financial distress cost deterrent to LBOs. To test the free cash flow hypothesis, they select variables including free cash flow, the interaction of Tobin's $Q$ and free cash flow, and the interaction of Tobin's $Q$ with diversification index. ${ }^{17}$ They indicate that in contrast to the free cash flow theory, the financial distress costs theory does not imply that the interaction between Tobin's $Q$ and free cash flow is important. Thus the significance of coefficient on this interaction term will indicate that the free cash flow hypothesis holds,

\footnotetext{
17 They construct a Herfindahl index which accounts for the distribution of the firm's employees across SIC codes to empirically measure diversification.
} 
rather than the financial distress costs theory. They use operating income scaled by firms' assets to proxy for firms' pre-buyout level of free cash flow. However, Halpern et al (1999) argue that Opler and Titman (1993)'s measure of LBO target's pre-buyout free cash flow is misleading due to their inclusion of the cash dividends. ${ }^{18}$ To test the effect of financial distress costs, Opler and Titman (1993) select variables such as product uniqueness and financial distress costs (proxied by assets and integration index). They also include Tobin's $Q$ and diversification index that can be explained by both theories. ${ }^{19}$ Overall, Opler and Titman (1993)'s findings support the idea that both potential financial distress costs and free cash flow problems can explain the likelihood of firms' going private via LBOs. Consistent with the free cash flow hypothesis, they find that LBOs can be characterized as having a combination of unfavorable investment opportunities (low Tobin's Q) and relatively high pre-buyout free cash flows, though they find that neither the free cash flow nor Tobin's $Q$ influence the decision to go private.

Halpern et al (1999) examine LBOs that took place during the period 1981-1986 to test the heterogeneity hypothesis. To test the free cash flow hypothesis, they include variables such as free cash flow, leverage ratio, tax expenditures, investment expenditures, and profitable reinvestment opportunities (proxied by Tobin's Q). To test the heterogeneity hypothesis, they include managerial ownership and prior relative stock performance. Tax expenditures, managerial ownership, and prior relative stock performance are indentified

\footnotetext{
${ }^{18}$ Halpern et al (1999) give an example to illustrate this reasoning: Consider two firms that are alike in their poor investment prospects and possess the same net operating cash flow. Firm A distributes those cash flows as cash dividends, but firm B reinvests them in operations. Clearly firm B is incurring the higher agency costs associated with its free cash flows, but this would be missed under the net operating cash flow measure.

${ }^{19}$ Opler and Titman (1993) argue that on one hand, Tobin's q may proxy for the reinvestment opportunities. On the other hand, it can also proxy for the cost of taking on debt since firms with high Tobin's q typically have less collateralize assets and greater growth opportunities. They also argue that diversification index can proxy for both good asset utilization (incentive realignment theory) and direct financial distress costs (financial distress theory).
} 
as the factors explaining the likelihood of firms' going private via LBOs. These findings provide support for Halpern et al (1999)'s heterogeneity hypothesis. Additionally, they compare two LBO clusters (LBOs with higher managerial ownership and LBOs with lower managerial ownership) with public firms separately. They find that managerial ownership is the only variable that has opposite signs in these two logistic regressions. This also implies that LBO population is heterogonous in managerial ownership.

To summarize the factors explaining the likelihood of firms' going private via LBOs, the empirical findings of the above five papers are presented in Table 2.2. 
Table 2.2: Results for Explanatory Factors of the Likelihood of Firms' Going Private via LBOs

\begin{tabular}{|c|c|c|c|c|}
\hline $\begin{array}{l}\text { Explanatory } \\
\text { Factor }\end{array}$ & $\begin{array}{l}\text { Hypot } \\
\text { hesize } \\
\text { d } \\
\text { Sign }\end{array}$ & $\begin{array}{l}\text { Relation with } \\
\text { the Likelihood } \\
\text { of Firms' } \\
\text { Going Private } \\
\text { via LBOs }\end{array}$ & Reference & Proxy \\
\hline \multirow[t]{6}{*}{$\begin{array}{l}\text { Undistribute } \\
\text { d cash flow }\end{array}$} & \multirow[t]{6}{*}{+} & \multirow[t]{2}{*}{+ Significant } & $\begin{array}{l}\text { Lehn and Poulsen } \\
(1989)\end{array}$ & $\mathrm{CF} / \mathrm{EQ}$ \\
\hline & & & Maupin et al (1984) & $\begin{array}{l}\text { Cash flow/ Net worth \& Cash flow/ Total } \\
\text { assets }\end{array}$ \\
\hline & & \multirow[t]{4}{*}{ + Insignificant } & Halpern et al (1999) & Free Cash Flow/Net sales \\
\hline & & & Kieschnick (1998) & CF/EQ \\
\hline & & & $\begin{array}{l}\text { Lehn and Poulsen } \\
(1989)\end{array}$ & $\mathrm{CF} / \mathrm{EQ}$ \\
\hline & & & $\begin{array}{l}\text { Opler and Titman } \\
\text { (1993) }\end{array}$ & Operating income/assets \\
\hline \multirow[t]{3}{*}{$\begin{array}{l}\text { Growth } \\
\text { prospects }\end{array}$} & \multirow[t]{3}{*}{-} & \multirow[t]{2}{*}{-Insignificant } & $\begin{array}{l}\text { Lehn and Poulsen } \\
\text { (1989) }\end{array}$ & SALESGR5 and SALESGR3 \\
\hline & & & Kieschnick (1998) & $\begin{array}{l}\text { SALESGR5, SALESGR4, SALESGR3, } \\
\text { SALESGR2 }\end{array}$ \\
\hline & & -Significant & $\begin{array}{l}\text { Lehn and Poulsen } \\
\text { (1989) }\end{array}$ & SALESGR4 and SALESGR2 \\
\hline \multirow{3}{*}{$\begin{array}{l}\text { Quality of } \\
\text { investment } \\
\text { opportunitie } \\
\text { s }\end{array}$} & \multirow[t]{3}{*}{-} & \multirow[t]{2}{*}{-Insignificant } & $\begin{array}{l}\text { Opler and Titman } \\
(1993)\end{array}$ & \multirow[t]{2}{*}{ Tobin's Q } \\
\hline & & & Halpern et al (1999) & \\
\hline & & -Significant & Maupin et al. (1984) & $\begin{array}{l}\text { P/B (Price of common stock/book value } \\
\text { per share) }\end{array}$ \\
\hline \multirow[t]{3}{*}{ Tax liability } & \multirow[t]{3}{*}{+} & \multirow[t]{2}{*}{+ Insignificant } & $\begin{array}{l}\text { Lehn and Poulsen } \\
\text { (1989) }\end{array}$ & $\begin{array}{l}\text { (Tax expenditures-deferred tax)/Market } \\
\text { value of Equity }\end{array}$ \\
\hline & & & Kieschnick (1998) & $\mathrm{Tax} / \mathrm{EQ}$ \\
\hline & & + Significant & Halpern et al (1999) & (Tax expenditures-deferred tax)/ Net sales \\
\hline \multirow{2}{*}{$\begin{array}{l}\text { Low cash } \\
\text { flow * high } \\
\text { Tobin's Q }\end{array}$} & \multirow[t]{2}{*}{-} & - Significant & \multirow{2}{*}{$\begin{array}{l}\text { Opler and Titman } \\
\text { (1993) }\end{array}$} & \multirow[t]{2}{*}{ Low cash flow * High Tobin's Q } \\
\hline & & - Insignificant & & \\
\hline \multirow[t]{3}{*}{$\begin{array}{l}\text { Takeover } \\
\text { threat }\end{array}$} & \multirow[t]{3}{*}{+} & \multirow[t]{3}{*}{ + Significant } & $\begin{array}{l}\text { Lehn and Poulsen } \\
(1989)\end{array}$ & \multirow{2}{*}{$\begin{array}{l}\text { Dummy variable FOOTSTEPS: } 1 \text { if the } \\
\text { firm received a competing bid or was the } \\
\text { subject of takeover speculation, and zero } \\
\text { otherwise. }\end{array}$} \\
\hline & & & Kieschnick (1998) & \\
\hline & & & Halpern et al (1999) & $\begin{array}{l}\text { Prior acquisition interest: } 1 \text { if there was } \\
\text { evidence in the WSJ index of interest in } \\
\text { acquiring the firm prior to the winning } \\
\text { bidder's first LBO announcement, } 0 \\
\text { otherwise. }\end{array}$ \\
\hline $\begin{array}{l}\text { High cash } \\
\text { flow * Low } \\
\text { Tobin's Q }\end{array}$ & + & + Significant & $\begin{array}{l}\text { Opler and Titman } \\
\text { (1993) }\end{array}$ & High cash flow * Low Tobin's Q \\
\hline $\begin{array}{l}\text { Dividend } \\
\text { yield }\end{array}$ & + & + Significant & Maupin et al (1984) & Dividend yield \\
\hline $\begin{array}{l}\text { Leverage } \\
\text { ratio }\end{array}$ & - & - Insignificant & Halpern et al (1999) & Leverage ratio \\
\hline $\begin{array}{l}\text { Investment } \\
\text { expenditures }\end{array}$ & - & - Insignificant & Halpern et al (1999) & Tobin's Q \\
\hline
\end{tabular}




\begin{tabular}{|c|c|c|c|c|}
\hline $\begin{array}{l}\text { Prior stock } \\
\text { performance }\end{array}$ & - & - Significant & Halpern et al (1999) & $\begin{array}{l}\text { The stock performance the firm relative } \\
\text { to the } S \& P 500 \text { over a year's period } \\
\text { ending } 1 \text { moth prior to the first indication } \\
\text { of takeover interest in the firm. }\end{array}$ \\
\hline \multirow[t]{2}{*}{$\begin{array}{l}\text { Managerial } \\
\text { ownership }\end{array}$} & \multirow[t]{2}{*}{-} & \multirow[t]{2}{*}{ + Significant } & Halpern et al (1999) & $\begin{array}{l}\text { The percentage of common stock held by } \\
\text { officers and directors prior to the LBO } \\
\text { announcement. }\end{array}$ \\
\hline & & & Maupin et al (1984) & $\begin{array}{l}\text { The concentration of ownership amongst } \\
\text { managers and directors }\end{array}$ \\
\hline \multirow{5}{*}{$\begin{array}{l}\text { Product } \\
\text { uniqueness }\end{array}$} & \multirow[t]{5}{*}{-} & \multirow[t]{2}{*}{ - Significant } & \multirow{5}{*}{$\begin{array}{l}\text { Opler and Titman } \\
\text { (1993) }\end{array}$} & Machinery industry dummy \\
\hline & & & & R\&D expense / Sales \\
\hline & & + Significant & & Selling expenses / Sales \\
\hline & & + Insignificant & & \\
\hline & & - Insignificant & & Machinery industry dummy \\
\hline \multirow{4}{*}{$\begin{array}{l}\text { Financial } \\
\text { distress } \\
\text { costs }\end{array}$} & \multirow[t]{4}{*}{-} & -Insignificant & \multirow{4}{*}{$\begin{array}{l}\text { Opler and Titman } \\
\text { (1993) }\end{array}$} & \multirow[t]{2}{*}{ Diversification index } \\
\hline & & + Significant & & \\
\hline & & -Insignificant & & \multirow[t]{2}{*}{ Log of assets } \\
\hline & & + Insignificant & & \\
\hline
\end{tabular}

The above five studies on factors explaining the likelihood of firms' going private via LBOs mainly explore two theories, the free cash flow hypothesis and the heterogeneity hypothesis. As within Suptopic 2, the overheated market hypothesis is not tested by the previous literature on the explanatory factors of the likelihood of firms' going private via LBOs. Implications for the free cash flow hypothesis and the heterogeneity hypothesis are summarized as follows.

Free Cash Flow Hypothesis: There are mixed findings on the free cash flow hypothesis. First, the findings of Lehn and Poulsen (1989) and Maupin et al (1984) on the undistributed free cash flow variable support the free cash flow hypothesis. However, the proxies they use to measure LBO target's pre-buyout free cash flow are misleading. For example, Maupin et al (1984) wrongly include the cash flow distributed to the other shareholders such as cash dividends. Moreover, Maupin et al (1984)'s results for the free cash flow variable may be misled by possibly high multicollinearity among their 
independent variables. ${ }^{20}$ Second, both Maupin et al (1984) and Halpern et al (1999) find a significantly positive relation between managerial ownership and the likelihood of firms' going private via LBOs. This finding fails to support the free cash flow hypothesis, as the free cash flow hypothesis regards that LBO target firms should have lower managerial ownership, thus higher agency costs. Third, there are mixed findings on Tobin's Q, a key variable to test the free cash flow hypothesis. Moreover, researchers argue that Tobin's Q could be subjected to different interpretations: Opler and Titman (1993) indicate that Tobin's $Q$ can not only proxy for both quality of investment opportunities, but also represent for low collateral, growth. Maupin et al (1984) interpret low Tobin's Q as undervaluation of stocks of LBO targets during pre-LBO period.

Heterogeneity Hypothesis: To test the heterogeneity hypothesis, Halpern et al (1999) include managerial ownership and prior relative stock performance. As shown in Table 2.2, tax expenditures, managerial ownership, and prior relative stock performance are identified as the factors explaining the likelihood of firms' going private via LBOs. These findings provide support for Halpern et al (1999)'s heterogeneity hypothesis, though, as discussed earlier, their proxy for firms' potential for improved performance (namely, firms' prior relative stock performance) is subjected to different interpretations.

\footnotetext{
${ }^{20}$ For example, LBO target firms tend to have higher free cash flow, if they pay higher tax prior to LBO announcement. Also, there may be a negative correlation between leverage ratio and tax expenditures, since firms can use more debt to shield tax.
} 


\subsubsection{Literature Review on Sampling Issue and Statistical Method}

The main methodological issues in the research area of explanatory factors of the likelihood of firms' going private via LBOs lie in sampling method and statistical method. It is important to match statistical method with sampling technique, since a mismatch between the two could greatly affect hypothesis testing and subsequent conclusions.

This section begins with a brief introduction to the related sampling designs (including random sampling, case-control sampling, semi-matched case-control sampling, and 1-1 matched case-control sampling) and statistical methods (including standard logistic regression and weighted maximum likelihood estimation). Then, the sampling methods and statistical methods employed by the previous research are summarized in Table 2.3 along with an evaluation of validity of statistical method in each study. This section ends with an introduction of conditional logistic regression, a proper statistical method for 1-1 matched case-control sampling design.

Sampling Methods: There are three sampling methods adopted by the previous literature in the research area of explanatory factors of the likelihood of firms' going private via LBOs: in specific, random sampling, semi-matched case-control sampling, and 1-1 matched case-control sampling. ${ }^{21}$ These sampling methods can be explained by the following examples: Consider the probability of the occurrence of a binary event, such as an LBO transaction, as an example. The random sampling approach is to take a single random sample from the population containing the binary variable (the event of LBO

\footnotetext{
${ }^{21}$ Note that "case-control" and "choice-based" sampling both refer to identical procedures; the former is used in the biometrics literature, the latter in econometrics and finance (Breslow, 1996).
} 
announcement). In contrast, case-control sampling design selects separate samples from two sub populations (such as LBOs and non-LBOs) with different sampling rates. ${ }^{22}$ The main advantage of case-control sampling over random sampling in this study is that random sampling would produce few LBOs in the control group, which contains little information and requires a large sample size to include enough LBO cases. Compared to case-control sampling design, 1-1 matched case-control sampling further matches each LBO with a single non-LBO on some basis such as similar industry and firm size. Semimatched case-control sampling have strata or pairings of case and controls that are nominally but not meaningful unique. For example, Lehn and Poulsen (1989), Kieschnick (1998), and Maupin et al (1984) adopt 1-1 matched case-control sample to match nonLBOs with LBOs by industry SIC code and firm size. Halpern et al (1999) use semimatched case-control sampling design by randomly selecting control firms in an equal number to the number of sample LBOs for a particular year. Overall, the main reason for introduction of matching into case-control sampling design is that matching can increase the statistical precision of the estimation by controlling industry effects, size effects, or economy-wide influences.

Based on the above explanations, the limitations of the previous research in terms of their sampling methods are briefly discussed as follows.

Opler and Titman (1993) use random sampling method. However, they only use a

\footnotetext{
${ }^{22}$ Specifically, in the context of LBO research, consider a population of $\mathrm{N}$ firms consisting of N1 LBOs and N2 nonLBOs. Suppose the desired sample size is $\mathrm{n}$. In the case of random sampling, $\mathrm{n}$ firms including both LBOs and control firms are drawn randomly from the entire population. Under choice-based sampling, $\mathrm{n} 1$ firms are randomly selected from the target subpopulation and $\mathrm{n} 2$ firms are selected from the non-target subpopulation (Palepu, 1986). Put another way, choice-based sampling takes a firm's probability of being selected as a function of its public status.
} 
particular year's financial data for their control firms, while their LBOs firms occurred in different years over the period 1980-1990. This sampling method can not control economy-wide influences represented by time comparability between cases and controls. Thus, this sampling design does not suit the nature of this study with a long study period (1985-2005), since the environment related to LBO market has changed significantly over the past 20 years (See Appendix A for details).

Halpern et al (1999) adopt semi-matching sampling method to randomly select control firms in an equal number to the number of sample LBOs for a particular year. However, the control for industry effect and size effect is not unnecessary in the context of this study, since two matching variables in this study (namely, firm size and industry of LBO targets) are related to both the likelihood of firms' going private via LBOs and some other firm-specific variables (See Section 3.3.2 for more details). ${ }^{23}$ This implies that one has conditional information for inferring the outcome (the likelihood of firms' going private via LBOs) from knowing the industry and firm size. Thus, 1-1 matched casecontrol sampling method is the most suitable sampling design for studying explanatory factors of the likelihood of firms' going private via LBOs.

Statistical Methods: To explore explanatory factors of the likelihood of firms' going private via LBOs, the previous literature adopts the following two main statistical methods: 1) Standard maximum likelihood logistic regression estimation; 2) Weighted maximum likelihood estimation (See Appendix $G$ for a detailed explanation of weighted

\footnotetext{
${ }^{23}$ This finding justifies the use of 1-1 matched case-control sampling, since Cram et al (2007) indicate that "matching is useful only if the correlation between the matched variable and the dependent variable is 'substantial'.
} 
maximum likelihood estimation method).

Table 2.3 summarizes sampling method, sample composition, and statistical method adopted by the existing LBO studies on explanatory factors of the likelihood of firms' going private via LBOs. Particularly, Table 2.3 shows whether the statistical method is matched to the sample design in each study. Note that this study is only concerned with testing whether a set of variables bears a significant statistical relationship to the odds of firms' going private via LBOs, rather than using the model to predict which firms might go private via LBOs. Thus, the matching between sampling design and statistical method is discussed only from this perspective. 
Table 2.3 Research Methodologies of the Previous Studies on the Likelihood of Firms' Going Private via LBOs

\begin{tabular}{|c|c|c|c|c|c|c|c|c|}
\hline \multirow[t]{3}{*}{ Study } & \multicolumn{4}{|c|}{ Sampling Design } & \multicolumn{2}{|c|}{ Sample Composition } & \multirow{3}{*}{$\begin{array}{l}\text { Statistical } \\
\text { Method }\end{array}$} & \multirow{3}{*}{$\begin{array}{l}\text { Match/ } \\
\text { Mismatch }\end{array}$} \\
\hline & \multirow{2}{*}{$\begin{array}{l}\text { Case- } \\
\text { control } \\
\text { Samplin } \\
\mathrm{g}\end{array}$} & \multicolumn{2}{|c|}{$\begin{array}{l}\text { Matched Case-control } \\
\text { Sampling }\end{array}$} & \multirow[t]{2}{*}{$\begin{array}{l}\text { Random } \\
\text { Sampling }\end{array}$} & \multirow[t]{2}{*}{$\begin{array}{l}\text { Control } \\
\text { Group }\end{array}$} & \multirow[t]{2}{*}{$\begin{array}{l}\text { Case } \\
\text { Group }\end{array}$} & & \\
\hline & & $\begin{array}{l}1-1 \\
\text { Matched } \\
\text { Case- } \\
\text { control } \\
\end{array}$ & $\begin{array}{l}\text { Semi- } \\
\text { matched } \\
\text { Case- } \\
\text { control }\end{array}$ & & & & & \\
\hline \multirow[t]{2}{*}{$\begin{array}{l}\text { Opler and } \\
\text { Titman } \\
(1993)\end{array}$} & \multirow[t]{2}{*}{$\mathbf{N}$} & \multirow[t]{2}{*}{$\mathrm{N}$} & \multirow[t]{2}{*}{$\mathrm{N}$} & \multirow{2}{*}{$\begin{array}{l}\text { Y: all non- } \\
\text { LBO firms are } \\
\text { selected as } \\
\text { control firms } \\
\text { from } \\
\text { the same } \\
\text { database as } \\
\text { LBOs }\end{array}$} & $\begin{array}{l}1769 \\
\text { (over the } \\
\text { period } \\
1980- \\
1984 \text { ) }\end{array}$ & $\begin{array}{l}69 \text { (over } \\
\text { the period } \\
1980- \\
1984 \text { ) }\end{array}$ & \multirow[t]{2}{*}{$\begin{array}{l}\text { Standard } \\
\text { multinomi } \\
\text { al logistic } \\
\text { Analysis }\end{array}$} & \multirow[t]{2}{*}{ Match } \\
\hline & & & & & $\begin{array}{l}\text { 1551(over } \\
\text { the period } \\
1985- \\
1990 \text { ) }\end{array}$ & $\begin{array}{l}\text { 101(over } \\
\text { the period } \\
1985- \\
1990)\end{array}$ & & \\
\hline $\begin{array}{l}\text { Lehn and } \\
\text { Poulsen } \\
\text { (1989) }\end{array}$ & $\mathbf{N}$ & $\begin{array}{l}\text { Y: } \\
\text { Matching } \\
\text { is based } \\
\text { on firm } \\
\text { size and } \\
\text { industry } \\
\text { SIC code }\end{array}$ & & $\mathbf{N}$ & 263 & 263 & $\begin{array}{l}\text { Standard } \\
\text { logistic } \\
\text { regression }\end{array}$ & Mismatch \\
\hline $\begin{array}{l}\text { Maupin et } \\
\text { al (1984) }\end{array}$ & $\mathbf{N}$ & $\begin{array}{l}\text { Y: Same } \\
\text { as above }\end{array}$ & & $\mathbf{N}$ & 63 & 63 & $\begin{array}{l}\text { Discrimin } \\
\text { ant } \\
\text { analysis }\end{array}$ & Mismatch \\
\hline $\begin{array}{l}\text { Kieschnic } \\
\text { k (1998) }\end{array}$ & $\bar{N}$ & $\begin{array}{l}\text { Y: Same } \\
\text { as above }\end{array}$ & & $\overline{\mathbf{N}}$ & 263 & 263 & $\begin{array}{l}\text { Weighted } \\
\text { maximum } \\
\text { likelihood } \\
\text { estimation }\end{array}$ & Mismatch \\
\hline $\begin{array}{l}\text { Halpern et } \\
\text { al. (1999) }\end{array}$ & $\mathrm{N}$ & $\mathbf{N}$ & $\begin{array}{l}\text { Y: Semi- } \\
\text { matching } \\
\text { based on } \\
\text { year }\end{array}$ & $\mathbf{N}$ & 126 & 126 & $\begin{array}{l}\text { Weighted } \\
\text { maximum } \\
\text { likelihood } \\
\text { estimation }\end{array}$ & Mismatch \\
\hline
\end{tabular}

Note: It terms of case sample, it is important to note that all the previous studies use LBOs as case groups, rather than using LMBOs and LIBOs as different sub-samples as this study does. 
Table 2.3 shows that all the previous studies except Opler and Titman (1993) ${ }^{24}$ adopt the statistical methods that do not match their sampling designs. There are several reasons why the mismatch occurs in most of the previous research on LBO: 1) The differences among random sample, non-matched case-control sample, semi-matched case-control sample, and fully-matched case-control sample are not fully understood in most of the previous research. For example, Lehn and Poulsen (1989) fail to recognize their sample as case-control sample. Kieschnick (1998) and Halpern et al (1999) fail to distinguish matched case-control sample and non-matched case-control sample. 2) Some previous studies fail to fully understand the purpose of using weighted estimation method, resulting in the abuse use of it (See below for further explanation). 3) All the previous studies except Opler and Titman (1993) fail to use appropriate statistical method to deal with semi- or fully-matched case-control sample. Even though some studies like Kieschnick (1998) and Halpern et al (1999) recognize the mismatch problem, some of their discussions regarding this issue are misleading and neither of their statistical methods fully matches their samples. Cram et al (2007) term this omission of the effect of matching variables on the dependent variable as "use of unconditional analysis, when analysis conditional upon effects of matching variables is needed".

Since a mismatch between sampling design and statistical method can be mostly seen in the previous literature, it is necessary to clarify which statistical method is valid for which sampling method from a statistical perspective.

\footnotetext{
${ }^{24}$ It is well accepted that for random sampling design used by Opler and Titman (1993), standard maximum likelihood estimation (including standard logistic regression) is an appropriate statistical method.
} 
First, for non-matched case-control sampling design, standard maximum likelihood estimation is not valid. It is because numbers of observations in case group (LBO group in this study) or in control group (non-LBO group in this study) are not proportional to the size of their categories in the general population under case-control sampling design. These different sampling rates result in a technical error in the analysis of choice-based sample when standard maximum likelihood estimation is applied (Manski \& McFadden, 1981; Cram et al, 2007; Palepu, 1986; Hosmer \& Lemeshow, 2000; Maddala, 1991). See Appendix $\mathrm{H}$ for a detailed explanation of the limitations of standard estimation method under choice-based sampling design. Manski and McFadden (1981) further argue that the disproportionate sampling for different population strata that is implicit in the choicebased sample selection would usually necessitate weighting data in statistical analyses by the sampling rates in each strata. Thus, weighted maximum likelihood estimation should be used to reweight observations according to differing sampling rates (Manski \& McFadden, 1981). However, it is important to note that there is an exception to the general need for the reweighting has been noted in the literature: In terms of standard maximum likelihood estimator used with a choice-based sample, the bias is only in the intercept parameter and other coefficients are unaltered, provided that standard logistic regression is used (Manski \& McFadden, 1981; Palepu, 1986; Hosmer \& Lemeshow, 2000; Maddala, 1991) (See Appendix I for details). ${ }^{25}$

Second, for semi- and fully-matched case-control sampling design, neither standard maximum likelihood estimation nor weighted maximum likelihood estimation method is valid, since neither of them takes matching information into account. Specifically, they

\footnotetext{
${ }^{25}$ In probit model or linear probability model with choice-based sampling, adjustments still need to be made.
} 
both give biased parameters for standard logistic regression model and weighted logistic regression model (Carson \& Hoyt, 2003; Cram et al, 2007) (See Appendix J for details). To take matching into account, for semi-matched case-control sampling design, Cram et al (2007) suggest that different weightings would have to be applied to each strata caused by matching to obtain technically correct coefficients on the research variables of interest in these datasets, if weighted maximum likelihood estimation is used. For 1-1 matched case-control sampling design, one has to process data by comparing cases (i.e. LBOs) and their unique controls (i.e. 1-1 matched non-LBO industry peers) within the matched sets. Cram et al (2007) further argue that a failure of the statistical method to account for industry, size, and other matching variables may have driven incorrect findings in many research studies, or may have suppressed results waiting to be revealed.

Third, for fully-matched case-control sampling design (also called 1-1 matched casecontrol sampling design), Hosmer and Lemeshow (2000) describe a conditional likelihood logistic regression analysis ${ }^{26}$ Conditional logistic regression works in nearly the same way as standard logistic regression, except it is needed to specify which LBO and its matched control firm belong to which pair (or stratum). For example, comparisons of LBOs and their industry peers are made within the matched sets in conditional logistic regression; In contrast, the above comparisons are made across (among) sets in standard logistic regression. To put it another way, conditional logistic regression is analogous to paired-sample t-tests, as it takes differences in each matched case-control pair as variables (See Appendix $\mathrm{K}$ for a detailed discussion of conditional logistic regression). A

\footnotetext{
${ }^{26}$ To avoid confusion about the terminology, it should be noted that the procedures referred to by Manski and McFadden (1981) as conditional maximum likelihood (CMLE) and weighted maximum likelihood (WMLE) are different from the conditional likelihood model discussed in the book by Hosmer and Lemeshow (2000).
} 
paired-sample t-test (a one sample test) is more powerful than an unmatched (two sample) t-test in detecting a mean difference in a given measure. Therefore, one of the advantages of conditional logistic regression over standard logistic regression is that conditional logistic regression is more powerful in distinguishing the difference in firmspecific variables of LBOs from non-LBOs (Cram et al, 2007).

In conclusion, this section describes the sampling methods and statistical methods employed by the previous studies on explanatory factors of the likelihood of firms' going private via LBOs. One major limitation of these studies in terms of their research methodology lies in their invalid statistical methods for their sampling techniques. 


\section{CHAPTER 3: RESEARCH METHODOLOGY}

This chapter describes the research methodology of this study on three subtopics, 1) Changes in LBO deal characteristics over time; 2) Explanatory factors of LBO premiums; and 3) Explanatory factors of the likelihood of firms' going private via LBOs. Hypothesis development and research methodology of this study for these three research areas are discussed in Section 3.1, Section 3.2, and Section 3.3 accordingly. Section 3.4 provides a sample description of this study.

\subsection{Changes in Characteristics of LIBOs and LMBOs over the Period 1985-2005}

\subsubsection{Hypothesis Development}

Hypotheses are developed to investigate whether LBO deal characteristics have greatly changed over the period $1985-2005 .{ }^{27}$

Hypothesis C1: There are significant differences in overall deal characteristics of LMBOs among the three sub periods: $1985-1989,1990-1999$, and 2000-2005. The study period 1985-2005 is broken down into three sub periods, 1985-1989, 1990-1999, and $2000-2005 .^{28}$

\footnotetext{
${ }^{27}$ This study does not include the sub period 1980-1984, since the information on LBOs over this sub period is dated and incomplete. Moreover, there were a very limited number of LMBOs completed over the sub period 1980-1984.

${ }^{28}$ There are two ways to break the study period 1985-2005: 1) The whole study period was broken into four subperiods: $1985-1989,1990-1994,1995-1999$, and 2000-2005; 2) The whole study period was broken into three subperiods: $1985-1989,1990-1999$, and 2000-2005. This study performs a two-group (representing 1990-1994 and $1995-$ 1999) 1-way MANOVA analysis. However, this study does not see any significant differences in LMBO deal characteristics between these two sub periods. Moreover, there are just a few LMBOs announced over the sub period 1990-1994. Therefore, this study combines 1990-1994 and 1995-1999, and this study only reports the result of threegroup (representing 1985-1989, 1990-1999, and 2000-2005) 1-way MANOVA.
} 
Hypothesis C2: There are significant differences in overall deal characteristics of LIBOs between the two sub-periods: $1995-1999$ and $2000-2005 .^{29}$

Hypothesis C3: There are significant differences in overall deal characteristics between LMBOs and LIBOs over the periods 1995-2005.

In order to test the overheated market hypothesis, this study includes most of the key variables examined by Kaplan and Stein (1993). This study also includes some key variables based on the value source related theories. The variables adopted by this study to examine Subtopic 1 and their proxies are listed in Table 3.1. Note that the proxies and theoretical backgrounds for some of these variables are discussed in greater details in Section 3.2.

\footnotetext{
${ }^{29}$ The data of this study shows that LIBOs did not take place until the middle 1990s.
} 


\section{Table 3.1 Variables used to Explore Changes in Characteristics of LBOs and their Proxies}

\begin{tabular}{|c|c|}
\hline Variable & Proxy \\
\hline Volatility of cash flow & $\begin{array}{l}\text { Five years' standard deviation of the quarterly EBITDA/Sales of LBO prior } \\
\text { to LBO announcement }\end{array}$ \\
\hline \multirow{2}{*}{$\begin{array}{l}\text { Undistributed free cash } \\
\text { flow (1 year prior to } \\
\text { LBO announcement) }\end{array}$} & (EBITDA-Tax-Interest-Dividends)/Net Sales \\
\hline & $\begin{array}{l}\text { (EBITDA-Tax-Interest-Dividends-Capital Expenditures-Net Change in } \\
\text { Working Capital) /Net Sales }\end{array}$ \\
\hline $\begin{array}{l}\text { Tax expenditures (1 year } \\
\text { prior to } \mathrm{LBO} \\
\text { announcement) }\end{array}$ & $\begin{array}{l}\text { (Tax expenditures - Deferred tax from the previous year to the current year) / } \\
\text { Net Sales }\end{array}$ \\
\hline Multiplier & Transaction value/EBITDA twelve months prior to LBO announcement \\
\hline $\begin{array}{l}\text { Ratio of total deal fees } \\
\text { and total transaction } \\
\text { value }\end{array}$ & Total deal fees/Total transaction value \\
\hline Relative P/E & The ratio of the companies' $\mathrm{P} / \mathrm{E}$ and an industry peer group's $\mathrm{P} / \mathrm{E}$ \\
\hline Deal size & Transaction value of LBO deal \\
\hline $\begin{array}{l}\text { Assumed liability } \\
\text { /Transaction value }\end{array}$ & Assumed debt/Transaction value \\
\hline Investment opportunities & $\begin{array}{l}\text { Tobin's Q (Total market value/Total asset value one year prior to LBO } \\
\text { announcement) }\end{array}$ \\
\hline \multirow[t]{3}{*}{ LBO premiums } & $\begin{array}{l}\text { Premium of offer price to target closing stock price } 1 \text { week prior to the } \\
\text { original announcement date, expressed as a percentage ((Offer Price - Stock } \\
\text { Price } 1 \text { Week Prior to Announcement) / Stock Price } 1 \text { Week Prior to } \\
\text { Announcement }) * 100)\end{array}$ \\
\hline & $\begin{array}{l}\text { Premium of offer price to target closing stock price } 1 \text { day prior to the original } \\
\text { announcement date, expressed as a percentage ((Offer Price - Stock Price } 1 \\
\text { Day Prior to Announcement) / Stock Price } 1 \text { Day Prior to Announcement) * } \\
100)\end{array}$ \\
\hline & $\begin{array}{l}\text { Premium of offer price to target closing stock price } 4 \text { weeks prior to the } \\
\text { original announcement date, expressed as a percentage ((Offer Price - Stock } \\
\text { Price } 1 \text { Day Prior to Announcement) / Stock Price } 4 \text { Weeks Prior to } \\
\text { Announcement) } * 100)\end{array}$ \\
\hline Dividend payout ratio & $\begin{array}{l}\text { Three-year averaged dividend payout ratio immediately preceding the year of } \\
\text { LIBO or LMBO announcement }\end{array}$ \\
\hline Managerial ownership & The percentage of voting stock held by officers and directors of the company \\
\hline
\end{tabular}




\subsubsection{Research Methodology}

Hypothesis $\mathrm{C} 1$ is tested by 3 -group (representing the three sub periods, namely, 19851989, 1990-1999, and 2000-2005), 1-way MANOVA (See Appendix L for an introduction to MANOVA). Multiple comparisons are also performed as follow-up analyses to identify specific variables contributing to the multivariate pairwise differences among the groups. For LIBOs, hypothesis C2 is tested using 2-group (representing the two sub periods, namely, 1995-1999 and 2000-2005) one-way MANOVA and follow-up t-tests. Regarding hypothesis C3, comparisons between LIBOs and LMBOs is performed separately over the two sub periods $1995-1999$ and 2000$2005 .{ }^{30}$ In this case, 2-group (representing LIBOs and LMBOs) one-way MANOVA and follow-up t-tests are performed separately for the sub period 1995-1999 and 2000-2005.

\subsection{Explanatory Factors of the Premiums Paid to Shareholders of LIBOs and LMBOs}

\subsubsection{Hypothesis Development}

The main purposes of exploring the factors explaining the LIBO and LMBO premiums in this study is to provide implications for the three working theories (namely, the free cash flow hypothesis, the heterogeneity hypothesis, and the overheated market hypothesis) and the two other hypotheses (namely, the market undervaluation hypothesis and the asymmetric information hypothesis). Variable selection for this subtopic is thus mainly

\footnotetext{
${ }^{30}$ This is because the overall deal characteristics of either LIBOs or LMBOs have changed significantly over the period 1995-2005. Note that if the overall deal characteristics of both LIBOs and LMBOs remained unchanged over the period 1995-2005 (which is tested by Hypothesis C1 and C2), LIBOs would be compared with LMBOs over the period 19952005.
} 
based on these five value source related hypotheses.

Free Cash Flow Hypothesis: Under the free cash flow hypothesis, this study examines the relations between the premiums in LIBOs/LMBOs and the firm-specific variables including (i) pre-buyout level of free cash flow, (ii) investment opportunities (proxied by Tobin's Q), (iii) volatility of cash flow, and (iv) dividend payout ratio.

As a key variable to test the FCF hypothesis, a firm's pre-buyout level of free cash flow is defined as cash flow in excess of what is required to fund all positive net present value projects (Jensen, 1986). Since it is impossible to actually determine all positive net present value projects available to each firm, this study uses two slightly different proxies to measures it: (EBITDA-Tax-Interest-Dividends)/Net Sales and (EBITDA-Tax-InterestDividends-Capital Expenditure-Net Change in Working Capital)/Net Sales. Both of these proxies include all cash inflows and exclude the cash flows distributed to the other shareholders (i.e. cash dividends 1 year prior to LBO announcement). The cash outflows deducted represent payments that management is obliged to make, which effectively reduce the amount of cash available for discretionary spending. Following Halpern et al (1999), this study uses net sales, rather than market value one year prior to LBO announcement, to scale the free cash flow variable. ${ }^{31}$

\footnotetext{
31 Tax expenditures and free cash flow are scaled by firms' net sales to control size effect in this study. The premiums are expected to be found higher for smaller LBO firms, since there is more asymmetric information in small LBO targets. The small companies are usually not adequately covered by analysts and the financial press, while the bigger firms are better known and are unlikely to have systematically hidden information about earnings and prospects.
} 
Under the FCF hypothesis, Tobin's Q (the ratio of the market value of the firm's assets to their replacement cost of capital) is employed to proxy for investment opportunities. The Q-theory of investment predicts that a firm's investment rate will rise with its Tobin's Q (Brainard \& Tobin, 1968). In equilibrium, every firm should have a value of Tobin's Q as 1. If a firm's Tobin's $Q$ is above 1, it should stimulate investment. If Tobin's $Q$ is below 1 , it should discourage investment. However, some researchers argue that Tobin's $Q$ is not an accurate proxy for investment opportunities and particularly it may be influenced by a number of factors (Fazzari, Hubbard, \& Petersen, 1998; Gomme, 2005; Kim, Henderson, \& Glenn, 1993). As discussed earlier, Tobin's Q may have high multicollinearity with industry, firm size, free cash flow, dividend payout ratio, stock price, and market conditions. For example, owing to the stock price bubble, a firm's Tobin's Q may rise and go beyond 1, so firms may be buying capital goods when they "shouldn't be" (Gomme, 2005). Two methods are used to control multicollinearity in this study: correlations among the independent variables and Variance Inflation Factor (VIF) (See Section 3.2.2 for more details).

Two more variables, volatility of cash flow (which is rarely examined by the previous research) and dividend payout ratio, are also added to LBO literature under the FCF hypothesis. A negative relation is expected between volatility of cash flow and LBO premiums, as high volatility of cash flow implies high risk for financial distress of LBOs. A positive relation is expected between dividend payout ratio and LBO premiums, as typical candidates for LBOs are mature, slow-growth companies that have higher 
dividend payout ratios. ${ }^{32}$ The expected positive sign for dividend payout ratio is also based on Maupin et al (1984)'s finding that LMBO firms are characterized by both higher prior undistributed cash flows and higher cash dividends.

Heterogeneity Hypothesis: LIBOs are assumed to have different value sources than LMBOs under the heterogeneity hypothesis of this study. This study thus expects to find different sets of explanatory factors of the LBO premiums for LIBOs and LMBOs. This study includes the interaction between LBO type dummy variable and each of the firmspecific variables in regression analysis. Particularly, this study expects to identify the interaction of LBO type dummy variable with managerial ownership as a significant explanatory factor of LBO premiums. This hypothesis is based on Halpern et al (1999)'s comment that it would be harder for institutions to take private the firms with higher levels of managerial ownership, while managements that possess higher levels of managerial ownership have less difficulty in taking their firms private. This hypothesis is different from the FCF hypothesis: The FCF hypothesis assumes a negative relation between LBO premiums and managerial ownership as there are more agency costs in firms with lower managerial ownership. Other than the managerial ownership, this study does not have much prior information or theoretical foundation to hypothesize whether any other firm-specific characteristics are different between LIBOs and LMBOs. Thus, only the interaction between managerial ownership and LBO type dummy variable is listed in Table 3.2, though the other interactions are also examined in this study.

\footnotetext{
${ }^{32}$ Unlike Maupin et al (1984), dividend payout ratio, instead of dividend yield, is used, since dividend yield may include the information of stock performance of LBO during the pre-LBO period. In addition, the earning per share tend to be low or even negative immediately before LBO announcement, so this study uses three-year averaged dividend payout ratio to avoid the possible negative numbers.
} 
Market Overheated Hypothesis: It is possible that the value created for shareholders of LBO targets may come from different sources in the overheated market conditions. Thus, this study expects to find different sets of explanatory factors for LBO premiums over time. For example, this study expects to find changing market undervaluation effects on LBO premiums over time, since irrational acquirers may pay less attention to undervaluation of LBO target firms in the overheated market conditions.

Market Undervaluation Hypothesis: The market undervaluation hypothesis assumes that the more an LBO target is undervalued prior to the buyout, the more premiums would be paid to take it private. This study uses relative P/E ratio (the ratio of an LBO company's $\mathrm{P} / \mathrm{E}$ and an industry peer group's $\mathrm{P} / \mathrm{E}$ ) to proxy for stock undervaluation of LBO. As discussed earlier, the findings on Tobin's $Q$ can be subjected to both the free cash flow explanation and the market undervaluation explanation. This study thus includes both relative $\mathrm{P} / \mathrm{E}$ and Tobin's $\mathrm{Q}$ (proxying for investment opportunities) to separate the effect of undervaluation from that of potential agency cost reduction on LBO premiums.

Asymmetric Information Hypothesis: Under the asymmetric information hypothesis, this study expects to find the market undervaluation effect more significant for LMBOs, as it is likely that more asymmetric information between managements and public investors for LMBOs may cause more undervaluation of LMBO targets.

Table 3.2 presents the above hypotheses and the corresponding variables and proxies examined by this study. 
Table 3.2 Research Hypotheses on Factors Explaining the Premiums Paid to Shareholders of LIBOs and LMBOs

\begin{tabular}{|c|c|c|c|c|}
\hline Theory & Issue & Hypothesis & Proxy & $\begin{array}{l}\text { Sign } \\
\text { Expected }\end{array}$ \\
\hline $\begin{array}{l}\text { Market } \\
\text { Undervaluation } \\
\text { Hypothesis }\end{array}$ & Relative P/E & $\begin{array}{l}\text { Hypothesis P1: The lower } \\
\text { the companies' P/E ratio } \\
\text { compared to the industry } \\
\text { peer firms, the higher } \\
\text { premiums paid for LMBOs } \\
\text { and LIBOs. }\end{array}$ & $\begin{array}{l}\text { Ratio of an LBO } \\
\text { company's } \mathrm{P} / \mathrm{E} \text { and an } \\
\text { industry peer group's } \mathrm{P} / \mathrm{E}\end{array}$ & - \\
\hline $\begin{array}{l}\text { Free Cash } \\
\text { Flow } \\
\text { Hypothesis }\end{array}$ & $\begin{array}{l}\text { Volatility of } \\
\text { cash flow }\end{array}$ & $\begin{array}{l}\text { Hypothesis P2: Higher } \\
\text { premiums are paid for } \\
\text { LMBOs and LIBOs with } \\
\text { lower volatility of free cash } \\
\text { flow. }\end{array}$ & $\begin{array}{l}\text { Five years' standard } \\
\text { deviation of the quarterly } \\
\text { EBITDA/Sales of LBO } \\
\text { prior to LBO } \\
\text { announcement }\end{array}$ & - \\
\hline $\begin{array}{l}\text { Free Cash } \\
\text { Flow } \\
\text { Hypothesis }\end{array}$ & $\begin{array}{l}\text { Dividend } \\
\text { payout ratio }\end{array}$ & $\begin{array}{l}\text { Hypothesis P3: Higher } \\
\text { premiums are paid for } \\
\text { LMBOs and LIBOs with } \\
\text { higher dividend payout } \\
\text { ratios. }\end{array}$ & $\begin{array}{l}\text { Three-year averaged } \\
\text { dividend payout ratio } \\
\text { immediately preceding } \\
\text { the announcement of } \\
\text { LIBO or LMBO } \\
\text { announcement }\end{array}$ & + \\
\hline $\begin{array}{l}\text { Free Cash } \\
\text { Flow } \\
\text { Hypothesis }\end{array}$ & $\begin{array}{l}\text { Investment } \\
\text { opportunities }\end{array}$ & $\begin{array}{l}\text { Hypothesis P4: Higher } \\
\text { premiums are paid for } \\
\text { LMBOs and LIBOs with } \\
\text { less quality of investment } \\
\text { opportunities. }\end{array}$ & Tobin's Q & - \\
\hline $\begin{array}{l}\text { N/A (control } \\
\text { variable) }\end{array}$ & $\begin{array}{l}\text { Challenged } \\
\text { deals }\end{array}$ & $\begin{array}{l}\text { Hypothesis P5: Higher } \\
\text { premiums are paid for } \\
\text { LMBOs and LIBOs when } \\
\text { there are challenged deals. }\end{array}$ & $\begin{array}{l}\text { "1" where a third party } \\
\text { launched an offer for the } \\
\text { target, while this original } \\
\text { bid was pending; "0" } \\
\text { otherwise }\end{array}$ & + \\
\hline $\begin{array}{l}\text { N/A (control } \\
\text { variable) }\end{array}$ & $\begin{array}{l}\text { Tax } \\
\text { expenditures (1 } \\
\text { year prior to } \\
\text { LBO } \\
\text { announcement) } \\
\end{array}$ & $\begin{array}{l}\text { Hypothesis P6: Higher } \\
\text { premiums are paid for } \\
\text { LMBOs and LIBOs with } \\
\text { higher tax expenditures. }\end{array}$ & $\begin{array}{l}\text { (Tax expenditures - } \\
\text { Deferred tax from the } \\
\text { previous year to the } \\
\text { current year) / Net sales }\end{array}$ & + \\
\hline \multirow[t]{2}{*}{$\begin{array}{l}\text { Free Cash } \\
\text { Flow } \\
\text { Hypothesis }\end{array}$} & \multirow{2}{*}{$\begin{array}{l}\text { Undistributed } \\
\text { cash flow (1 } \\
\text { year prior to } \\
\text { LBO } \\
\text { announcement) }\end{array}$} & \multirow{2}{*}{$\begin{array}{l}\text { Hypothesis P7: Higher } \\
\text { premiums are paid for } \\
\text { LMBOs and LIBOs with } \\
\text { higher pre-buyout levels of } \\
\text { free cash flow. }\end{array}$} & $\begin{array}{l}\text { 1) (EBITDA-Tax- } \\
\text { Interests-Dividends)/ Net } \\
\text { sales }\end{array}$ & \multirow[t]{2}{*}{+} \\
\hline & & & $\begin{array}{l}\text { 2) (EBITDA-Tax- } \\
\text { Interests-Dividends- } \\
\text { Capital Expenditures-Net } \\
\text { Change in Working } \\
\text { Capital)/ Net sales }\end{array}$ & \\
\hline $\begin{array}{l}\text { Heterogeneity } \\
\text { Hypothesis }\end{array}$ & $\begin{array}{l}\text { Managerial } \\
\text { ownership* } \\
\text { LBO type }\end{array}$ & $\begin{array}{l}\text { Hypothesis P8: Higher } \\
\text { premiums are paid for } \\
\text { LMBOs with lower pre- } \\
\text { buyout levels of managerial } \\
\text { ownership or LIBOs with } \\
\text { higher pre-buyout levels of } \\
\text { managerial ownership. }\end{array}$ & $\begin{array}{l}\text { The percentage of voting } \\
\text { stock held by officers and } \\
\text { directors of the company; } \\
\text { "1" represents LMBOs; } \\
\text { "-1" represents LIBOs }\end{array}$ & - \\
\hline
\end{tabular}

Note: Following the previous studies, challenged deals and tax expenditures are also included as control variables in this study. 
The above eight univariate hypotheses of this study can also be expressed as:

Premium $_{\mathrm{i}}=\mathrm{a}_{0}+\mathrm{a}_{1}$ RelativeP/E $_{\mathrm{i}}+\mathrm{a}_{2}$ ManagerialOwnership $_{\mathrm{i}}+\mathrm{a}_{3}$ VolatilityofCashflow $_{\mathrm{i}}+$ $a_{4}$ DividendPayoutRatio $_{i}+a_{5}$ Tobin's $_{i}+a_{6}$ ChallengedDeal $_{i}+a_{7}$ TaxExpenditures $_{i}+$ $\mathrm{a}_{8}$ UndistributedFreeCashFlow $_{\mathrm{i}}+\mathrm{a}_{9}$ LBOType* $^{*}$ (any of the other independent variables) $)_{\mathrm{i}}+$ $e_{i}$

\subsubsection{Research Methodology}

OLS regressions with LBO premium as dependent variable are performed to explore the value sources of LBOs over each sub period. Regression models in this study are developed based on the following factors: First, the nature of regression models is primarily determined by the research hypotheses listed in Table 3.2. Second, based on correlations among the independent variables and Variance Inflation Factor (VIF) ${ }^{33}$, different sets of independent variables are included in different regression models. Third, the number of variables included in each regression model is also limited by the sample size of LBOs over each sub period.

It is important to note that there are two components in the models of this study: the main effects of the explanatory variables and the interaction effects of the explanatory variables with LBO type dummy variable. In OLS regression, the main effects alone imply that the firm-specific variables have a constant effect on LBO premiums. The presence of significant interaction terms along with the main effects implies that the

\footnotetext{
33 Taking into account multicollinearity (examined by VIF) into consideration, this study uses cut-off of VIF $>=6$ when multicollinearity is a problem.
} 
effects of independent firm-specific variables (i.e. managerial ownership or undistributed free cash flow) on LBO premiums differ across LBO type. In other words, it usually implies that the regression coefficients of these variables would be significantly different if separate regressions were run for LIBO and LMBO samples. This study runs different OLS regression models with and without each interaction term to decide which interaction variable to include by checking the improvement of model fits.

\subsection{Explanatory Factors of the Likelihood of Firms' Going Private via LIBOs or LMBOs}

\subsubsection{Hypothesis Development}

In terms of factors explaining the likelihood of firms' going private via LBOs, the research hypotheses evaluated in this study are presented in Table 3.3. As in Subtopic 2, these research hypotheses are also developed based on the three key working theories and two additional theories (See Section 3.2.1 for the theoretical background for each variable). 


\section{Table 3.3 Research Hypotheses on Factors Explaining the Likelihood of Firms' Undertaking LIBOs and LMBOs}

\begin{tabular}{|c|c|c|c|c|}
\hline Theory & Issue & Hypothesis & Proxy & $\begin{array}{l}\text { Sign } \\
\text { Expected }\end{array}$ \\
\hline $\begin{array}{l}\text { Market } \\
\text { Undervaluation } \\
\text { Hypothesis }\end{array}$ & $\mathrm{P} / \mathrm{E}$ & $\begin{array}{l}\text { Hypothesis L1: Firms } \\
\text { with lower P/E ratios are } \\
\text { more likely to go private } \\
\text { via LMBOs or LIBOs. }\end{array}$ & $\begin{array}{l}\mathrm{LBO} \text { company's } \mathrm{P} / \mathrm{E} \\
\text { ratio }\end{array}$ & - \\
\hline $\begin{array}{l}\text { Free Cash } \\
\text { Flow } \\
\text { Hypothesis }\end{array}$ & $\begin{array}{l}\text { Volatility of } \\
\text { cash flow }\end{array}$ & $\begin{array}{l}\text { Hypothesis L2: Firms } \\
\text { with lower volatility of } \\
\text { free cash flow are more } \\
\text { likely to go private via } \\
\text { LMBOs or LIBOs. }\end{array}$ & $\begin{array}{l}\text { Five years' standard } \\
\text { deviation of the quarterly } \\
\text { EBITDA/Sales of LBOs } \\
\text { prior to LBO } \\
\text { announcement }\end{array}$ & - \\
\hline $\begin{array}{l}\text { Free Cash } \\
\text { Flow } \\
\text { Hypothesis }\end{array}$ & $\begin{array}{l}\text { Dividend } \\
\text { payout ratio }\end{array}$ & $\begin{array}{l}\text { Hypothesis L3: Firms } \\
\text { with higher dividend } \\
\text { payout ratios are more } \\
\text { likely to go private via } \\
\text { LMBOs or LIBOs. }\end{array}$ & $\begin{array}{l}\text { Three-year averaged } \\
\text { dividend payout ratio } \\
\text { immediately preceding } \\
\text { the announcement of } \\
\text { LIBO or LMBO } \\
\text { announcement }\end{array}$ & + \\
\hline $\begin{array}{l}\text { Free Cash } \\
\text { Flow } \\
\text { Hypothesis }\end{array}$ & $\begin{array}{l}\text { Investment } \\
\text { opportunities }\end{array}$ & $\begin{array}{l}\text { Hypothesis L4: Firms } \\
\text { with lower investment } \\
\text { opportunities are more } \\
\text { likely to go private via } \\
\text { LMBOs or LIBOs. } \\
\end{array}$ & Tobin's Q & - \\
\hline $\begin{array}{l}\text { N/A (control } \\
\text { variable) }\end{array}$ & $\begin{array}{l}\text { Unscaled tax } \\
\text { expenditures } \\
\text { (1 year prior to } \\
\text { LBO } \\
\text { announcement) } \\
\end{array}$ & $\begin{array}{l}\text { Hypothesis L5: Firms } \\
\text { with higher tax } \\
\text { expenditures are more } \\
\text { likely to go private via } \\
\text { LMBOs or LIBOs. } \\
\end{array}$ & $\begin{array}{l}\text { (Tax expenditures - } \\
\text { Deferred tax from the } \\
\text { previous year to the } \\
\text { current year) }\end{array}$ & + \\
\hline \multirow[t]{2}{*}{$\begin{array}{l}\text { Free Cash } \\
\text { Flow } \\
\text { Hypothesis }\end{array}$} & \multirow{2}{*}{$\begin{array}{l}\text { Unscaled } \\
\text { undistributed } \\
\text { cash flow (1 } \\
\text { year prior to } \\
\text { LBO } \\
\text { announcement) }\end{array}$} & \multirow{2}{*}{$\begin{array}{l}\text { Hypothesis L6: Firms } \\
\text { with higher pre-buyout } \\
\text { levels of free cash flow } \\
\text { are more likely to go } \\
\text { private via LMBOs or } \\
\text { LIBOs. }\end{array}$} & $\begin{array}{l}\text { 1) (EBITDA-Tax- } \\
\text { Interests-Dividends) }\end{array}$ & \multirow[t]{2}{*}{+} \\
\hline & & & $\begin{array}{l}\text { 2) (EBITDA-Tax- } \\
\text { Interests-Dividends- } \\
\text { Capital Expenditures-Net } \\
\text { Change in Working } \\
\text { Capital) }\end{array}$ & \\
\hline $\begin{array}{l}\text { Heterogeneity } \\
\text { Hypothesis }\end{array}$ & $\begin{array}{l}\text { Managerial } \\
\text { ownership* } \\
\text { LBO type }\end{array}$ & $\begin{array}{l}\text { Hypothesis L7: Firms } \\
\text { with lower pre-buyout } \\
\text { levels of managerial } \\
\text { ownership are more likely } \\
\text { to go private via LIBOs } \\
\text { and firms with higher pre- } \\
\text { buyout levels of } \\
\text { managerial ownership are } \\
\text { more likely to go private } \\
\text { via LMBOs. }\end{array}$ & $\begin{array}{l}\text { The percentage of voting } \\
\text { stock held by officers } \\
\text { and directors of the } \\
\text { company }\end{array}$ & + \\
\hline
\end{tabular}

Note: Due to the size effects are controlled in the matching, tax expenditures and undistributed free cash flow variables are not scaled by net sales of $L B O$ firms within this research subtopic. 


\subsubsection{Research Methodology}

As discussed in Section 2.2.4, this study uses a 1-1 matched case-control sampling design to increase the statistical precision of the estimation by controlling industry effects and size effects (See Section 2.2.4 for the reasons why neither random sampling nor semimatched case-control sampling can be used in this study). Specifically, this study matches LBOs with control firms based on the similarity in firm size proxied by market value of pre-LBO firms one year prior to LBO announcement date and industry SIC code. ${ }^{34}$ Sampling procedures for control firms are described in Section 3.4.1.

In terms of statistical method, this study first performs paired-samples t-tests to compare the firm-specific variables between LBOs and their industry peers. An independentsample t-test cannot be applied to the data of this study. Paired t-test focuses on the differences in the two values for every matched case-control pair, while independentsample t-test focuses on the average difference between cases and controls without takes into the correlations between cases and matched controls. Thus, compared to independent-samples t-test, the paired-samples t-test is more likely to pick up a significant difference.

This study then performs conditional logistic regression to explore the factors that may explain the likelihood of firms' going private via LBOs. To empirically justify the use of conditional logistic regression for 1-1 matched case-control sampling design, this study

\footnotetext{
${ }^{34}$ As noted earlier, the proposed matched variables (industry and firm size) are found strongly related to both the likelihood of firms' going private via LBOs and some independent firm-specific variables.
} 
further compares the results between conditional logistic regression and standard logistic regression.

In summary, Section 3.1, Section 3.2, and Section 3.3 describe the research hypotheses and methodologies for the three sub topics of this study. A summary of all the variables and their proxies used by this study is provided in Table 3.4 . 
Table 3.4 Summary of the Variables Used in the Analyses of This Study (Across All Chapters) and Their Definitions

\begin{tabular}{|c|c|}
\hline Variable & Definition \\
\hline Premiums 1 Week prior to LBO Announcement & $\begin{array}{l}\text { Premium of offer price to target closing stock price } \\
1 \text { week prior to the original announcement date, } \\
\text { expressed as a percentage ((Offer Price - Stock } \\
\text { Price } 1 \text { Week Prior to Announcement }) / \text { Stock Price } \\
1 \text { Week Prior to Announcement }) * 100)\end{array}$ \\
\hline Premiums 1 Day prior to LBO Announcement & $\begin{array}{l}\text { Premium of offer price to target closing stock price } \\
1 \text { day prior to the original announcement date, } \\
\text { expressed as a percentage ((Offer Price - Stock } \\
\text { Price } 1 \text { Day Prior to Announcement }) \text { / Stock Price } 1 \\
\text { Day Prior to Announcement }) * 100)\end{array}$ \\
\hline Premiums 4 Weeks prior to LBO Announcement & $\begin{array}{l}\text { Premium of offer price to target closing stock price } \\
4 \text { weeks prior to the original announcement date, } \\
\text { expressed as a percentage }((\text { Offer Price - Stock } \\
\text { Price } 4 \text { weeks Prior to Announcement }) / \text { Stock Price } \\
4 \text { Weeks Prior to Announcement }) * 100)\end{array}$ \\
\hline \multirow[t]{2}{*}{ Scaled/Unscaled Undistributed Free Cash Flow } & $\begin{array}{l}\text { Undistributed free cash flow (EBITDA-Tax- } \\
\text { Interest-Dividends) } 1 \text { year prior to LBO } \\
\text { announcement (scaled by net sales of LBO firm) }\end{array}$ \\
\hline & $\begin{array}{l}\text { Undistributed free cash flow (EBITDA-Tax- } \\
\text { Interest-Dividends-Capital Expenditures-Net } \\
\text { Change in Working Capital) } 1 \text { year prior to LBO } \\
\text { announcement (scaled by net sales of LBO firm) }\end{array}$ \\
\hline Volatility of Cash Flow & $\begin{array}{l}\text { Five years' standard deviation of the quarterly } \\
\text { EBITDA/Sales of LBO prior to LBO announcement }\end{array}$ \\
\hline Scaled/Unscaled Tax Expenditures & $\begin{array}{l}\text { Tax expenditures } 1 \text { year prior to LBO } \\
\text { announcement subtracted by deferred tax from the } \\
\text { previous year to the current year (Tax expenditures - } \\
\text { Deferred tax from the previous year to the current } \\
\text { year) (scaled by net sales of LBO firm) }\end{array}$ \\
\hline Multiplier (Transaction Value/EBITDA) & $\begin{array}{l}\text { Ratio of transaction value of LBO deal to LBO } \\
\text { firm's EBITDA twelve months prior to LBO } \\
\text { announcement }\end{array}$ \\
\hline Total Deal Fee/ Transaction Value & Ratio of total deal fees to total transaction value \\
\hline Relative P/E & $\begin{array}{l}\text { The ratio of an LBO company's } P / E \text { and an industry } \\
\text { peer group's P/E }\end{array}$ \\
\hline Deal Size & Transaction value of LBO deal \\
\hline Assumed Liability / Transaction Value & $\begin{array}{l}\text { Ratio of assumed debt to transaction value of LBO } \\
\text { deal }\end{array}$ \\
\hline Investment Opportunities (Tobin's Q) & $\begin{array}{l}\text { Ratio of total market value to total asset value of } \\
\text { LBO firm } 1 \text { year prior to LBO announcement }\end{array}$ \\
\hline 3 Year Average Dividend Payout Ratio & $\begin{array}{l}\text { Three-year averaged dividend payout ratio } \\
\text { immediately preceding the year of LIBO or LMBO } \\
\text { announcement }\end{array}$ \\
\hline Challenged Deal Dummy & $\begin{array}{l}\text { "1" where a third party launched an offer for the } \\
\text { target, while this original bid was pending; " } 0 \text { " } \\
\text { otherwise }\end{array}$ \\
\hline Managerial Ownership & $\begin{array}{l}\text { The percentage of voting stock held by officers and } \\
\text { directors of the company }\end{array}$ \\
\hline
\end{tabular}

Note: Due to the size effects are controlled in the matching, tax expenditures and undistributed free cash flow variables are not scaled by net sales of LBO firms within Subtopic 3. 


\subsection{Sample}

\subsubsection{Dataset for this Study}

This study considers all the completed U.S. LMBOs and LIBOs that occurred between 1985 and 2005. This study follows the following procedures to obtain the dataset:

1) Collect the completed U.S. "LBOs" that took place over the period 1985-2005 according to the SDC Thomas Financial Database. ${ }^{35}$

2) Examine whether these firms satisfy the criterion that $100 \%$ of the public firms went private. This leads to the final list of LBO firms by excluding the division sales and the private firms that were bought out. ${ }^{36}$

3) Exclude the deals whose information on the amount of debt financing is not disclosed or less than $30 \%$ of transaction value.

4) Identify LMBOs and LIBOs based on the initiator of each LBO using the searching criteria in the SDC Thomas Financial Database and their buyout statements. $^{37}$

\footnotetext{
${ }^{35}$ Note that the definition of LBOs in the SDC Thomas Financial Database is slightly different than the definition of LBOs used in this study: Some of the LBOs in the SDC Thomas Financial Database do not satisfy the requirement of LBO definition for this study, which is that $100 \%$ of the public company has to be taken private. In addition, the amount of debt incurred in LBO transaction is not clearly specified in the SDC Thomas Financial Database, and this study finds some of the deals use less amount of debt financing than required.

${ }^{36}$ There are two main reasons why division sales of public firms are excluded: 1) It is usually difficult to obtain complete financial information on these deals and it is almost impossible to find 1-1 matched control firms for these divisions sales; 2) Generally, the purposes of the division sales are different than the of firms that undertake LBOs. ${ }^{37}$ This study adopts the same definitions of LMBO and LIBO as those of "Management Buyout" and "Institutional Buyout" defined in the SDC Thomas Financial Database. By selecting "managerial buyout" and "institutional buyout" in the search function of the SDC Thomas Financial Database, this study can have a list of LMBOs and LIBOs correspondingly. In addition to relying on the searching criteria in SDC, this study also went through the buyout statements of these LIBOs and LMBOs to double check the SDC Thomas Financial Database's classifications of LBO types.
} 
A description of the sampling procedures for 1-1 matched control firms in this study is provided as follows. ${ }^{38}$

1) From the Compustat database, the control firms are matched with target firms by the four-digit SIC code, all the firms that are publicly traded and with the same SIC code.

2) For a particular LBO firm, a matching control firm is selected from among the non-LBO firms identified in the first step by taking the one with the market value of equity that most closely matches particular LBO firm's market value one year prior to the LBO announcement.

3) The matching firm is then removed from the set of candidate matches identified in Step 1.

4) Steps 1 and 2 are repeated for all selected LBO firms to locate their paired publicly-traded firms, and the corresponding financial information of these control firms is collected from Compustat Database.

The sample size for this study is presented in Table $3.5 .^{39}$

\footnotetext{
${ }^{38}$ Note that this 1-1 matched case-control sampling design is used only for the subtopic of the explanatory factors of the likelihood of firms' going private via LBOs.

${ }^{39}$ As noted earlier, this study uses $30 \%$ ratio of assumed liability to transaction value, instead of $50 \%$ (used by Halpern et al (1999)), to define LBOs.
} 
Table 3.5 Sample Size of This Study

In column 1\&5, "\# of potential LMBOs" and "\# of potential LIBOs" were calculated based on the datasets obtained from Step 2 of the above sampling procedure. These deals meet all the requirements of being considered as LMBOs or LIBOs except the amount of debt incurred in the transactions. This study thus calls these deals "potential LMBOs (or LIBOs)". In column 2\&6, "Potential LMBOs (or LIBOs) with debt information" represent potential LMBOs (or LIBOs) with debt information disclosed in their buyout statements. Column $3 \& 7$ list \# of potential LMBOs (or LIBOs) with more than $30 \%$ of assumed liability to transaction value. Column $4 \& 8$ list \# of potential LMBOs (or LIBOs) with more than $50 \%$ of assumed liability to transaction value. As discussed earlier, this study selects LMBOs (or LIBOs) with more than $30 \%$ of assumed liability to transaction value for the final dataset.

\begin{tabular}{|c|c|c|c|c|c|c|c|c|c|c|c|c|c|c|}
\hline \multirow[t]{2}{*}{ Year } & \multirow[t]{2}{*}{$\begin{array}{l}\text { 1) \# of } \\
\text { potenti } \\
\text { al } \\
\text { LMB } \\
\text { Os }\end{array}$} & \multicolumn{2}{|c|}{$\begin{array}{l}\text { 2) Potential } \\
\text { LMBOs } \\
\text { with debt } \\
\text { information }\end{array}$} & \multicolumn{2}{|c|}{$\begin{array}{l}\text { 3) LMBOs } \\
\text { with more } \\
\text { than } 30 \% \\
\text { assumed } \\
\text { liability to } \\
\text { transaction } \\
\text { value }\end{array}$} & \multicolumn{2}{|c|}{$\begin{array}{l}\text { 4) LMBOs } \\
\text { with more } \\
\text { than } 50 \% \\
\text { assumed } \\
\text { liability to } \\
\text { transaction } \\
\text { value }\end{array}$} & \multirow[t]{2}{*}{$\begin{array}{l}5) \# \\
\text { of } \\
\text { Pote } \\
\text { ntial } \\
\text { LIB } \\
\text { Os }\end{array}$} & \multicolumn{2}{|c|}{$\begin{array}{l}\text { 6) Potential } \\
\text { LIBOs with } \\
\text { debt } \\
\text { information }\end{array}$} & \multicolumn{2}{|c|}{$\begin{array}{l}\text { 7) LIBOs } \\
\text { with more } \\
\text { than } 30 \% \\
\text { assumed } \\
\text { liability to } \\
\text { transaction } \\
\text { value }\end{array}$} & \multicolumn{2}{|c|}{$\begin{array}{l}8 \text { 8) LIBOs } \\
\text { with more } \\
\text { than } 50 \% \\
\text { assumed } \\
\text { liability to } \\
\text { transaction } \\
\text { value }\end{array}$} \\
\hline & & \# & $\%$ & $\#$ & $\%$ & $\#$ & $\%$ & & \# & $\%$ & \# & $\%$ & \# & $\%$ \\
\hline 2005 & 1 & 1 & 100 & 1 & 100 & 1 & 100 & 14 & 12 & 86 & 12 & 100 & 11 & 92 \\
\hline 2004 & 5 & 3 & 60 & 3 & 100 & 3 & 100 & 7 & 4 & 57 & 3 & 75 & 2 & 50 \\
\hline 2003 & 24 & 14 & 58 & 14 & 100 & 10 & 71 & 7 & 2 & 29 & 2 & 100 & 2 & 100 \\
\hline 2002 & 12 & 10 & 83 & 10 & 100 & 7 & 70 & 2 & 2 & 100 & 2 & 100 & 1 & 50 \\
\hline 2001 & 16 & 10 & 63 & 10 & 100 & 8 & 80 & 7 & 2 & 29 & 2 & 100 & 2 & 100 \\
\hline 2000 & 23 & 12 & 52 & 11 & 92 & 10 & 83 & 24 & 17 & 71 & 15 & 88 & 11 & 65 \\
\hline 1999 & 29 & 10 & 34 & 10 & 100 & 9 & 90 & 25 & 17 & 68 & 17 & 100 & 13 & 76 \\
\hline 1998 & 13 & 5 & 38 & 5 & 100 & 5 & 100 & 16 & 10 & 63 & 10 & 100 & 9 & 90 \\
\hline 1997 & 14 & 8 & 57 & 7 & 88 & 4 & 50 & 12 & 5 & 42 & 5 & 100 & 2 & 40 \\
\hline 1996 & 14 & 6 & 43 & 6 & 100 & 4 & 67 & 5 & 3 & 60 & 3 & 100 & 2 & 67 \\
\hline 1995 & 9 & 1 & 11 & 1 & 100 & 0 & 0 & 3 & 0 & 0 & 0 & 0 & 0 & 0 \\
\hline 1994 & 6 & 2 & 33 & 2 & 100 & 2 & 100 & 1 & 1 & 100 & 1 & 100 & 1 & 100 \\
\hline 1993 & 6 & 1 & 17 & 1 & 100 & 1 & 100 & 4 & 0 & 0 & 0 & 0 & 0 & 0 \\
\hline 1992 & 5 & 3 & 60 & 3 & 100 & 3 & 100 & 3 & 0 & 0 & 0 & 0 & 0 & 0 \\
\hline 1991 & 8 & 2 & 25 & 2 & 100 & 1 & 50 & 1 & 0 & 0 & 0 & 0 & 0 & 0 \\
\hline 1990 & 8 & 5 & 63 & 5 & 100 & 5 & 100 & 1 & 0 & 0 & 0 & 0 & 0 & 0 \\
\hline 1989 & 25 & 13 & 52 & 13 & 100 & 10 & 77 & 0 & 0 & 0 & 0 & 0 & 0 & 0 \\
\hline 1988 & 74 & 34 & 46 & 33 & 97 & 31 & 91 & 0 & 0 & 0 & 0 & 0 & 0 & 0 \\
\hline 1987 & 43 & 18 & 42 & 18 & 100 & 15 & 83 & 0 & 0 & 0 & 0 & 0 & 0 & 0 \\
\hline 1986 & 44 & 13 & 30 & 13 & 100 & 11 & 85 & 0 & 0 & 0 & 0 & 0 & 0 & 0 \\
\hline 1985 & 29 & 10 & 34 & 9 & 90 & 8 & 80 & 0 & 0 & 0 & 0 & 0 & 0 & 0 \\
\hline Total & 411 & 181 & 44 & 177 & 98 & 148 & 82 & 132 & 75 & 57 & 72 & 96 & 56 & 78 \\
\hline
\end{tabular}

Note: This study compares the background variables between the sample "LMBOS/LIBOs with more than $30 \%$ assumed liability to transaction value" and the sample "potential LMBOS/LIBOs with debt information disclosed (Column 2\&6)". Using univariate analysis, this study finds insignificant differences in the background variables between them. 
Table 3.5 shows that there are 411 potential LMBOs and 132 potential LIBOs obtained over the period 1985-2005 after Step 2 of LBO sampling procedure. Among these firms, there are $44 \%$ of potential LMBOs with debt information disclosed and $57 \%$ of potential LIBOs with debt information disclosed. Finally, there are 177 LMBOs and 72 LIBOs obtained for the sample of this study, based on the requirement of $30 \%$ minimum assumed liability-transaction value ratio. ${ }^{40}$

\subsubsection{Data Sources}

The sample for this study is derived principally from SDC Thomas Financial Database, Compustat Database, SEC Filings \& Forms (EDGAR), and Factiva Database (which includes Wall Street Journal): 1) SDC Thomas Financial Database: This study collects data on most of the firm-specific and deal-specific variables and on the premiums paid for LMBO and LIBO transactions from SDC Thomas Financial Database. 2) Compustat Database: This database is mainly used to obtain 1-1 matched control firms and to collect data on all the firm-specific variables of the control firms. In addition, the data on some firm-specific variables for LBO firms is also collected from this database. These variables include 3 year average dividend payout ratio, volatility of cash flow, and relative $\mathrm{P} / \mathrm{E}$ ratio for $\mathrm{LBO}$ firms. The missing data on the other variables in the SDC Thomas Financial Database is also added by the corresponding data from the Compustat Database. 3) SEC Filings \& Forms (EDGAR) and Factiva Database: Statements

\footnotetext{
${ }^{40}$ In addition to this criterion, this study also follows Halpern et al (1999)'s criterion of $50 \%$ of assumed liabilitytransaction value ratio and use the LMBO and LIBO sample obtained this way for some of the tests in this study as robustness checks. This study obtains similar results for most of these tests (results not reported), thus the arbitrary cutoff of debt financing in this study does not have great impacts on the results.
} 
describing the buyouts such as Proxy, 8K, 10K, 13E, and 14D are available on SEC Filings \& Forms $\left(\right.$ EDGAR) ${ }^{41}$ or Factiva Database. The amount of assumed liability of each LBO deal is mainly collected from the buyout statement. Pre-buyout level of managerial ownership of LBO is collected from SEC Filings \& Forms (EDGAR). ${ }^{42}$ Data source of each variable used in this study is summarized in Table 3.6.

\section{Table 3.6 Data Sources of This Study}

Panel A: Data Source of Firm-specific Variables

Firms' financial variables include "Volatility of cash flow", "Undistributed free cash flow", "Tax expenditures", "Relative P/E", "Investment opportunities", "Dividend payout ratio", and "Managerial ownership".

\begin{tabular}{|c|c|c|c|}
\hline Variable & Proxy & $\begin{array}{l}\text { Data source for } \\
\text { LBOs }\end{array}$ & $\begin{array}{l}\text { Data source } \\
\text { for industry } \\
\text { peer firms }\end{array}$ \\
\hline $\begin{array}{l}\text { Volatility of } \\
\text { cash flow }\end{array}$ & $\begin{array}{l}\text { Five years' standard deviation of the quarterly } \\
\text { EBITDA/Sales of LBOs prior to LBO } \\
\text { announcement }\end{array}$ & Compustat & Compustat \\
\hline \multirow{2}{*}{$\begin{array}{l}\text { Undistributed } \\
\text { free cash flow } \\
\text { (1 year prior to } \\
\text { LBO } \\
\text { announcement) }\end{array}$} & (EBITDA-Tax-Interests-Dividends)/Net Sales & \multirow{2}{*}{$\begin{array}{l}\text { SDC \& Compustat } \\
\text { (Interests, Capital } \\
\text { Expenditures, and } \\
\text { Net Change in } \\
\text { Working Capital } \\
\text { are from } \\
\text { Compustat) }\end{array}$} & \multirow[t]{2}{*}{ Compustat } \\
\hline & $\begin{array}{l}\text { (EBITDA-Tax-Interests-Dividends-Capital } \\
\text { Expenditures-Net Change in Working Capital) } \\
\text { /Net Sales }\end{array}$ & & \\
\hline $\begin{array}{l}\text { Tax } \\
\text { expenditures ( } 1 \\
\text { year prior to } \\
\text { LBO } \\
\text { announcement) }\end{array}$ & (Tax Expenditures- Deferred Tax)/ Net Sales & SDC & Compustat \\
\hline Relative P/E & $\begin{array}{l}\text { Ratio of an LBO company's P/E and an industry } \\
\text { peer group's P/E }\end{array}$ & Compustat & Compustat \\
\hline $\begin{array}{l}\text { Investment } \\
\text { opportunities }\end{array}$ & Tobin's Q & SDC & Compustat \\
\hline $\begin{array}{l}\text { Dividend } \\
\text { payout ratio }\end{array}$ & $\begin{array}{l}\text { Three-year averaged dividend payout ratio } \\
\text { immediately preceding the announcement of } \\
\text { LIBO or LMBO announcement }\end{array}$ & Compustat & Compustat \\
\hline $\begin{array}{l}\text { Managerial } \\
\text { ownership }\end{array}$ & $\begin{array}{l}\text { The percentage of voting stock held by officers } \\
\text { and directors of the company }\end{array}$ & $\begin{array}{l}\text { Annual report on } \\
\text { Edgar till } 1995\end{array}$ & Compustat \\
\hline
\end{tabular}

\footnotetext{
${ }^{41}$ http://www.sec.gov/edgar.shtml. However, this search allows retrieving only the most recent day's EDGAR filings (from 1994 through 2006). For the LBO deals prior to year 1994, this study can only check Factiva to obtain data on assumed liability of LBO transactions.

${ }^{42}$ For the LBO deals prior to year 1994, managerial ownership data is unfortunately unavailable on SEC Filings \& Forms (EDGAR).
} 
Panel B: Data Source of Deal-specific Variables

Deal specific variables include "Challenged deals", "Deal size", "Assumed liability/Transaction value", "Multiplier", "Ratio of total deal fees and total capital" and "LBO premiums".

\begin{tabular}{|l|l|l|}
\hline Variable & Proxy & Data Source for LBOs \\
\hline Challenged deals & $\begin{array}{l}\text { '1' where a third party launched an offer for the target while } \\
\text { this original bid was pending; "0" otherwise }\end{array}$ & SDC \\
\hline Deal size & $\begin{array}{l}\text { Transaction value (total value of consideration paid by the } \\
\text { acquirers, excluding fees and expenses) }\end{array}$ & SDC \\
\hline $\begin{array}{l}\text { Assumed liability- } \\
\text { transaction value } \\
\text { ratio }\end{array}$ & Assumed liability/Transaction value & $\begin{array}{l}\text { SDC \& buyout } \\
\text { statements on Factiva } \\
\text { or Edgar }\end{array}$ \\
\hline Multiplier & $\begin{array}{l}\text { Transaction value/EBITDA 1 year prior to LBO } \\
\text { announcement }\end{array}$ & $\begin{array}{l}\text { SDC and buyout } \\
\text { statements }\end{array}$ \\
\cline { 1 - 2 } $\begin{array}{l}\text { Ratio of total deal } \\
\text { fees and total } \\
\text { transaction value }\end{array}$ & Total deal fees/Total transaction value & SDC \\
\cline { 1 - 2 } LBO Premiums & $\begin{array}{l}\text { ((Offer Price - Stock Price 1 Week Prior to Announcement) } \\
\text { /Stock Price 1 Week Prior to Announcement)* 100) }\end{array}$ & SDC \\
\cline { 2 - 2 } & $\begin{array}{l}\text { ((Offer Price - Stock Price 1 Day Prior to Announcement) / } \\
\text { Stock Price 1 Day Prior to Announcement) *100) }\end{array}$ & \\
\cline { 2 - 3 } & $\begin{array}{l}\text { ((Offer Price - Stock Price 4 Weeks Prior to } \\
\text { Announcement) / Stock Price 4 Weeks Prior to } \\
\text { Announcement) * 100) }\end{array}$ & \\
\hline
\end{tabular}

\subsubsection{Descriptive Statistics of LIBO and LMBO Sample}

To provide a general picture, distributions of U.S. LIBO and LMBO transactions by year over the period 1985-2005 are presented in Table 3.7. Further, descriptive statistics of deal-specific and firm-specific variables of LIBOs and LMBOs are presented in Table 3.8. The important observations in the changing LBO deal characteristics based on an initial dataset of LIBOs and LMBOs over the period 1985-2005 are described in Appendix D.

\footnotetext{
${ }^{43}$ Transaction value is updated based on the buyout statements on Factiva or Edgar.
} 
Table 3.7 Yearly Distribution of U.S. LBO Transactions over the Period 1985-2005

"\# of Transaction" is calculated based the firms satisfying the LBO definition of this study. "Total transaction value" is calculated by total amount of transaction value of all the deals satisfying LBO definition of this study. "Average deal size" in this table implies the average transaction value of LMBOs and LIBOs by year.

\begin{tabular}{|c|c|c|c|c|c|c|}
\hline \multirow[b]{2}{*}{ Year } & \multicolumn{2}{|c|}{ \# of Transactions } & \multicolumn{2}{|c|}{$\begin{array}{l}\text { Total Transaction Value (in } \$ \\
\text { mil. US dollars) }\end{array}$} & \multicolumn{2}{|c|}{$\begin{array}{l}\text { Average Deal Size (in } \$ \text { mil. US } \\
\text { dollars) }\end{array}$} \\
\hline & LIBO & LMBO & LIBO & LMBO & LIBO & LMBO \\
\hline 1985 & 0 & 9 & & 13102.80 & & 1455.87 \\
\hline 1986 & 0 & 13 & & 5980.58 & & 460.04 \\
\hline 1987 & 0 & 18 & & 15569.35 & & 864.96 \\
\hline 1988 & 0 & 33 & & 17797.29 & & 539.31 \\
\hline 1989 & 0 & 13 & & 6811.38 & & 523.95 \\
\hline 1990 & 0 & 5 & & 1342.50 & & 268.50 \\
\hline 1991 & 0 & 2 & & 32.13 & & 16.07 \\
\hline 1992 & 0 & 3 & & 52.73 & & 17.58 \\
\hline 1993 & 0 & 1 & & 94.33 & & 94.33 \\
\hline 1994 & 1 & 2 & 349.23 & 86.74 & 349.23 & 43.37 \\
\hline 1995 & 0 & 1 & & 2436.21 & & 2436.21 \\
\hline 1996 & 3 & 6 & 760.09 & 2435.96 & 253.36 & 405.99 \\
\hline 1997 & 5 & 7 & 4918.38 & 1496.70 & 983.68 & 213.81 \\
\hline 1998 & 10 & 5 & 4685.97 & 1026.54 & 468.60 & 205.31 \\
\hline 1999 & 17 & 10 & 7398.79 & 3351.30 & 435.22 & 335.13 \\
\hline 2000 & 15 & 11 & 6684.06 & 2563.80 & 445.60 & 233.07 \\
\hline 2001 & 2 & 10 & 2250.70 & 1173.54 & 1125.35 & 117.35 \\
\hline 2002 & 2 & 10 & 1060.19 & 3283.15 & 530.09 & 328.32 \\
\hline 2003 & 2 & 14 & 501.29 & 1036.41 & 250.65 & 74.03 \\
\hline 2004 & 3 & 3 & 7772.58 & 212.38 & 2590.86 & 70.79 \\
\hline 2005 & 12 & 1 & 19894.42 & 3400.00 & 1657.87 & 3400.00 \\
\hline Total & 72 & 177 & $56,275.7$ & $83,285.82$ & N/A & N/A \\
\hline
\end{tabular}

Note: The sample size for LMBOs is larger than LIBOs over the period 1985-2005. However, there are no challenges comparing the deal characteristics between $L M B O$ s and LIBOs over each sub period, since they have similar sample size over each sub period (i.e. 1995-1999 and 2000-2005). 
Table 3.8 Descriptive Statistics of Deal-specific Variables and Firm-specific Variables for LIBOs and LMBOs over the Period 1985-2005 (Median)

Panel A: Yearly Descriptive Statistics of Deal-specific Variables for LMBOs and LIBOs (Median)

"Cross-country deal" is " 1 " if the target and acquirer are not in the same country and " 0 " otherwise. The medians of the variables by year are presented as follows. "Challenged deal" is " 1 " where a third party launched an offer for the target while this original bid was pending and "0" otherwise.

\begin{tabular}{|c|c|c|c|c|c|c|c|c|c|c|c|c|}
\hline & $\begin{array}{l}\text { \# of } \\
\text { Trar } \\
\text { ns }\end{array}$ & actio & \begin{tabular}{|l|} 
Transa \\
Value/ \\
A \\
\end{tabular} & tion & $\begin{array}{l}\text { Premiu } \\
\text { week }\end{array}$ & & $\begin{array}{l}\text { Assum } \\
\text { Liabili } \\
\text { action }\end{array}$ & $\begin{array}{l}\text { d } \\
y / \text { Trans } \\
\text { lalue }\end{array}$ & $\begin{array}{l}\text { Challe } \\
\text { deal or }\end{array}$ & & $\begin{array}{l}\text { Cross- } \\
\text { deal \% }\end{array}$ & ountry \\
\hline Year & $\begin{array}{l}\text { LM } \\
\text { BO } \\
\end{array}$ & \begin{tabular}{|l|} 
LIB \\
$\mathrm{O}$ \\
\end{tabular} & \begin{tabular}{|l|} 
LMB \\
$\mathrm{O}$ \\
\end{tabular} & LIBO & $\begin{array}{l}\text { LMB } \\
\mathrm{O} \\
\end{array}$ & LIBO & $\begin{array}{l}\text { LMB } \\
\mathrm{O}\end{array}$ & LIBO & $\begin{array}{l}\text { LMB } \\
\mathrm{O}\end{array}$ & LIBO & $\begin{array}{l}\text { LMB } \\
\mathrm{O}\end{array}$ & LIBO \\
\hline 1985 & 9 & & 8.14 & & 31.82 & & 0.78 & & 33.33 & & 0.00 & \\
\hline 1986 & 13 & & 6.67 & & 37.50 & & 0.76 & & 30.77 & & 0.00 & \\
\hline 1987 & 18 & & 7.14 & & 36.38 & & 0.91 & & 50.00 & & 0.00 & \\
\hline 1988 & 33 & & 7.41 & & 40.00 & & 0.82 & & 6.06 & & 0.00 & \\
\hline 1989 & 13 & & 6.10 & & 41.14 & & 0.68 & & 38.46 & & 0.00 & \\
\hline 1990 & 5 & & 2.43 & & 36.99 & & 0.75 & & 20.00 & & 20.00 & \\
\hline 1991 & 2 & & 5.62 & & 40.74 & & 0.53 & & 0.00 & & 0.00 & \\
\hline 1992 & 3 & & 3.88 & & 4.76 & & 0.82 & & 0.00 & & 0.00 & \\
\hline 1993 & 1 & & 7.20 & & 36.36 & & 0.65 & & 0.00 & & 0.00 & \\
\hline 1994 & 2 & 1 & 11.59 & 17.46 & 57.66 & 24.49 & 0.90 & 1.00 & 0.00 & 0.00 & 0.00 & 0.00 \\
\hline 1995 & 1 & & 10.12 & & 0.62 & & 0.45 & & 0.00 & & 0.00 & \\
\hline 1996 & 6 & 3 & 4.32 & 16.28 & 28.20 & 28.00 & 0.54 & 0.70 & 33.33 & 0.00 & 16.67 & 0.00 \\
\hline 1997 & 7 & 5 & 8.48 & 16.93 & 37.16 & 13.40 & 0.61 & 0.42 & 0.00 & 0.00 & 0.00 & 0.00 \\
\hline 1998 & 5 & 10 & 7.21 & 4.69 & 14.29 & 13.29 & 0.91 & 0.75 & 0.00 & 10.00 & 0.00 & 0.00 \\
\hline 1999 & 10 & 17 & 7.71 & 6.74 & 28.84 & 29.09 & 0.87 & 0.62 & 0.00 & 0.00 & 10.00 & 5.88 \\
\hline 2000 & 11 & 15 & 3.95 & 6.11 & 40.33 & 44.29 & 0.75 & 0.65 & 18.18 & 6.67 & 0.00 & 5.88 \\
\hline 2001 & 10 & 2 & 4.95 & 18.62 & 38.95 & 39.57 & 0.92 & 0.64 & 10.00 & 0.00 & 0.00 & 0.00 \\
\hline 2002 & 10 & 2 & 4.62 & 8.20 & 31.89 & 37.77 & 0.66 & 0.51 & 10.00 & 0.00 & 0.00 & 0.00 \\
\hline 2003 & 14 & 2 & 3.59 & 8.64 & 65.40 & 40.85 & 0.63 & 0.77 & 7.14 & 0.00 & 0.00 & 0.00 \\
\hline 2004 & 3 & 3 & 5.56 & 14.87 & 17.92 & 26.29 & 0.61 & 0.80 & 0.00 & 0.00 & 0.00 & 0.00 \\
\hline 2005 & 1 & 12 & 7.87 & 12.21 & 23.68 & 23.87 & 0.72 & 0.76 & 0.00 & 16.67 & 0.00 & 0.00 \\
\hline $\begin{array}{r}1985- \\
2005\end{array}$ & 171 & 72 & 6.41 & 7.48 & 32.89 & 27.16 & 0.73 & 0.66 & 12.25 & 3.03 & 2.22 & 1.07 \\
\hline
\end{tabular}


Panel B: Descriptive Statistics of Firm-specific Variables for LMBOs and LIBOs over the Period 1985-2005

The numbers in the following table is normalized in 2005 dollars to ensure that the annual variations in the two subsamples (LIBOs and LMBOs) do not influence these numbers.

\begin{tabular}{|c|c|c|c|c|c|c|}
\hline \multirow[t]{2}{*}{ Variable } & \multicolumn{2}{|l|}{ Mean } & \multicolumn{2}{|l|}{ Median } & \multicolumn{2}{|c|}{ Std. Deviation } \\
\hline & LIBO & LMBO & LIBO & LMBO & LIBO & LMBO \\
\hline Deal Size (in \$ mil. US dollars) & 798.82 & 578.43 & 411.72 & 150.54 & 927.47 & 921.62 \\
\hline Target Total Assets (in \$ mil. US dollars) & 837.75 & 612.72 & 398.45 & 176.47 & 936.65 & 1039.79 \\
\hline $\begin{array}{l}\text { Premium } 1 \text { week prior to announcement date } \\
(\%)\end{array}$ & 33.23 & 42.20 & 27.36 & 36.85 & 28.81 & 29.98 \\
\hline Investment Opportunities (Tobin's Q) & 1.96 & 1.50 & 1.46 & 1.31 & 1.73 & 0.89 \\
\hline Assumed liability / Transaction value & 0.76 & 0.89 & 0.65 & 0.74 & 0.48 & 1.08 \\
\hline Volatility of Cash Flow & 4.83 & 8.87 & 3.26 & 4.60 & 4.71 & 13.99 \\
\hline $\begin{array}{l}\text { Scaled undistributed Free Cash (in \$ mil. US } \\
\text { dollars) }\end{array}$ & 0.08 & 0.05 & 0.07 & 0.06 & 0.10 & 0.19 \\
\hline $\begin{array}{l}\text { Scaled Tax Expenditures (in } \$ \text { mil. US } \\
\text { dollars) }\end{array}$ & 0.02 & 0.02 & 0.02 & 0.02 & 0.03 & 0.02 \\
\hline 3 Year Average Dividend Payout Ratio & 5.45 & 8.87 & 0.00 & 0.00 & 17.71 & 29.79 \\
\hline Transaction value/ EBITDA & 8.77 & 7.46 & 7.39 & 6.49 & 5.60 & 6.09 \\
\hline
\end{tabular}




\section{CHAPTER 4: RESULTS: CHANGES IN LBO DEAL CHARACTERISTICS}

This chapter describes the empirical results of this study on how LIBO and LMBO deal characteristics have evolved over the period 1985-2005. Subsequently, Section 4.1 and 4.2 describes the changing deal characteristics of LMBOs (over the period 1985-2005) and LIBOs (over the period 1995-2005) correspondingly. Section 4.3 describes the results for the differences in overall deal characteristics between LMBOs and LIBOs over the two sub periods 1995-1999 and 2000-2005.

\subsection{Changes in LMBO Deal Characteristics over Time}

This section describes the results for the changing deal characteristics of LMBOs over the study period 1985-2005. The results using a three-group (representing 1985-1989, 19901999, and 2000-2005) 1-way MANOVA analysis are presented in Table 4.1. 
Table 4.1: Three-group (representing 1985-1989, 1990-1999, and 2000-2005) 1-way MANOVA Analysis for LMBOs

"Deal Size", "Multiplier (Transaction Value/EBITDA)", "Premiums 1 Week prior to LBO Announcement", "Investment Opportunities (Tobin's Q)", "Assumed Liability / Transaction Value", "Scaled Undistributed Free Cash Flow", "Scaled Tax Expenditures" "3 Year Average Dividend Payout Ratio" and "Total Deal Fee/ Transaction Value" are included in the following MANOVA analysis as dependent variables.

"Managerial Ownership", "Relative P/E", and "Volatility of Cash Flow" are not included in the analyses presented below, since there is a very limited number of LMBOs with the data on these variables available over 1985-1989.

"Time dummy" is included as independent variable. Time dummy is set as "-1" for the sub period 1985-1989, "0" for the sub period 1990-1999, and "1" for the sub period 2000-2005.

Outliers are detected using Weisberg t-test statistic. Some outliers are deleted after careful assessments as there are some values that seem documented wrongly in the database or are too high or low to make any financial sense.

The results reported subsequently are obtained using "(EBITDA-Tax-Interests-Dividends)/Net Sales" as the proxy for the pre-buyout level of free cash flow and using "Premiums 1 Week prior to LBO Announcement" as the proxy for the LBO premiums.

Panel A: Descriptive Analysis

\begin{tabular}{lllll}
\hline & N & Sub period & Mean & Std. Deviation \\
\hline Deal Size (in \$ mil. US dollars) & 75 & $1985-1989$ & 606.69 & 1003.94 \\
& 38 & $1990-1999$ & 320.59 & 547.62 \\
& 43 & $2000-2005$ & 258.15 & 601.51 \\
\hline Multiplier (Transaction Value/EBITDA) & 75 & $1985-1989$ & 6.93 & 12.93 \\
& 38 & $1990-1999$ & 7.62 & 4.25 \\
& 43 & $2000-2005$ & 5.64 & 8.31 \\
\hline Premiums 1 Week prior to LBO & 75 & $1985-1989$ & 44.54 & 28.07 \\
Announcement & 38 & $1990-1999$ & 30.45 & 24.08 \\
& 43 & $2000-2005$ & 49.64 & 34.61 \\
\hline Investment Opportunities (Tobin's Q) & 75 & $1985-1989$ & 2.28 & 5.00 \\
& 38 & $1990-1999$ & 1.65 & 0.97 \\
\hline Assumed Liability / Transaction Value & 73 & $2000-2005$ & 0.80 & 0.89 \\
\hline Scaled Undistributed Free Cash Flow & 38 & $1985-1989$ & 0.86 & 0.41 \\
& 43 & $1990-1999$ & 0.80 & 0.50 \\
\hline Scaled Tax Expenditures & 75 & $1985-1989$ & 0.03 & 0.56 \\
\hline Total Deal Fess/Total Transaction Value & 78 & $1990-1999$ & 0.07 & 0.21 \\
& 43 & $2000-2005$ & 0.04 & 0.18 \\
\hline Year Average Dividend Payout Ratio & 75 & $1985-1989$ & 0.03 & 0.03 \\
& 38 & $1990-1999$ & 0.06 & 0.22 \\
\hline
\end{tabular}

Panel B: Three-group 1-way MANOVA Analysis

\begin{tabular}{llllll}
\hline Hotelling's Trace & Value & F & Hypothesis df & Error df & Sig. \\
\hline Intercept & & & & & \\
Time dummy & 6.72 & 122.56 & 8 & 146 & $0.000^{* * *}$ \\
\hline
\end{tabular}

Note (1):*,**, and *** indicates statistical significance at $10 \%, 5 \%$, and $1 \%$ levels respectively.

(2): This study obtains similar results when including managerial ownership, though it greatly reduces the sample size of LMBOs for the sub period 1985-1989.

(3): This study obtains similar result using an alternate measure of pre-buyout level of free cash flow (Cash Flow from Operations-Capital Expenditure-Net changes in working capital)/Net Sales. 
Panel C: Multiple Comparisons

The probability levels are controlled to account for the multiple comparison tests and Bonferroni multiple comparison procedure is used.

\begin{tabular}{llllll}
\hline & (1) Group3 & (2) Group3 & $\begin{array}{l}\text { Mean Difference } \\
(1-2)\end{array}$ & Std. Error & Sig. \\
& & & & & \\
& & & & 161.68 & 0.236 \\
& $1985-1989$ & $1990-1999$ & 286.10 & 155.32 & 0.079 \\
& $1985-1989$ & $2000-2005$ & $348.54^{*}$ & 180.79 & 1.000 \\
\hline Deal Size & $1990-1999$ & $2000-2005$ & 62.44 & 2.03 & 1.000 \\
Vultiplier (Transaction & $1985-1989$ & $1990-1999$ & -0.69 & 1.95 & 1.000 \\
& $1985-1989$ & $2000-2005$ & 1.29 & 2.27 & 1.000 \\
\hline Premiums 1 Week prior & $1990-1999$ & $2000-2005$ & 1.98 & 5.81 & 0.049 \\
to LBO Announcement & $1985-1989$ & $1990-1999$ & $14.10^{* *}$ & 5.58 & 1.000 \\
& $1990-1999$ & $2000-2005$ & -5.09 & 6.49 & 0.011 \\
\hline Investment Opportunities & $1985-1989$ & $19000-2005$ & $-19.19 * *$ & 0.71 & 1.000 \\
(Tobin's Q) & $1985-1989$ & $2000-2005$ & 0.63 & 0.68 & 0.093 \\
& $1990-1999$ & $2000-2005$ & $0.84 *$ & 0.79 & 0.859 \\
\hline Assumed liability & $1985-1989$ & $1990-1999$ & 0.06 & 0.09 & 1.000 \\
Transaction Value & $1985-1989$ & $2000-2005$ & 0.04 & 0.09 & 1.000 \\
& $1990-1999$ & $2000-2005$ & -0.02 & 0.11 & 1.000 \\
\hline Scaled Undistributed & $1985-1989$ & $1990-1999$ & -0.04 & 0.04 & 0.994 \\
Free Cash Flow & $1985-1989$ & $2000-2005$ & -0.01 & 0.04 & 1.000 \\
& $1990-1999$ & $2000-2005$ & 0.03 & 0.05 & 1.000 \\
\hline Scaled Tax Expenditures & $1985-1989$ & $1990-1999$ & -0.04 & 0.02 & 0.267 \\
& $1985-1989$ & $2000-2005$ & 0.01 & 0.02 & 1.000 \\
& $1990-1999$ & $2000-2005$ & 0.05 & 0.02 & 0.124 \\
\hline 3 Year Average Dividend & $1985-1989$ & $1990-1999$ & -0.18 & 9.75 & 1.000 \\
Payout Ratio & $1985-1989$ & $2000-2005$ & 12.39 & 0.36 & 0.563 \\
\hline Total Deal Fess/Total & $1990-1999$ & $2000-2005$ & 12.57 & 0.00 & 0.752 \\
\hline Transaction Value & $1985-1989$ & $1990-1999$ & $0.01 * *$ & 0.050 \\
\hline & $1985-1989$ & $2000-2005$ & 0.01 & 1.000 \\
\hline
\end{tabular}

Note (1): *,**, and *** indicates statistical significance at $10 \%, 5 \%$, and $1 \%$ levels respectively.

(2): This study obtains similar results using an alternate measure of pre-buyout level of free cash flow (Cash Flow from Operations-Capital Expenditure-Net changes in working capital)/Net Sales.

Panel B of Table 4.1 shows that the coefficient for the time dummy variable is significant in the above MANOVA analysis. This finding suggests that there are statistically significant differences in overall deal characteristics of LMBOs among the three sub periods, namely, 1985-1989, 1990-1999, and 2000-2005. In other words, this implies that LMBO deal characteristics had greatly changed over the period 1985-2005. Hypothesis $\mathrm{C} 1$ is thus supported. 
Through multiple comparisons, this study further finds that deal size, LBO premiums, investment opportunities, and total deal fess/total transaction value mainly contribute to the overall differences in deal characteristics of LMBOs among the three sub periods (Results are presented in Panel $\mathrm{C}$ of Table 4.1). Interestingly, this study finds insignificant differences in LMBO premiums between 1985-1989 and 2000-2005. Moreover, the premiums paid for LMBOs over 1985-1989 and 2000-2005 are significantly higher than over the sub period 1990-1999. This implies that acquirers were willing to pay as high premiums for LMBO targets over $2000-2005$ as in the late 1980 s.

To further explore the possibility that the LBO market was overheated in $2000-2005$, this study directly compares the deal characteristics of LMBOs between 1985-1989 and 20002005. Corresponding results are presented in Table 4.2. 
Table 4.2 T-tests for Comparisons in Deal Characteristics between LMBOs over the 1985-1989 and LMBOs over the 2000-2005

"Deal Size", "Multiplier (Transaction Value/EBITDA)", "Premiums 1 Week prior to LBO Announcement", "Investment Opportunities (Tobin's Q)", "Assumed Liability / Transaction Value", "Scaled Undistributed Free Cash Flow", "Scaled Tax Expenditures" "3 Year Average Dividend Payout Ratio" and "Total Deal Fee/ Transaction Value" are included in the following t-tests.

"Managerial Ownership", "Relative P/E", and "Volatility of Cash Flow" are not included in the analyses presented below, since there is a very limited number of LMBOs with the data on these variables available over 1985-1989.

The results reported subsequently are obtained using "(EBITDA-Tax-Interests-Dividends)/Net Sales" as the proxy for the pre-buyout level of free cash flow and using "Premiums 1 Week prior to LBO Announcement" as the proxy for the LBO premiums.

\begin{tabular}{llll}
\hline & $\begin{array}{l}\text { Mean Difference } \\
(1985-1989)-(2000-\end{array}$ & t-stat & Sig. \\
& $2005)$ & & \\
\hline Deal Size & $417.72^{* * *}$ & 2.40 & 0.02 \\
Multiplier (Transaction Value/EBITDA) & 1.63 & 0.83 & 0.41 \\
Premiums 1 Week prior to LBO Announcement & -6.70 & -1.17 & 0.24 \\
Investment Opportunities (Tobin's Q) & $0.76^{* * *}$ & 5.07 & 0.01 \\
Assumed Liability / Transaction Value & -0.25 & -1.18 & 0.24 \\
Scaled Undistributed Free Cash Flow & -0.01 & -0.49 & 0.62 \\
Scaled Tax Expenditures & $0.01^{* *}$ & 2.69 & 0.02 \\
3 Year Average Dividend Payout Ratio & 11.45 & 0.89 & 0.37 \\
Total Deal Fee/ Transaction Value & $0.01^{* *}$ & 2.03 & 0.05 \\
\hline
\end{tabular}

Note (1): *,**, and *** indicates statistical significance at $10 \%, 5 \%$, and $1 \%$ levels respectively.

(2): This study obtains similar results using an alternate measure of pre-buyout level of free cash flow (Cash Flow from Operations-Capital Expenditure-Net changes in working capital)/Net Sales.

Table 4.2 shows that there are no significant differences between 1985-1989 and 20002005 in the following LMBO deal characteristics variables: multiplier (transaction value/EBITDA), LBO premiums, assumed liability/transaction value, free cash flow, and dividend payout ratio. In addition, LMBO deals over the sub period 2000-2005 are found to have significantly smaller deal sizes, less investment opportunities, less tax expenditures, and less percentage of total deal fees than those in the late 1980s. Overall, these results imply that the key deal characteristics of LMBOs over the sub period 20002005 (i.e. prices, financial conditions, and buyout capital structures) are not significantly different from those in the late 1980s. 


\subsection{Changes in LIBO Deal Characteristics over Time}

This section describes the results for changing deal characteristics of LIBOs over the

period 1995-2005. The results using a two-group (representing the two sub periods 1995-

1999 and 2000-2005) 1-way MANOVA analysis are presented in Table 4.3.

\section{Table 4.3: 2-group (representing 1995-1999 and 2000-2005) 1-way MANOVA Analysis for LIBOs}

"Deal Size", "Multiplier (Transaction Value/EBITDA)", "Premiums 1 Week prior to LBO Announcement", "Investment Opportunities (Tobin's Q)", "Assumed Liability / Transaction Value", "Scaled Undistributed Free Cash Flow", "Scaled Tax Expenditures" "3 Year Average Dividend Payout Ratio", "Managerial Ownership", "Relative P/E", "Volatility of Cash Flow", and "Total Deal Fee/ Transaction Value" are included in the following MANOVA analysis as dependent variables. Time dummy is included as independent variable. Time dummy is set as "1" if an LIBO and LMBO occurred over the period 1995-1999 and as "0" over the period 2000-2005.

Outliers are detected using Weisberg t-test statistic. Some outliers are deleted after careful assessments as there are some values that seem documented wrongly in the database or are too high or low to make any financial sense.

The results reported subsequently are obtained using "(EBITDA-Tax-Interests-Dividends)/Net Sales" as the proxy for the pre-buyout level of free cash flow and using "Premiums 1 Week prior to LBO Announcement" as the proxy for the LBO premiums.

Panel A: 2-group (representing 1995-1999 and 2000-2005) 1-way MANOVA on LIBOs over the period 1995-2005

\begin{tabular}{lccccc}
\hline Hotelling's Trace & Value & F & Hypothesis df & Error df & Sig. \\
\hline Intercept & & & & & \\
Time dummy & 2.13 & 5.22 & 11 & 27 & $0.000^{* * *}$ \\
\hline
\end{tabular}

Note (1):*,**, and *** indicates statistical significance at 10\%, 5\%, and $1 \%$ levels respectively.

(2): This study obtains similar results using an alternate measure of pre-buyout level of free cash flow (Cash Flow from Operations-Capital Expenditure-Net changes in working capital)/Net Sales.

Panel B: Univariate analysis for LIBOs between the sub period 2000-2005 and 1995-1999

\begin{tabular}{llll}
\hline & $\begin{array}{l}\text { Mean Difference (1995- } \\
1999-2000-2005)\end{array}$ & t-stat & Sig. \\
\hline Deal Size & $-461.18^{* *}$ & -2.08 & 0.04 \\
Multiplier (Transaction Value/EBITDA) & -0.18 & -0.13 & 0.89 \\
Premiums 1 Week prior to LBO Announcement & -8.63 & -1.23 & 0.22 \\
Investment Opportunities (Tobin's Q) & 0.67 & 1.56 & 0.12 \\
Assumed Liability / Transaction Value & 0.16 & 1.39 & 0.17 \\
Scaled Undistributed Free Cash Flow & -0.38 & -1.14 & 0.26 \\
Scaled Tax Expenditures & -0.01 & -1.40 & 0.17 \\
3 Year Average Dividend Payout Ratio & -3.06 & -0.70 & 0.49 \\
Managerial Ownership & 2.08 & 0.39 & 0.69 \\
Relative P/E & -3.81 & -0.95 & 0.35 \\
Volatility of Cash Flow & -1.28 & -1.06 & 0.29 \\
Total Deal Fee/ Transaction Value & 0.00 & 1.71 & 0.11 \\
\hline
\end{tabular}

Note: $* * *$, and $* * *$ indicates statistical significance at $10 \%, 5 \%$, and $1 \%$ levels respectively. 
Panel A of Table 4.3 shows that deal characteristics of LIBOs had not significantly changed over the period 1995-2005. This result fails to support Hypothesis C2. The follow-up t-tests (presented in Panel B of Table 4.3) further show that deal size of LIBOs is the only variable that differs between 1995-1999 and 2000-2005. Specifically, LIBOs over the sub period 2000-2005 are found to have significantly larger deal size than over the sub period 1995-1999.

\subsection{Differences in Deal Characteristics between LMBOs and LIBOs}

This section describes the differences in deal characteristics between LMBOs and LIBOs over the two sub periods 1995-1999 and 2000-2005. 2-group 1-way MANOVA is performed to compare LIBOs with LMBOs over 1) the sub period 2000-2005 (Results are presented in Panel A of Table 4.4), and 2) the sub-period 1995-1999 (Results are presented in Panel B of Table 4.4). 


\section{Table 4.4 MANOVA Analysis for the Differences in Deal Characteristics between}

LMBOs and LIBOs over the Period 1995-2005

"Deal Size", "Multiplier (Transaction Value/EBITDA)", "Premiums 1 Week prior to LBO Announcement", "Investment Opportunities (Tobin's Q)", “Assumed Liability / Transaction Value", "Scaled Undistributed Free Cash Flow", "Scaled Tax Expenditures" "3 Year Average Dividend Payout Ratio", "Managerial Ownership", "Relative P/E", "Volatility of Cash Flow", and "Total Deal Fee/ Transaction Value" are included in this MANOVA analysis as dependent variables.

"LBO type" is included as independent variable. It is set as "l" if it was an LMBO and as "- 1 "if it was an LIBO. Outliers are detected using Weisberg t-test statistic. Some outliers are then deleted after careful assessments as there are some values that seem documented wrongly in the database or are too high or low to make any financial sense.

The results reported subsequently are obtained using "(EBITDA-Tax-Interests-Dividends)/Net Sales" as the proxy for the pre-buyout level of free cash flow and using "Premiums 1 Week prior to LBO Announcement" as the proxy for the LBO premiums.

Panel A: 2-group (representing LMBOs and LIBOs) 1-way MANOVA over the sub period 2000-2005

\begin{tabular}{llllll}
\hline Hotelling's Trace & Value & F & Hypothesis df & Error df & Sig. \\
\hline Intercept & 14.10 & 56.40 & 11 & 44 & $0.000^{* * *}$ \\
LBO type & 0.75 & 3.01 & 11 & 44 & $0.005^{* * *}$ \\
\hline
\end{tabular}

Note $(1): * * *$, and $* * *$ indicates statistical significance at $10 \%, 5 \%$, and $1 \%$ levels respectively.

(2): This study obtains similar results using an alternate measure of pre-buyout level of free cash flow (Cash Flow from Operations-Capital Expenditure-Net changes in working capital)/Net Sales.

Panel B: 2-group (representing LMBOs and LIBOs) 1-way MANOVA over the sub period 1995-1999

\begin{tabular}{llllll}
\hline Hotelling's Trace & Value & F & Hypothesis $\mathbf{d f}$ & Error $\mathrm{df}$ & Sig. \\
\hline Intercept & & & & & \\
LBO type & 15.32 & 29.25 & 11 & 21 & $0.000^{* * *}$ \\
\hline
\end{tabular}

Note (1):*,**, and *** indicates statistical significance at $10 \%, 5 \%$, and $1 \%$ levels respectively.

(2): This study obtains similar results using an alternate measure of pre-buyout level of free cash flow (Cash Flow from Operations-Capital Expenditure-Net changes in working capital)/Net Sales.

Panel C: Univariate analysis on the differences in deal characteristics between LMBOs and LIBOs over the sub period $2000-2005$

\begin{tabular}{llll}
\hline & $\begin{array}{l}\text { Mean } \\
\text { Difference(LIBO- } \\
\text { LMBO) }\end{array}$ & T-stat & Sig. \\
& & & \\
\hline Deal Size & $585.13^{* * *}$ & 2.67 & 0.01 \\
Multiplier (Transaction Value/EBITDA) & 2.07 & 1.27 & 0.21 \\
Premiums 1 Week prior to LBO & & -1.79 & 0.08 \\
Announcement & $-13.36^{*}$ & 4.12 & 0.00 \\
Investment Opportunities (Tobin's Q) & $0.86^{* * *}$ & -1.23 & 0.22 \\
Assumed Liability / Transaction Value & -0.38 & 1.78 & 0.08 \\
Scaled undistributed Free Cash Flow & $0.05^{*}$ & 2.70 & 0.01 \\
Scaled Tax Expenditures & $0.02^{* * *}$ & -0.74 & 0.46 \\
3 Year Average Dividend Payout Ratio & -29.47 & -4.05 & 0.00 \\
Managerial Ownership & $-17.64^{* * *}$ & 1.43 & 0.16 \\
Relative P/E & 26.35 & -1.18 & 0.24 \\
Volatility of Cash Flow & -18.64 & -1.61 & 0.10 \\
Total Deal Fee/ Transaction Value & $-0.01^{*}$ & & \\
\hline
\end{tabular}

Note: $* * *$, and $* * *$ indicates statistical significance at $10 \%, 5 \%$, and $1 \%$ levels respectively. 
Panel A of Table 4.4 shows that there are significant differences in overall deal characteristics between LIBOs and LMBOs over the sub period 2000-2005. On the contrary, Panel B of Table 4.4 shows that there are no significant differences in overall deal characteristics between LIBOs and LMBOs over the sub period 1995-1999. Thus, Hypothesis C3 is supported over the sub period $2000-2005$, while it is rejected over the sub period 1995-1999.

To further explore the differences in deal characteristics between LIBOs and LMBOs over the sub period 2000-2005, this study performs follow-up t-tests (Results are presented in Panel C of Table 4.5). Compared to LIBOs, LMBOs over the sub period 2000-2005 are found to have significantly smaller deal sizes, higher premiums, less investment opportunities, lower levels of the free cash flows, less tax expenditures, higher levels of managerial ownership, and higher percentage of total deal fees. Overall, these findings imply that LMBOs over the sub period 2000-2005 were in worse financial conditions (i.e. lower levels of free cash flows and less potential tax savings) than LIBOs, but higher premiums were paid for them. This is consistent with the overheated market hypothesis. Additionally, the finding that significantly higher premiums were paid for LMBOs than for LIBOs fails to support the asymmetric information hypothesis. In other words, this implies that the management did not take advantage of other shareholders by intentionally lowering the buyout price in 2000-2005. 


\subsection{Conclusions}

A summary of the results for the research hypotheses on changes in LBO deal characteristics is presented in Table 4.5 .

Table 4.5 Summary of Changes in LBO Deal Characteristics

\begin{tabular}{|l|l|l|}
\hline Hypothesis & Period & Results \\
\hline $\begin{array}{l}\text { Hypothesis C1: There are significant differences in overall deal characteristics } \\
\text { of LMBOs among the sub periods: 1985-1989, 1990-1999, and 2000-2005. }\end{array}$ & $\begin{array}{l}1985- \\
2005\end{array}$ & Supported \\
\hline $\begin{array}{l}\text { Hypothesis C2: There are significant differences in overall deal characteristics } \\
\text { of LIBOs between the sub periods: 1995-1999 and 2000-2005. }\end{array}$ & $\begin{array}{l}1995- \\
2005\end{array}$ & $\begin{array}{l}\text { Not } \\
\text { Supported }\end{array}$ \\
\hline $\begin{array}{l}\text { Hypothesis C3: There are significant differences in overall deal characteristics } \\
\text { between LMBOs and LIBOs over the period 1995-2005. }\end{array}$ & $\begin{array}{l}1995- \\
1999\end{array}$ & $\begin{array}{l}\text { Not } \\
\text { Supported }\end{array}$ \\
\cline { 2 - 4 } & $2000-$ & Supported \\
\hline
\end{tabular}

In conclusion, all the findings for Subtopic 1 are consistent with the hypothesis that the LMBO market was overheated over the sub period 2000-2005. A possible explanation for how LBO market cycle affects the deal characteristics of LBOs is described as follows. When LBO market cooled off in the 1990s, LMBOs and LIBOs had similar deal characteristics. However, as LBO market was heating up over the sub period 2000-2005, LMBOs became more aggressively priced and, at the same time, they were in worse financial conditions than LIBOs. Interestingly, this overheated LBO market condition in the post-2000 period does not greatly affect the deal characteristics of LIBOs, except that LIBOs were structured in significantly larger deal size. 


\section{Chapter 5: Results: Premiums Paid to Shareholders of LIBOs and LMBOs and the Explanatory Factors}

This chapter presents the results for the explanatory factors of the premiums paid to shareholders of LIBOs and LMBOs over the period 1985-2005. Different sets of explanatory variables of LMBO premiums are expected to be found over the three different sub periods (1985-1989, 1990-1999, and 2000-2005), since deal characteristics of LMBOs (including LMBO premiums) are found to have greatly changed over time (See results in Chapter 4). This study also expects to identify the interaction effects of LBO type dummy variable with the firm-specific variables, especially over the sub period 2000-2005, as LMBOs are found to have different deal characteristics (including premiums) than LIBOs at this sub period (See results in Chapter 4).

Subsequently, correlations among the independent firm-specific variables are examined in Section 5.1. Afterwards, the identified explanatory factors of the premiums in LIBOs and LMBOs over the three sub periods (1985-1989, 1990-1999, and 2000-2005) are described in Section 5.2.

\subsection{Correlation Examination}

Panel A of Table 5.1 presents a matrix of Pearson correlations controlled by year among the independent firm-specific variables as well as their correlations with LBO type dummy variable. Since LIBOs and LMBOs are two different types of LBOs, Pearson partial correlations (controlled by year) are performed separately for LIBOs and LMBOs (Results are presented in Panel B and C of Table 5.1). 
Table 5.1 Pearson Correlation Analysis

Year is controlled in the following partial correlation analyses.

"Multiplier (Transaction Value/EBITDA)", "Deal Size", “Assumed Liability / Transaction Value", “Volatility of Cash Flow", "Relative P/E", "Premiums 1 Week prior to LBO Announcement", "Investment Opportunities (Tobin's Q)", "LBO Type Dummy", "Scaled Undistributed Free Cash Flow", "Scaled Tax Expenditures", "3 Year Average Dividend Payout Ratio", "Managerial Ownership", "Net Sales", "Premiums 1 Day prior to LBO Announcement", "Premiums 4 Weeks prior to LBO Announcement", and "Challenged Deal Dummy" are included in the following analyses.

Panel A: Pearson Correlations among the Independent Firm-specific Variables for LBOs For LBO type dummy variable, "1" represents LMBOs and "-1" represents LIBOs.

\begin{tabular}{|c|c|c|c|c|c|c|c|c|c|c|c|c|c|c|c|c|}
\hline & 1) & 2) & 3) & 4) & 5) & 6) & 7) & $8)$ & 9) & 10) & 11) & 12) & 13) & 14) & 15) & 16) \\
\hline $\begin{array}{l}\text { 1) Multiplier } \\
\text { (Transaction } \\
\text { Value/EBITDA) }\end{array}$ & 1.00 & & & & & & & & & & & & & & & \\
\hline 2) Deal Size & 0.08 & 1.00 & & & & & & & & & & & & & & \\
\hline $\begin{array}{l}\text { 3) Assumed } \\
\text { Liability / } \\
\text { Transaction } \\
\text { Value } \\
\end{array}$ & 0.08 & $0.12^{-}$ & 1.00 & & & & & & & & & & & & & \\
\hline $\begin{array}{l}\text { 4) Volatility of } \\
\text { Free Cash }\end{array}$ & 0.17 & 0.11 & 0.09 & 1.00 & & & & & & & & & & & & \\
\hline 5) Relative P/E & 0.02 & 0.06 & 0.02 & 0.04 & 1.00 & & & & & & & & & & & \\
\hline $\begin{array}{l}\text { 6) Premiums } 1 \\
\text { Week prior to } \\
\text { LBO } \\
\text { Announcement }\end{array}$ & 0.15 & $\begin{array}{r}0.30 \\
* * * \\
\end{array}$ & 0.02 & 0.01 & 0.11 & 1.00 & & & & & & & & & & \\
\hline $\begin{array}{l}\text { 7) Investment } \\
\text { Opportunities } \\
\text { (Tobin's Q) } \\
\end{array}$ & $\begin{array}{r}0.25 \\
* * \\
\end{array}$ & $\begin{array}{r}0.28 \\
* * * \\
\end{array}$ & $\begin{array}{r}0.21 \\
* * \\
\end{array}$ & $0 . \overline{-}$ & $\begin{array}{r}0.18 \\
* \\
\end{array}$ & $\begin{array}{r}0.26 \\
* * * \\
\end{array}$ & 1.00 & & & & & & & & & \\
\hline $\begin{array}{l}\text { 8) LBO Type } \\
\text { Dummy }\end{array}$ & 0.15 & $\begin{array}{r}0.33 \\
* * * \\
\end{array}$ & 0.00 & $\begin{array}{r}0.28 \\
* * * \\
\end{array}$ & 0.07 & $\begin{array}{r}0.22 \\
* * \\
\end{array}$ & $\begin{array}{r}- \\
0.34 \\
* * *\end{array}$ & 1.00 & & & & & & & & \\
\hline $\begin{array}{l}\text { 9) Scaled } \\
\text { Undistributed } \\
\text { Free Cash Flow }\end{array}$ & 0.03 & 0.07 & $\begin{array}{r}0 \\
0.19 \\
*\end{array}$ & 0.01 & 0.09 & 0.08 & 0.06 & 0.03 & 1.00 & & & & & & & \\
\hline $\begin{array}{l}\text { 10) Scaled Tax } \\
\text { Expenditures }\end{array}$ & 0.05 & $\begin{array}{r}0.19 \\
* * \\
\end{array}$ & 0.11 & 0.07 & 0.02 & 0.10 & 0.12 & 0.09 & $\begin{array}{r}0.23 \\
* * \\
\end{array}$ & 1.00 & & & & & & \\
\hline $\begin{array}{l}\text { 11) } 3 \text { Year } \\
\text { Average } \\
\text { Dividend Payout } \\
\text { Ratio }\end{array}$ & 0.06 & 0.05 & 0.02 & 0.07 & 0.00 & 0.05 & 0.16 & $\begin{array}{r}- \\
0.18 \\
*\end{array}$ & 0.02 & 0.13 & 1.00 & & & & & \\
\hline $\begin{array}{l}\text { 12) Managerial } \\
\text { Ownership }\end{array}$ & 0.06 & $\begin{array}{r}0.33 \\
* * * \\
\end{array}$ & 0.04 & 0.13 & 0.14 & 0.13 & 0.10 & $\begin{array}{r}0.44 \\
* * * \\
\end{array}$ & 0.06 & 0.11 & $\begin{array}{r}0.20 \\
* \\
\end{array}$ & 1.00 & & & & \\
\hline 13) Net Sales & 0.01 & $\begin{array}{c}0.43 \\
* * *\end{array}$ & 0.12 & $\begin{array}{r}- \\
0.20 \\
*\end{array}$ & 0.03 & $\begin{array}{r}- \\
0.25 \\
* *\end{array}$ & $\begin{array}{r}0.29 \\
* * *\end{array}$ & $\begin{array}{r}0.23 \\
* *\end{array}$ & 0.02 & 0.01 & 0.05 & $\begin{array}{r}- \\
0.29 \\
* * *\end{array}$ & 1.00 & & & \\
\hline $\begin{array}{l}\text { 14) Premiums } 1 \\
\text { Day prior to LBO } \\
\text { Announcement }\end{array}$ & 0.15 & $\begin{array}{r}- \\
0.35 \\
* * *\end{array}$ & 0.05 & $\begin{array}{r}0.22 \\
* * \\
\end{array}$ & 0.09 & $\begin{array}{r}0.92 \\
* * * \\
\end{array}$ & $\begin{array}{r}0.26 \\
* * * \\
\end{array}$ & $\begin{array}{r}0.20 \\
*\end{array}$ & 0.01 & $\begin{array}{r}- \\
0.21 \\
* *\end{array}$ & 0.07 & $\begin{array}{r}0.19 \\
* \\
\end{array}$ & $\begin{array}{r}0.22 \\
* *\end{array}$ & 1.00 & & \\
\hline $\begin{array}{l}\text { 15) Premiums } 4 \\
\text { Weeks prior to } \\
\text { LBO } \\
\text { Announcement }\end{array}$ & 0.06 & $\begin{array}{r}- \\
0.30 \\
* * * \\
\end{array}$ & 0.07 & 0.17 & 0.09 & $\begin{array}{r}0.68 \\
* * * \\
\end{array}$ & $0.12^{-}$ & 0.09 & 0.04 & 0.14 & 0.00 & 0.11 & $\begin{array}{r}- \\
0.18 \\
*\end{array}$ & $\begin{array}{r}0.71 \\
* * * \\
\end{array}$ & 1.00 & \\
\hline $\begin{array}{l}\text { 16) Challenged } \\
\text { Deal Dummy }\end{array}$ & 0.03 & 0.04 & 0.04 & 0.05 & 0.11 & $\begin{array}{r}- \\
0.18 \\
\end{array}$ & 0.09 & 0.07 & 0.03 & $\begin{array}{r}0.24 \\
* * \\
\end{array}$ & 0.01 & 0.12 & 0.11 & $\begin{array}{r}- \\
0.17\end{array}$ & $\begin{array}{r}- \\
0.14\end{array}$ & 1.00 \\
\hline
\end{tabular}
Note $(1): *, * *$, and $* * *$ indicates statistical significance at $10 \%, 5 \%$, and $1 \%$ levels respectively.

(2): This study obtains similar findings performing correlation analysis 
Panel B: Pearson Correlations among the Independent Firm-specific Variables for LIBOs

\begin{tabular}{|c|c|c|c|c|c|c|c|c|c|c|c|c|c|c|c|}
\hline & 1) & 2) & 3) & 4) & 5) & 6) & 7) & 9) & $10)$ & 11) & 12) & 13) & 14) & 15) & 16) \\
\hline $\begin{array}{l}\text { 1) Multiplier } \\
\text { (Transaction } \\
\text { Value/EBITDA) }\end{array}$ & 1.00 & & & & & & & & & & & & & & \\
\hline 2) Deal Size & 0.03 & 1.00 & & & & & & & & & & & & & \\
\hline $\begin{array}{l}\text { 3) Assumed } \\
\text { Liability / } \\
\text { Transaction Value }\end{array}$ & - & - & 1.00 & & & & & & & & & & & & \\
\hline $\begin{array}{l}\text { 4) Volatility of Free } \\
\text { Cash }\end{array}$ & 0.11 & 0.05 & 0.00 & 1.00 & & & & & & & & & & & \\
\hline 5) Relative P/E & 0.11 & 0.03 & $\overline{0}-16$ & 0.05 & 1.00 & & & & & & & & & & \\
\hline $\begin{array}{l}\text { 6) Premiums } 1 \\
\text { Week prior to LBO } \\
\text { Announcement }\end{array}$ & 0.12 & 0.19 & 0.13 & 0.07 & 0.07 & 1.00 & & & & & & & & & \\
\hline $\begin{array}{l}\text { 7) Investment } \\
\text { Opportunities } \\
\text { (Tobin's Q) }\end{array}$ & $\begin{array}{l}0.27 \\
* \\
\end{array}$ & 0.17 & $\begin{array}{l}- \\
0.32 \\
* *\end{array}$ & 0.00 & $\begin{array}{l}0.32 \\
* * \\
\end{array}$ & $\begin{array}{l}- \\
0.22 \\
\end{array}$ & 1.00 & & & & & & & & \\
\hline $\begin{array}{l}\text { 9) Scaled } \\
\text { Undistributed Free } \\
\text { Cash Flow }\end{array}$ & 0.15 & 0.01 & $\begin{array}{l}- \\
0.51 \\
* * *\end{array}$ & 0.02 & $\begin{array}{l}0.39 \\
* * \\
\end{array}$ & 0.23 & 0.16 & 1.00 & & & & & & & \\
\hline $\begin{array}{l}\text { 10) Scaled Tax } \\
\text { Expenditures }\end{array}$ & 0.15 & 0.17 & $\begin{array}{l}- \\
0.28 \\
*\end{array}$ & 0.04 & 0.10 & 0.02 & 0.06 & $\begin{array}{l}0.23 \\
* * \\
\end{array}$ & 1.00 & & & & & & \\
\hline $\begin{array}{l}\text { 11) } 3 \text { Year Average } \\
\text { Dividend Payout } \\
\text { Ratio }\end{array}$ & 0.09 & 0.08 & $\overline{0} 00$ & $\overline{0.15}$ & $\overline{0.06}$ & $\overline{0.09}$ & 0.03 & $\overline{0.02}$ & 0.02 & 1.00 & & & & & \\
\hline $\begin{array}{l}\text { 12) Managerial } \\
\text { Ownership }\end{array}$ & 0.12 & $\begin{array}{l} \\
0.34 \\
* *\end{array}$ & $\overline{-} .03$ & 0.23 & 0.07 & 0.17 & $\overline{0.08}$ & 0.06 & 0.16 & $\begin{array}{l} \\
0.24 \\
*\end{array}$ & 1.00 & & & & \\
\hline 13) Net Sales & $\begin{array}{l}- \\
0.10\end{array}$ & 0.25 & $\overline{0.08}$ & $\begin{array}{l}- \\
0.17\end{array}$ & $\overline{0.09}$ & 0.20 & 0.22 & $\overline{0.02}$ & $\overline{0.09}$ & 0.05 & $\begin{array}{l} \\
0.24\end{array}$ & 1.00 & & & \\
\hline $\begin{array}{l}\text { 14) Premiums } 1 \\
\text { Day prior to LBO } \\
\text { Announcement }\end{array}$ & 0.11 & $\begin{array}{l}- \\
0.36 \\
* * *\end{array}$ & 0.00 & 0.13 & 0.09 & $\begin{array}{l}0.83 \\
* * *\end{array}$ & $\begin{array}{l}- \\
0.27 \\
*\end{array}$ & 0.01 & 0.09 & 0.07 & $\begin{array}{l}0.37 \\
* * \\
\end{array}$ & $\overline{0} .18$ & 1.00 & & \\
\hline $\begin{array}{l}\text { 15) Premiums } 4 \\
\text { Weeks prior to } \\
\text { LBO } \\
\text { Announcement }\end{array}$ & $\overline{0.02}$ & - & 0.05 & 0.12 & 0.08 & $\begin{array}{l}0.62 \\
* * *\end{array}$ & 0.15 & 0.04 & - & 0.00 & $\begin{array}{l}0.30 \\
*\end{array}$ & - & $\begin{array}{l}0.77 \\
* * *\end{array}$ & 1.00 & \\
\hline $\begin{array}{l}\text { 16) Challenged } \\
\text { Deal Dummy }\end{array}$ & 0.05 & 0.02 & 0.00 & 0.07 & 0.03 & $\overline{0} .16$ & 0.04 & 0.03 & $\begin{array}{l}0.31 \\
* \\
\end{array}$ & 0.01 & $\overline{0}-10$ & 0.23 & 0.10 & 0.12 & 1.00 \\
\hline
\end{tabular}

Note (1): *,**, and *** indicates statistical significance at $10 \%, 5 \%$, and $1 \%$ levels respectively.

(2): This study obtains similar findings performing correlation analysis. 
Panel C: Pearson Correlations among the Independent Firm-specific Variables for LMBOs

\begin{tabular}{|c|c|c|c|c|c|c|c|c|c|c|c|c|c|c|c|}
\hline & 1) & 2) & 3) & 4) & 5) & 6) & 7) & 9) & 10) & 11) & 12) & 13) & 14) & 15) & 16) \\
\hline $\begin{array}{l}\text { 1) Multiplier } \\
\text { (Transaction } \\
\text { Value/EBITDA) }\end{array}$ & 1.00 & & & & & & & & & & & & & & \\
\hline 2) Deal Size & 0.07 & 1.00 & & & & & & & & & & & & & \\
\hline $\begin{array}{l}\text { 3) Assumed } \\
\text { Liability / } \\
\text { Transaction Value }\end{array}$ & 0.01 & 0.14 & 1.00 & & & & & & & & & & & & \\
\hline $\begin{array}{l}\text { 4) Volatility of } \\
\text { Free Cash }\end{array}$ & 0.19 & 0.03 & 0.12 & 1.00 & & & & & & & & & & & \\
\hline 5) Relative $P / E$ & 0.14 & 0.10 & 0.12 & 0.05 & 1.00 & & & & & & & & & & \\
\hline $\begin{array}{l}\text { 6) Premiums } 1 \\
\text { Week prior to } \\
\text { LBO } \\
\text { Announcement }\end{array}$ & 0.08 & $\begin{array}{r}0.31 \\
* * \\
\end{array}$ & 0.01 & 0.17 & 0.21 & 1.00 & & & & & & & & & \\
\hline $\begin{array}{l}\text { 7) Investment } \\
\text { Opportunities } \\
\text { (Tobin's Q) }\end{array}$ & $\begin{array}{r}0.29 \\
* *\end{array}$ & $\begin{array}{r}0.33 \\
* *\end{array}$ & 0.13 & 0.17 & $0.18^{-}$ & $\begin{array}{r}0.39 \\
* * *\end{array}$ & 1.00 & & & & & & & & \\
\hline $\begin{array}{l}\text { 9) Scaled } \\
\text { Undistributed Free } \\
\text { Cash Flow }\end{array}$ & $0.10^{-}$ & 0.17 & 0.04 & 0.02 & 0.01 & 0.03 & $0.01^{-}$ & 1.00 & & & & & & & \\
\hline $\begin{array}{l}\text { 10) Scaled Tax } \\
\text { Expenditures }\end{array}$ & 0.09 & 0.10 & 0.17 & $0.12^{-}$ & $\begin{array}{r}- \\
0.18 \\
\end{array}$ & $\begin{array}{r}0.34 \\
* * \\
\end{array}$ & $\begin{array}{r}0.32 \\
* * \\
\end{array}$ & $0.2 \overline{1}$ & 1.00 & & & & & & \\
\hline $\begin{array}{l}\text { 11) } 3 \text { Year } \\
\text { Average Dividend } \\
\text { Payout Ratio }\end{array}$ & 0.07 & $\begin{array}{r}0.31 \\
* * \\
\end{array}$ & 0.11 & 0.18 & $\begin{array}{r}- \\
0.10 \\
\end{array}$ & $\begin{array}{r}-\overline{-} \\
0.26 \\
*\end{array}$ & $\begin{array}{r}0.28 \\
* \\
\end{array}$ & 0.19 & 0.12 & 1.00 & & & & & \\
\hline $\begin{array}{l}\text { 12) Managerial } \\
\text { Ownership }\end{array}$ & 0.18 & $\begin{array}{r}0.08 \\
* *\end{array}$ & $0.4 \overline{9}$ & $0.0 \overline{8}$ & 0.06 & 0.03 & $\begin{array}{r}0.44 \\
* *\end{array}$ & 0.06 & $\begin{array}{r}0.36 \\
* *\end{array}$ & $0.22^{-}$ & 1.00 & & & & \\
\hline 13) Net Sales & 0.03 & $\begin{array}{r}0.69 \\
* * *\end{array}$ & 0.18 & 0.15 & 0.00 & $\begin{array}{r}0.24 \\
* \\
\end{array}$ & $\begin{array}{r}0.31 \\
* *\end{array}$ & 0.02 & 0.11 & $\begin{array}{r}0.56 \\
* * *\end{array}$ & 0.20 & 1.00 & & & \\
\hline $\begin{array}{l}\text { 14) Premiums } 1 \\
\text { Day prior to LBO } \\
\text { Announcement }\end{array}$ & 0.09 & $\begin{array}{r}- \\
0.27 \\
*\end{array}$ & 0.03 & 0.17 & 0.18 & $\begin{array}{l}0.95 \\
* * * \\
\end{array}$ & $\begin{array}{r}0.36 \\
* *\end{array}$ & 0.04 & $\begin{array}{r}0.31 \\
* * \\
\end{array}$ & $\begin{array}{r}- \\
0.25 \\
* \\
\end{array}$ & 0.00 & 0.21 & 1.00 & & \\
\hline $\begin{array}{l}\text { 15) Premiums } 4 \\
\text { Weeks prior to } \\
\text { LBO } \\
\text { Announcement }\end{array}$ & 0.01 & $\begin{array}{r}- \\
0.31 \\
* *\end{array}$ & 0.06 & 0.16 & 0.20 & $\begin{array}{c}0.70 \\
* * * \\
\end{array}$ & 0.13 & 0.05 & $\begin{array}{r}- \\
0.28 \\
* \\
\end{array}$ & $0.20^{-}$ & 0.06 & 0.21 & $\begin{array}{c}0.67 \\
* * *\end{array}$ & 1.00 & \\
\hline $\begin{array}{l}\text { 16) Challenged } \\
\text { Deal Dummy }\end{array}$ & 0.02 & 0.00 & 0.04 & 0.03 & 0.01 & 0.04 & 0.11 & 0.14 & $\begin{array}{r}- \\
0.06 \\
\end{array}$ & $\begin{array}{r}0.34 \\
* * \\
\end{array}$ & 0.21 & 0.03 & $\begin{array}{r}- \\
0.05 \\
\end{array}$ & 0.06 & 1.00 \\
\hline
\end{tabular}

Note (1): *,*, and *** indicates statistical significance at $10 \%, 5 \%$, and $1 \%$ levels respectively.

(2): This study obtains similar findings performing correlation analysis 
Based on Table 5.1, there are the following major findings for the partial correlations among the variables examined by this study:

1) There are significant and positive correlations found among premiums 1 week prior to LBO announcement, premiums 1 day prior to LBO announcement, and premiums 4 weeks prior to LBO announcement (See Panel A, B and C of Table 5.1 for the corresponding results). Thus, this study only reports the results of the OLS regressions with premiums 1 week prior to LBO announcement as the dependent variable.

2) There are significant correlations between Tobin's Q and the other firm-specific variables such as deal size, net sales, relative $\mathrm{P} / \mathrm{E}$, assumed debt/transaction value, and volatility of cash flow. Thus, the effects of Tobin's Q on LBO premiums can be subjected to different interpretations, and the potential multicollinearity needs to be carefully controlled in the following analyses.

3) The central variable of the free cash flow hypothesis, undistributed free cash flow scaled by firm's net sales, is not correlated to most of the other variables including dividend payout ratio, volatility of free cash flow, and investment opportunities. This excludes the possibility that the subsequent results for the free cash flow hypothesis are clouded by multicollinearity among the independent variables.

4) Panel A of Table 5.1 shows that managerial ownership is significantly positively related to LBO type dummy variable. ${ }^{44}$ This finding is consistent with Halpern et al (1999)'s heterogeneity hypothesis that firms with lower managerial ownership

\footnotetext{
${ }^{44}$ For LBO type dummy variable, "1" represents LMBOs and "-1" represents LIBOs.
} 
usually go private via LIBOs, while firms with higher managerial ownership tend to go private via LMBOs.

\subsection{OLS Regression on LBO Premiums over Three Sub periods}

This section describes the results of OLS regressions for the explanatory factors of LBO premiums over the three sub periods. As expected, this study finds different sets of explanatory variables of LBO premiums over the three sub periods. In the following, the

results for explanatory factors of LBO premiums over each sub period are presented followed by a description of the results and a discussion of their implications. 
Table 5.2: OLS Regression on LBO Premiums over the Sub Period 1985-1989

"Premiums 1 Week prior to LBO Announcement", "Investment Opportunities (Tobin's Q)" "Scaled Undistributed Free Cash Flow", "Challenged Deal Dummy", and "Scaled Tax Expenditures" are included in the following analyses.

Outliers are detected using Weisberg t-test statistic. Some outliers are deleted after careful assessments as there are some values that seem documented wrongly in the database or are too high or low to make any financial sense.

The results reported subsequently are obtained using "(EBITDA-Tax-Interests-Dividends)/Net Sales" as the proxy for the pre-buyout level of free cash flow and using "Premiums I Week prior to LBO Announcement" as the proxy for the LBO premiums.

\begin{tabular}{|c|c|c|c|c|c|}
\hline & & Model 1 & Model 2 & Model 3 & Model 4 \\
\hline \multirow[t]{3}{*}{ (Constant) } & Beta & 63.20 & 61.50 & 41.24 & 63.42 \\
\hline & t-stat & 7.96 & 9.50 & 15.34 & 9.45 \\
\hline & Sig. & $0.00 * * *$ & $0.00 * * *$ & $0.00 * * *$ & $0.00 * * *$ \\
\hline Investment Opportunities & Beta & -10.87 & -10.37 & & -12.36 \\
\hline \multirow{2}{*}{ (Tobin's Q) } & t-stat & -3.03 & -2.79 & & -3.48 \\
\hline & Sig. & $0.00^{* * *}$ & $0.01 * * *$ & & $0.00^{* * *}$ \\
\hline \multirow[t]{3}{*}{ Scaled Tax Expenditures } & Beta & & -60.74 & & \\
\hline & $\mathrm{t}$-stat & & -0.54 & & \\
\hline & Sig. & & 0.59 & & \\
\hline Scaled Undistributed & Beta & 23.19 & & & \\
\hline \multirow[t]{2}{*}{ Free Cash Flow } & t-stat & 0.64 & & & \\
\hline & Sig. & 0.53 & & & \\
\hline (Scaled Undistributed & Beta & & & 51.61 & 49.77 \\
\hline \multirow[t]{2}{*}{ Free Cash Flow) ${ }^{2}$} & t-stat & & & 4.89 & 4.86 \\
\hline & Sig. & & & $0.00 * * *$ & $0.00 * * *$ \\
\hline R Square & & 0.14 & 0.13 & 0.23 & 0.35 \\
\hline Adjusted R Square & & 0.10 & 0.11 & 0.22 & 0.33 \\
\hline F & & 3.77 & 5.38 & 23.94 & 18.69 \\
\hline Sig. & & $0.01 * * *$ & $0.01 * * *$ & $0.00 * * *$ & $0.00 * * *$ \\
\hline $\mathbf{N}$ & & 73 & 73 & 73 & 73 \\
\hline
\end{tabular}

Note (1): *,**, and *** indicates statistical significance at 10\%, 5\%, and $1 \%$ levels respectively.

(2): This study obtains similar results using an alternate measure of pre-buyout level of free cash flow (Cash Flow from Operations-Capital Expenditure-Net changes in working capital)/Net Sales.

(3): Challenged deal dummy variable is not found significant.

As shown in Table 5.2, this study does not find a significant coefficient on the undistributed free cash flow variable over the sub period 1985-1989. This finding is consistent with the previously conducted research by Halpern et al (1999), Kieschnick (1998), and Opler and Titman (1993).

This study unexpectedly finds a significantly positive relation between square of the scaled undistributed free cash flow variable and LMBO premiums and R Square of the 
model has been greatly improved. ${ }^{45}$ This interesting finding implies that LMBO populations were heterogeneous over the sub period $1985-1989 .{ }^{46}$ Specifically, there were actually two groups of firms that went private via LMBOs in the late 1980s: LMBOs with higher levels of undistributed free cash flows and LMBOs with lower levels of undistributed free cash flows. Interestingly, the effects of undistributed free cash flows on LBO premiums were opposite for these two groups: For LMBOs with higher levels of undistributed free cash flows, the more free cash flows they had, the higher premiums were paid for them; On the contrary, for LMBOs with lower levels of undistributed free cash flows, the less free cash flows they had, the higher premiums were paid for them. One possible explanation for this finding is that LMBO premiums in the late 1980 s were not paid for the sufficiency of pre-buyout free cash flows (and thus not for the potentials for agency cost reductions after buyout either) due to the overheated market conditions. Moreover, the impacts of the overheated market conditions are more obvious for the worse-performing LMBO targets (firms with lower levels of pre-buyout free cash flows).

\footnotetext{
${ }^{45}$ Square of the scaled undistributed free cash flow variable is not listed in the research hypotheses of this study, as it is rarely examined in the previous research and there is no strong theoretical background for it.

${ }^{46}$ As a robustness check, this study divides the LMBO sample over the sub period 1985-1989 into two sub samples by scaled undistributed free cash flow: poorly performing LMBOs (proxied by negative scaled free cash flow) and well performing LMBOs (proxied by positive scaled free cash flow). This study finds a significantly negative relation between the LBO premiums and the scaled free cash flow variable for the poorly performing LMBOs, while the positive coefficient on the scaled free cash flow variable for well performing LMBOs is still insignificant.
} 
Table 5.3: OLS Regression on LBO Premiums over the Sub Period 1990-1999

"Volatility of Cash Flow", "Relative P/E", "Premiums 1 Week prior to LBO Announcement", "Investment Opportunities (Tobin's Q)", "Firm-specific Variables *LBO Type Dummy", "Scaled Undistributed Free Cash Flow", "Scaled Tax Expenditures", "3 Year Average Dividend Payout Ratio", "Challenged Deal Dummy", and "Managerial Ownership are included in the following analyses.

Dividend payout ratio and undistributed free cash flow are not highly correlated, thus both variables can be included in the same OLS regression models.

Outliers are detected using Weisberg t-test statistic. Some outliers are deleted after careful assessments as there are some values that seem documented wrongly in the database or are too high or low to make any financial sense.

The results reported subsequently are obtained using "(EBITDA-Tax-Interests-Dividends)/Net Sales" as the proxy for the pre-buyout level of free cash flow and using "Premiums 1 Week prior to LBO Announcement" as the proxy for the LBO premiums.

\begin{tabular}{|c|c|c|c|c|c|c|}
\hline & & Model 1 & Model 2 & Model 3 & Model 4 & Model 5 \\
\hline \multirow[t]{3}{*}{ (Constant) } & Beta & 30.68 & 31.11 & 25.59 & 25.04 & 28.89 \\
\hline & t-stat & 7.32 & 6.91 & 4.37 & 4.29 & 5.95 \\
\hline & Sig. & $0.00 * * *$ & $0.00 * * *$ & $0.00 * * *$ & $0.00 * * *$ & $0.00 * * *$ \\
\hline Investment & Beta & -4.19 & -4.17 & -2.75 & -2.94 & -3.22 \\
\hline Opportunities (Tobin's & t-stat & -2.70 & -2.69 & -1.81 & -1.93 & -2.11 \\
\hline Q) & Sig. & $0.01 * * *$ & $0.01 * * *$ & $0.08 * *$ & $0.06^{* *}$ & $0.04^{* *}$ \\
\hline Scaled Tax & Beta & & -24.17 & & & -190.31 \\
\hline \multirow[t]{2}{*}{ Expenditures } & t-stat & & -0.27 & & & -1.61 \\
\hline & Sig. & & 0.79 & & & 0.12 \\
\hline Scaled Undistributed & Beta & 61.93 & 62.07 & 82.14 & 84.30 & 82.56 \\
\hline \multirow[t]{2}{*}{ Free Cash Flow } & t-stat & 3.12 & 3.33 & 4.36 & 4.47 & 4.06 \\
\hline & Sig. & $0.00 * * *$ & $0.00 * * *$ & $0.00 * * *$ & $0.00 * * *$ & $0.00 * * *$ \\
\hline \multirow[t]{3}{*}{ Relative P/E } & Beta & & & & & -0.05 \\
\hline & t-stat & & & & & -0.65 \\
\hline & Sig. & & & & & 0.52 \\
\hline Volatility of Cash & Beta & & & & & -0.02 \\
\hline \multirow[t]{2}{*}{ Flow } & t-stat & & & & & -0.26 \\
\hline & Sig. & & & & & 0.40 \\
\hline 3 Year Average & Beta & 0.35 & 0.36 & 0.41 & 0.42 & \\
\hline \multirow[t]{2}{*}{ Dividend Payout Ratio } & t-stat & 2.50 & 2.65 & 3.07 & 3.15 & \\
\hline & Sig. & $0.01 * * *$ & $0.01 * * *$ & $0.00 * * *$ & $0.00 * * *$ & \\
\hline Scaled Free Cash & Beta & -2.17 & & & & \\
\hline Flow* LBO Type & t-stat & -0.12 & & & & \\
\hline Dummy & Sig. & 0.90 & & & & \\
\hline \multirow[t]{3}{*}{ Managerial Ownership } & & & & -0.06 & -0.03 & \\
\hline & & & & -0.53 & -0.26 & \\
\hline & & & & 0.60 & 0.80 & \\
\hline Managerial & & & & & -0.09 & \\
\hline Ownership* LBO & & & & & -1.16 & \\
\hline Type Dummy & & & & & 0.25 & \\
\hline R Square & & 0.23 & 0.23 & 0.38 & 0.41 & 0.37 \\
\hline Adjusted R Square & & 0.18 & 0.18 & 0.32 & 0.32 & 0.30 \\
\hline $\mathrm{F}$ & & 4.65 & 4.67 & 5.72 & 4.89 & 5.45 \\
\hline Sig. & & $0.00 * * *$ & $0.00 * * *$ & $0.00^{* * *}$ & $0.00 * * *$ & $0.00^{* * *}$ \\
\hline $\mathrm{N}$ & & 68 & 68 & 42 & 42 & 43 \\
\hline
\end{tabular}

Note (1): *,**, and $* * *$ indicates statistical significance at $10 \%, 5 \%$, and $1 \%$ levels respectively.

(2): This study obtains similar results using an alternate measure of pre-buyout level of free cash flow (Cash Flow from Operations-Capital Expenditure-Net changes in working capital)/Net Sales.

(3): None of the interaction terms (including interaction of volatility of cash flow, interaction of dividend payout ratio, interaction of investment opportunities, interaction of challenged deals, interaction of relative $P / E$, and interaction of tax expenditures) is found significant.

(4): Challenged deal dummy variable is not found significant. 
Over the sub period 1990-1999, this study does not find significance of any interactions between firm-specific variables and LBO type dummy variable. It implies that there are no significant differences between LIBOs and LMBOs in explanatory factors of LBO premiums in the 1990s. This is consistent with the result of MANOVA (documented in Chapter 4) that there are no significant differences in the deal characteristics between LIBOs and LMBOs in the 1990s.

The other findings on factors explaining the LBO premiums in the 1990s support the free cash flow hypothesis. First, the undistributed free cash flow variable is found positively related to LBO premiums for both LIBOs and LMBOs in the 1990 s. ${ }^{47}$ Second, the investment opportunities are found to have a significant and negative relation with LBO premiums in the 1990s. Third, consistent with Maupin et al (1984), this study finds a significantly positive relation between dividend payout ratio and LBO premiums. ${ }^{48}$ This finding suggests that higher premiums are paid for LBOs with higher divided payout ratios. It implies that candidates for LBOs in the 1990s are still mature, slow-growth companies that usually have relative high dividend payout ratios.

As a robustness check, this study further performs two separate OLS regressions on LBO premiums for LIBOs and LMBOs over the sub period 1990-1999 (Results are presented in Table 5.4). The results for investment opportunity and undistributed free cash flow are consistent with those of pooled OLS regressions for LBOs in the 1990s (Results are

\footnotetext{
${ }^{47}$ This result is consistent with the finding of Lehn and Poulsen (1989). However, compared to their research, this study uses the improved proxies for the undistributed free cash flow variable. Moreover, the results of this study are based on LIBOs and LMBOs in the 1990s, rather than in the 1980s.

${ }^{48}$ Note that this result is not affected by multicollinearity issue, as divided payout ratio is not found correlated with the other independent variables such as Tobin's $Q$ (proxying for investment opportunities) or undistributed free cash flow.
} 
presented in Table 5.3): For both LIBOs and LMBOs, higher premiums were paid for

firms with less investment opportunities and higher undistributed pre-buyout level of free

cash flow in the 1990 s.

Table 5.4: Separate OLS Regression on LBO Premiums for LIBOs and LMBOs over the Sub Period 1990-1999

"Volatility of Cash Flow", "Relative P/E", "Premiums 1 Week prior to LBO Announcement", "Investment Opportunities (Tobin's Q)", "Scaled Undistributed Free Cash Flow", "3 Year Average Dividend Payout Ratio", and "Managerial Ownership are included in the following analyses.

Outliers are detected using Weisberg t-test statistic. Some outliers are deleted after careful assessments as there are some values that seem documented wrongly in the database or are too high or low to make any financial sense.

The results reported subsequently are obtained using "(EBITDA-Tax-Interests-Dividends)/Net Sales" as the proxy for the pre-buyout level of free cash flow and using "Premiums 1 Week prior to LBO Announcement" as the proxy for the LBO premiums.

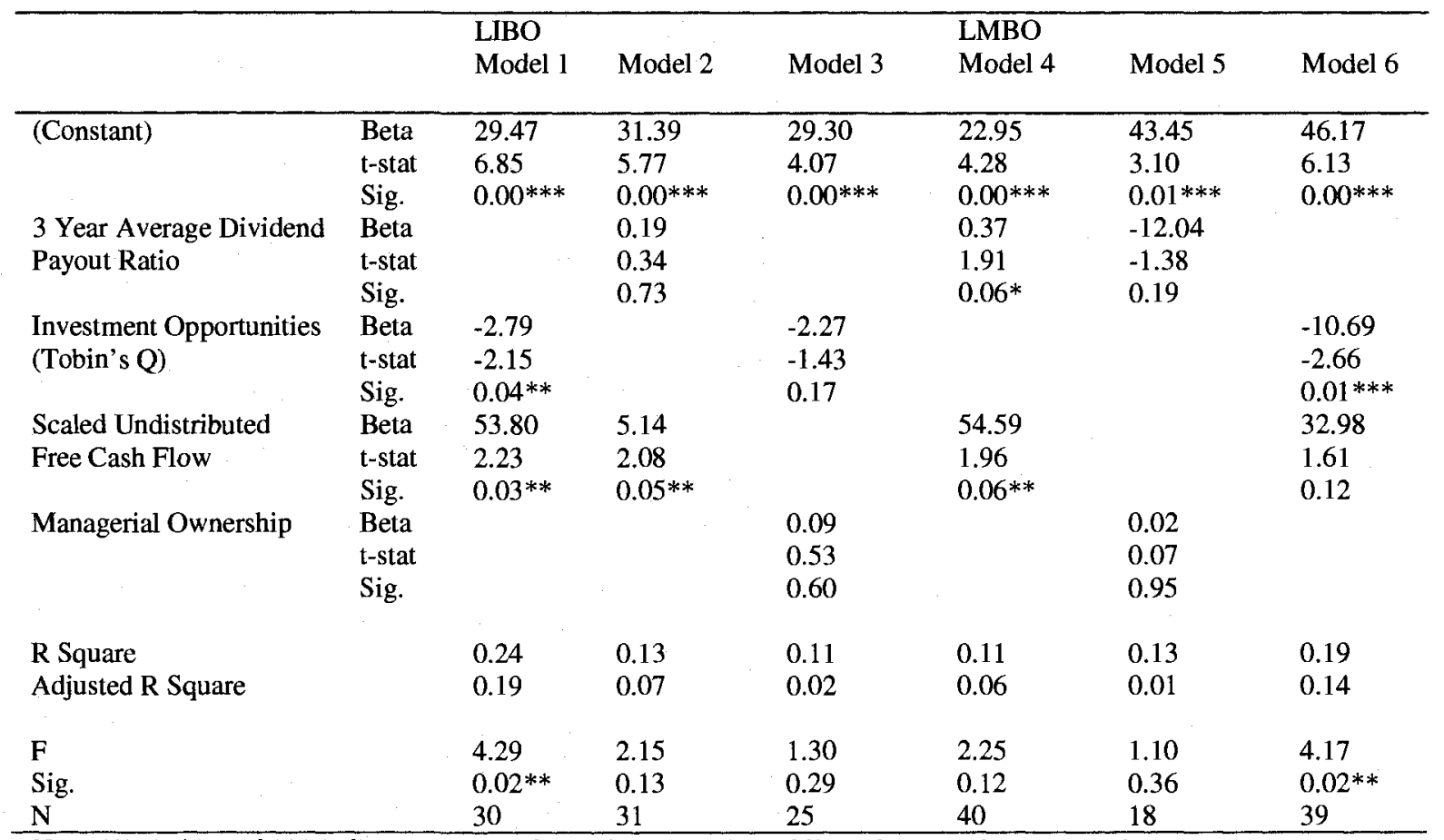

Note $(1): *, * *$, and $* * *$ indicates statistical significance at $10 \%, 5 \%$, and $1 \%$ levels respectively.

(2): This study obtains similar results using an alternate measure of pre-buyout level of free cash flow (Cash Flow from Operations-Capital Expenditure-Net changes in working capital)/Net Sales.

(3): Volatility of Cash Flow and Relative P/E are not found significant. 
Table 5.5: OLS Regression on LBO Premiums over the Sub Period 2000-2005

"Volatility of Cash Flow", "Relative P/E", "Premiums 1 Week prior to LBO Announcement", "Investment Opportunities (Tobin's Q)", "Firm-specific Variables *LBO Type Dummy", "Scaled Undistributed Free Cash Flow", "Scaled Tax Expenditures", "3 Year Average Dividend Payout Ratio", "Challenged Deal Dummy", and "Managerial Ownership are included in the following analyses. Outliers are detected using Weisberg t-test statistic. Some outliers are deleted after careful assessments as there are some values that seem documented wrongly in the database or are too high or low to make any financial sense. The results reported subsequently are obtained using "(EBITDA-TaxInterests-Dividends)/Net Sales" as the proxy for the pre-buyout level of free cash flow and using "Premiums 1 Week prior to LBO Announcement" as the proxy for the LBO premiums.

\begin{tabular}{|c|c|c|c|c|c|c|c|}
\hline & & Model 1 & Model 2 & Model 3 & Model 4 & Model 5 & Model 6 \\
\hline \multirow[t]{3}{*}{ (Constant) } & Beta & 56.01 & 57.71 & 51.37 & 45.02 & 51.90 & 59.31 \\
\hline & t-stat & 7.23 & 5.61 & 5.99 & 4.85 & 5.09 & 6.05 \\
\hline & Sig. & $0.00^{* * * *}$ & $0.00 * * *$ & $0.00^{* * *}$ & $0.00^{* * *}$ & $0.00 * * *$ & $0.00 * * *$ \\
\hline Investment & Beta & -16.24 & -17.49 & -13.04 & -10.13 & -21.03 & -22.69 \\
\hline Opportunities & t-stat & -3.84 & -4.47 & -3.16 & -2.62 & -4.40 & -3.98 \\
\hline (Tobin's Q) & Sig. & $0.00 * * *$ & $0.00 * * *$ & $0.00^{* * *}$ & $0.01 * * *$ & $0.00 * * *$ & $0.00 * * *$ \\
\hline Scaled Free Cash & Beta & -136.24 & -147.80 & & -133.97 & -102.26 & \\
\hline Flow* LBO Type & t-stat & -3.88 & -3.75 & & -3.19 & -2.61 & \\
\hline Dummy & Sig. & $0.00^{* * *}$ & $0.00^{* * *}$ & & $0.00^{* * *}$ & $0.01^{* * *}$ & \\
\hline Scaled Undistributed & Beta & -2.78 & & & & & \\
\hline \multirow[t]{2}{*}{ Free Cash Flow } & t-stat & -0.06 & & & & & \\
\hline & Sig. & 0.95 & & & & & \\
\hline Managerial & Beta & 0.51 & 0.43 & 0.39 & 0.18 & 0.45 & 0.41 \\
\hline \multirow[t]{2}{*}{ Ownership } & t-stat & 3.00 & 2.32 & 1.84 & 0.92 & 2.17 & 2.02 \\
\hline & Sig. & $0.00^{* * * *}$ & $0.02 * *$ & $0.07 * *$ & 0.36 & $0.03^{* *}$ & $0.05^{* *}$ \\
\hline \multirow[t]{3}{*}{ Relative P/E } & Beta & & & & & 0.44 & 0.59 \\
\hline & t-stat & & & & & 1.58 & 2.31 \\
\hline & Sig. & & & & & 0.12 & $0.02 * *$ \\
\hline Volatility of Cash & Beta & & & & 0.60 & 0.37 & \\
\hline \multirow[t]{2}{*}{ Flow } & t-stat & & & & 1.00 & 0.62 & \\
\hline & Sig. & & & & 0.32 & 0.54 & \\
\hline 3 Year Average & Beta & & & -0.23 & & & -0.17 \\
\hline Dividend Payout & t-stat & & & -1.04 & & & -0.73 \\
\hline Ratio & Sig. & & & 0.30 & & & 0.47 \\
\hline Assumed Liability / & Beta & & 11.82 & & 14.18 & & \\
\hline Transaction Value* & t-stat & & 2.05 & & 2.38 & & \\
\hline LBO Type Dummy & Sig. & & $0.04 * *$ & & $0.02 * *$ & & \\
\hline Assumed Liability / & Beta & & -8.24 & & & & \\
\hline \multirow[t]{2}{*}{ Transaction Value } & t-stat & & -0.98 & & & & \\
\hline & Sig. & & 0.33 & & & & \\
\hline Relative P/E* LBO & & & & & & & -0.35 \\
\hline \multirow[t]{2}{*}{ Type Dummy } & & & & & & & -1.37 \\
\hline & & & & & & & 0.18 \\
\hline Managerial & & & & 0.00 & & & \\
\hline Ownership* LBO & & & & 0.03 & & & \\
\hline Type Dummy & & & & 0.98 & & & \\
\hline R Square & & 0.38 & 0.35 & 0.22 & 0.26 & 0.35 & 0.31 \\
\hline Adjusted R Square & & 0.33 & 0.30 & 0.17 & 0.20 & 0.29 & 0.25 \\
\hline$F$ & & 7.81 & 6.98 & 4.59 & 4.30 & 5.40 & 5.01 \\
\hline Sig. & & $0.00 * * *$ & $0.00 * * *$ & $0.00^{* * * *}$ & $0.00^{* * * *}$ & $0.00^{* * * *}$ & $0.00 * * *$ \\
\hline $\mathrm{N}$ & & 71 & 70 & 70 & 66 & 56 & 61 \\
\hline
\end{tabular}

Note $(1): *, * *$, and $* * *$ indicates statistical significance at $10 \%, 5 \%$, and $1 \%$ levels respectively.

(2): This study obtains similar results using an alternate measure of pre-buyout level of free cash flow (Cash Flow from Operations-Capital Expenditure-Net changes in working capital)/Net Sales.

(3): This study does not find sales growth rate has a significant coefficient when it is included as independent variable, though it has a negative sign.

(4): Scaled tax expenditures and challenged deal dummy variables are not found significant. 
Over the sub period 2000-2005, the findings of this study are different from the results for factors explaining LBO premiums over the previous sub periods. The key findings over the sub period 2000-2005 are described as follows.

First, this study unexpectedly finds that the interaction between assumed liabilitytransaction value ratio and LBO type dummy variable is positively related to LBO premiums over the sub period $2000-2005 .{ }^{49}$ This suggests that higher premiums were paid for LMBOs with higher levels of assumed liability-transaction ratios and LIBOs with lower levels of assumed liability-transaction ratios. It further implies that LMBO premiums over the sub period 2000-2005 may be mainly pushed by debt financing, while institutions adjusted the premiums down when using more debt financing (which normally leads to higher financial bankruptcy costs).

Second, this study finds a significant and negative relation between LBO premiums and the interaction of undistributed free cash flow with LBO type dummy over the sub period 2000-2005. This result suggests that higher premiums were paid for LIBOs with higher pre-buyout levels of free cash flows and for LMBOs with lower pre-buyout levels of free cash flows.

Third, this study finds a negative, though insignificant, relation between dividend payout ratio and LBO premiums over the sub period 2000-2005. This finding is different from what is found over the sub period 1990-1999: There is a significant and positive relation

\footnotetext{
${ }^{49}$ Note that the variable assumed liability-transaction value ratio is not listed in the original research hypotheses of this study, as it is rarely examined in the previous research and there is no strong theoretical background for it.
} 
between dividend payout ratio and LBO premiums over the sub period 1990-1999. One plausible explanation for this negative relation is that LBO market may have moved to high-growth, technology-driven industries, so that higher premiums are paid for target firms with higher growth rate, thus lower dividend payout ratio (Allen, 1996). To further explore this possibility, this study includes 5-year sales growth rate of LBO target firms prior to LBO announcement to proxy for growth prospects of LBO targets. However, there is an insignificant relation found between growth prospects and premiums in LIBOs/LMBOs over the sub period 2000-2005. Lehn and Poulsen (1989) have a similar finding for the effects of growth prospects on LBO premiums in the 1980s. Therefore, the above results fail to support that growth potential of LBO target firms were appreciated by acquirers of LIBOs and LMBOs over the sub period 2000-2005.

To further explore the interaction effects of LBO type dummy variable with the firmspecific variables, this study performs two separate OLS regressions for LIBOs and LMBOs over the sub period 2000-2005 (Results are presented in Table 5.6). 
Table 5.6: Separate OLS Regression on LBO Premiums for LIBOs and LMBOs over the Sub Period 2000-2005

"Premiums 1 Week prior to LBO Announcement", “Investment Opportunities (Tobin's Q)", "Scaled Undistributed Free Cash Flow", "3 Year Average Dividend Payout Ratio", and "Managerial Ownership are included in the following analyses.

Outliers are detected using Weisberg t-test statistic. Some outliers are deleted after careful assessments as there are some values that seem documented wrongly in the database or are too high or low to make any financial sense.

The results reported subsequently are obtained using "(EBITDA-Tax-Interests-Dividends)/Net Sales" as the proxy for the pre-buyout level of free cash flow and using "Premiums 1 Week prior to LBO Announcement" as the proxy for the LBO premiums.

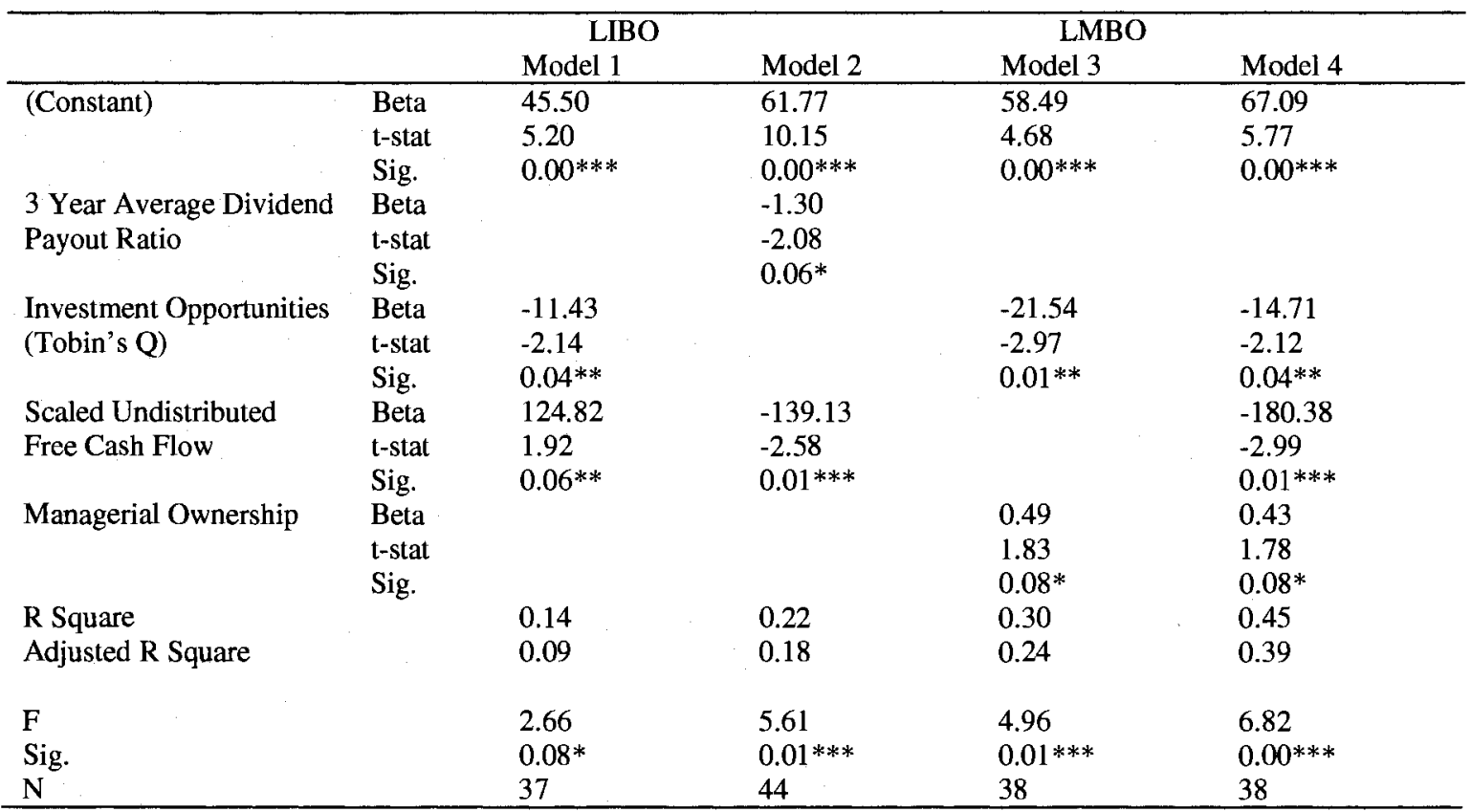

Note (1): *,*, and *** indicates statistical significance at 10\%, 5\%, and $1 \%$ levels respectively.

(2): This study obtains similar results using an alternate measure of pre-buyout level of free cash flow (Cash Flow from Operations-Capital Expenditure-Net changes in working capital)/Net Sales.

(3): This study does not find sales growth rate has a significant coefficient when it is included, though it has a negative sign.

(4): When this study uses premiums 4 week as dependent variable, this study has an insignificant negative coefficient on dividend payout ratio. Thus, the above result on the significantly negative relation between dividend payout ratio and $L B O$ premiums is not robust. 
The results of the separate regression models for LIBOs and LMBOs (presented in Table 5.6) are consistent with the findings of the pooled regression models for LBOs (presented in Table 5.5). Table 5.6 shows opposite signs of the coefficients on the free cash flow variable for LIBOs and LMBOs. For LIBOs, this study finds a significant and positive relation between the free cash flow variable and LIBO premiums. In contrast, for LMBOs, there is a significant and negative relation found between the free cash flow variable and LMBO premiums. ${ }^{50}$ Furthermore, when comparing the findings of the separate OLS regressions on LBO premiums for LIBOs and LMBOs in the 1990s (presented in Table 5.4) with the results over the sub period 2000-2005 (presented in Table 5.6), this study identifies that the main difference in results over the two sub periods lies in the effects of free cash flow on LMBO premiums.

To explore Halpern et al (1999)'s heterogeneity hypothesis, this study further divides LMBOs into two sub groups: LMBOs with higher levels of pre-buyout managerial ownership than industry peers and LMBOs with lower levels of pre-buyout managerial ownership than industry peers. Separate OLS regressions on LBO premiums for these two sub groups of LMBOs are performed and results are presented in Table 5.7. For the firms with lower levels of managerial ownership, there is a significant and negative relation between the free cash flow variable and LBO premiums. For the firms with higher levels of managerial ownership, there is a negative, but insignificant relation between the free cash flow variable and LBO premiums. Thus, the free cash flow hypothesis for LMBOs with lower levels of pre-buyout managerial ownership is rejected.

\footnotetext{
${ }^{50}$ The possibility that LMBO firms with better financial performance still follow the free cash flow hypothesis is excluded, since this study does not find a positive relation between the premiums and the free cash flow variable for LMBOs with higher levels of pre-buyout free cash flows.
} 
These findings imply that the LMBO populations may be heterogeneous in managerial ownership over the sub period 2000-2005.

\section{Table 5.7: Separate OLS Regression on LBO Premiums for LMBOs with Higher Level of Pre-buyout Managerial Ownership and LMBOs with Lower Level of Pre- buyout Managerial Ownership over the Sub Period 2000-2005}

"Investment Opportunities (Tobin's Q)" and "Scaled Undistributed Free Cash Flow" are included in the following analyses.

Outliers are detected using Weisberg t-test statistic. Some outliers are deleted after careful assessments as there are some values that seem documented wrongly in the database or are too high or low to make any financial sense.

The results reported subsequently are obtained using "(EBITDA-Tax-Interests-Dividends)/Net Sales" as the proxy for the pre-buyout level of free cash flow and using "Premiums 1 Week prior to LBO Announcement" as the proxy for the LBO premiums.

\begin{tabular}{|c|c|c|c|c|c|c|}
\hline \multirow[t]{2}{*}{ Variable } & & \multicolumn{2}{|c|}{$\begin{array}{l}\text { Managerial Ownership } \\
\text { Difference }>=0\end{array}$} & \multicolumn{3}{|c|}{ Managerial Ownership Difference $<0$} \\
\hline & & Model 1 & Model 2 & Model 3 & Model 4 & Model 5 \\
\hline \multirow[t]{3}{*}{ Constant } & Beta & 60.98 & 59.58 & 57.68 & 80.10 & 83.05 \\
\hline & t-stat & 4.72 & 7.87 & 6.82 & 8.38 & 9.75 \\
\hline & Sig. & $0.00 * * *$ & $0.00 * * *$ & $0.00^{* * *}$ & $0.00 * * *$ & $0.00 * * *$ \\
\hline Scaled Undistributed & Beta & -110.38 & -113.39 & -194.47 & & -115.97 \\
\hline Free & $\mathrm{t}$-stat & -1.52 & -1.70 & -2.55 & & -2.12 \\
\hline Cash Flow & Sig. & 0.15 & 0.11 & $0.03 * *$ & & $0.06^{*}$ \\
\hline Investment Opportunities & Beta & -1.56 & & & -43.04 & -36.09 \\
\hline \multirow[t]{2}{*}{ (Tobin's Q) } & t-stat & -0.14 & & & -4.48 & -3.98 \\
\hline & Sig. & 0.89 & & & $0.00 * * *$ & $0.00 * * *$ \\
\hline R Square & & 0.04 & 0.17 & 0.35 & 0.63 & 0.73 \\
\hline Adjusted R Square & & 0.03 & 0.11 & 0.30 & 0.59 & 0.69 \\
\hline $\mathrm{F}$ & & 1.35 & 2.88 & 6.51 & 20.04 & 15.20 \\
\hline Sig. & & 0.29 & 0.11 & $0.03 * *$ & $0.00 * * *$ & $0.00 * * *$ \\
\hline $\mathbf{N}$ & & 16 & 16 & 14 & 14 & 14 \\
\hline
\end{tabular}

Note (1):*,**, and *** indicates statistical significance at $10 \%, 5 \%$, and $1 \%$ levels respectively.

(2): This study obtains similar results using an alternate measure of pre-buyout level of free cash flow (Cash Flow from Operations-Capital Expenditure-Net changes in working capital)/Net Sales. 
A summary of the empirical results with respect to the factors explaining the premiums paid for LIBOs and LMBOs over the period 1985-2005 are presented in Table 5.8. As expected, the sources of value created throughout LMBOs had significantly changed over the period 1985-2005, while the sources of high premiums in LIBOs had been consistently from the free cash flow explanation. Also, as expected, the value sources of LIBOs and LMBOs are different over the sub period 2000-2005. Thus, the value sources of LBOs are period specific and LBO type dependent. 


\section{Table 5.8 Summary of Factors Explaining Premiums Paid to Shareholders of LIBOs and LMBOs}

\begin{tabular}{|c|c|c|c|c|c|}
\hline Issue & Hypothesis & $\begin{array}{l}\text { Sign } \\
\text { Expec } \\
\text { ted }\end{array}$ & Period & Result & Implications \\
\hline \multirow[t]{2}{*}{ Relative P/E } & \multirow{2}{*}{$\begin{array}{l}\text { Hypothesis P1: The lower } \\
\text { the company's P/E ratio } \\
\text { compared to the industry } \\
\text { peer firms, the higher } \\
\text { premiums paid to LMBOs } \\
\text { and LIBOs. }\end{array}$} & \multirow[t]{2}{*}{-} & 1990-1999 & - Insignificant & Fail to support \\
\hline & & & $2000-2005$ & + Insignificant & Fail to support \\
\hline \multirow{2}{*}{$\begin{array}{l}\text { Volatility of } \\
\text { cash flow }\end{array}$} & \multirow{2}{*}{$\begin{array}{l}\text { Hypothesis P2: Higher } \\
\text { premiums are paid for } \\
\text { LMBOs and LIBOs with } \\
\text { lower volatility of free cash } \\
\text { flow. }\end{array}$} & \multirow[t]{2}{*}{-} & 1990-1999 & - Insignificant & Fail to support \\
\hline & & & $2000-2005$ & + Insignificant & Fail to support \\
\hline \multirow{2}{*}{$\begin{array}{l}\text { Dividend } \\
\text { payout ratio }\end{array}$} & \multirow{2}{*}{$\begin{array}{l}\text { Hypothesis P3: Higher } \\
\text { premiums are paid for } \\
\text { LMBOs and LIBOs with } \\
\text { higher dividend payout } \\
\text { ratio. }\end{array}$} & \multirow[t]{2}{*}{+} & 1990-1999 & + Significant & Support \\
\hline & & & $2000-2005$ & - Insignificant & Fail to support \\
\hline \multirow{3}{*}{$\begin{array}{l}\text { Investment } \\
\text { opportunities }\end{array}$} & \multirow{3}{*}{$\begin{array}{l}\text { Hypothesis P4: Higher } \\
\text { premiums are paid for } \\
\text { LMBOs and LIBOs with } \\
\text { less quality of investment } \\
\text { opportunities. }\end{array}$} & \multirow[t]{3}{*}{ - } & 1985-1989 & - Significant & Support \\
\hline & & & 1990-1999 & - Significant & Support \\
\hline & & & $2000-2005$ & - Significant & Support \\
\hline \multirow{3}{*}{$\begin{array}{l}\text { Challenged } \\
\text { deals }\end{array}$} & \multirow{3}{*}{$\begin{array}{l}\text { Hypothesis P5: Higher } \\
\text { premiums are paid for } \\
\text { LMBOs and LIBOs when } \\
\text { there are challenged deals. }\end{array}$} & \multirow[t]{3}{*}{+} & $1985-1989$ & + Insignificant & Fail to support \\
\hline & & & 1990-1999 & + Insignificant & Fail to support \\
\hline & & & $2000-2005$ & + Insignificant & Fail to support \\
\hline \multirow{3}{*}{$\begin{array}{l}\text { Tax } \\
\text { expenditures }\end{array}$} & \multirow{3}{*}{$\begin{array}{l}\text { Hypothesis P6: Higher } \\
\text { premiums are paid for } \\
\text { LMBOs and LIBOs with } \\
\text { higher tax expenditures. }\end{array}$} & \multirow[t]{3}{*}{+} & $1985-1989$ & - Insignificant & Fail to support \\
\hline & & & $1990-1999$ & - Insignificant & Fail to support \\
\hline & & & $2000-2005$ & - Insignificant & Fail to support \\
\hline \multirow[t]{3}{*}{ Free cash flow } & \multirow{3}{*}{$\begin{array}{l}\text { Hypothesis P7: Higher } \\
\text { premiums are paid for } \\
\text { LMBOs and LIBOs with } \\
\text { higher pre-buyout levels of } \\
\text { free cash flow. }\end{array}$} & \multirow[t]{3}{*}{+} & 1985-1989 & + Insignificant & Fail to support \\
\hline & & & $1990-1999$ & + Significant & Support \\
\hline & & & $2000-2005$ & - Insignificant & Fail to support \\
\hline \multirow{2}{*}{$\begin{array}{l}\text { Managerial } \\
\text { ownership* } \\
\text { LBO type } \\
\text { Dummy }\end{array}$} & \multirow{2}{*}{$\begin{array}{l}\text { Hypothesis P8: Higher } \\
\text { premiums are paid for } \\
\text { LMBOs with lower pre- } \\
\text { buyout levels of managerial } \\
\text { ownership and LIBOs with } \\
\text { higher pre-buyout levels of } \\
\text { managerial ownership. }\end{array}$} & \multirow[t]{2}{*}{-} & $1990-1999$ & - Insignificant & Fail to support \\
\hline & & & $2000-2005$ & + Insignificant & Fail to support \\
\hline $\begin{array}{l}\text { Free cash flow } \\
\text { * LBO type } \\
\text { Dummy }\end{array}$ & $\begin{array}{l}\text { Hypothesis P9: Higher } \\
\text { premiums are paid for } \\
\text { LMBOs with lower } \\
\text { undistributed free cash flow } \\
\text { and LIBOs with higher } \\
\text { undistributed free cash flow }\end{array}$ & - & $2000-2005$ & - Significant & Support \\
\hline
\end{tabular}


Chapter 6: Results: Explanatory Factors of the Likelihood of Firms' Going Private via LIBOs or LMBOs

This chapter presents the results for explanatory factors of the likelihood of firms' going private via LIBOs or LMBOs over the period 1985-2005. Section 6.1 describes the differences in firm-specific variables between LBOs (including LMBOs and LIBOs) and their industry peers (also called 1-1 matched non-LBO control firms in this study). Section 6.2 provides the results regarding the explanatory factors of the likelihood of firms' going private via LIBOs or LMBOs over the three sub periods (namely, 19851989, 1990-1999, and 2000-2005). Section 6.3 compares the results between standard logistic regression and conditional logistic regression and explains the reasons for the differences in the results.

\subsection{Differentiating Characteristics between LBOs and 1-1 Matched Control Firms}

This section first compares the firm-specific and deal-specific variables between LBOs and their industry peers over the period 1985-2005 using paired t-tests. The results of the paired t-tests are presented in Panel A of Table 6.1. Afterwards, the differences between LIBOs and their control firms over the period 1995-2005 along with the differences between LMBOs and their industry peers over the period 1985-2005 are examined separately. The corresponding results of the paired t-tests for LIBOs and LMBOs are presented in Panel B and C of Table 6.1. 
Table 6.1 Univariate Analysis for Differences between LBOs (including LIBOs and LMBOs) and Control Firms

"Volatility of Cash Flow", "P/E", "Premiums 1 Week prior to LBO Announcement", "Investment Opportunities (Tobin's Q)", "Undistributed Free Cash Flow", "Tax Expenditures", "3 Year Average Dividend Payout Ratio", "Net Sales", and "Managerial Ownership" are included in the following analyses.

Paired t-tests are performed.

Panel A: Comparison between LBOs (including LIBOs and LMBOs) and Control Sample over the period 1985-2005

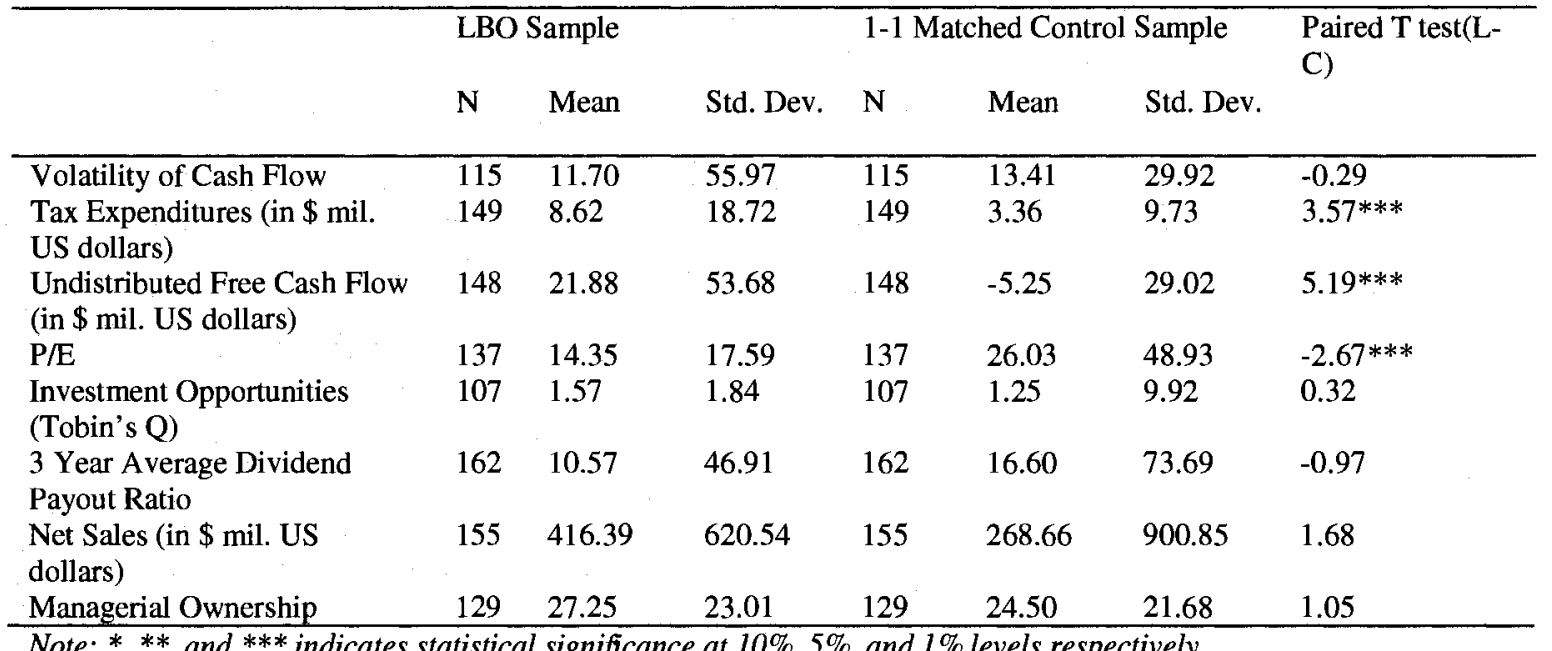

Panel B Comparison between LIBOs and Control Sample over the period 1995-2005

\begin{tabular}{|c|c|c|c|c|c|c|c|}
\hline & \multicolumn{3}{|c|}{ LIBO Sample } & \multicolumn{3}{|c|}{ 1-1 Matched Control Sample } & \multirow{2}{*}{$\begin{array}{l}\text { Paired } T \text { test }(L- \\
\text { C) }\end{array}$} \\
\hline & $\mathrm{N}$ & Mean & Std. Dev. & $\mathrm{N}$ & Mean & Std. Dev. & \\
\hline Volatility of Cash Flow & 46 & 5.04 & 4.85 & 46 & 9.71 & 16.21 & $-2.02 * *$ \\
\hline $\begin{array}{l}\text { Tax Expenditures (in } \$ \text { mil. } \\
\text { US dollars) }\end{array}$ & 46 & 13.62 & 24.45 & 46 & 5.28 & 8.74 & $2.33 * *$ \\
\hline $\begin{array}{l}\text { Undistributed Free Cash Flow } \\
\text { (in \$ mil. US dollars) }\end{array}$ & 46 & 34.84 & 75.44 & 46 & -11.85 & 32.26 & $4.04 * * *$ \\
\hline $\mathrm{P} / \mathrm{E}$ & 48 & 13.58 & 21.68 & 48 & 29.26 & 46.83 & $-2.19 * *$ \\
\hline $\begin{array}{l}\text { Investment Opportunities } \\
\text { (Tobin's Q) }\end{array}$ & 47 & 2.27 & 2.31 & 47 & 0.10 & 14.45 & 1.00 \\
\hline $\begin{array}{l}3 \text { Year Average Dividend } \\
\text { Payout Ratio }\end{array}$ & 47 & 15.25 & 63.93 & 47 & 27.42 & 109.99 & -0.75 \\
\hline $\begin{array}{l}\text { Net Sales (in \$ mil. US } \\
\text { dollars) }\end{array}$ & 104 & 304.07 & 44.31 & 104 & 202.64 & 89.03 & 1.48 \\
\hline Managerial Ownership & 57 & 21.15 & 18.66 & 57 & 23.35 & 23.75 & -0.57 \\
\hline
\end{tabular}


Panel C Comparison between LMBOs and Control Sample over the period 1985-2005

\begin{tabular}{|c|c|c|c|c|c|c|c|}
\hline & \multicolumn{3}{|c|}{ LMBO Sample } & \multicolumn{3}{|c|}{ 1-1 Matched Control Sample } & \multirow{2}{*}{$\begin{array}{l}\text { Paired T test(L- } \\
\text { C) }\end{array}$} \\
\hline & $\mathbf{N}$ & Mean & Std. Dev. & $\mathbf{N}$ & Mean & Std. Dev. & \\
\hline Volatility of Cash Flow & 69 & 16.13 & 72.02 & 69 & 15.87 & 36.21 & 0.03 \\
\hline $\begin{array}{l}\text { Tax Expenditures (in } \$ \text { mil. } \\
\text { US dollars) }\end{array}$ & 103 & 6.39 & 15.11 & 103 & 2.51 & 10.06 & $2.77 * * *$ \\
\hline $\begin{array}{l}\text { Undistributed Free Cash Flow } \\
\text { (in } \$ \text { mil. US dollars) }\end{array}$ & 102 & 16.05 & 39.34 & 102 & -2.28 & 27.08 & $3.43^{* * *}$ \\
\hline $\mathrm{P} / \mathrm{E}$ & 89 & 14.77 & 15.05 & 89 & 24.28 & 50.20 & $-1.72 *$ \\
\hline $\begin{array}{l}\text { Investment Opportunities } \\
\text { (Tobin's Q) }\end{array}$ & 60 & 1.03 & 1.10 & 60 & 2.16 & 3.49 & $-2.41 * *$ \\
\hline $\begin{array}{l}3 \text { Year Average Dividend } \\
\text { Payout Ratio }\end{array}$ & 115 & 8.66 & 38.03 & 115 & 12.18 & 52.14 & -0.61 \\
\hline $\begin{array}{l}\text { Target Net Sales (in } \$ \text { mil. US } \\
\text { dollars) }\end{array}$ & 146 & 308.21 & 477.23 & 140 & 219.80 & 844.32 & 1.07 \\
\hline Managerial Ownership & 72 & 32.09 & 25.03 & 72 & 25.41 & 20.02 & $1.90^{*}$ \\
\hline
\end{tabular}

Panel A of Table 6.1 shows that compared to industry peers, LBOs (including both LIBOs and LMBOs) have significantly higher tax expenditures and levels of undistributed/distributed free cash flow, and significantly lower P/E ratio over the period 1985-2005. Panel B and C of Table 6.1 show the similar findings, except 1) LMBOs are found to have significantly higher managerial ownership and significantly lower investment opportunities than industry peers; 2) LIBOs are found to have significantly lower volatility of cash flow than industry peers. Note that most of these variables are identified as determinants of the likelihood of firms' going private via LBO in the previous research. Thus it is not surprising to see that there are significant differences in these variables between LBOs and control firms, even though LBOs are matched with control firms by industry SIC code and firm size in this study. 


\subsection{Conditional Logistic Regression on the Likelihood of Firms' Going Private via LBOs}

This section describes the results of conditional logistic regression on the likelihood of firms' going private via LMBOs and LIBOs over the three sub periods. Some interaction terms (especially the interaction between managerial ownership and LBO type dummy variable) are included in regression models to reflect the hypothesized different motivations behind LIBOs and LMBOs. The findings of conditional logistic regression models on the likelihood of firms' going private via LMBOs and LIBOs over the three sub periods are presented in Table 6.2 (Panel A, B, and C). 


\section{Table 6.2: Conditional Logistic Regression on the Likelihood of Firms' Going Private via LMBOs and LIBOs over Three Sub Periods}

"Volatility of Cash Flow", "P/E", "Investment Opportunities (Tobin's Q)", "firm-specific variables *LBO Type Dummy", "Undistributed Free Cash Flow", "Tax Expenditures", "3 Year Average Dividend Payout Ratio", and "Managerial Ownership are included in the following analyses.

Outliers are detected using Weisberg t-test statistic. Some outliers are then deleted after careful assessments as there are some values that seem documented wrongly in the database or are too high or low to make any financial sense.

The results reported subsequently are obtained using "EBITDA-Tax-Interests-Dividends" as the proxy for the prebuyout level of free cash flow.

The following analysis is accomplished using software SPSS 15.

Panel A: Conditional logistic regression on the likelihood of firms' going private via LMBOs over the sub period 1985-1989

\begin{tabular}{lllll}
\hline & & Model 1 & Model 2 & Model 3 \\
\hline Undistributed Free Cash Flow & Beta & 0.01 & 0.00 & 0.00 \\
& Exp(B) & 1.01 & 1.00 & 1.00 \\
& Sig. & $0.02 * *$ & 0.35 & 0.59 \\
Tax Expenditures & Beta & 0.01 & 0.01 & \\
& Exp(B) & 1.01 & 1.01 & \\
3 Year Average Dividend Payout Ratio & Sig. & 0.43 & 0.11 & \\
& Beta & 0.01 & & 57 \\
& Exp(B) & 1.00 & & \\
N & Sig. & 0.38 & & 78.73 \\
2-log likelihood & & & & 0.01 \\
Cox \& Shell R Square & & 38 & 54 & 0.00 \\
McFadden R Square & & 44.35 & 71.71 & 0.29 \\
Chi-square & & 0.20 & 0.06 & 1 \\
df & & 0.16 & 0.04 & 0.59 \\
Sig. & & 8.33 & 3.15 & 2 \\
\hline
\end{tabular}

Note $(1): *, * *$, and $* * *$ indicates statistical significance at $10 \%, 5 \%$, and $1 \%$ levels respectively.

(2); This study does not find sales growth rate to be significant when it is included.

(3): This study obtains similar results using an alternate measure of the pre-buyout level of free cash flow (Cash Flow from Operations-Capital Expenditure-Net changes in working capital).

(4): The goodness of fit statistics reported by the Multinomial Logistic Regression procedure doesn't work for matched case-control studies. This is because the dependent variable only takes one value, thus the observed and predicted frequencies table can never be properly filled out. But model fitting information is still valid: Since the significance level of the test is less than 0.05, this study can conclude the Final model is outperforming the Null. The cross tabulation table is also invalid for matched case-control studies, for the same reason as the goodness-of-fit tests. The likelihood ratio and $r$-squared statistics are valid for matched case-control studies. Since the stepwise methods are based on likelihood statistics, they are also valid. For these kinds of models, the Exp $(B)$ column reports the change in the odds of a claim for a one-unit change in the predictor. 
Panel B Conditional logistic regression on the likelihood of firms' going private via LMBOs and LIBOs over the sub period 1990-1999

\begin{tabular}{|c|c|c|c|c|c|}
\hline & & Model 1 & Model 2 & Model 3 & Model 4 \\
\hline \multirow[t]{3}{*}{ Undistributed Free Cash Flow } & Beta & & 0.05 & 0.05 & 0.04 \\
\hline & $\operatorname{Exp}(B)$ & & 1.05 & 1.06 & 1.04 \\
\hline & Sig. & & $0.01 * * *$ & $0.03 * *$ & $0.04 * *$ \\
\hline \multirow[t]{3}{*}{$\mathrm{P} / \mathrm{E}$} & Beta & -0.02 & -0.03 & -0.03 & \\
\hline & $\operatorname{Exp}(B)$ & 0.98 & 0.97 & 0.97 & \\
\hline & Sig. & $0.06^{*}$ & $0.10^{*}$ & $0.06^{*}$ & \\
\hline \multirow[t]{3}{*}{ Volatility of Cash Flow } & Beta & & -0.08 & & \\
\hline & $\operatorname{Exp}(B)$ & & 0.93 & & \\
\hline & Sig. & & 0.20 & & \\
\hline Investment Opportunities & Beta & -0.09 & & & 0.04 \\
\hline \multirow{2}{*}{ (Tobin's Q) } & $\operatorname{Exp}(B)$ & 0.92 & & & 1.04 \\
\hline & Sig. & 0.26 & & & 0.64 \\
\hline \multirow[t]{3}{*}{ Tax Expenditures } & Beta & & & & 0.06 \\
\hline & $\operatorname{Exp}(B)$ & & & & 1.06 \\
\hline & Sig. & & & & 0.29 \\
\hline Managerial Ownership* LBO & Beta & & & 0.00 & \\
\hline \multirow[t]{2}{*}{ Type Dummy } & $\operatorname{Exp}(B)$ & & & 1.00 & \\
\hline & Sig. & & & 0.89 & \\
\hline $\mathbf{N}$ & & 41 & 34 & 31 & 32 \\
\hline 2-log likelihood & & 51.59 & 29.256 & 30.825 & 35.527 \\
\hline Cox \& Shell R Square & & 0.12 & .409 & 0.32 & 0.24 \\
\hline McFadden R Square & & 0.09 & .379 & 0.28 & 0.20 \\
\hline Chi-square & & 5.24 & 17.88 & 12.15 & 8.83 \\
\hline df & & 2 & 3 & 3 & 3 \\
\hline Sig. & & $0.07 *$ & $0.00 * * *$ & $0.01 * * *$ & $0.03^{* *}$ \\
\hline
\end{tabular}

Note (1): *,**, and *** indicates statistical significance at $10 \%, 5 \%$, and $1 \%$ levels respectively.

(2); This study does not find sales growth rate to be significant when it is included.

(3): This study obtains similar results using an alternate measure of the pre-buyout level of free cash flow (Cash Flow from Operations-Capital Expenditure-Net changes in working capital).

(4): Interaction term of LBO type with undistributed free cash flow is not found significant.

(5): 3 year dividend payout ratio is not found significant. 
Panel C: Conditional logistic regression on the likelihood of firms' going private via LMBOs and LIBOs over the sub period 2000-2005

\begin{tabular}{|c|c|c|c|c|c|}
\hline Variable & & Model 1 & Model 2 & Model 3 & Model 4 \\
\hline \multirow[t]{3}{*}{ Undistributed Free Cash Flow } & Beta & 0.03 & 0.03 & 0.02 & 0.03 \\
\hline & $\operatorname{Exp}(B)$ & 1.03 & 1.03 & 1.02 & 1.03 \\
\hline & Sig. & $0.00 * * *$ & $0.00 * * *$ & $0.00 * * *$ & $0.00^{* * *}$ \\
\hline \multirow{4}{*}{ Volatility of Cash Flow } & Beta & 0.00 & -0.10 & -0.06 & \\
\hline & $\operatorname{Exp}(B)$ & 1.00 & 0.91 & 0.94 & \\
\hline & Sig. & 0.87 & $0.03 * *$ & $0.03 * *$ & \\
\hline & Beta & 0.06 & & 0.04 & 0.05 \\
\hline \multirow[t]{2}{*}{ Tax Expenditures } & $\operatorname{Exp}(B)$ & 1.07 & & 1.04 & 1.06 \\
\hline & Sig. & $0.00^{* * *}$ & & $0.00^{* * *}$ & $0.00^{* * *}$ \\
\hline Investment Opportunities & Beta & -0.15 & & -0.14 & -0.14 \\
\hline \multirow[t]{2}{*}{ (Tobin's Q) } & $\operatorname{Exp}(B)$ & 0.86 & & 0.87 & 0.87 \\
\hline & Sig. & $0.05^{* *}$ & & 0.12 & $0.06 *$ \\
\hline 3 Year Average Dividend Payout & Beta & 0.00 & -0.01 & & \\
\hline \multirow[t]{2}{*}{ Ratio } & $\operatorname{Exp}(B)$ & 1.00 & 0.99 & & \\
\hline & Sig. & 0.72 & 0.49 & & \\
\hline \multirow[t]{4}{*}{ Managerial Ownership } & Beta & 0.00 & & & \\
\hline & $\operatorname{Exp}(B)$ & 1.00 & & & \\
\hline & Sig. & 0.96 & & & \\
\hline & Beta & & -0.01 & 0.00 & \\
\hline \multirow[t]{2}{*}{$\mathrm{P} / \mathrm{E}$} & $\operatorname{Exp}(B)$ & & 0.99 & 1.00 & \\
\hline & Sig. & & 0.57 & 0.60 & \\
\hline Managerial Ownership *LBO & Beta & & & & 0.03 \\
\hline \multirow[t]{2}{*}{ Type Dummy } & $\operatorname{Exp}(B)$ & & & & 1.03 \\
\hline & Sig. & & & & $0.06^{*}$ \\
\hline $\mathbf{N}$ & & 47 & 59 & 52 & 44 \\
\hline 2-log likelihood & & 44.09 & 46.54 & 43.02 & 38.48 \\
\hline Cox \& Shell R Square & & 0.36 & 0.45 & 0.43 & 0.40 \\
\hline McFadden R Square & & 0.32 & 0.43 & 0.40 & 0.37 \\
\hline Chi-square & & 21.06 & 35.25 & 29.07 & 22.52 \\
\hline df & & 6 & 5 & 5 & 4 \\
\hline Sig. & & $0.00 * * *$ & $0.00 * * *$ & $0.00 * * *$ & $0.00 * * *$ \\
\hline
\end{tabular}

Note (1): *,**, and *** indicates statistical significance at $10 \%, 5 \%$, and $1 \%$ levels respectively.

(2): This study does not find that sales growth rate has a significant coefficient when it is included.

(3): An interaction between LBO type dummy and undistributed free cash flow is not found significant.

(4): This study obtains similar results using an alternate measure of the pre-buyout level of free cash flow (Cash Flow from Operations-Capital Expenditure-Net changes in working capital). 
In terms of the results of conditional logistic regressions on the likelihood of firms' going private via LBOs over the period $1985-2005$, this study has the following major findings:

1) Over the sub period $1985-1989$, none of the firm-specific variables is found significant in explaining the likelihood of firms' undertaking LMBOs. This conclusion is consistent with the findings of this study over the sub period 1985-1989 described in Chapter 5. But it is inconsistent with the conclusions of Lehn and Poulsen (1989), Opler and Titman (1993), and Maupin et al. (1984). This could be attributed to their misleading statistical methods, biased proxies for their free cash flow variable, and different research periods of the previous studies: For example, Lehn and Poulsen (1989) wrongly use standard logistic regression to process the data collected by 1-1 matched case-control sampling design. Their proxy for the free cash flow variable scaled by market value may bias the results (Kieschnick, 1998). As noted earlier, the proxies for the free cash flow variable adopted by Maupin et al (1984) and Opler and Titman (1993) are also misleading: The cash dividends are wrongly included in their proxies. Moreover, Maupin et al (1984)'s research is based on MBOs completed over the period 1972-1983 when the LBO market was not overheated, while this research is based on the LMBOs over the sub period 19851989.

2) Over the sub period 1990-1999, this study has similar findings on the effects of LBO firms' free cash flows to the results described in Chapter 5. This study finds that firms with more free cash flows prior to LBOs are more likely to go private via LMBOs or LIBOs in the 1990s. Also, consistent with the findings presented in the previous chapters, 
this study does not find any significant interaction terms, which implies that the motivations are not different between LIBOs and LMBOs in the 1990s.

Over the sub period 1990-1999, this study has an interesting finding on the market undervaluation effect: Instead of Tobin's $\mathrm{Q}, \mathrm{P} / \mathrm{E}$ ratio is found to have a significant and negative relation with the likelihood of firms' going private via LBOs. This finding provides support for the market undervaluation hypothesis. It is also consistent with the practice that most of the acquirers regard low $\mathrm{P} / \mathrm{E}$ as the most important reason for taking the firms' going private via LBOs (Maupin et al, 1984). One of the possible reasons why the market undervaluation effect is identified only over the sub period 1990-1999 can be explained by the overheated market hypothesis. Irrational acquirers may tend to pay less attention to the undervaluation of LBO target firms in the overheated LBO market. However, when the overheated market cooled off in the 1990s, as the result of Maupin et al (1984)'s survey indicates, it is more likely that acquires of LBO targets take market undervaluation into consideration.

3) Over the sub period $2000-2005$, this study finds that firms with higher levels of managerial ownership are more likely to undertake LMBOs, while firms with lower levels of managerial ownership are more likely to go private via LIBOs. This is consistent with Halpern et al (1999)'s heterogeneity hypothesis.

Since differences in deal characteristics and value sources between LIBOs and LMBOs are identified only over the sub period 2000-2005 in the previous Chapters, separate 
conditional logistic regressions for LIBOs and LMBOs are performed over the sub period 2000-2005 in order to further explore different motivations behind LIBOs and LMBOs.

The corresponding findings are presented in Table 6.3.

Table 6.3: Separate Conditional Logistic Regression on the Likelihood of Firms' Going Private via LBOs for LIBOs and LMBOs over the Sub Period 2000-2005

"Volatility of Cash Flow", "P/E", "Investment Opportunities (Tobin's Q)", "Undistributed Free Cash Flow", and "Tax Expenditures" are included in the following analyses.

Outliers are detected using Weisberg t-test statistic. Some outliers are then deleted after careful assessments as there are some values that seem documented wrongly in the database or are too high or low to make any financial sense.

The results reported subsequently are obtained using "EBITDA-Tax-Interests-Dividends" as the proxy for the prebuyout level of free cash flow.

\begin{tabular}{|c|c|c|c|c|c|c|c|}
\hline & & \multicolumn{3}{|l|}{ LMBO } & \multicolumn{3}{|l|}{ LIBO } \\
\hline & & Model 1 & Model 2 & Model 3 & Model 1 & Model 3 & Model 4 \\
\hline Undistributed Free & Beta & & 0.00 & & 0.02 & 0.01 & \\
\hline \multirow[t]{2}{*}{ Cash Flow } & $\operatorname{Exp}(B)$ & & 1.00 & & 1.02 & 1.01 & \\
\hline & Sig. & & 0.42 & & $0.00 * * *$ & $0.01 * * *$ & \\
\hline Volatility of Cash & Beta & & & -0.11 & & & \\
\hline \multirow[t]{2}{*}{ Flow } & $\operatorname{Exp}(B)$ & & & 0.89 & & & \\
\hline & Sig. & & & $0.00 * * *$ & & & \\
\hline \multirow[t]{3}{*}{ Tax Expenditures } & Beta & 0.06 & & & & & 0.00 \\
\hline & $\operatorname{Exp}(B)$ & 1.06 & & & & & 1.00 \\
\hline & Sig. & $0.02 * *$ & & & & & 0.75 \\
\hline Investment & Beta & & -0.99 & & -0.39 & & \\
\hline Opportunities & $\operatorname{Exp}(B)$ & & 0.37 & & 0.67 & & \\
\hline (Tobin's Q) & Sig. & & $0.00 * * *$ & & $0.10^{*}$ & & \\
\hline Managerial & Beta & 0.04 & 0.03 & & -0.05 & & \\
\hline \multirow[t]{2}{*}{ ownership } & $\operatorname{Exp}(B)$ & 1.04 & 1.03 & & 0.95 & & \\
\hline & Sig. & $0.00^{* * *}$ & $0.06^{* *}$ & & $0.03^{* *}$ & & \\
\hline \multirow[t]{3}{*}{$\mathrm{P} / \mathrm{E}$} & Beta & & & -0.01 & & 0.00 & \\
\hline & $\operatorname{Exp}(B)$ & & & 0.99 & & 1.00 & \\
\hline & Sig. & & & 0.44 & & 1.00 & \\
\hline $\mathrm{N}$ & & 42 & 34 & 35 & 22 & 22 & 16 \\
\hline 2-log likelihood & & 45.82 & 34.04 & 32.91 & 17.02 & 23.86 & 17.12 \\
\hline Cox \& Shell R & & 0.26 & 0.32 & 0.36 & 0.46 & 0.26 & 0.27 \\
\hline Square & & & & & & & \\
\hline McFadden R Square & & 0.21 & 0.28 & 0.32 & 0.44 & 0.22 & 0.23 \\
\hline Chi-square & & 12.41 & 13.09 & 15.61 & 13.48 & 6.64 & 5.06 \\
\hline df & & 2 & 3 & 2 & 3 & 2 & 1 \\
\hline Sig. & & $0.00 * * *$ & $0.00^{* * *}$ & $0.00^{* * *}$ & $0.00^{* * *}$ & $0.04 * *$ & $0.08^{*}$ \\
\hline
\end{tabular}

Note (1): *,*, and *** indicates statistical significance at $10 \%, 5 \%$, and $1 \%$ levels respectively.

(2): This study obtains similar results when this study uses another measure for the pre-buyout level of free cash flow (Cash Flow from Operations-Capital Expenditure-Net changes in working capital). 
The findings of the two separate conditional logistic regressions (documented in Table 6.3) are intriguing: For LIBOs, this study finds a significant and positive relation between the odds of the firms' going LIBOs and the free cash flow variable; For LMBOs, the coefficient on the free cash flow variable is found insignificant. These different findings on the free cash flow variable for LIBOs and LMBOs further confirm the conclusion presented in Chapter 5 that the free cash flow hypothesis only holds for LIBOs over the sub period 2000-2005. The different effects of managerial ownership on the likelihood of firms' going private via LBOs between LIBOs and LMBOs are also confirmed in Table 6.3 .

To further explore the insignificant coefficient on the free cash flow variable for LMBOs, this study divides LMBO sample into two sub-samples by managerial ownership: LMBOs with higher levels of managerial ownership than their industry peers and LMBOs with lower levels of managerial ownership than their industry peers. This division is based on Halpern et al (1999)'s conclusion that LBO populations are heterogeneous in managerial ownership. Two separate regressions are performed on the free cash flow variable for these two groups of LMBOs over the sub period 2000-2005. Results are presented in Table 6.4. 
Table 6.4: Separate Conditional Logistic Regression on the Likelihood of the Two Groups of Firms Going Private via LMBOs over the Sub Period 2000-2005

"Volatility of Cash Flow", "Investment Opportunities (Tobin's Q)", "Undistributed Free Cash Flow", and "Tax Expenditures" are included in the following analyses.

The two groups of firms undertaking LMBOs include LMBO targets with higher pre-buyout levels of managerial ownership and LMBOs targets with lower pre-buyout levels of managerial ownership. These two groups are categorized according to managerial ownership differences between LMBOs and their industry peers.

Outliers are detected using Weisberg t-test statistic. Some outliers are then deleted after careful assessments as there are some values that seem documented wrongly in the database or are too high or low to make any financial sense.

The results reported subsequently are obtained using "EBITDA-Tax-Interests-Dividends" as the proxy for the prebuyout level of free cash flow.

\begin{tabular}{|c|c|c|c|c|c|}
\hline & & \multirow{2}{*}{$\begin{array}{l}\text { Managerial } \\
\text { Ownership } \\
\text { Difference }>=0 \\
\text { Model } 1\end{array}$} & \multicolumn{3}{|c|}{ Managerial Ownership Difference $<0$} \\
\hline & & & Model 2 & Model 3 & Model 4 \\
\hline Undistributed Free & Beta & 0.04 & 0.00 & & 0.00 \\
\hline Cash Flow & $\begin{array}{l}\operatorname{Exp}(B) \\
\text { Sig }\end{array}$ & $\begin{array}{l}1.05 \\
0.00 * * *\end{array}$ & $\begin{array}{l}1.00 \\
0.76\end{array}$ & & $\begin{array}{l}1.00 \\
0.78\end{array}$ \\
\hline Tax Expenditures & $\begin{array}{l}\text { Beta } \\
\text { Exp(B) } \\
\text { Sig. }\end{array}$ & & & $\begin{array}{l}0.36 \\
1.43 \\
0.00^{* * *}\end{array}$ & \\
\hline Volatility of Cash Flow & $\begin{array}{l}\text { Beta } \\
\text { Exp(B) } \\
\text { Sig. }\end{array}$ & & $\begin{array}{l}-0.23 \\
0.79 \\
0.08 *\end{array}$ & & \\
\hline $\begin{array}{l}\text { Investment Opportunities } \\
\text { (Tobin's Q) }\end{array}$ & $\begin{array}{l}\text { Beta } \\
\text { Exp(B) } \\
\text { Sig. }\end{array}$ & & $\begin{array}{l}-1.06 \\
0.35 \\
0.04^{* *}\end{array}$ & $\begin{array}{l}-2.18 \\
0.11 \\
0.01 * * *\end{array}$ & \\
\hline $\mathrm{N}$ & & 25 & 12 & 14 & 16 \\
\hline 2-log likelihood & & 25.37 & 9.95 & 8.54 & 22.10 \\
\hline Cox \& Shell R Square & & 0.31 & 0.43 & 0.54 & 0.01 \\
\hline McFadden R Square & & 0.27 & 0.40 & 0.56 & 0.00 \\
\hline $\begin{array}{l}\text { Chi-square } \\
\text { df } \\
\text { Sig. }\end{array}$ & & $\begin{array}{l}9.29 \\
1 \\
0.00 * * *\end{array}$ & $\begin{array}{l}6.69 \\
3 \\
0.08^{*}\end{array}$ & $\begin{array}{l}10.87 \\
2 \\
0.00 * * *\end{array}$ & $\begin{array}{l}0.08 \\
1 \\
0.78\end{array}$ \\
\hline
\end{tabular}

Note (1):*,**, and *** indicates statistical significance at $10 \%, 5 \%$, and $1 \%$ levels respectively.

(2): This study obtains similar results when this study uses another measure for the pre-buyout level of free cash flow (Cash Flow from Operations-Capital Expenditure-Net changes in working capital). 
According to Table 6.4, this study finds two groups of LMBOs that went private over the sub period 2000-2005: For the firms with higher levels of managerial ownership than their industry peers, there is a significant and positive relation found between the free cash flow variable and the likelihood of firms' going private via LMBOs; For the firms with lower levels of managerial ownership than their industry peers, the coefficient on the free cash flow variable remains insignificant. These findings imply that the LMBO populations were heterogeneous in managerial ownership over the sub period 2000-2005.

Overall, the above interesting findings on LIBOs and LMBOs over the sub period 20002005 provide implications for both the heterogeneity hypothesis and the free cash flow hypothesis. In terms of the free cash flow hypothesis, the above findings for Sub topic 3 further confirm the conclusion that the free cash flow hypothesis only holds for LIBOs over the sub period 2000-2005. In terms of the heterogeneity hypothesis, this study finds that the heterogeneity hypothesis holds for LBOs over the sub period 2000-2005. More importantly, the findings of this study (described in Table 6.4) imply that LMBOs over the sub period 2000-2005 were heterogeneous in managerial ownership. Moreover, the results in this chapter also suggest that the free cash flow hypothesis does not hold for LMBOs with lower levels of managerial ownership over the sub period 2000-2005.

In conclusion, a summary of the results for the factors explaining the likelihood of firm's going private via LBOs is presented in Table 6.5. Overall, this study finds that the motivations of firms' going private via LBOs have greatly changed over the period 19852005. Consistent with the findings described in Chapter $4 \& 5$, the empirical findings 
presented in this chapter further confirm our conclusions for the three key working theories of this study. The overheated market hypothesis holds over the sub period 19851989 and 2000-2005; The FCF hypothesis holds for both LIBOs and LMBOs over the sub period 1990-1999 (when the overheated LBO market cooled off) and only for LIBOs over the sub period 2000-2005; The heterogeneity hypothesis holds for LBOs only over the sub period 2000-2005. Additionally, there is an important new finding identified in this Chapter: The market undervaluation hypothesis is supported over the sub period 1990-1999. 
Table 6.5 Summary of Explanatory Factors of the Likelihood of Firms' Going Private via LIBOs or LMBOs

\begin{tabular}{|c|c|c|c|c|c|c|}
\hline \multirow[t]{3}{*}{ Issue } & \multirow{3}{*}{ Hypothesis } & \multirow{3}{*}{$\begin{array}{l}\text { Sign } \\
\text { Expec } \\
\text { ted } \\
\end{array}$} & \multicolumn{4}{|c|}{ Sub Period } \\
\hline & & & \multirow{2}{*}{$\begin{array}{l}1985- \\
1989 \\
\end{array}$} & \multirow{2}{*}{$\begin{array}{l}1990- \\
1999 \\
\end{array}$} & \multicolumn{2}{|l|}{$2000-2005$} \\
\hline & & & & & LMBO & LIBO \\
\hline $\mathrm{P} / \mathrm{E}$ & $\begin{array}{l}\text { Hypothesis L1: Firms with } \\
\text { lower P/E are more likely to } \\
\text { go private via LMBOs or } \\
\text { LIBOs. }\end{array}$ & - & N/A & Supported & $\begin{array}{l}\text { Fail to } \\
\text { support }\end{array}$ & $\begin{array}{l}\text { Fail to } \\
\text { support }\end{array}$ \\
\hline $\begin{array}{l}\text { Volatility } \\
\text { of cash } \\
\text { flow }\end{array}$ & $\begin{array}{l}\text { Hypothesis L2: Firms with } \\
\text { lower volatility of free cash } \\
\text { flow are more likely to go } \\
\text { private via LMBOs or } \\
\text { LIBOs. }\end{array}$ & - & N/A & Supported & Supported & Supported \\
\hline $\begin{array}{l}\text { Dividend } \\
\text { payout ratio }\end{array}$ & $\begin{array}{l}\text { Hypothesis L3: Firms with } \\
\text { higher dividend payout } \\
\text { ratios are more likely to go } \\
\text { private via LMBOs or } \\
\text { LIBOs. } \\
\end{array}$ & + & $\begin{array}{l}\text { Fail to } \\
\text { support }\end{array}$ & $\begin{array}{l}\text { Fail to } \\
\text { support }\end{array}$ & $\begin{array}{l}\text { Fail to } \\
\text { support }\end{array}$ & $\begin{array}{l}\text { Fail to } \\
\text { support }\end{array}$ \\
\hline $\begin{array}{l}\text { Investment } \\
\text { opportuniti } \\
\text { es }\end{array}$ & $\begin{array}{l}\text { Hypothesis L4: Firms with } \\
\text { lower investment } \\
\text { opportunities are more } \\
\text { likely to go private via } \\
\text { LMBOs or LIBOs. } \\
\end{array}$ & - & N/A & $\begin{array}{l}\text { Fail to } \\
\text { support }\end{array}$ & Supported & Supported \\
\hline $\begin{array}{l}\text { Tax } \\
\text { expenditure } \\
\text { s }\end{array}$ & $\begin{array}{l}\text { Hypothesis L5: Firms with } \\
\text { higher potential tax saving } \\
\text { are more likely to go private } \\
\text { via LMBOs or LIBOs. }\end{array}$ & + & $\begin{array}{l}\text { Fail to } \\
\text { support }\end{array}$ & Supported & Supported & $\begin{array}{l}\text { Fail to } \\
\text { support }\end{array}$ \\
\hline $\begin{array}{l}\text { Free cash } \\
\text { flow }\end{array}$ & $\begin{array}{l}\text { Hypothesis L6: Firms with } \\
\text { higher pre-buyout levels of } \\
\text { free cash flow are more } \\
\text { likely to go private via } \\
\text { LMBOs or LIBOs. }\end{array}$ & + & $\begin{array}{l}\text { Fail to } \\
\text { support }\end{array}$ & Supported & $\begin{array}{l}\text { Fail to } \\
\text { support }\end{array}$ & Supported \\
\hline $\begin{array}{l}\text { Managerial } \\
\text { ownership }\end{array}$ & $\begin{array}{l}\text { Hypothesis L7: Firms with } \\
\text { lower pre-buyout levels of } \\
\text { managerial ownership are } \\
\text { more likely to go private via } \\
\text { LIBOs and firms with } \\
\text { higher pre-buyout levels of } \\
\text { managerial ownership are } \\
\text { more likely to go private via } \\
\text { LMBOs. }\end{array}$ & $\begin{array}{l}\text { Nonli } \\
\text { near }\end{array}$ & N/A & $\begin{array}{l}\text { Fail to } \\
\text { support }\end{array}$ & Supported & Supported \\
\hline
\end{tabular}




\subsection{Comparison of the Results between Standard Logistic Regression and}

Conditional Logistic Regression

This section compares the results of conditional logistic regression with those of standard logistic regression to emphasize advantages of conditional logistic regression over standard logistic regression. The results of these two statistical methods on the 1-1 matched case-control sample of this study are compared. Regression on the likelihood of firms' going private via LIBOs and LMBOs in the 19990s is taken as a specific example. Both standard logistic regression and conditional logistic regression include the same set of the variables in each regression model. The corresponding results are presented in Table 6.6. 
Table 6.6 Comparison of the Results between Standard Logistic Regression and Conditional Logistic Regression for Factors Explaining the Likelihood of Firms' Going Private via LBOs in the 1990s

"Volatility of Cash Flow", "P/E", "Investment Opportunities (Tobin's Q)", "Managerial Ownership*LBO Type Dummy", "Undistributed Free Cash Flow", and "Tax Expenditures" are included in the following analyses.

The results reported subsequently are obtained using "EBITDA-Tax-Interests-Dividends" as the proxy for the prebuyout level of free cash flow.

Panel A Standard logistic regression on the likelihood of firms' going private via LMBOs and LIBOs over the sub period 1990-1999

\begin{tabular}{|c|c|c|c|c|c|}
\hline & & Model 1 & Model 2 & Model 3 & Model 4 \\
\hline \multirow[t]{3}{*}{ Undistributed Free Cash Flow } & Beta & & 0.02 & 0.02 & 0.02 \\
\hline & $\operatorname{Exp}(B)$ & & 1.02 & 1.02 & 1.02 \\
\hline & Sig. & & $0.01 * * *$ & $0.04 * *$ & $0.05^{* *}$ \\
\hline \multirow[t]{3}{*}{$\mathrm{P} / \mathrm{E}$} & Beta & -0.01 & -0.01 & -0.01 & \\
\hline & $\operatorname{Exp}(B)$ & 0.99 & 0.99 & 0.99 & \\
\hline & Sig. & 0.25 & 0.19 & 0.16 & \\
\hline \multirow[t]{3}{*}{ Volatility of Cash Flow } & Beta & & 0.00 & & \\
\hline & $\operatorname{Exp}(B)$ & & 1.00 & & \\
\hline & Sig. & & 0.71 & & \\
\hline Investment Opportunities & Beta & 0.01 & & & 0.01 \\
\hline \multirow[t]{2}{*}{ (Tobin's Q) } & $\operatorname{Exp}(B)$ & 1.01 & & & 1.01 \\
\hline & Sig. & 0.90 & & & 0.91 \\
\hline \multirow[t]{3}{*}{ Tax Expenditures } & Beta & & & & 0.07 \\
\hline & $\operatorname{Exp}(B)$ & & & & 1.07 \\
\hline & Sig. & & & & 0.11 \\
\hline Managerial Ownership* LBO & Beta & & & -0.01 & \\
\hline \multirow[t]{2}{*}{ Type Dummy } & $\operatorname{Exp}(B)$ & & & 0.99 & \\
\hline & Sig. & & & 0.43 & \\
\hline \multirow[t]{3}{*}{ Constant } & Beta & 0.11 & -0.07 & 0.07 & -0.46 \\
\hline & $\operatorname{Exp}(B)$ & 1.11 & 0.93 & 1.08 & 0.63 \\
\hline & Sig. & 0.68 & 0.79 & 0.77 & 0.13 \\
\hline $\mathrm{N}$ & & 109 & 102 & 96 & 94 \\
\hline 2-log likelihood & & 149.50 & 127.71 & 123.90 & 118.18 \\
\hline Cox \& Shell R Square & & 0.01 & 0.13 & 0.09 & 0.12 \\
\hline Nagelkerke R Square & & 0.02 & 0.17 & 0.12 & 0.16 \\
\hline Chi-square & & 1.59 & 13.69 & 9.02 & 12.14 \\
\hline $\mathrm{df}$ & & 2.00 & 3.00 & 3.00 & 3.00 \\
\hline Sig. & & 0.45 & $0.00 * * *$ & $0.03 * *$ & $0.01 * * *$ \\
\hline
\end{tabular}


Panel B Conditional logistic regression on the likelihood of firms' going private via LMBOs and LIBOs over the sub period 1990-1999

\begin{tabular}{|c|c|c|c|c|c|}
\hline & & Model 1 & Model 2 & Model 3 & Model 4 \\
\hline \multirow[t]{3}{*}{ Undistributed Free Cash Flow } & Beta & & 0.05 & 0.05 & 0.04 \\
\hline & $\operatorname{Exp}(B)$ & & 1.05 & 1.06 & 1.04 \\
\hline & Sig. & & $0.01^{* * * *}$ & $0.03^{* *}$ & $0.04^{* *}$ \\
\hline \multirow[t]{3}{*}{$\mathrm{P} / \mathrm{E}$} & Beta & -0.02 & -0.03 & -0.03 & \\
\hline & $\operatorname{Exp}(B)$ & 0.98 & 0.97 & 0.97 & \\
\hline & Sig. & $0.06^{*}$ & $0.10^{*}$ & $0.06^{*}$ & \\
\hline \multirow{3}{*}{ Volatility of Cash Flow } & Beta & & -0.08 & & \\
\hline & $\operatorname{Exp}(B)$ & & 0.93 & & \\
\hline & Sig. & & 0.20 & & \\
\hline \multirow{3}{*}{$\begin{array}{l}\text { Investment Opportunities } \\
\text { (Tobin's Q) }\end{array}$} & Beta & -0.09 & & & 0.04 \\
\hline & $\operatorname{Exp}(B)$ & 0.92 & & & 1.04 \\
\hline & Sig. & 0.26 & & & 0.64 \\
\hline \multirow[t]{3}{*}{ Tax Expenditures } & Beta & & & & 0.06 \\
\hline & $\operatorname{Exp}(B)$ & & & & 1.06 \\
\hline & Sig. & & & & 0.29 \\
\hline Managerial Ownership* LBO & Beta & & & 0.00 & \\
\hline \multirow[t]{2}{*}{ Type Dummy } & $\operatorname{Exp}(B)$ & & & 1.00 & \\
\hline & Sig. & & & 0.89 & \\
\hline $\mathrm{N}$ & & 41 & 34 & 31 & 32 \\
\hline 2-log likelihood & & 51.59 & 29.256 & 30.825 & 35.527 \\
\hline Cox \& Shell R Square & & 0.12 & .409 & 0.32 & 0.24 \\
\hline McFadden R Square & & 0.09 & 0.379 & 0.28 & 0.20 \\
\hline Chi-square & & 5.24 & 17.88 & 12.15 & 8.83 \\
\hline & & & 3 & & \\
\hline Sig. & & $0.07 *$ & $0.00^{* * * *}$ & $0.01 * * *$ & $0.03 * *$ \\
\hline
\end{tabular}

Note: $*, * *$, and $* * *$ indicates statistical significance at $10 \%, 5 \%$, and $1 \%$ levels respectively. 
By comparing the results of the two methods for explanatory factors of the likelihood of firms' going private via LIBOs and LMBOs, this study finds the following important differences. 1) Compared to conditional logistic regression, standard logic regression fails to identify $\mathrm{P} / \mathrm{E}$ as a determinant of the likelihood of firms' undertaking LBOs in the 1990s. However, conditional logistic regression models (i.e. Model 1, 2 \&3) consistently show the negatively significant coefficient on P/E. Thus, using standard logistic regression in this case can lead researchers wrongly reject the market undervaluation hypothesis. 2) For the free cash flow variable identified by standard logistic regression as a significant factor explaining the likelihood of firms' going private via LBOs in the 1990s, standard logistic regression generates smaller p-value in each model. The estimated statistical significances of the free cash flow variable change from 0.03 to 0.04 (in model 4) and from 0.04 to 0.05 (in model 5). 3) There are changes in signs on three variables between the two statistical methods. These three variables are "volatility of cash flow", "investment opportunities (Tobin's Q)", and "managerial ownership* LBO type dummy". Thus, researchers can be misled by standard logistic regression about the affects of these variables on the likelihood of firms' undertaking private. Overall, the above results show that there are significant differences in the results between the two statistical methods. These differences have great impacts on the null hypothesis testing in this particular example. The above results also confirm that conditional logistic regression is more powerful in distinguishing the difference in firm-specific variables of LBOs from non-LBOs. 


\section{CHAPTER 7: SUMMARY AND CONCLUSIONS}

This chapter begins with a summary of the major findings for the three subtopics of this study. The conclusions for each of the three working theories of this study are summarized at the end of this chapter. Specific contributions and benefits of this study are discussed in the following chapter.

The main objective of this research is to investigate changing value sources and motivations of LIBOs and LMBOs over the period 1985-2005 through examining the following three subtopics: 1) Changes in LBO deal characteristics over time; 2) Factors explaining LIBO and LMBO premiums; and 3) Factors explaining the likelihood of firms' going private via LIBOs and LMBOs. It is also the intent of this study to test the three key working theories in LBO literature, namely the free cash flow hypothesis, the overheated market hypothesis, and the heterogeneity hypothesis, on both LIBOs and LMBOs.

With respect to changes in LBO deal characteristics over the period 1985-2005 (Subtopic 1), this study has several interesting findings: 1) LMBO deal characteristics had significantly changed over the period 1985-2005. LMBO overall deal characteristics over the sub period 2000-2005 are greatly different from those in the 1990s, but they are similar to those in the late 1980s. 2) LIBO deal characteristics have remained unchanged over time, except that deal size of LIBOs over the sub period 2000-2005 is significantly larger than before. 3) The differences in deal characteristics between LIBOs and LMBOs are time specific. There are no significant differences in the overall deal characteristics 
between LIBOs and LMBOs in the 1990s. In contrast, LMBO targets are found to be in worse financial conditions than LIBOs over the sub period 2000-2005. Surprisingly, higher premiums are paid for these LMBOs with less attractive financial prospects. Overall, these findings imply that the LMBO market over the sub period 2000-2005 was overheated.

With regard to explanatory factors of LBO premiums (Subtopic 2), this study identifies different firm-specific characteristics that can explain LBO premiums over the three different sub periods. This finding implies that the value sources of LBOs had greatly changed over the period 1985-2005.

1) Over the sub period $1985-1989$, this study finds that higher premiums were paid for poorly-performing LMBO targets. This irrational investor behavior can be attributed to the overheated LBO market conditions in the late 1980s.

2) Over the sub period $1990-1999$, this study finds that higher premiums were paid for the LBO target firms with higher levels of undistributed free cash flows, less investment opportunities, and higher dividend payout ratios. These results imply that the value created throughout LIBO and LMBO transactions in the 1990s is mainly from the reduction of agency costs (representing the free cash flow hypothesis).

3) Over the sub period 2000-2005 (Subtopic 3), the results of this study suggest that LMBO deal prices during this sub period were mainly pushed up by greater availability of debt financing. Additionally, instead of finding the free cash flow variable to be significant for both LIBOs and LMBOs, this study identifies the interaction effects of LBO type dummy with the free cash flow variable. This finding implies that the free cash 
flow hypothesis holds only for LIBOs over the sub period 2000-2005. These findings on LMBOs are consistent with the overheated market hypothesis.

In terms of explanatory factors of the likelihood of firms' undertaking LBOs (Subtopic 3), the results of this study suggest that the motivations for firms' going private via LBOs had greatly changed over the period 1985-2005.

1) Over the sub period $1985-1989$, this study finds neither the free cash flow variable nor the tax expenditures an incentive for firms to undertake LMBOs. This finding implies that fundamental financial prospects of the LMBO target firms in the late 1980s do not justify the incentives of LMBOs in the late 1980s.

2) Over the sub period 1990-1999, the findings of this study on the pre-buyout free cash flow, tax expenditures, and volatility of cash flow provide support for the free cash flow hypothesis. In addition, this study finds that firms with lower P/E ratios are more likely to undertake LBOs in the 1990s. This finding suggests that market undervaluation of LBO targets is also one of the incentives for firms' going private via LBOs in the 1990s. Consistent with the findings in the previous chapters, LMBOs are not found to have different motivations than LIBOs in the 1990s.

3) Over the sub period 2000-2005, this study finds that firms with higher levels of prebuyout managerial ownership are more likely to undertake LMBOs. In contrast, firms with lower levels of pre-buyout managerial ownership are more likely to go private via LIBOs. These findings are similar to Halpern et al (1999)'s conclusions and they support the heterogeneity hypothesis. This study further finds that the LMBO populations over the sub period 2000-2005 were heterogeneous in managerial ownership. The results 
imply that LMBO firms with higher levels of pre-buyout managerial ownership have different motivations than LMBO firms with lower levels of pre-buyout managerial ownership. LMBO firms with higher levels of pre-buyout managerial ownership went private because of the free cash flow explanation. However, for firms with lower levels of pre-buyout managerial ownership, their motivations of undertaking LMBOs can not be explained by the free cash flow hypothesis.

When combining the findings on the above three research subtopics together, this study has the following conclusions.

First, the findings on the above three subtopics all imply that the LMBO market was overheated in the sub period 2000-2005. An important cause of the overheated LBO market conditions may be that there was availability of too much debt financing. Interestingly, the overheated LMBO market conditions over the sub period 2000-2005 only greatly affected the value sources and incentives of LMBOs.

Second, due to the impacts of the overheated market conditions during 2000-2005, the results for both the sources of value created throughout LBOs and motivations behind LBOs are period specific and sample dependent. For LIBOs, the value sources/motivations are consistently from the free cash flow explanation. However, for LMBOs, fundamental financial prospects of target firms do not justify the premiums and movations of their undertaking LMBOs in the overheated LBO market. 
Third, in terms of the three key working theories of this study, this study finds that the applicability of both the free cash flow hypothesis and the heterogeneity hypothesis is affected by the overheated LBO market conditions. Due to the changing buyout market conditions over time, the conclusions for the three key working theories are also period and sample specific (See Table 1.1 for the conclusions for the three key working theories). As for the implications of the major findings of this study for the three key working theories, see Table 7.1 for a summary. 


\section{Table 7.1 Summary of Implications of the Major Findings for the Three Key Working Theories of This Study}

\begin{tabular}{|c|c|c|}
\hline $\begin{array}{l}\text { Key } \\
\text { Working } \\
\text { Theories of } \\
\text { This Study }\end{array}$ & $\begin{array}{l}\text { Conclusions for } \\
\text { The Key Working } \\
\text { Theories } \\
\text { Hypotheses }\end{array}$ & Major Findings \\
\hline \multirow[t]{4}{*}{$\begin{array}{l}\text { The } \\
\text { overheated } \\
\text { market } \\
\text { hypothesis }\end{array}$} & \multirow[t]{4}{*}{$\begin{array}{l}\text { The LBO market } \\
\text { was overheated } \\
\text { over the sub } \\
\text { period } 2000-2005\end{array}$} & $\begin{array}{l}\text { There are no differences found in the key deal characteristics } \\
\text { variables of LMBOs between over the sub period 1985-1989 and over } \\
\text { the sub period 2000-2005. }\end{array}$ \\
\hline & & $\begin{array}{l}\text { The deal characteristics of LIBOs and LMBOs are different only over } \\
\text { the sub period } 2000-2005 \text { and LMBOs during this sub period were in } \\
\text { worse financial conditions than LIBOs. }\end{array}$ \\
\hline & & $\begin{array}{l}\text { A significantly positive relation is found between the assumed } \\
\text { liability/transaction value and LMBO premiums over the sub period } \\
2000-2005 \text {. }\end{array}$ \\
\hline & & $\begin{array}{l}\text { LMBO populations over the sub period } 2000-2005 \text { are heterogeneous } \\
\text { in managerial ownership: firms with higher levels of pre-buyout } \\
\text { managerial ownership went private because of the free cash flow } \\
\text { explanation, while firms with higher levels of pre-buyout managerial } \\
\text { ownership went private because of the overheated market hypothesis. }\end{array}$ \\
\hline \multirow[t]{2}{*}{$\begin{array}{l}\text { The } \\
\text { heterogeneity } \\
\text { hypothesis }\end{array}$} & \multirow[t]{2}{*}{$\begin{array}{l}\text { The heterogeneity } \\
\text { hypothesis holds } \\
\text { for LBOs over the } \\
\text { sub period 2000- } \\
2005\end{array}$} & $\begin{array}{l}\text { There are interaction terms (i.e. an interaction of LBO type dummy } \\
\text { variable with the free cash flow variable) found that can explain both } \\
\text { the LBO premiums and the likelihood of firms' going private via } \\
\text { LBOs over the sub period } 2000-2005 \text {. }\end{array}$ \\
\hline & & $\begin{array}{l}\text { There are significant differences in overall deal characteristics } \\
\text { between LIBOs and LMBOs over the sub period } 2000-2005 \text {. }\end{array}$ \\
\hline \multirow[t]{4}{*}{$\begin{array}{l}\text { The free cash } \\
\text { flow } \\
\text { hypothesis }\end{array}$} & \multirow{2}{*}{$\begin{array}{l}\text { The free cash } \\
\text { flow hypothesis } \\
\text { holds for LBOs } \\
\text { over the sub } \\
\text { period } 1990-1999\end{array}$} & $\begin{array}{l}\text { Over the sub period 1990-1999, higher premiums are paid for the } \\
\text { LBO target firms with 1) higher levels of undistributed free cash flow; } \\
\text { 2) less investment opportunities; 3) higher dividend payout ratio. }\end{array}$ \\
\hline & & $\begin{array}{l}\text { Over the sub period } 1990-1999 \text {, firms with higher levels of } \\
\text { undistributed free cash flow, more tax expenditures, and less volatility } \\
\text { of cash flow are more likely to go private via LBOs. }\end{array}$ \\
\hline & \multirow{2}{*}{$\begin{array}{l}\text { The free cash } \\
\text { flow hypothesis } \\
\text { holds for LIBOs } \\
\text { over the sub } \\
\text { period } 2000-2005\end{array}$} & $\begin{array}{l}\text { Over the sub period } 2000-2005 \text {, higher premiums are paid for the } \\
\text { LIBO target firms with higher levels of undistributed free cash flow } \\
\text { and less investment opportunities. }\end{array}$ \\
\hline & & $\begin{array}{l}\text { Over the sub period } 2000-2005 \text {, firms with higher levels of } \\
\text { undistributed free cash flow, less investment opportunities, and less } \\
\text { volatility of cash flow are more likely to undertake LIBOs. }\end{array}$ \\
\hline
\end{tabular}




\section{CHAPTER 8: CONTRIBUTIONS, LIMITATIONS, AND SUGGESTIONS FOR FUTURE RESEARCH}

This chapter outlines major contributions, limitations and suggestions for future research of this study.

\subsection{Major Contributions of This Study}

This study achieves the following major contributions.

This is the first study that places LMBO and LIBO research within a significantly longer and more recent period, during which time the LBO market in the U.S. has changed. ${ }^{51}$ This empirical study is also the first one in LBO literature that provides strong evidence for the conclusion that LBO market, especially LMBO market, has become overheated in recent years. Furthermore, this study identifies the impacts of the overheated LBO market conditions on the value sources and motivations of LMBOs. ${ }^{52}$

Compared to the previous literature, this study makes an important improvement on unit of analysis. The previous studies not only adopt inconsistent definitions of LBOs but also mix the insider-led LBO with the outsider-led LBO as the unit of analysis (See Appendix C for details). In contrast, this study examines LIBOs and LMBOs separately based on clearer definitions of LIBOs and LMBOs. Moreover, this study finds different deal

\footnotetext{
${ }^{51}$ Note that there are a very limited number of existing studies on U.S. LBOs and they all focus on the U.S. LBOs in the 1980s.

${ }^{52}$ Unfortunately, most of the previous studies based on LBOs in the 1980s do not distinguish the LBOs completed in the early 1980s from those in late 1980s (when the LBO market was overheated). The time-specific results of this study indicate that their ignorance of the overheated market conditions in the late 1980s may affect the accuracy of their conclusions on the free cash flow hypothesis or the heterogeneity hypothesis.
} 
characteristics, value sources, and motivations between LIBOs and LMBOs when the LBO market was overheated. This implies that the LBO populations in the 1980s are wrongly considered as homogeneous by the previous research.

Furthermore, this study further extends Halpern et al (1999)'s idea of the heterogeneity hypothesis and the results of this study shed additional light on this hypothesis. This study considers the heterogeneity of LBOs in their initiators (LIBOs vs LMBOs). This study not only identifies the differences in LBO deal characteristics between LIBOs and LMBOs, but also explores the possibility of the heterogeneity of LMBOs over the sub period 1985-1989 and 2000-2005. The results of this study imply that the heterogeneity of LBOs in managerial ownership identified by Halpern et al (1999) may only partially reflect the underlying logic of differences between LIBOs and LMBOs.

In addition, the results of this study for the three key working theories are robust. First, this study adopts two different proxies to measure pre-buyout free cash flow and three proxies to measure LBO premiums. The results of this study for the free cash flow hypothesis are robust across different proxies. Thus they shed light on the controversy about the free cash flow hypothesis in LBO literature. Second, this study examines not only the explanatory factors of LBO premiums but also the factors explaining the likelihood of firms' undertaking LBOs. The findings for these two subtopics provide the similar implications for the three key working theories of this study. Thus, the conclusions of this study for the three key working theories are robust. 
Finally, the contribution of this study is also significant in the research area of the explanatory factors of the likelihood of firms' going private via LBOs. Unlike the previous literature that effectively ignores matching sample challenges, this study is the first that adopts the appropriate statistical method to process the 1-1 matched case-control sampling design. Moreover, this study identifies the advantage of conditional logistic regression over standard logic regression: Conditional logistic regression is found to be more powerful than standard logic regression in identifying the explanatory factors of the likelihood of firms' going private via LBOs.

\subsection{Implications for Market Participants and Researchers}

There are following key implications of this research.

First, the conclusion that the LBO market has become overheated in recent years undoubtedly provides great implications for market participants and policy markers. Particularly, the results of this study suggest that the overheated LBO market over the sub period 2000-2005 is mainly fuelled by availability of too much debt financing and a relaxation of lenders' terms and conditions on debt financing in a low interest rate environment (See Appendix for details). According to the overheated market hypothesis, when there is too much money chasing a limited number of good deals then the market will overheat, leading to an increase in the number of failures (Kaplan \& Stein, 1993). The above conclusions are consistent with the comments some practitioners have made recently: The chief executive of the private equity firm TA Associates, Kevin Landry said "Borrowed money is the real fuel driving an overheated market. I think of this as a debt 
bubble, not a private equity bubble." ${ }^{53}$ Michael, Tennenbaum of Tennenbaum Capital Partners, a $\$ 7$ billion investment firm specializing in distressed debt said when he asked private equity firms why they are paying these prices, they said, "Because we can finance them." ${ }^{54}$ Thus, ready access to a seemingly bottomless source of funds encouraged private equity firms to make ever bigger and bolder bids. However, as subprime mortgage crisis continues spreading, the recent rising defaults in the subprime mortgage market and the related growing credit crunch started having great impacts on the U.S. LBO market. The LBO market is now facing severe liquidity, serious refinancing problems, and severe credit problems.

In addition to the deterioration in the leveraged debt market, the recent U.S. economic market conditions can further negatively impact the LBO market, as economy in the U.S. is going into recession. For the current LBO deals, the problem with structuring large deals in bad economy is that large deals may have trouble finding lenders on terms recently available, thus having risk of not being completed. For the firms that have already gone private via LBOs, if the economy slows further, or companies hit cyclical downturns, they may find themselves struggling to meet their debt obligations.

Generally, the results of this study suggest that for market participants, more time be taken to assess a target firm's profitability when managements plan to take their firms private via LMBOs. Although some argue that times have changed and value sources of

\footnotetext{
${ }_{53}^{53}$ http://www.boston.com/business/articles/2007/05/01/private_equity_debt_bubble

${ }^{54}$ http://money.cnn.com/2007/08/06/markets/privateequitybubble.fortune/index.htm
} 
LBOs should have greatly changed as well, the results of this study show that the traditional incentives of LBOs (i.e. reduction of agency costs) can still be seen in most of the LBOs when buyout market was not overheated. In the recent overheated LMBO market, especial caution needs to be exercised by the LMBO firms in which managements have lower levels of managerial ownership. It is because that the free cash flow hypothesis cannot explain the incentives of this kind of firms' undertaking LBOs. Instead, the results of this study imply that with the help of greater availability of debt financing in the post-2000 period, managements of this kind of firms were able to take their firms private even though the firms were not in good financial conditions. According to Halpern et al (1999), the incentives of these firms' going private may be to avoid potential takeover pressure for their "empire building" ambitions. For LIBOs, institutions these days cannot afford to buy huge companies by themselves, so they choose to team up buying larger targets while sharing the risk. Even though the results of this study show that LBO market cycle did not affect the value sources and motivations of LIBOs over the sub period 2000-2005, institutions need to weight the downsides of large LIBO deals especially after credit crunch began in debt market in a weaker economy.

For researchers, this study finds that LMBO deal characteristics have greatly changed over time, thus it is likely that the insights of previous literature based on LBOs in the 1980s can not be generalized across recent years. Moreover, this study finds that the applicability of the free cash flow hypothesis to LBOs is period specific. Thus, it is important for researchers to take into account boom-bust cycle in LBO market when 
examining the free cash flow hypothesis. Also, researchers should be cautious comparing the results based on LBOs over different study periods.

The results of this study imply that LIBOs have different deal characteristics and value sources than LMBOs and the differences between LIBOs and LMBOs are period specific. LBO populations were heterogeneous in the initiators only over the sub period 2000-2005 when the LBO market was overheated. Thus, researchers need to not only take into account buyout market conditions but also avoid mixing LIBOs with LMBOs when examining value sources of LBOs.

\subsection{Limitations}

There are following limitations of this research.

First, the explanatory variables of the LBO premiums and the likelihood of firms' going private via LBOs examined in this study mainly represent the financial performances of LBO target firms and ownership characteristics. As financial and economic environment for LBO market has changed significantly in recent years, some researchers argue that private equity investors' role has been transformed from financial buyers to strategic buyers (See Appendix A for details). Unfortunately, the variables examined in this study do not reflect these potential strategic incentives to initiate LBOs.

Second, value sources and incentives of LMBOs in recent years need to be further explored. For example, this study finds that the free cash flow hypothesis does not hold 
for LMBOs over the sub period 2000-2005. In this study, this finding is attributed to the overheated market conditions and the heterogeneity in LMBOs over the sub period 20002005. However, more plausible explanations such as potential strategic incentives still need to be explored.

Third, this research is focused on the LBOs in the U.S. However, as there are more and more cross-country LBO deals in this globalization era, the LBO markets outside the U.S. in the post-2000 period and their impacts on the recent U.S. LBO market needs to be further explored.

\subsection{Suggestions for Future Research}

The limitations discussed in the previous section would lead to future research.

First, Smit and Maeseneire (2005) argue that valuable future research may be provided by empirical studies of LBOs that explicitly examine value creation given the target's and private investor's unique resources, and that concentrate more on the 'leveraging core competencies' value sources rather than on the widely documented traditional sources. Thus, variables need to be examined from strategic perspective in future LBO research.

Second, more plausible value sources of LMBOs need to be explored in terms of the explanatory factors of the premiums in LMBOs and the likelihood of firms' going private via LMBOs. To further explore the overheated LBO market hypothesis over the sub

period 2000-2005, more variables such as debt components of assumed liability and post- 
buyout operating performances of LBO firms need to be investigated

Third, LBOs have become very popular in the U.K. in recent years, but the studies on U.K. LBOs usually compare their findings of U.K. LBOs in recent years with the conclusions of value sources based on U.S. LBOs in the 1980s. The results of this study have clearly indicated that the results of previous literature on U.S. LBO could not be applied to the U.S. LBOs in recent years. Therefore, more direct comparisons of LBO deals across countries at the same time periods need to be performed. Moreover, more research on value sources of the LBOs outside the U.S. needs to be explored. 


\section{REFERENCES}

Agresti, A. (1996). An introduction to categorical data analysis. John Wiley and Sons.

Allen, J. R. (1996). LBOs-The evolution of financial structures and strategies. Journal of Applied Corporate Finance 8, 18-29.

Amemiya, T. (1985). Advanced econometrics. Blackwell, Oxford.

Bezter, A., Andres, C., \& Hoffman, M. (2004). Going private via LBO - shareholder gains in the european market. EFMA 2004 Basel Meetings Paper.

Asquith, P., \& Wizman, T. A. (1990). Event risk, covenants, and bondholder returns in leveraged buyouts. Journal of Financial Economics, 27(1), 195-213.

Bae, S. C., \& Hoje, J. (2002). Consolidating corporate control: Divisional versus wholecompany leveraged buyouts. Journal of Financial Research, 25(2), 247-262.

Barber, B. M., \& Lyon, J. D. (1997). Detecting long-run abnormal stock returns: The empirical power and specification of test statistics. Journal of Financial Economics, 43 (3), 341-372.

Beaver, W. H. (1966). Financial ratios as predictors of failure. Journal of Accounting Research, 4(3), 71-111.

Berle, A. A., \& Means, G. C. (1932). The modern corporation and private property. New York: Macmillan.

Bernanke, B. S., \& Campbell, J. Y. (1990). U.S. corporate leverage: Developments in 1987 and 1988. Brookings Papers on Economic Activity, Issue 1, 255-286.

Betzer, A. (2006). Does Jensen's free cash flow hypothesis explain European LBOs today? Available at SSRN: http://ssrn.com/abstract $=875363$.

Black, F. B. (1986). Noise. Journal of Finance, 41(3), 529-543.

Bradley, M., Desai, A., \& E. Han Kim, A. (1988) Synergistic gains from corporate acquisitions and their division between the stockholders of target and acquiring firms. Journal of Financial Economics, 21(1), 3-40.

Brainard, W. C., \& Tobin, J. (1968). Pitfalls in financial model building. American Economic Review Papers and Proceedings, 58(2), 99-122.

Breslow, N. E. (1996). Statistics in epidemiology: The case-control study. Journal of the American Statistical Association, 91(433), 14-28. 
Bruton, G. D., Keels, J. K., \& Scifres, E. L. (2002). Corporate restructuring and performance: An agency perspective on the complete buyout cycle. Journal of Business Research, 55(9), 709-724.

Bugeja, M., \& Walter, T. (1995). An empirical analysis of some determinants of the target shareholder premium in takeovers. Accounting \& Finance, 35(2), 33-60.

Byrd, J. W., \& Hickman, K. A. (1992). Do outside directors monitor managers? Journal of Financial Economics, 32(2), 195-221.

Carow, K. A. \& Roden, D. M. (1998). Determinants of the stock price reaction to leveraged buyouts. Journal of Economics \& Finance, 22(1), 49-59.

Carson, J. M., \& Hoyt, R. E. (2003). An empirical examination of sample selection methods in the context of life insurer financial distress. Journal of Insurance Regulation, 22(2), 70-71.

Chatfield, R. E., \& Newbould, G. D. (1996). Leveraged buyouts: Implications for U.S. treasury tax receipts. Quarterly Journal of Business \& Economics, 35(1), 51-66.

Chevalier, J. A. (1995). Do LBO supermarkets charge more? An empirical analysis of the effects of LBOs on supermarket pricing. Journal of Finance, 50 (4), 1095-1112.

Cotter, J. F. \& Peck, S. W. (2001). The structure of debt and active equity investors: The case of the buyout specialist. Journal of Financial Economics, 59(1), 101-147.

Christinat, J. (2003). Deck is stacked for uptick in Canadian LBOs, (cover story), Buyouts, 16(12), 1-4.

Cram, D. P., Karan, V., \& Stuart, I. (2007). Three Threats to validity of choice-based and matched sample studies in accounting research. http://papers.ssrn.com/sol3/papers.cfm?abstract id=955031

DeAngelo, H., DeAngelo, L., \& Rice, E. M. (1984). Going private: minority freezeouts and stockholder wealth. Journal of Law \& Economics, 27(2), 367-401.

DeAngelo, H. \& DeAngelo, L. (1985). Management Buyouts of Publicly Traded Corporations. Financial Analysts Journal, 43(3), 38-49.

De Long, J. B., Shleifer, A., Summers, L. H., \& Waldmann, R. J. (1990). Noise trader risk in financial markets. Journal of Political Economy, 98(4), 703-738.

Denis, D. J. (1992). Corporate investment decisions and corporate control: Evidence from going-private transactions. Financial Management (Financial Management Association), 21(3), 80-94. 
Diamond, D. W. (1993). Seniority and maturity of debt contracts. Journal of Financial Economics, 33(3), 341-368.

Dodd, P., \& Ruback, R. (1977). Tender offers and stockholder returns. Journal of Financial Economics, 5(3), 351-373.

Dong, M., Hirshleifer, D., Richardson, S., \& Teoh, S. H. (2006). Does investor misvaluation drive the takeover market? Journal of Finance, 61(2), 725-762.

Eastwood, J. C. (1998). Divestments and financial distress in leveraged buyouts. Journal of Banking \& Finance, 22(2), 129-159.

Easterwood, J. C., Seth, A., \& Singer, R. F. (1989). The impact of leveraged buyouts on strategic direction. California Management Review, 32(1), 30-43.

Eddey, P. H., Lee, K. W., \& Taylor, S. L. (1996). What motivates going private? An analysis of Australian firms. Accounting \& Finance, 36(1), 31-50.

Elgers, P. T., \& Clark, J. J. (1980). Merger types and shareholder returns: additional evidence. Financial Management (Financial Management Association), 9(2), 66-72.

Epplin, M. P., \& Pourjalali, H. (1997). Industry concentration and cyclicality of cash flows in Leveraged Buyouts. American Business Review, 15(1), 15-25.

Fama, E. F., \& French, K. R. (1992). The cross-section of expected stock returns. Journal of Finance, 47(2), 427-465.

Fazzari, S. M., Hubbard, R. G., \& Petersen, B. C. (1988). Financing constraints and corporate investment. Brookings Papers on Economic Activity, O(1), 141-195.

Fox, I., \& Marcus, A. (1992). The causes and consequences of leveraged management buyouts. Academy of Management Review, 17(1), 62-85.

Garfinkel, M. R. (1989). The causes and consequences of leveraged buyouts. The Federal Reserve Bank of St. Louis Review, 89(9), 23-34.

Garvey, G. T. (1992). Leveraging the underinvestment problem: how high debt and management shareholdings solve the agency costs of free cash flow. Jourrzol of Firrnrzciol Resrorrlr, 40, 149-166.

Gomme, P. (2005). Why policymakers might care about stock market bubbles (cover story). Economic Commentary, 1-3.

Gompers, P. \& Lerner, J. (2000). Money chasing deals? The impact of fund inflows on private equity valuations. Journal of Financial Economics, 55(2), 281-325. 
Green, S. (1992). The impact of ownership and capital structure on managerial motivation and strategy in management buyouts: a cultural analysis. Journal of Management Studies, 513-535.

Gupta, A. \& Rosenthal, L. (1991). Ownership structure, leverage, and firm value: The case of leveraged recapitalizations. Financial Management (Financial Management Association), 20(3), 69-83.

Halpern, P., Kieschnick, R., \& Rotenberg, W. (1998). The Influence of Target Managerial Shareholdings on Acquisitions of Corporations. CMI Capital Market Institute. http://www.rotman.utoronto.ca/cmi/papers/paper3-1.htm.

Halpern, P., Kieschnick, R., \& Rotenberg, W. (1999). On the heterogeneity of leveraged going private transactions, Review of Financial Studies, 12(2).

Hite, G. L., \& Vetsuypens, M. R. (1989). Management buyouts of divisions and shareholder wealth. Journal of Finance, 44(4), 953-970.

Holthausen, R. W., \& Larcker, D. F. (1996). The financial performance of reverse leveraged buyouts. Journal of Financial Economics, 42(3), 293-332.

Hosmer, D. W., \& Lemeshow, S. (1989). Applied logistic regression. New York: Wiley.

Jandik, T., \& Makhija, A. K. (2005). Leverage and the complexity of takeovers. Financial Review, 40(1), 95-112.

Jensen, M. C. (1986). Agency costs of free cash flow, corporate finance, and takeovers. American Economic Review, 76(2), 323-329.

Jensen, M. C. (1988). Takeovers: Their causes and consequences. Journal of Economic Perspectives, 2(1), 21-48.

Jensen, M. C., \& Meckling, W. H. (1976). Theory of the firm: managerial behavior, agency costs and ownership structure. Journal of Financial Economics, 3(4), 305-360.

Jin, L. \& Wang, F. (2002). Leveraged buyouts: inception, evolution, and future trends. Perspectives, 3(6), http://www.oycf.org/.

Jung, K., Kim, Y., \& Stulz, R. M. (1996). Timing, investment opportunities, managerial discretion, and the security issue decision. Journal of Financial Economics, 42(2), 159185.

Kaplan, S. (1989). The effects of management buyouts on operating performance and value. Journal of Financial Economics, 24(2), 217-254. 
Kaplan, S. (1989). Management buyouts: evidence on taxes as a source of value. Journal of Finance, 44(3), 611-632.

Kaplan, S. N. (1991). The staying power of leveraged buyouts. Journal of Financial Economics, 29(2), 287-314.

Kaplan, S. N., \& Stein, J. C. (1990). How risky is the debt in highly leveraged transactions? Journal of Financial Economics, 27(1), 215-245.

Kaplan, S. N., \& Stein, J. C. (1993). The evolution of pricing and financial structure in the 1980s. Quarterly Journal of Economics, 108(2), 313-356.

Kieschnick, R. L. (1998). Free cash flow and stockholder gains in going private transactions revisited. Journal of Business Finance \& Accounting, 25(1/2), 187-202.

Kosedag, A., \& Lane, W. R. (2002) Is it free cash flow, tax savings, or neither? An empirical confirmation of two leading going-private explanations: the case of ReLBOs. Journal of Business Finance \& Accounting, 29(1/2), 257-271.

Kosedag, A., \& Michayluk, D. (2004). Repeated LBOs: The case of multiple LBO transactions. Quarterly Journal of Business \& Economics, 43(1/2), 111-122.

Kothari, S., \& Warner, J. (1997). Measuring long-horizon security price performance. Journal of Financial Economics, 43(3), 301-339.

Kim, K., Henderson, Jr. \& Glenn, V. (1993). Examination of Tobin's q for takeover firms. Quarterly Journal of Business \& Economics, 32(1), 3-27

Landsman, W. R., \& Shackelford, D. A. (1995). The lock-in effect of capital gains taxes: Evidence from the RJR Nabisco leveraged buyout. National Tax Journal, 48(2), 245-259.

Lee, C., Rosenstein, S. Rangan, N., \& Davidson W. N. (1992). Board composition and shareholder wealth: The case of management buyouts. Financial Management (Financial Management Association), 21(1), 58-72.

Lee, P. M., \& O'Neill, H. M. (2003). Ownership structures and R\&D investments of U.S. and Japanese firms: agency and stewardship perspectives. Academy of Management Journal, 46(2), 212-225.

Lehn, K., \& Poulsen, A. (1989). Contractual resolution of bondholder-stockholder conflicts in leverage buyouts. Journal of Law \& Economics, 34(2), 645-673.

Lehn, K., \& Poulsen, A. (1989). Free cash flow and stockholder gains in going private transactions. Journal of Finance, 44(3), 771-787. 
Lehn, K., Netter, J. \& Poulsen, A. (1990). Consolidating corporate control dual-class recapitalizations versus leveraged buyouts, Journal of Financial Economics, 27(2), 557580.

Lichtenberg, F. R., \& Siegel, D. (1990). The effects of leveraged buyouts on productivity and related aspects of firm behavior. Journal of Financial Economics, 27(1), 165-194.

Long, W. F. \& Ravenscraft, D. J. (1993). LBOs, debt and R\&D intensity. Strategic Management Journal, 14(4), 119-135.

Lowenstein, L. (1986). No more cozy management buyouts. Harvard Business Review, 64(1), 147-156.

Lyon, J. D., \& Barber, B. M. (1999). Improved methods for tests of long-run abnormal stock returns. Journal of Finance, 54(1), 65-101.

MacFadyen, K., \& Reinebach, A. (2004). Canadian buyout market emerges from the shadows. Venture Capital Journal, 44(5), 51-53.

Maddala, G. S. (1991). A perspective on the use of limited-dependent and qualitative variables models in accounting research. Accounting Review, 66(4), 788-807.

Madden, G. P., Marples, L. W., \& Chugh, L. C. (1990). A stock market evaluation of management buyouts. Journal of Business Finance \& Accounting, 17(3), 351-358.

Maksimovic, V., \& Titman, S. (1991). Financial policy and reputation for product quality, Review of Financial Studies, 4(1), 175-200.

Manski, C. F., \& McFadden, D. (1981). Alternative estimators and sample designs for discrete choice in structural analysis of discrete data with econometric applications. MIT Press, Cambridge, MA.

Manski, C. F., \& McFadden, D. (1981). Structural Analysis of Discrete Data with Econometric Applications. MIT Press, Cambridge, MA.

Marais, L., Schipper, K. \& Smith, A. (1989). Wealth effects of going private for senior securities. Journal of Financial Economics, 23(1), 155-191.

Maupin, R., Bidwell, C., \& Ortegren, A. (1984). An empirical investigation of the characteristics of publicly-quoted corporations which change to closely-held ownership through management buyouts. Journal of Business Finance \& Accounting, 11(4), 435450.

Mian, S., \& Rosenfeld, J. (1993). Takeover activity and the long-run performance of reverse leveraged buyouts. Financial Management, 22(4), 46-57. 
Moolgavkar, S., Lustbader, E., \& Venzon, D. J. (1985). Assessing the adequacy of the logistic regression model for matched case-control studies. Statistics in Medicine, 4, 425435.

Morck, R., Shleifer, A., \& Vishny, R. W. (1988). Management ownership and market valuation: an empirical analysis. Journal of Financial Economics, 20(1/2), 293-315.

Müller, H. M., \& Panunzi, F. (2004). Tender offers and leverage. Quarterly Journal of Economics, 119(4), 1217-1248.

Muscarella, C. J., \& Vetsuypens, M. R. (1990). Efficiency and organizational structure: A study of reverse LBOs. Journal of Finance, 45(5), 1389-1413.

Myers, S.C., \& Majluf, N.S. (1984). Corporate financing and investment decisions when firms have information that investors do not have. Journal of Financial Economics 13(2), 187-221.

Nathan, K. S., \& O'Keefe, T. B. (1989). The risk in takeover premiums: an exploratory study. Journal of Financial Economics, 23(1), 101-119.

Noronha, G., \& Yung, K. (1997). Reverse LBO underpricing: Information asymmetry or price support? Journal of Applied Business Research, 13(3), 67-78.

Ofek, E. (1994). Efficiency gains in unsuccessful management buyouts. Journal of Finance, 49(2), 637-654.

Opler, T. (1992). Operating performance in leveraged buyouts: Evidence from 19851989. Financial Management, 21(1), 27-34.

Opler, T., \& Titman, S. (1993). The determinants of leveraged buyout activity: Free cash flow vs. financial distress costs. Journal of Finance, 48(5), 1985-1999.

Palepu, K. G. (1990). Consequences of leveraged buyouts. Journal of Financial Economics, 27(1), 247-262.

Palepu, K. G. (1986). Predicting takeover targets. Journal of Accounting \& Economics, $8(1), 3-35$.

Phan, P. H., \& Hill, C. W. L. (1995). Organizational restructuring and economic performance in leveraged buyouts: An ex post study. Academy of Management Journal, 38(3), 704-739.

Prentice, R. L., \& Pyke, R. (1979). Logistic disease incidence models and case-control studies. Biometrika, 66(December), 403-11. 
Prentice, R. L. (1986). A case-cohort design for epidemiologic cohort studies and disease prevention trials. Biometrika, 73, 1-11.

Pregibon, D. (1981). Data analytic methods for matched case-control studies. Biometrics, $40,639-651$.

Roden, D. M., \& Lewellen, W. G. (1995). Corporate capital structure decisions: Evidence from leveraged buyouts. Financial Management, 24(2), 76-87.

Sahlman, W. A. (1990). The structure and governance of venture-capital organizations. Journal of Financial Economics, 27(2), 473-521.

Scott, A. J., \& Wild, C. J. (1986). Fitting logistic models under case-control or choice based sampling. J.R. Statist. Soc. B, 48, 170-182.

Scott, A. J., \& Wild, C. J. (2002). On the robustness of weighted methods for fitting models to case-control data. Journal of the Royal Statistical Society: Series B (Statistical Methodology), 64(2), 207-219.

Singh, H. (1990). Management buyouts: distinguishing characteristics and operating changes prior to public offfering. Strategic Management Journal, 11(4), 111-129.

Servaes, H. (1991). Tobin's Q and gains from takeovers. Journal of Finance, 46(1), 409419.

Servaes, H. (1994). Do takeover targets overinvest? Review of Financial Studies, 7(2), 253-277.

Smith, A. J. (1990). Corporate ownership structure and performance: The case of management buyouts. Journal of Financial Economics, 27(1), 143-164.

Smit, H. T. J., \& Maeseneire, W. de. (2005). The role of investor capabilities in public-toprivate transactions. Working paper.

Stancill, J. M. (1988). LBOs for smaller companies. Harvard Business Review, 66(1), 1823.

Stein, T. (2005). Canadian LBO market matures. Buyouts (cover story), 18(23), 24-26.

Stulz, R. M., Walkling, R. A., \& Song, M. H. (1990). The distribution of target ownership and the division of gains in successful takeovers. Journal of Finance, 45(3), 817-833.

Thompson, S. G. (1986). Modeling in matched case-control studies in epidemiology. The Statistician, 35, 237-244. 
Torabzadeh, K. M., \& Bertin, W. J. (1987). Leveraged buyouts and shareholder returns. Journal of Financial Research, 10(4), 313-319.

Travlos, N. J., \& Cornett, M. M. (1993). Going private buyouts and determinants of shareholders' returns. Journal of Accounting, Auditing \& Finance, 8(1), 1-25.

Treynor, J. L. (1993). The Value of Control. Financial Analysts Journal, 49(4), 6-9.

Weir, C., Laing, D., \& Wright, M. (2005). Incentive effects, monitoring mechanisms and the market for corporate control: An analysis of the factors affecting public to private transactions in the UK. Journal of Business Finance \& Accounting, 32(5/6), 909-943.

Williamson, O. E. (1988). Corporate finance and corporate governance. Journal of Finance, 43(3), 567-591.

Weston, J. F., \& Chen, Y. (1994). A tale of two eras. Business Economics, 29(1), 27-33.

Wright, M., Hoskisson, R. E., Busenitz, L. W., \& Dial, J. (2001). Finance and management buyouts: agency versus entrepreneurship perspectives. Venture Capital, $3(3), 239-261$.

Xiang, A. H., \& Langholz, B. (2003), Robust variance estimation for rare ratio parameter estimates from individually matched case-control data. Biometrika, 90(3), 741-746.

Yago, G., \& McCarthy, D. (2004). The U.S. Leveraged Loan Market: A primer. Milken Institute.

Zahra, S. A., \& Fescina, M. (1991). Will leveraged buyouts kill U.S. corporate research and development? Academy of Management Executive, 5(4), 7-21. 


\section{APPENDIX A: STRUCTURAL CHANGES IN FINANCIAL AND ECONOMIC ENVIRONMENT FOR LBO MARKET}

Drastic changes in financial and economic environment for LBO market in recent years have great effects on the way that LBOs are structured and the sources of value created through LBO transactions. For example, recent years have seen emergence of hedge funds, large pools of private equity capital, and aggressive lending practices of financial institutions in LBO market.

\section{1) Availability of LBO Loans}

Yago and McCarthy (2004) find that there is more debt available in recent years and financial institutions' lending actives have been more aggressive than before. The availability of more debt and aggressive lending practices may have changed LBO deal characteristics resulting in bigger and more complex LBO deals.

The 1990 s and the early 2000 s were a period of rapid development of the primary syndicated loan market (Refer to the chart presented below). LBO activities again became important segments of the market after the amount of LBO syndicated loan market reached its highest in year 1988 and 1989 and then dropped dramatically to $\$ 11$ billion in 1990 (Yago \& McCarthy, 2004). In addition, Yago and McCarthy (2004) indicate that in the last decade, private equity groups have raised hundreds of billions to fund future acquisitions, much of which has not yet been spent. They also find that after a two to three year lull, private equity funds raised new commitments like never before, with $\$ 35$ billion being raised in the first quarter of 2005 alone, compared to less than $\$ 50$ 
billion for the entire year in 2004 .

Figure A.1 LBO Syndicated Issuance 1987-2003

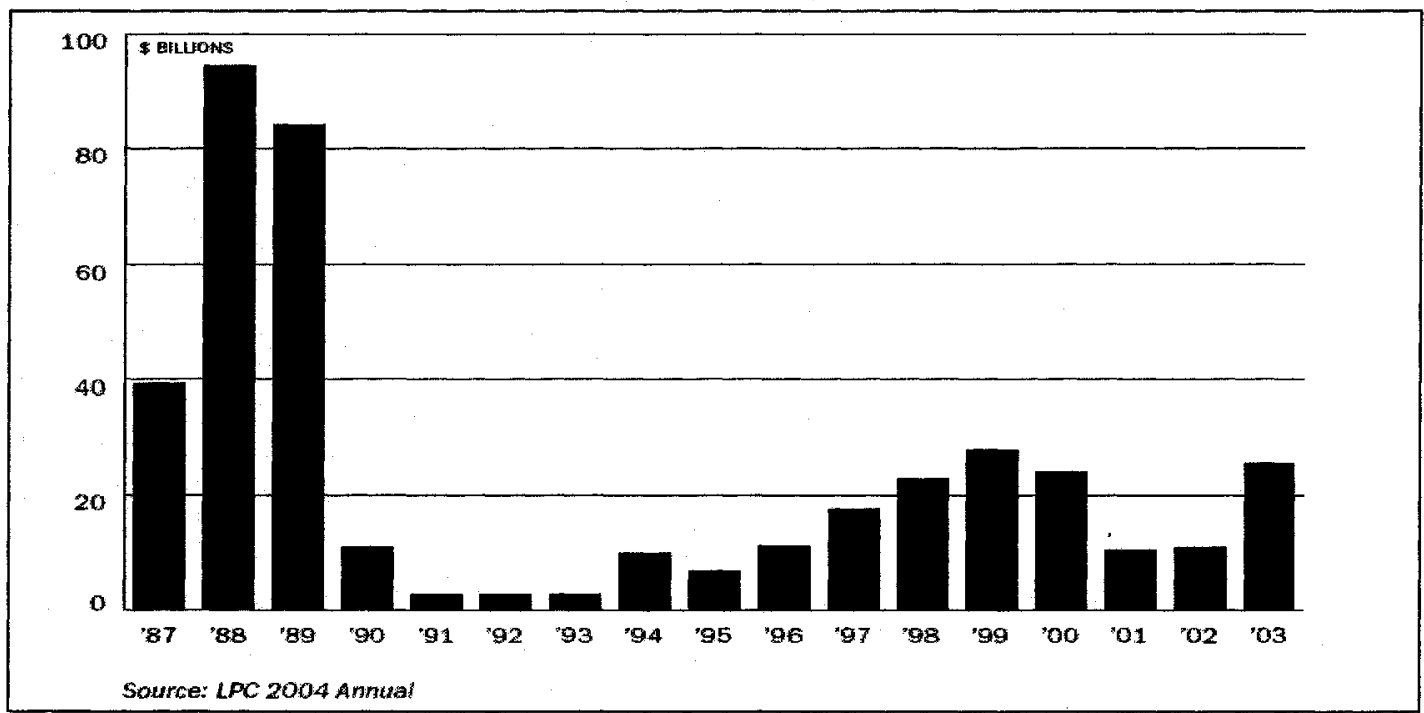

2) Leveraged Loan Default Rate

Leveraged loan default rate has dramatically increased since 1997 from below 1 to above 7 and it is much higher than the early 1990s (Refer to the chart presented subsequently). Furthermore, the default rate is very high in the industries such as consumer durables, food and drug, and media/telecom (Refer to the table presented subsequently). Theoretically, the high default rate accompany with low U.S.'s GDP growth rate should deter the occurrences of LBOs in the above industries. However, data from Thomas Financial Database shows that the recent LBOs have occurred more in the media/telecom industry. In this situation, there is a possibility that the current LBO market might be overheated, though the high default rate in some industries have not had actual effects on 
the LBO market yet. ${ }^{55}$

Figure A.2 Default Rates and Economic Growth, 1992-2002

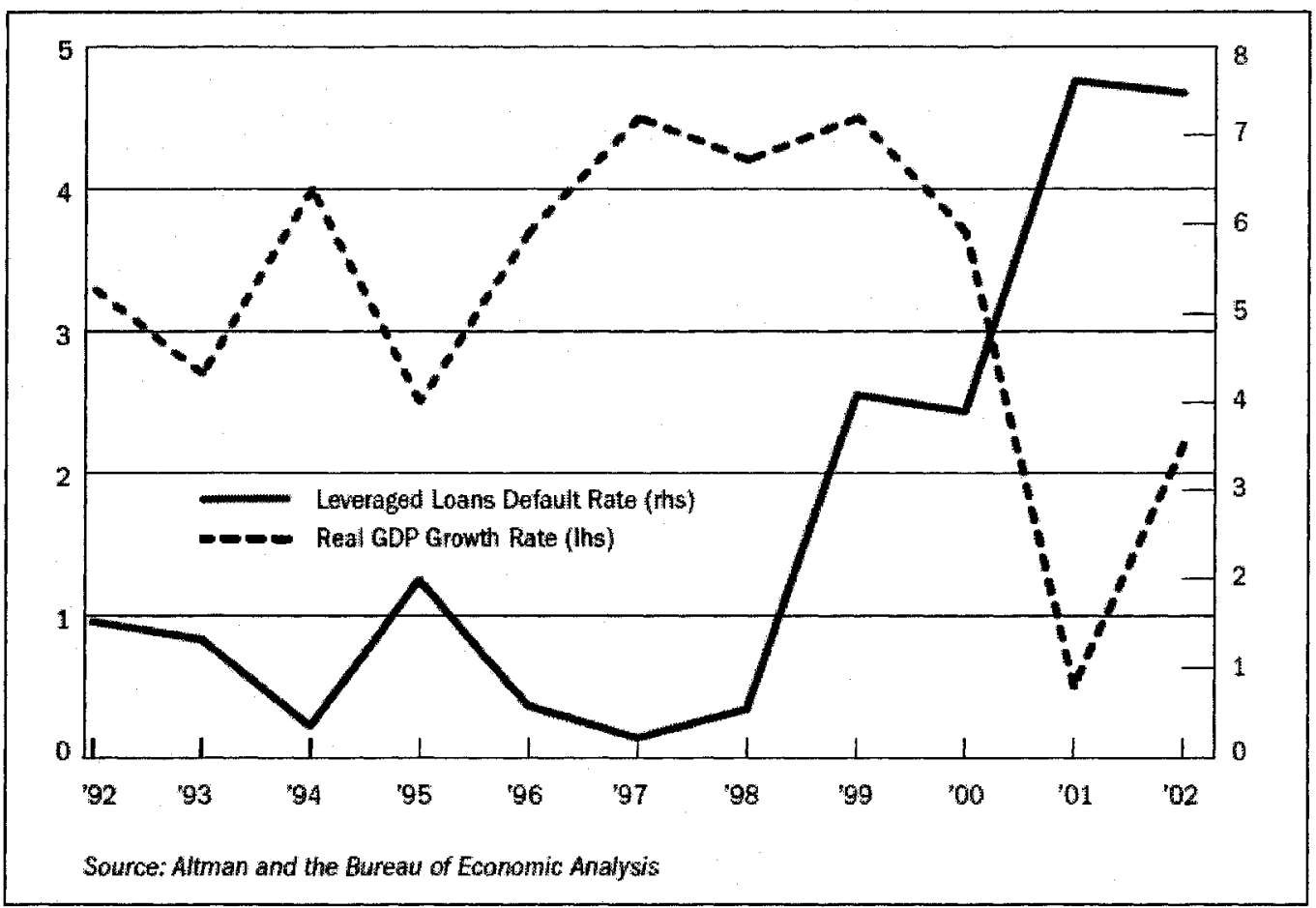

\footnotetext{
${ }^{55}$ There may be another explanation to justify the fact that the popularity of LBOs and high leveraged loan default rate coexist: The above default rate of leveraged loan may be due to the effects of dot.com bubble busted in 2000 on the venture capitalists' performance. Therefore the investment activity has turned in to less volatile later stage investing that also the buyouts represent to not only avoid high risk but also take advantage of higher returns in some fast growing industries.
} 
Table A.1 Annual Leveraged Loan Default Rates by Industry, 1995-2004

\begin{tabular}{|c|c|c|c|c|c|c|c|c|c|c|c|}
\hline Industry & 1995 & 1996 & 1997 & 1998 & 1999 & 2000 & 2001 & 2002 & 2003 & $1 \mathrm{HO4}$ & $\begin{array}{l}\text { Average } \\
1995- \\
1404\end{array}$ \\
\hline Chemical & $0.40 \%$ & $0.00 \%$ & $0.00 \%$ & $1.11 \%$ & $0.92 \%$ & $1.55 \%$ & $4.85 \%$ & $3.14 \%$ & $2.67 \%$ & $2,15 \%$ & $1.68 \%$ \\
\hline Consumer Durables & $0.00 \%$ & $0.00 \%$ & $0.00 \%$ & $0.00 \%$ & $26.84 \%$ & $2.10 \%$ & $6.73 \%$ & NA & NA & MA & $5.09 \%$ \\
\hline Consumer Non-Durables & $1.96 \%$ & $1.14 \%$ & $0.65 \%$ & $3.01 \%$ & $4.43 \%$ & $7.09 \%$ & $6.28 \%$ & $2.98 \%$ & $4.01 \%$ & $1.14 \%$ & $3.27 \%$ \\
\hline Energy & $0.18 \%$ & $0.33^{2}$ & $0.00 \%$ & $0.36 \%$ & $7.50 \%$ & $0.21 \%$ & $0.0 \% \%$ & $1.28 \%$ & $1.54 \%$ & $61.68 \%$ & $131 \%$ \\
\hline Food and Drug & $8.50 \%$ & $0.26 \%$ & $0.22 \%$ & $5.78 \%$ & $9.26 \%$ & $8.89 \%$ & $1.59 \%$ & $1.02 \%$ & $9.66 \%$ & MA & $5.02 \%$ \\
\hline Forest Prod/Containers & $0.00 \%$ & $1.18 \%$ & $0.00 \%$ & $0.41 \%$ & $0.29 \%$ & $1.60 \%$ & $9.54 \%$ & $1.61 \%$ & $0.67 \%$ & $60.32 \%$ & $1.56 \%$ \\
\hline Gaming/Leisure & $2.28 \%$ & $0.50 \%$ & $0.00 \%$ & $0.36 \%$ & $1.35 \%$ & $2.11 \%$ & $0.97 \%$ & $0.18 \%$ & $0.21 \%$ & $0.21 \%$ & $0.82 \%$ \\
\hline Healthcare & $0.49 \%$ & $0.00 \%$ & $0.00 \%$ & $0.26 \%$ & $9.85 \%$ & $3.50 \%$ & $1.13 \%$ & $0.19 \%$ & $6.12 \%$ & MA & $239 \%$ \\
\hline Mantufacturing & $0.00 \%$ & $1.04 \%$ & $0.43 \%$ & $0.00 \%$ & $270 \%$ & $3.18 \%$ & $7.64 \%$ & $2.76 \%$ & $1.78 \%$ & $1.10 \%$ & $206 \%$ \\
\hline Media/Telecon & $0.80 \%$ & $1.07 \%$ & $0.46 \%$ & $1.00 \%$ & $1.55 \%$ & $2.13 \%$ & $13.17 \%$ & $29.57 \%$ & $305 \%$ & $1.67 \%$ & $5.45 \%$ \\
\hline Metals/Minerals & $0.00 \%$ & $0.00 \%$ & $0.00 \%$ & $0.87 \%$ & $5.57 \%$ & $7.19 \%$ & $11.08 \%$ & $8.95 \%$ & $3.72 \%$ & $1.47 \%$ & $3.88 \%$ \\
\hline Utility & $0.00 \%$ & $1.75 \%$ & $0.47 \%$ & $0.00 \%$ & $0.93 \%$ & $0.43 \%$ & $12.29 \%$ & $9.10 \%$ & $2.15 \%$ & $61.32 \%$ & $284 \%$ \\
\hline Source: CSFB & & & & & & & & & & & \\
\hline
\end{tabular}

3) Interest Rates and GDP Growth Rate

The main impact of interest rates on the LBO market is that the lower interest rates can make debt component of the LBO transactions more affordable, while the effect of GDP growth rate on the LBO market is that the optimism increases the perceived ability of post-LBO to cover heavy debt burden. The valuation of individual deals is thus affected by overall macroeconomic conditions and past industry performance (Gompers \& Lerner, 2000). Empirically, the interest rates generally show decreasing trend over the period of 1980-2005 and GDP growth rate in recent years is much higher than in the 1990s. These macro economic factors may keep heating the LBO market by providing cheap debt and good economic environment. 
Figure A.3 1-Year U.S. Treasury Bill Rate

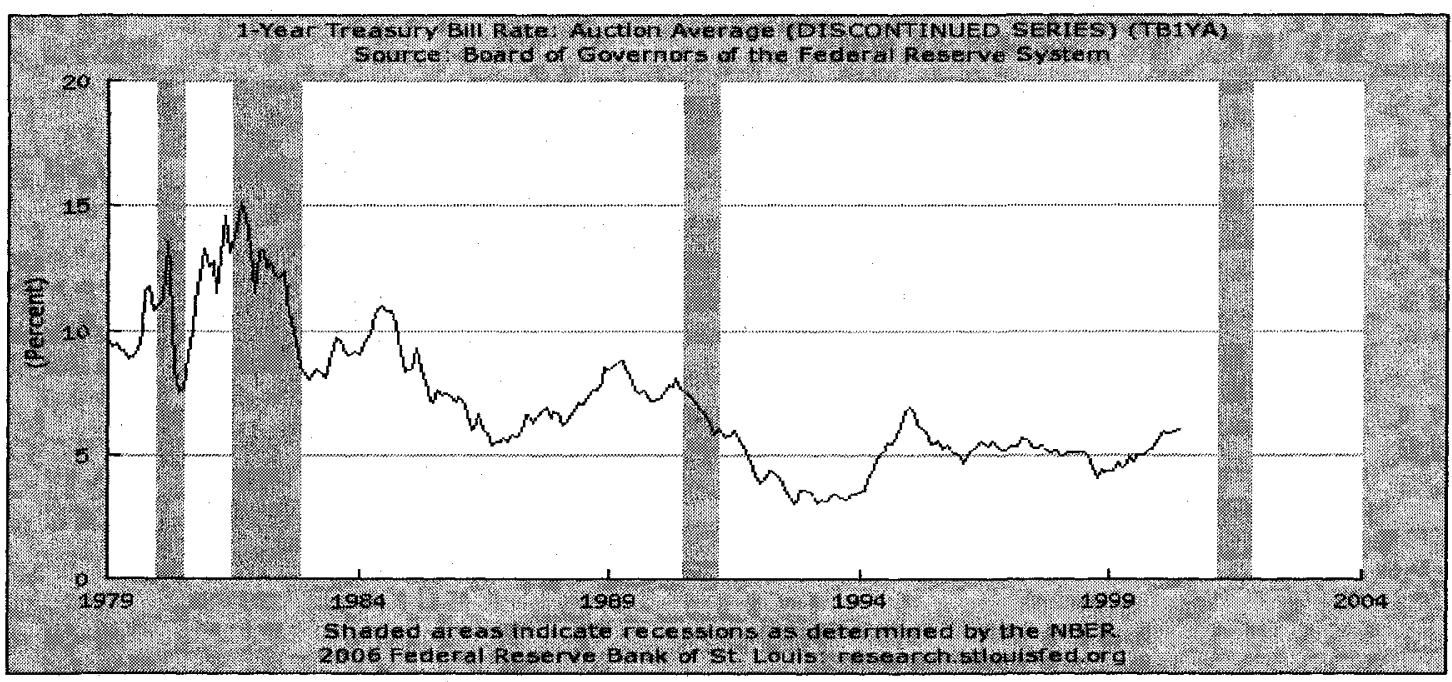

\section{4) Global LBO Market}

The number of cross-country deals has been increasing over the past few years and, interestingly, the LBO market followed a similar increasing trend for cross-country LBOs in the 1980s (Refer to the subsequent chart). The increasing number of cross-country deals implies that current LBO market is transitioning toward a global LBO market. Armanno Andrea Pappalardo ${ }^{56}$ also indicates that the U.S. LBO market has evolved from a "deal" business to an "investment" business with partnerships of business and financial professionals becoming increasingly critical. In addition to the increasing number of cross-country LBO deals, the robust LBO markets outside the U.S. may also greatly impact the way U.S. equity funds evaluate LBOs and the U.S. LBO market ${ }^{57}$.

\footnotetext{
56 http://www.altassets.net/knowledgebank/surveys/lists/hm surveys.php

${ }^{57}$ For example, LBOs have been growing in Europe since 1990s. The United Kingdom has witnessed explosive growth in these transactions. It is possible that the availability of LBO buyout targets in the U.K. and the occurrence of more cross country deals may have great impact on the U.S. LBO market.
} 
Figure A.4 Number of Cross-Country LBO Deals

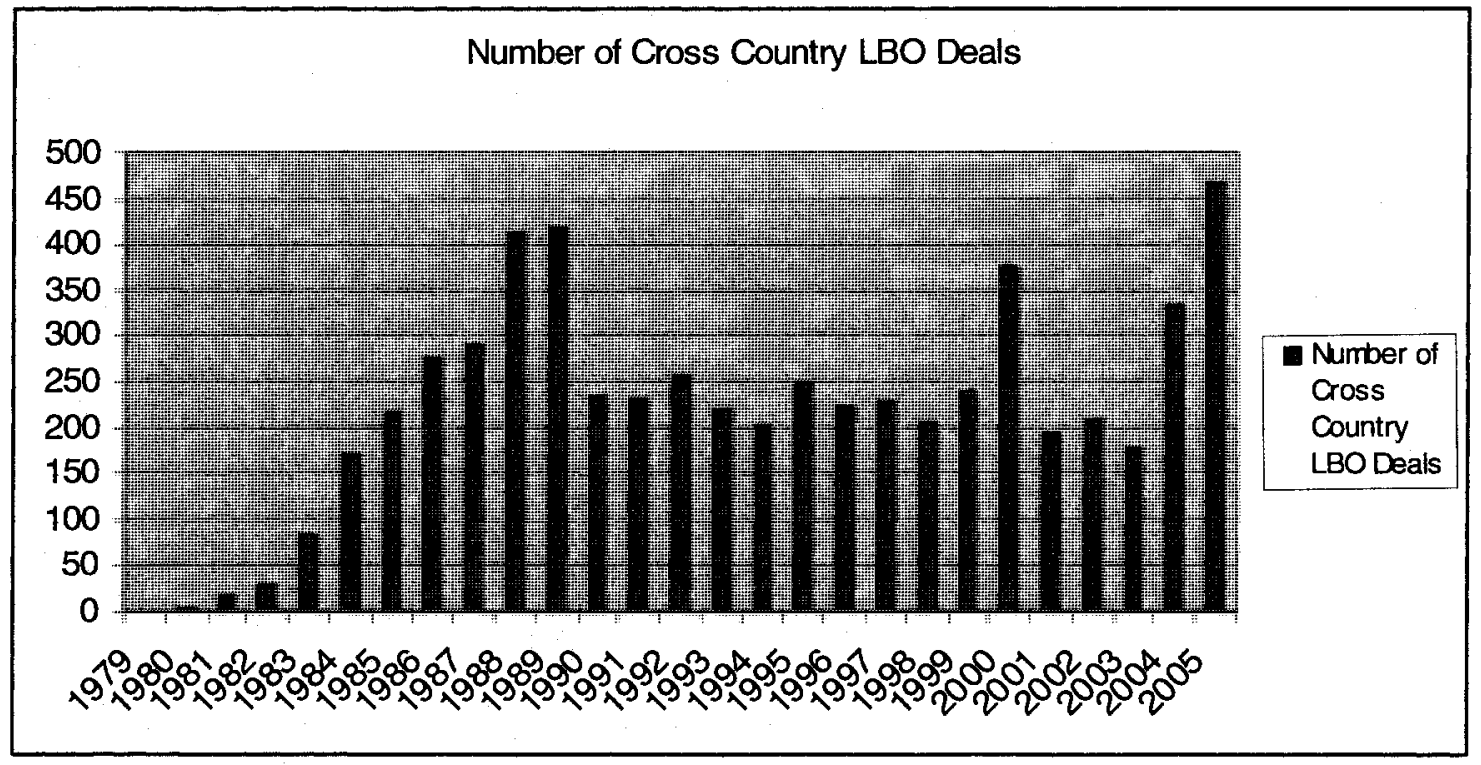

Source: Raw Data from SDC database

\section{5) Overbidding}

Weston and Chen (1994) find overbidding for many going-private transactions at the end of the $1980 \mathrm{~s}$, due to high competitive pressure from the many buy-out funds that were raised at the time attracted by the high returns in the early 1980s. Gompers and Lerner (2000) find that an increase in funds raised and in the number of private equity investors results in higher valuations and lower returns ("too much money chasing too few deals"). A doubling of funds raised by private equity firms results in a valuation level increase of $7 \%$ to $21 \%$. They argue that the relation between increased fundraising and prices does not appear to be due to greater perceived investment prospects.

6) Transformation of Financial Institutions' Roles as Financial Buyers to Strategic Buyers 
Smit and Maeseneire (2005) indicate that private equity investors used to be mainly financial investors during the 1990s, however, they have become active competitors of strategic players, searching for synergies. Besides more traditional type of buyouts, in which cost reduction and strategic reorientation are the key value drivers, there are also buyouts that derive their value mainly from product development, innovation and exploiting entrepreneurial growth opportunities.

The following figure also provides an interesting conjecture that the LBO deals evolve from standard LBOs to deep restructuring LBOs in recent years.

\section{Figure A.5 Deal Profile Evolution of LBOs}

\section{Deal profile evolution: from "standard" $L B O$ s to "deep restructuring" $L B O$ s}

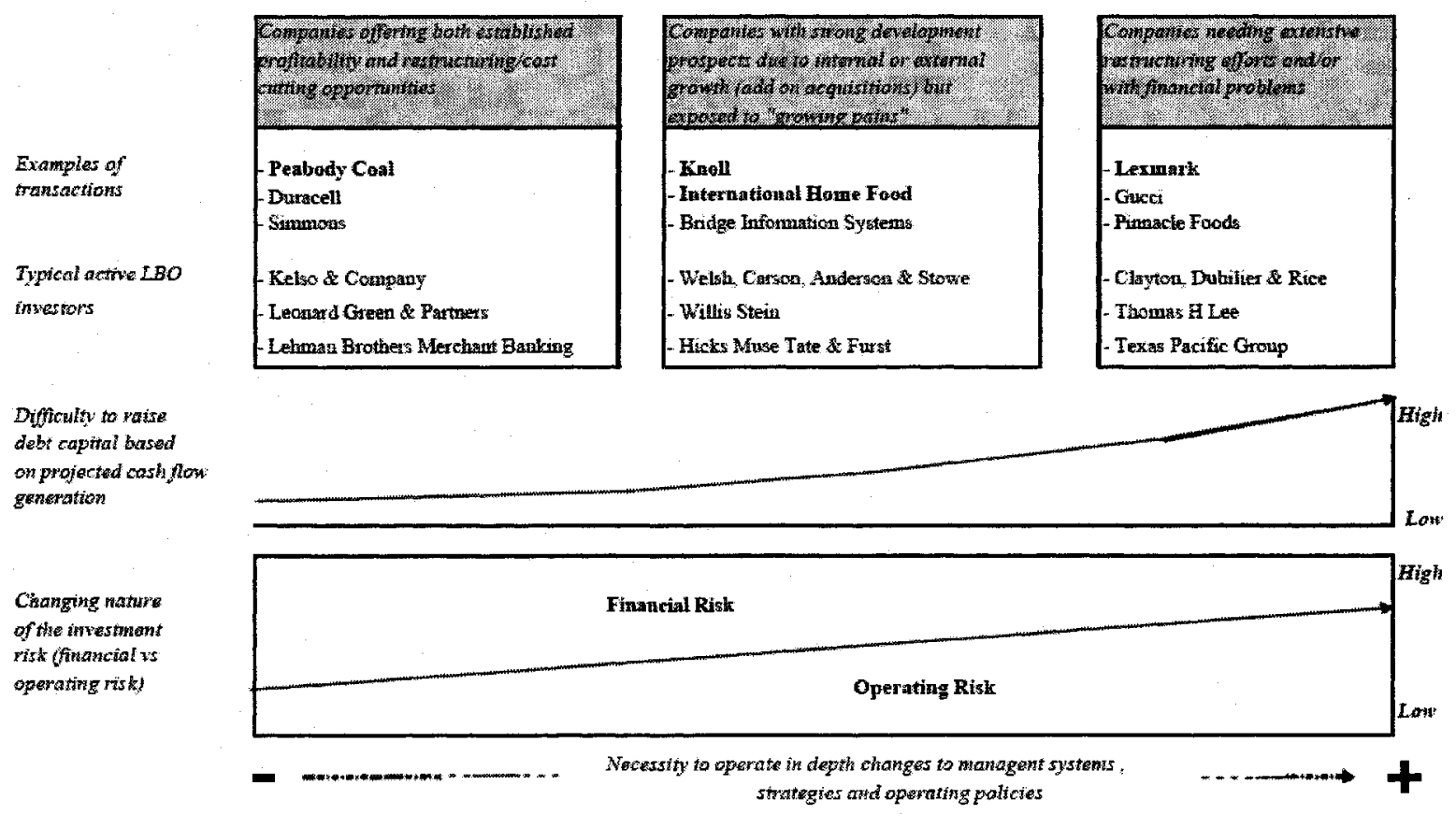

Source: AltAssets (http://www.altassets.net) 
7) Changing Industries in which LBOs Occur

In terms of the industry in which LBOs occur, researchers and practitioners such as Allen (1996) and Smit and Maeseneire (2005) make casual comments that the LBO market moved to high-growth, technology-driven industries during the 1990s, although most LBOs in the 1980s took place in mature, slow-growing industries. Our raw data from SDC Thomas Financial Database further shows that manufacturing industry began out of favor in LBO market in the 2000s, and LBO market has been shifting from manufacturing industries towards service industries, which are harder to leverage due to the higher intangible asset base.

In conclusion, there have been increasing popularity of LBO deals, the aggressive LBO evaluation, new industries where LBOs have occurred, greater availability of private equity, and aggressiveness of lending activities of financial institutions, higher default rate and lower GDP growth rate, industry change, and robust market outside the U.S. 


\section{APPENDIX B: SAMPLE SIZE AND SAMPLE PERIOD OF THE KEY STUDIES ON U.S LBOS}

A summary of sample size and sample period of the key studies on U.S. LBOs (not

limited to the three research subtopics of this study) is provided as follows.

Table B1: Sample Size and Sample Period of the Key Studies on U.S LBOs

\begin{tabular}{|c|c|c|c|}
\hline Article category & Literature & Sample period & Sample size \\
\hline \multirow{18}{*}{$\begin{array}{l}\text { Stock } \\
\text { performance } \\
\text { around LBO } \\
\text { announcement }\end{array}$} & Travlos and Cornett (1993) & $1975-1983$ & 56 \\
\hline & Madden, Marples, and Chugh (1990) & $1973-1978$ & $36 \mathrm{MBOs}$ \\
\hline & Carow and Roden (1998) & $1981-1990$ & 88 \\
\hline & DeAngelo, DeAngelo, and Rice (1984) & $1973-1980$ & 72 \\
\hline & Torabzadeh and Bertin (1987) & $1982-1985$ & 48 \\
\hline & Marais, Schipper, and Smith (1989) & $1974-1985$ & 79 \\
\hline & Lehn and Poulsen (1989) & $1980-1987$ & $\begin{array}{l}244 \text { going-private } \\
\text { transactions }\end{array}$ \\
\hline & Kieschnick (1998) & $1980-1987$ & $\begin{array}{l}244 \text { going-private } \\
\text { transactions }\end{array}$ \\
\hline & Bae and Simet (1998) & $1985-1990$ & 21 \\
\hline & Amihud (1989) & $1983-1986$ & 15 \\
\hline & Torabzadeh and Bertin (1987) & $1982-1985$ & 48 \\
\hline & Travlos and Millon (1987) & $1975-1983$ & 56 \\
\hline & Eastwood (1998) & $1982-1989$ & 41 \\
\hline & Kaplan and Stein (1990) & $1985-1988$ & 12 \\
\hline & Bruton, Keels, and Scifres (2002) & $1980-1988$ & 39 \\
\hline & Kosedag and Lane (2002) & $1980-1996$ & 21 \\
\hline & Holthausen, and Larcker (1996) & $1985-1986$ & 90 reversed LBOs \\
\hline & Kaplan (1989) & $1980-1985$ & 48 \\
\hline \multirow{3}{*}{$\begin{array}{l}\text { Premiums paid to } \\
\text { shareholders of } \\
\text { LBOs }\end{array}$} & Lehn and Poulsen (1989) & $1980-1987$ & $\begin{array}{l}244 \text { going-private } \\
\text { transactions }\end{array}$ \\
\hline & Halpern, et al (1999) & $1981-1986$ & 126 \\
\hline & Kieschinick (1989) & $1980-1987$ & $\begin{array}{l}244 \text { going-private } \\
\text { transactions }\end{array}$ \\
\hline \multirow{12}{*}{$\begin{array}{l}\text { Post-buyout } \\
\text { operating } \\
\text { performance of } \\
\text { LBOs }\end{array}$} & Lichtenberg and Siegel (1990) & 1981-1986 & 131 \\
\hline & Mian and Rosenfeld (1993) & $1983-1988$ & 85 reversed LBOs \\
\hline & Muscarella and Vetsuypens (1990) & 1976-1987 & 72 reversed $\mathrm{LBOs}$ \\
\hline & Noronha and Yung (1997) & $1984-1990$ & 120 reversed LBOs \\
\hline & Opler (1992) & $1985-1989$ & 44. \\
\hline & Roden and Lewellen (1995) & $1981-1990$ & 107 \\
\hline & Phan and Hill (1995) & 1986-1989 & 214 (Survey) \\
\hline & Smith (1990) & $1977-1986$ & 58 \\
\hline & Chatfield and Newbould (1996) & 1989 & 13 \\
\hline & Chevalier (1995) & 1981-1990 & N/A \\
\hline & DeAngelo and DeAngelo (1985) & 1973-1982 & 33 \\
\hline & Opler and Titman (1993) & $1980-1990$ & 180 \\
\hline $\begin{array}{l}\text { Overheated } \\
\text { market hypothesis }\end{array}$ & Kaplan and Stein (1993) & $1980-1989$ & 124 \\
\hline \multirow{3}{*}{$\begin{array}{l}\text { Characteristics of } \\
\text { firms going } \\
\text { private via LBO }\end{array}$} & Kieschinick (1989) & 1980-1987 & 244 \\
\hline & Halpern, et al (1999) & 1981-1986 & 126 \\
\hline & Kaplan and Stein (1993) & 1980-1989 & 126 \\
\hline \multirow[t]{3}{*}{ Others } & Kaplan (1991) & 1979-1986 & 183 \\
\hline & Roden and Lewellen (1995) & $1981-1990$ & 107 \\
\hline & Jandik and Makhija (2005) & 1981-1995 & 250 takeovers \\
\hline
\end{tabular}




\section{APPENDIX C: LITERATURE REVIEW ON LBO DEFINITION USED IN THE PREVIOUS LITERATURE}

There are following four different groups of definitions of LBOs provided by existing studies, despite the fact that all these papers assume that using highly leveraged capital structure and $100 \%$ of firms being taken private as two key features for a firm to be considered as an LBO.

\section{1) Management-led Buyout}

DeAngelo et al (1984) define LBOs as "management proposes to share equity ownership in the subsequent private firm with third-party investors". Similarly, Green (1992) posits that the two key features of LBOs are the managerial based ownership structure and the highly leveraged capital structure. Obviously, these studies use term LBO and MBO interchangeably.

\section{2) Leveraged Buyout}

Without specifying the role of management in an LBO transaction, Stancill (1988) indicates that "whenever a buyer lacks the requisite cash and borrows part of the purchase price against the target company's assets, it is an LBO”. Lehn and Poulsen (1989) also give a vague definition: "in going private transactions, shareholders of a publicly held corporation are bought out, typically at a large premium, by a bidder who takes a concentrated ownership position in a reconstituted, privately held firm". Kaplan and Stein (1993) use the definition provided by SDC database, which is also consistent with this category of LBO definition. Myriam Gasqué defines a leveraged buy-out (LBO) as a 
takeover of a company, using borrowed funds. Most often, the target company's assets serve as security for the loans taken out by the acquiring firm (the holding), which repays the loan out of cash flow of the acquired company. Garfinkel (1989) and Travlos and Cornett (1993) define an LBO as a highly leveraged, going-private transaction and clearly specify the acquirer can be an outside individual, another firm or the incumbent management. In addition to the above criteria, Halpern et al (1999) add the minimum requirement of debt financing and requires over $50 \%$ debt financing for a firm to be considered an LBO.

\section{3) Institution-led Buyout}

Halpern et al (1998) restrict LBOs as the corporations acquired by investment groups.

\section{4) Public-to-private Transactions}

Weir, et al (2005) and Lehn and Poulsen (1989) both directly point out that leveraged buyout and management buyout are the two most commonly used terms for public-toprivate transactions, "because the public-to-private transactions are often heavily financed by debt and the bidding party often includes the existing management team". Obviously, the studies in this group use public-to-private transactions interchangeably with $\mathrm{LBO}$ and MBO.

Based on the above categorization of LBO definitions in the existing studies, it can be seen that different samples are examined in the existing research on LBO. 


\section{APPENDIX D: MAJOR OBSERVATIONS ON CHANGING DEAL CHARACTERISTICS OF LIBOS AND LMBOS BASED ON RAW DATA OF THIS STUDY}

Based on raw data of this study, this study has the following major observations on changing deal characteristics of LIBO and LMBO transactions over the period 19852005.

1) There have been an increasing number of LIBO transactions that have occurred since the mid 1990s. Moreover, the number of LIBO transactions almost doubled compared to the number of LMBOs in some years in the period 1995-2005.

Figure D.1 Yearly Distribution of Numbers of LIBO and LMBO Transactions

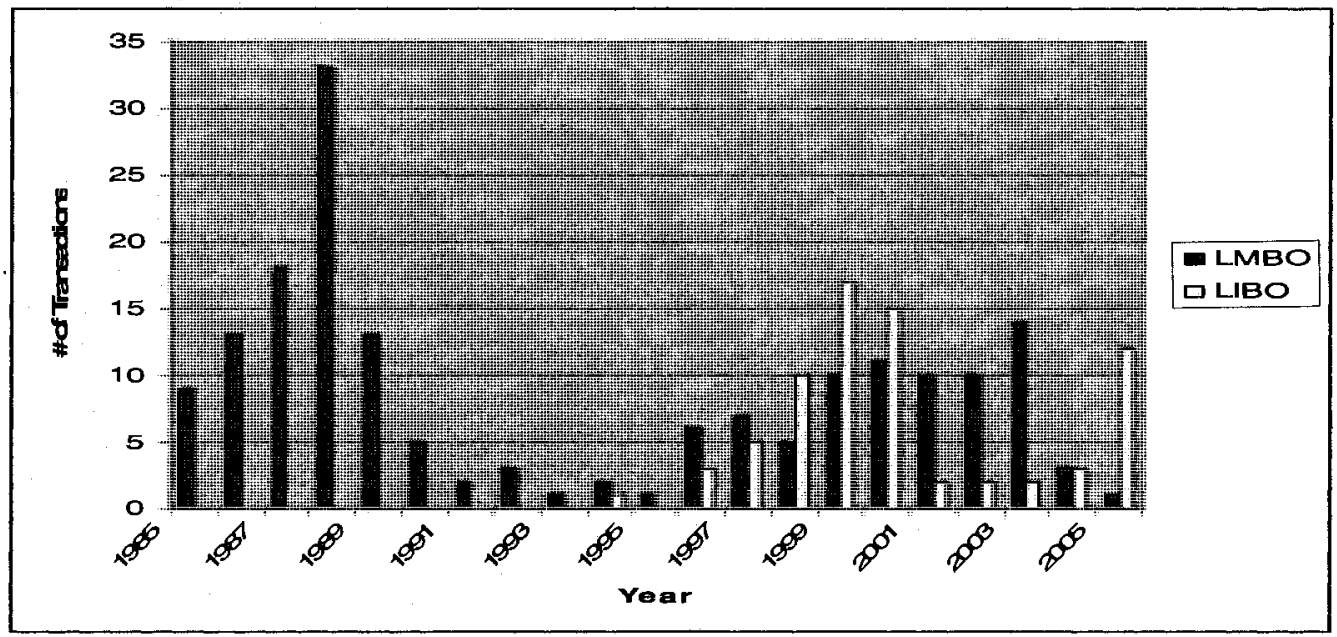

2) Total transaction value of both LMBOs and LIBOs has increased significantly since the mid 1990s. Especially, total transaction value of LIBOs in year 2005 exceeded the combined total transaction value of both LMBOs and LIBOs in any previous year. Also, consistent with the overheated market hypothesis, total transaction value of LMBOs is found to peak at the end of the 1980s. 
Figure D.2 Yearly Distribution of Total Transaction Value of LIBOs and LMBOs

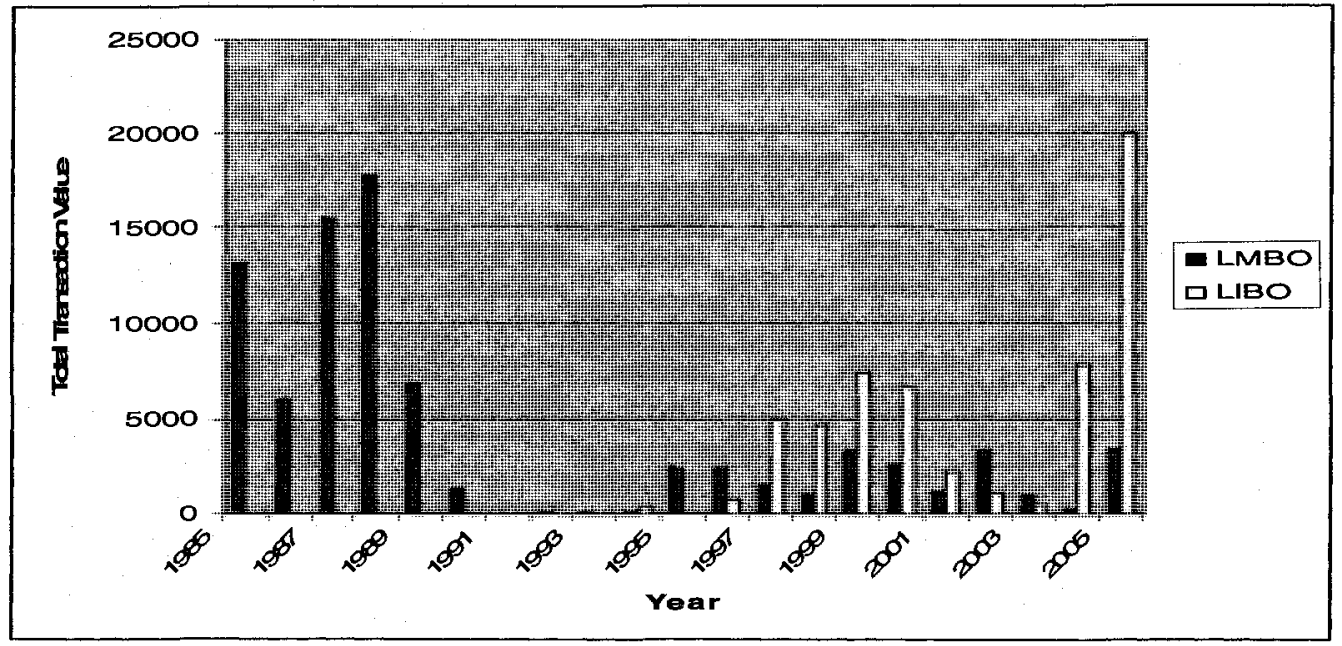

Note: in millions

3) Deal sizes of both LIBOs and LMBOs have increased significantly in recent years and deal sizes of both LMBOs and LIBOs in year 2004 and 2005 exceed deal sizes of LIBOs and LMBOs in any previous years. ${ }^{58}$

Figure D.3 Yearly Distribution of Deal Size of LIBOs and LMBOs (Median)

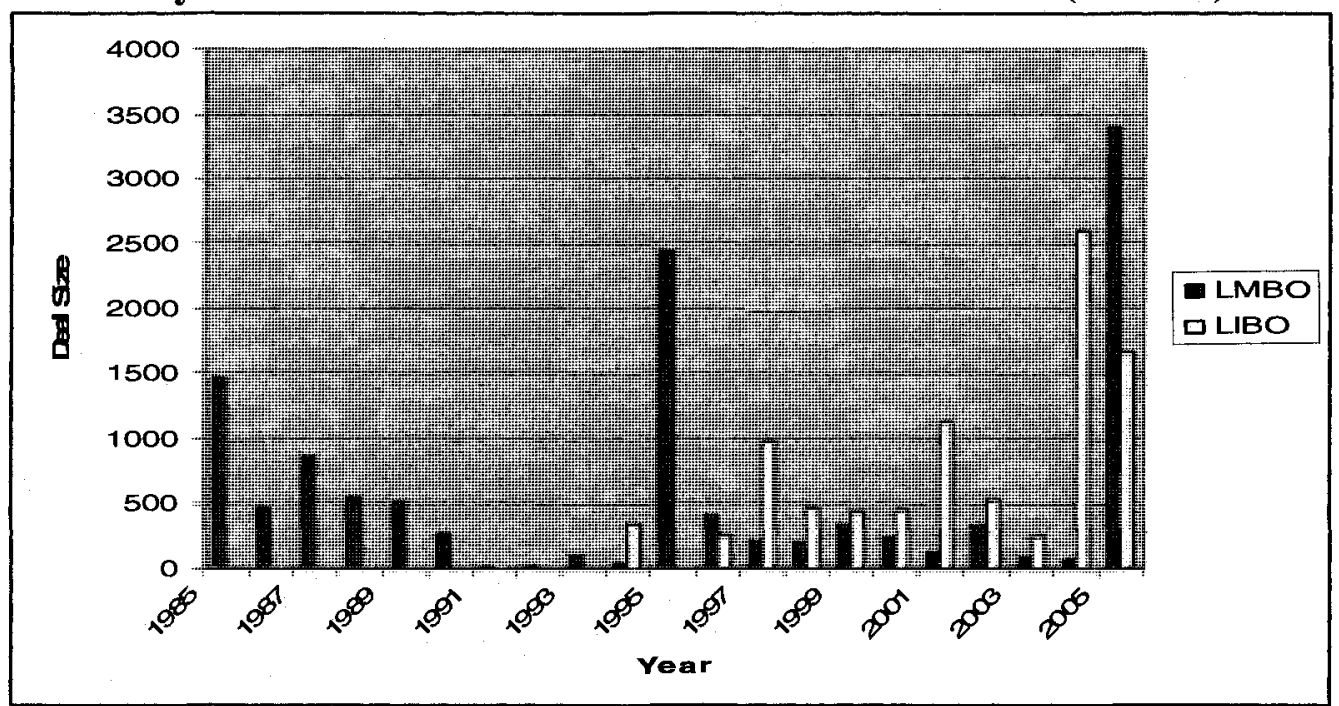

Note: in millions

58 Note that there was only 1 LMBO that occurred in year 1995, so the deal size of LMBO in that year only reflects that particular case. It might be an extreme case. 
4) There were a greater number of challenged LMBOs in the late 1980s than in recent years. Compared to LIBOs, there were a larger percentage of challenged LMBOs over the period 1995-2005.

Figure D.4 Yearly Distribution of Percentage of Challenged Deal among LIBOs and LMBOs

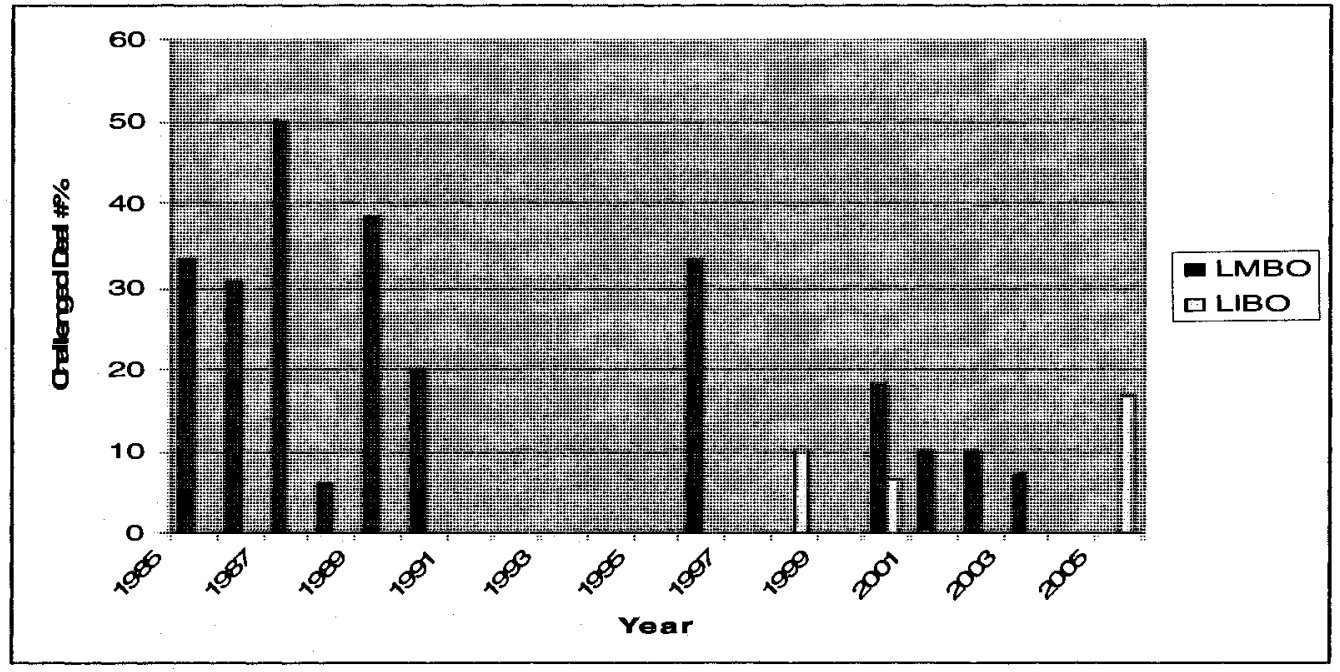

5) Acquirers of LBO targets were more conservative about assuming liability during the transactions in the 1990 s than in the late 1980 s or the early 2000 s. Furthermore, this study finds that acquires of LBO targets usually kept the assumed liability-transaction ratio at around $60 \%$ or higher over the period 1985 2005. 
Figure D.5 Yearly Distribution of Debt/Transaction Value of LIBOs and LMBOs (Median)

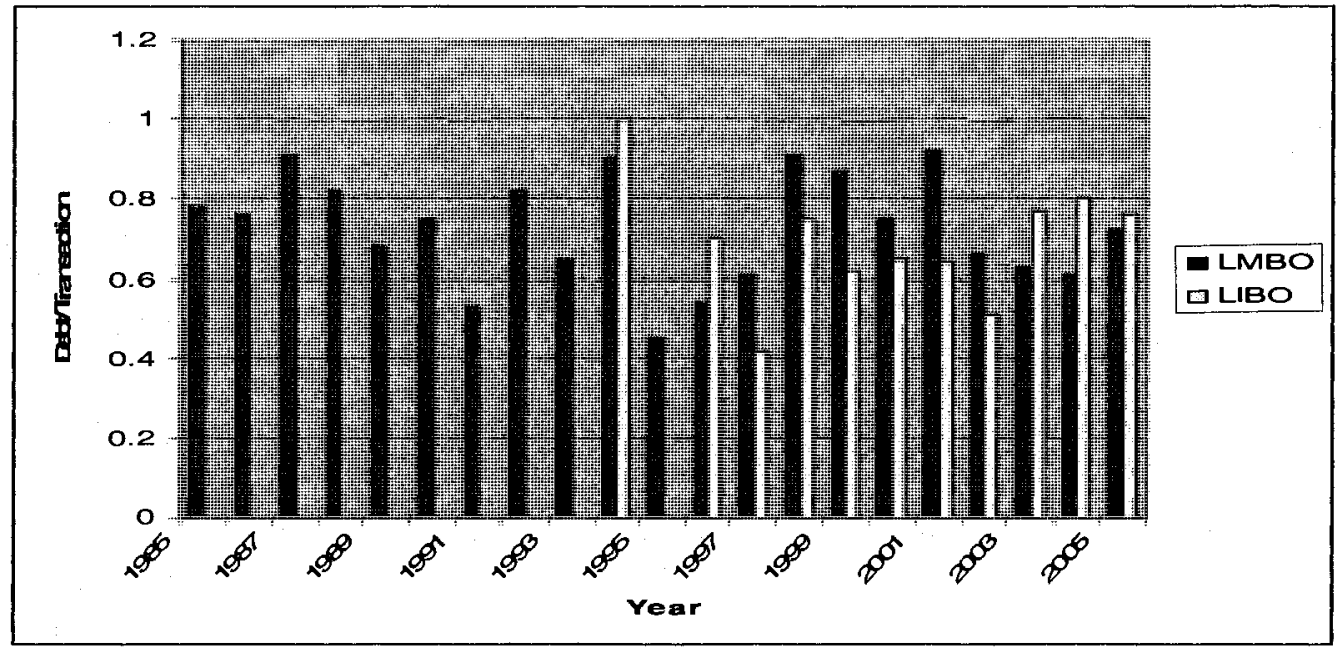

6) There is a high volatility in the premiums paid for LMBO and LIBO targets in recent years, while the premiums paid for LMBOs in the late 1980s generally lie in the range between $30 \%$ and $40 \%$.

Figure D.6 Yearly Distribution of Premiums 1 Week Prior to Announcement of LIBOs and LMBOs (Median)

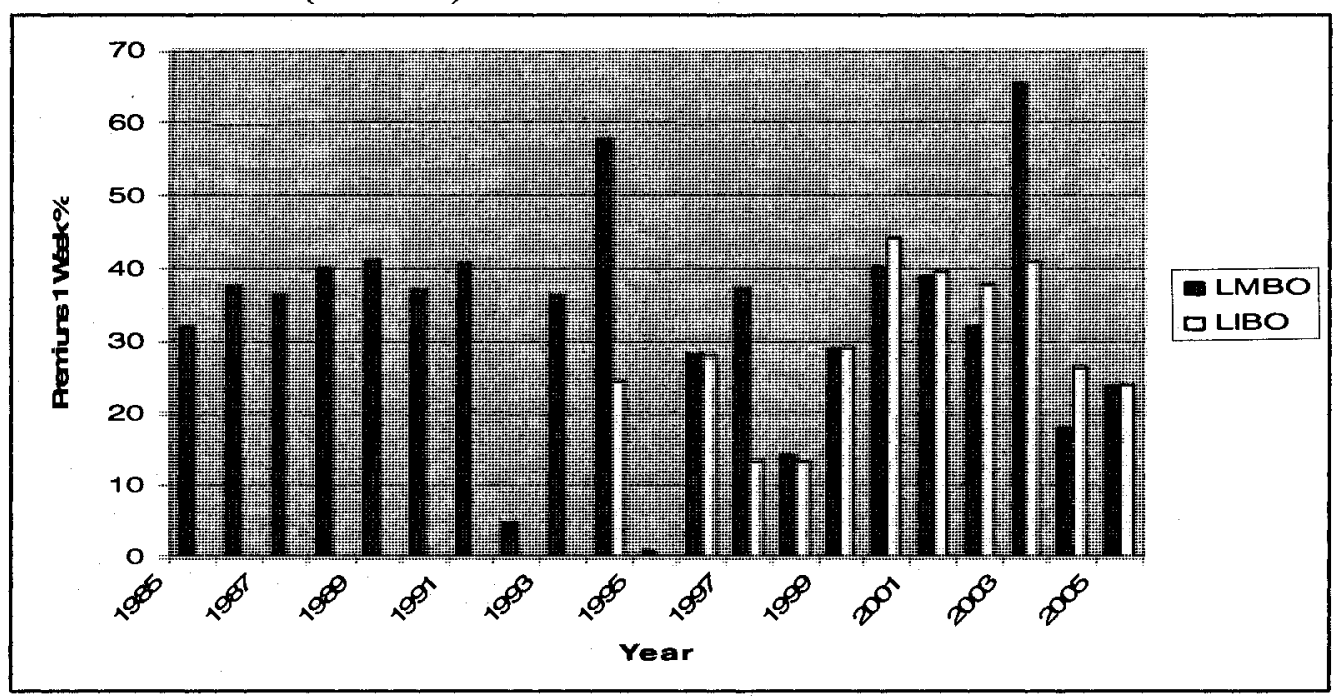




\section{APPENDIX E: GENERAL LITERATURE REVIEW ON THE RELATED RESEARCH SUBTOPICS ON LBOS (NOT COVERED BY THIS STUDY)}

There are seven research topics in LBO literature and they include: 1) The overheated buyout market hypothesis; 2) Factors explaining the premiums paid to pre-shareholders of LBO firms; 3) Factors explaining the likelihood of firms' going private via LBOs; 4) Deal structure of LBO transactions; 5) Post-LBO firms' operating performance improvement after LBO transactions; 6) Reverse-LBO firms' performance; 7) Re-LBO firms' performance.

The overall framework for the review of the literature on LBOs is provided in Figure E.1, which shows the full public-private-public ownership cycle of LBO transactions: At the beginning of the cycle, some public firms go private via LBOs; Then some of these LBO firms re-obtain public status after a few years of being private (these firms are called reverse-LBOs); At the end of the cycle, some of these reverse-LBOs return private again via re-LBOs. Therefore, by focusing on the certain stage of the full LBO cycle, all the existing papers on LBOs attempt to answer the main research question where the value is from. Among the above seven research sub-topics in the area of LBOs, this study focuses on the first public-private stage where public firms go private via LBOs and therefore the first three areas of the literature and related issues. 
Figure E.1 Full Public-private-public Ownership Cycle of LBO Transaction

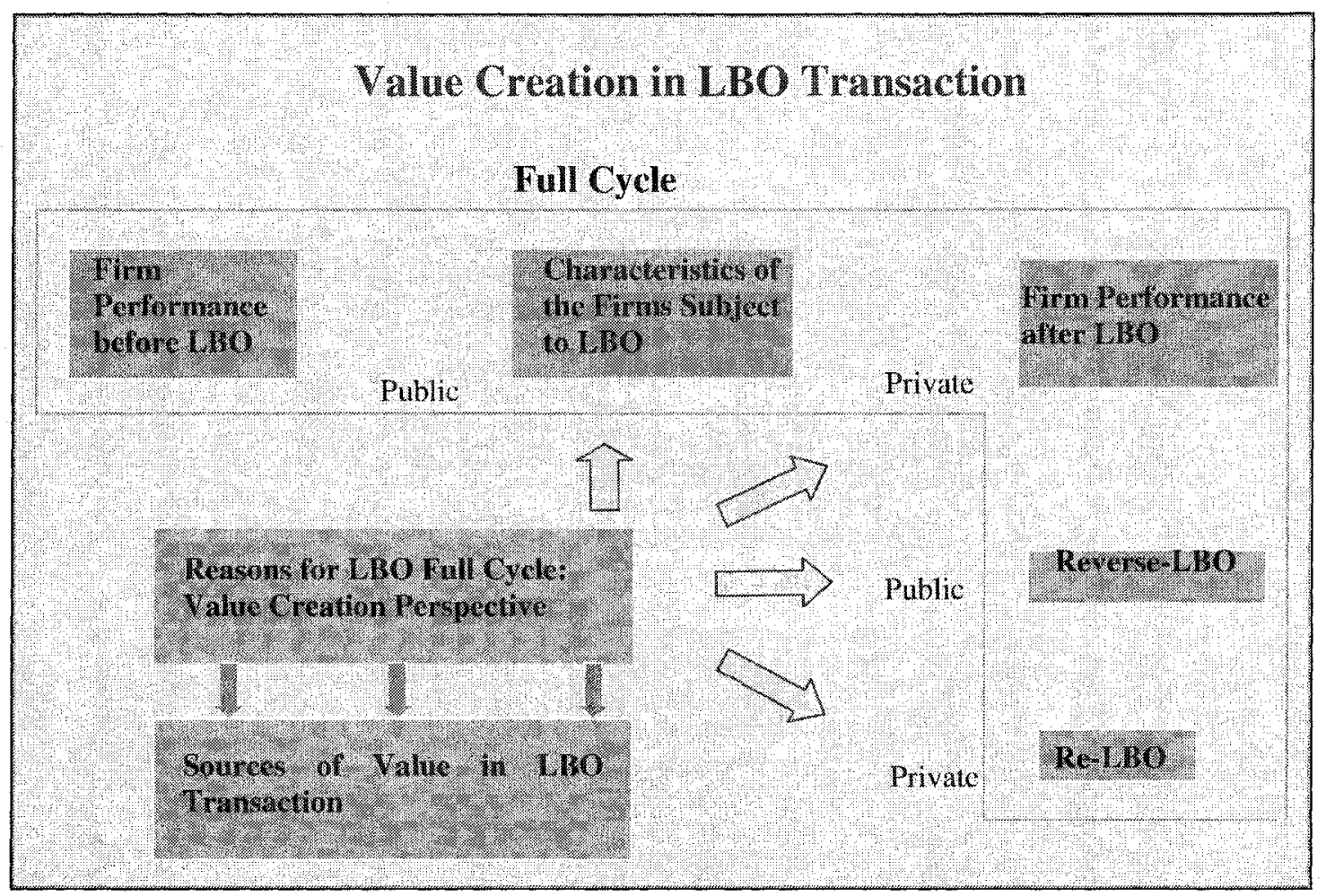

A brief literature review of main papers on the following subtopics is provided below, since the findings of these papers could also shed light on value source of LBOs.

\section{1) Deal Structure}

The principal difference between LBOs and other acquisitions is that a large fraction of the purchase price is financed through debt. Ten-to-one ratios of debt to equity are not uncommon. Kaplan (1989) reports a median debt to total capital ratio of $87.8 \%$ at buyout completion for management buyouts announced between 1979 and 1985. This contrasts with a debt to total capital ratio of only $18.8 \%$ before the buyout. Roden and Lewellen (1995) argue that the choices involved manifest themselves in the various proportions of 
1) senior bank debt, 2) subordinated debt securities, 3) preferred and common stock, 4) cash from the target firm, and 5) proceeds from asset sales, which comprise the financing packages for the transactions.

In terms of how the firms design their financing packages, Roden and Lewellen (1995) find evidence that the prospective cash flow profile of the target firm is a matter of concern for the financing decision. They also imply that default risk is an issue in the capital structure decision process, both for the buyout groups and their lenders, since this suggests an effort to be attentive to the match between debt service obligations and operating cash flows in designing the financing package. Furthermore, Carow and Roden (1998) find evidence that financing packages are designed systematically to respond to differences across firms in their growth prospects, in the variability of their earnings, in their liquidity characteristics, in their plans to sell assets, and in opportunities to achieve tax savings from the deductibility of interest costs.

In terms of future research, Opler and Titman (1993) indicate that, to fully understand the LBO phenomenon, the additional empirical work examining the determinants of the financial structures of LBOs is needed. More specifically, Cotter and Peck (2001) suggest that further research can focus on whether and under what circumstances the presence of active investors of various types will influence the debt structure of LBO firms and their subsequent performance.

2) Operating Performance after LBO Transactions 
From a value creation perspective, one of the most important issues waiting for further exploration is whether real short- and long-term firm performance improves after a LBO or a reversed LBO transaction. Kaplan (1989) finds that operating income, measured net of industry changes, is essentially unchanged in the first two post-buyout years and is $24 \%$ higher in the third year. In addition, the median net cash flow (the difference between operating income and capital expenditures), net of industry changes, in the first three post-buyout years is $22.0 \%, 43.1 \%$, and $80.5 \%$ respectively larger than in the last pre-buyout year. The results for post-buyout operating changes are qualitatively similar to those in Smith (1990), who finds that the buyout firms realize increases in (pre-tax) operating cash flow to operating assets and decreases in capital expenditures to sales. The research consistently demonstrates an operating performance increase after LBOs, but cannot prove that the buyout was the cause of productivity changes.

Some studies argue that the dramatic operating improvements documented in earlier LBOs were due to an unusual abundance of attractive LBO targets and that the number and type of firms that can be revitalized through LBOs is limited. Kaplan (1989) raises a possible methodological issue that the measured increase in operating income might be a by-product of postponed maintenance expenditures. Under this view, the buyout companies are so heavily burdened by debt that they fail to invest in positive net present value projects and activities. This would destroy rather than create value. Previous studies including Kaplan and Stein (1993), Long and Ravenscraft (1993), Muscarella and Vetsuypens (1990), and Kaplan (1989) have also shown that there are few changes in employment, R\&D, and maintenance expenditures following LBOs. Bruton, Keels, and 
Scifres (2002) argue that performance may be measured in a multiplicity of ways, and that the interpretation of performance outcomes can change substantially depending upon the benchmark comparison standards employed.

With regarding to future research, it is argued that most of the previous studies dealing with post-buyout performance are short-term in nature and more research is needed about the long-term effects of LBOs. For example, Smith (1998)'s results focus on performance the first year after the buyout. Fox and Marcus (1992) argue that the existing long-term studies, such as Muscarella and Vetsuypens (1990), and Singh (1990), are flawed: they examine only the firms that went private and went public again. These reverse LBOs constitute a small and possibly biased sample. Data with respect to firms that remain private cannot be easily assembled because these firms do not have to make the data publicly available. ${ }^{59}$ Fox and Marcus (1992) also argue that the trade-off between shortterm gains and long-term performances needs to be explored further, if the related data is available.

\section{3) Reverse LBOs}

The buyout firm typically goes through a public-private-public ownership cycle and reverse LBO is defined as the action of offering new shares to the public by companies that initially went private through past LBOs. According to Muscarella and Vetsuypens (1990), Bruton, Keels, and Scifres (2002), and Kaplan (1991), the average private buyout period is approximately 2.28 years. The average public life of these firms following their

\footnotetext{
${ }^{59}$ Studies such as Kaplan and Stein (1993) consult the 10-K fillings, search the WSJ index and read the post-buyout financial statements for post-buyout financial information.
} 
reappearance in the market is 30.74 months, ranging from a minimum of 10.90 to a maximum of 78.36 months.

Kaplan (1991) indicates that as the market value of equity owned by undiversified LBO equity owners increases, the risk-bearing costs of these holdings also increase. The higher these costs, the more likely would be the LBOs' return to public ownership. Kaplan (1991) reveals that the likelihood of returning to public ownership is largest and roughly constant in the second to fifth years after the LBO, and then declines somewhat and is constant thereafter.

Studies like Mian and Rosenfeld (1993) and Noronha and Yung (1997) look only at stock performance, a measure that precludes the possibility of examining the period of private ownership. Holthausen and Larcker (1996) find that as the percentage of equity ownership decreases in a reverse buyout, accounting performance also decreases. But they find that even after the reversal, these firms continue to outperform their industry peers. Muscarella and Vetsuypens (1990) also find that firms which go public again perform better than average, but they argue this may lead to bias if researchers attempt to derive any conclusion on post-LBO performance by only using reverse LBOs.

In terms of future research, Bruton, et al (2002) point out that most of the previous studies focus mainly on the reverse-buyout period, so more research on the full cycle will be necessary. 


\section{4) Re-LBOs}

Kosedag and Lane (2002) define Re-LBO as the practice of going private via leveraged buyout (LBO), re-obtaining public status through a new initial public offering, and then going private a second time. Kosedag and Lane's study finds no empirical support for free cash flow hypothesis of going private transactions, while his tax savings argument of going-private transactions still holds for re-LBOs. 


\section{APPENDIX F: LITERATURE REVIEW ON LBO VALUE SOURCE RELATED THEORIES NOT COVERED BY THIS STUDY}

There are the following LBO value source related theories that are not covered by this study. A brief review of them is provided as follows.

Tax Advantage Hypothesis: Another frequently cited benefit of going private via LBO is a reduction in tax payments. Lehn and Poulsen (1989) point out three tax incentives: the tax deductibility of interest payments on corporate debt; increased depreciation deductions associated with the step-up of assets during going-private transactions; and the tax advantages of financing going-private transactions with employee stock ownership plans (ESOPs). Opler (1992) finds that approximately 50\% of the firms studied paid no income taxes after going private via LBO. This finding implies that many firms use more debt than is needed to eliminate taxes. Kaplan (1988) concludes that tax benefits largely go to the pre-LBO stockholders, while the post-LBO equity holders only obtain the benefit of the efficiency improvements.

Employee-wealth-transfer Hypothesis: Some studies suggest that LBOs transfer wealth to investors by laying-off employees or reducing their wages. For example, Faludi (1990) finds that 63,000 workers appear to have lost their jobs following the Safeway LBO. In contrast, the findings of some empirical studies do not support the employee-wealthtransfer hypothesis: Kaplan (1988) finds no statistically significant decline in employment for up to 2 years after an LBO and the median change in employment for 
buyout companies is just $0.9 \% .^{60}$

Value Transfer between Bondholders and Stockholders: Jensen and Smith (1985) identify three primary means of transferring wealth from bondholders to stockholders: 1) unexpected increase in risk of investment projects, 2) unexpected increase in dividends, and 3) unexpected issuance of additional debt of the same or higher priority. Empirically, Jensen (1988) finds shareholder gains of $\$ 346$ billion in takeovers and restructurings from 1977 through 1986, while Asquith and Wizman (1990) find leveraged bondholder losses of $2.5 \%$ associated with successful leveraged buyouts. These findings indirectly imply the value transfer between bondholders and stockholders.

Value Transfer among Bondholders: The cost of acquiring debt in private markets is such that private creditors could press for an early liquidation (partial or complete) of the borrower when it is in financial distress (Diamond, 1993; Kaplan \& Stein, 1993; Brown et al, 1994). Early liquidation comes at the expense of other, less senior creditors and equity interests, thereby transferring value from less senior bondholders to senior private creditors. Senior private creditors that have short-term and secured debt generally have both the power and incentive to press for value reducing sales in some circumstances.

Trade-offs between the Long-term and Short-term Gains: It is possible that the shortterm gains realized come from cutting "invisible" discretionary expenses important for long-run performance (Kaplan, 1989). Maksimovic and Titman (1991) also indicate that

\footnotetext{
${ }^{60}$ In terms of methodology, Hite and Vetsuypens (1989) point out that employment levels and employment-based ratios, such as employees/sales, have to be adjusted for changes in the asset base, as LBO firms usually sell off assets.
} 
higher levels of debt may distort a firm's incentive to offer high quality products, boosting short-run profits by cutting costs at the expense of the firm's long-term reputation and profits. 


\section{APPENDIX G: EXPLANATION OF WEIGHTED MAXIMUM LIKELIHOOD ESTIMATION}

Manski and McFadden (1981) introduce the general stratified sampling process and specify the likelihood of an observation obtained through an arbitrary stratification or drawn via a random or choice-based sampling rule. Comparison of the various likelihood forms suggests that the problem of parameter estimation in choice-based samples will differ qualitatively from the estimation problem in random samples.

Manski and McFadden (1981) make a detailed statistical examination of maximum likelihood estimation of parameter vector $\theta *$ in both random and choice-based samples. They find that application of maximum likelihood is wholly classified in random samples. However, in choice-based samples, properties of the maximum likelihood estimate (MLE) depend crucially on whether the analyst has available certain prior information on sampling stratification. On the other hand, in random samples, it appears that such prior knowledge should be of little, if any, consequence. They argue that without adjustments for the sampling stratification (prior knowledge of the distribution of the exogenous variables), the standard logistic regression in choice-based samples does not provide consistent estimates $\theta *{ }^{61}$ They introduce weighted maximum likelihood estimation, the purpose of which is to weight the data to compensate for differences in the sample and population fractions of ones introduced by choice-based sampling. Manski and McFadden (1981) raise two options to produce the consistent estimators: a conditional maximum likelihood estimator (CMLE) and a weighted maximum likelihood

\footnotetext{
${ }^{61}$ Thus, one of the major contribution Manski and McFadden (1981) make is that they clarify the role that knowledge of the marginal distributions actually plays in the estimation of $\theta_{*}$ in choice-based samples.
} 
estimator (WMLE). 


\section{APPENDIX H: EXPLANATION OF THE LIMITATIONS OF STANDARD ESTIMATION METHOD UNDER CASE-CONTROL SAMPLING DESIGN}

In the context of this study, the case-control sample's numbers of observations in LBO groups or in control groups are not proportional to the size of their categories in the general population. The different sampling rates result in a technical error in the analysis of choice-based sample when standard maximum likelihood estimation is applied. Manski and McFadden (1981) argue that the disproportionate sampling for different population strata that is implicit in the choice-based sample selection would usually necessitate weighting data in statistical analyses by the sampling rates in each strata. Thus, standard estimation method is not applied in this case. Instead, weighted maximum likelihood estimation should be used to reweight observations according to differing sampling rates, thereby producing consistent estimates. 


\section{APPENDIX I: EXPLANATION OF A LOGIT EXEMPTION TO THE NEED FOR REWEIGHTING UNDER CASE-CONTROL SAMPLE}

An exception to the general need for the reweighting has been noted in the literature: In terms of standard maximum likelihood estimator used with a case-control sample, statistical studies all point out that the bias is only in the intercept parameter and other coefficients are unaltered, provided that standard logistic regression is used (Manski \& McFadden, 1981; Palepu, 1986; Hosmer \& Lemeshow, 2000; Maddala, 1991). ${ }^{62}$ Though there is no bias in estimates of logistic regressions, standard logistic regression introduces the prediction bias, under choice-based sampling for logistic model (Refer to the paper of Palepu (1986) for detailed explanation of the nature of the prediction bias). ${ }^{63}$

However, the above "logit exemption" to the need for reweighting has been used in settings where it does not apply in accounting research. Cram et al (2007) argue that the "logit exemption", which involves applying a logit model as if the sample were randomly selected, applies only to settings with choice-based such as Palepu (1986)'s sample of

\footnotetext{
${ }^{62}$ In probit model or linear probability model with choice-based sampling, adjustments still need to be made.

${ }^{63}$ Palepu (1986) provides a detailed explanation of the nature of the prediction bias. Consider a firm $i$ in the population with a probability of $p$ of being a target. Let p' be the probability that firm $i$ in the sample is a target. Palepu (1986) indicates that the use of a cut-off probability, ${ }^{p^{\prime}}$, in predicting tests, which are not equal to real probability in random samples causes bias to the statistic results.

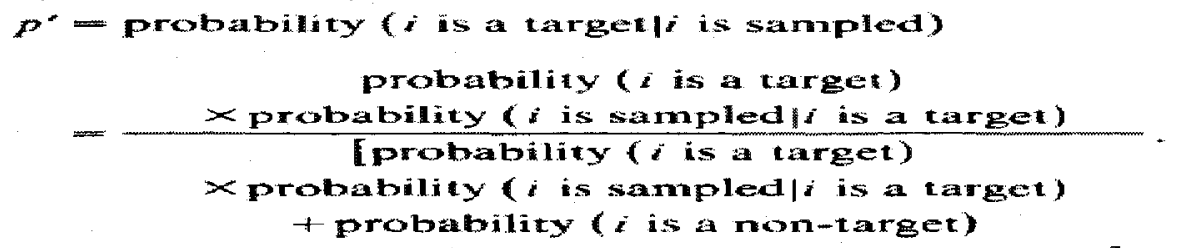

In the case of random sampling, the probability of firm $i$ being sampled is the same whether it is a target or not. Hence the above expression simplifies to p. However, under choice-based sampling, this is not so. If N1, and N2 are the number of targets and non-targets in the population and $\mathrm{n} 1$, and $\mathrm{n} 2$ are the corresponding numbers in the sample, then

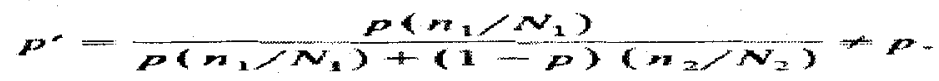


reorganized firm cases compared to a control sample selected randomly from nonreorganized firms, hence there is stratification by outcome alone. When pair-matching or other further stratification within the control sample selection is utilized, the "logit exemption" does not apply and adjustments that fully saturate the model are necessary for the logit exemption to apply. Therefore, the applicability of standard logistic regression is restricted only to non-matched case-control samples. When matching is also present, constant terms for each matched set must also be included, and each of those will be affected, but will permit accurate estimation of the research variables of interest (Cram et al, 2007). 


\section{APPENDIX J: EXPLANATION OF THE LIMITATIONS OF BOTH WEIGHTED ESTIMATION METHOD AND STANDARD ESTIMATION METHOD UNDER MATCHED CASE-CONTROL SAMPLING DESIGN}

Generally, both standard estimation method and weighted estimation method give biased parameters under matched case-control sample, which includes fully-matched and semimatched sample. Cram et al (2007) use the term "fully-matched" samples to distinguish situations in which each stratum or case-control comparison subset is unique, and "semimatched" samples which have strata or pairings of case and controls that are nominally but not meaningful unique. For example, Lehn and Poulsen (1989), Kieschnick (1998), and Maupin et al (1984)'s 1-1 matched case-control sample design is in the category of fully-matched case-control sample. Hapler et al (1999)'s sample can be classified as semi-matched case-control sample, as they select their non-LBO samples with semimatching on year.

The limitations of both weighted estimation method and standard estimation method are discussed under 1-1 matched case-control sample and semi-matched case-control sample as follows.

Standard Maximum Likelihood Estimation Method: As discussed in Appendix H, standard estimation method is not valid for non-matched case-control sampling design due to different sampling rates. Moreover, as discussed in Appendix I, standard logistic regression, a particular form of standard maximum likelihood estimation method, can not be applied to matched case-control sample either. Thus, standard maximum likelihood estimation method (including standard logistic regression) can not be applied to matched 
case-control sample.

For 1-1 matched case-control sampling design, the standard estimation method is not valid. For example, if there are $\mathrm{k}$ matched pairs, there are supposed to be $\mathrm{k}-1$ dummy variables in the model to represent each pair. Thus, number of parameters increases with sample size for 1-1 matched case-control sampling design. When the number of matched pairs in the model is large relative to the sample size, standard maximum likelihood estimates could be biased for this 1-1 matched sampling design. For semi-matched casecontrol sampling design, the standard estimation method is not valid either, since it fails to control for the levels of the matching variables.

Weighted Maximum Likelihood Estimation Method: As discussed earlier weighted maximum likelihood estimation method is valid for non-matched case-control sample. In other words, it is not valid for semi-matched or 1-1 matched case-control sample. However, we note that Halpern et al (1999) select their control samples with semimatching on year which is not accounted for in the analysis. To obtain technically correct coefficients on the research variables of interest in these datasets, Cram et al (2007) further suggest that the researcher applying a logit analysis would need to control for the levels of the matching variables by including a dummy variable for each year. If WESML is used, different weightings would have to be applied to each year's strata. While the technical error may well not have had a significant impact in these studies (having only two years of data, and those years perceived to be similar), the error may be very significant in studies involving data over different time periods. See Appendix K for the 
appropriate statistical method for 1-1 matched case-control sampling design. 


\section{APPENDIX K: EXPLANATION OF CONDITIONAL LOGISTIC REGRESSION}

Hosmer and Lemeshow (2000) describe their conditional likelihood analysis in rather general terms, for a situation in which there are $\mathrm{K}$ strata with $n_{1 k}$ cases and $n_{0 k}$ controls in each stratum $k, k=1,2, \ldots . K$. Following a conditional argument, they show an expression for the likelihood associated with each stratum.

$$
\pi_{k}(x)=\frac{e^{\alpha_{k}+\beta x}}{1+e^{\alpha_{k}+\beta x}}
$$

Note that different stratum has their own separate intercept $\alpha_{k}$, but they cancel out during mathematical manipulation. Also each strata has a separate coefficient vector $\beta$. For the case of interest here, namely 1-1 matching, this stratum likelihood reduces to

$$
l_{k}(\beta)=\frac{e^{\beta x_{x_{k}}}}{e^{\beta x_{x_{k}}}+e^{\beta x_{0 k}}}=\frac{e^{\beta\left(x_{1 k}-x_{0 k}\right)}}{1+e^{\beta\left(x_{1 k}-x_{0 k}\right)}}
$$

In this expression, $x_{1 k}$ denotes the data vector for the case and $x_{0 k}$ denotes the data vector for the control in the kth stratum or pair, and it can be seen that these enter the stratum likelihood as difference scores, analogous to a paired sample t-test. Finally, the complete conditional likelihood is the product of the $l_{k}(\beta)$ in equation G.1 over the K strata, represented by equation G.2. Therefore, the maximum likelihood estimator for $\beta$ is that value that maximizes equation G.2.

$l(\beta)=\prod_{k=1}^{k} l_{k}(\beta)$ 


\section{APPENDIX L: EXPLANATION OF PROCEDURE OF MANOVA}

Before performing MANOVA, the following assumptions required by MANOVA are carefully tested in this study.

1. The observations are independent.

2. The observations on the dependent variables follow a multivariate normal distribution in each group.

3. The population covariance matrices for the $p$ dependent variables are equal.

For the multivariate normal distribution assumption, the scatter plots for pairs of variables from SPSS are checked first. Among the nongraphical tests, SPSS DESCRIPTIVES is run to obtain Z-scores for the variables within each group. With regard to the homogeneity of variance assumption, the Levine's test is used. Then Wilk's $\Lambda$ is examined to see whether the groups differ on the set of dependent variables.

$\Lambda=\frac{\left|S S_{\text {resid }}\right|}{\left|S S_{\text {tot }}\right|}=\frac{\left|S S_{\text {resid }}\right|}{\left|S S_{\text {reg }}+S S_{\text {resid }}\right|}$

Note that $\left|S S_{\text {resid }}\right|$ indicates the amount of variability for the set of the three dependent variables that is not accounted for by regression, and $\left|S S_{t o t}\right|$ gives the total variability for the three dependent variables about their means. K-group MANOVA is used to explore the changing deal characteristics of LBOs in this study. Multiple comparisons are then performed to determine which groups and which variables are contributing to overall multivariate significance. 


\section{APPENDIX M: COMPARISON BETWEEN CONDITIOANL LOGISTIC REGRESSION AND STANDARD LOGISTIC REGRESSION}

Table M.1 shows that compared to conditional logistic regression models, standard logic regression identifies a smaller number of firm-specific variables that have significant relations with the likelihood of firms' going private via LBOs. For example, over the sub period 1990-1999, the standard logistic regression models fail to identify the effects of undistributed free cash flow and P/E for LMBOs; Over the sub period 2000-2005, the standard logistic regression models fail to identify the significant coefficients on potential tax saving and managerial ownership for LMBOs. Therefore, conditional logistic regression is more powerful in identifying the factors explaining the likelihood of firms' going private via LBOs. The empirical results based on the inappropriate statistical method (i.e. standard logistic regression) could lead to different conclusions for null hypothesis testing. One of the main reasons for the differences in results between the two statistical methods can be attributed to the fact that classical logistic regression does not take into account correlations in all explanatory factors between cases and 1-1 matched controls. 
Table M1. Standard Logistic Regression on the Likelihood of Firms' Going Private via LIBOs and LMBOs

Panel A: Standard logistic regression on the likelihood of firms' going private via LMBOs

Outliers are detected using Weisberg t-test statistic. Some outliers are then deleted after careful assessments as there are some values that seem documented wrongly in the database or are too high or low to make any financial sense.

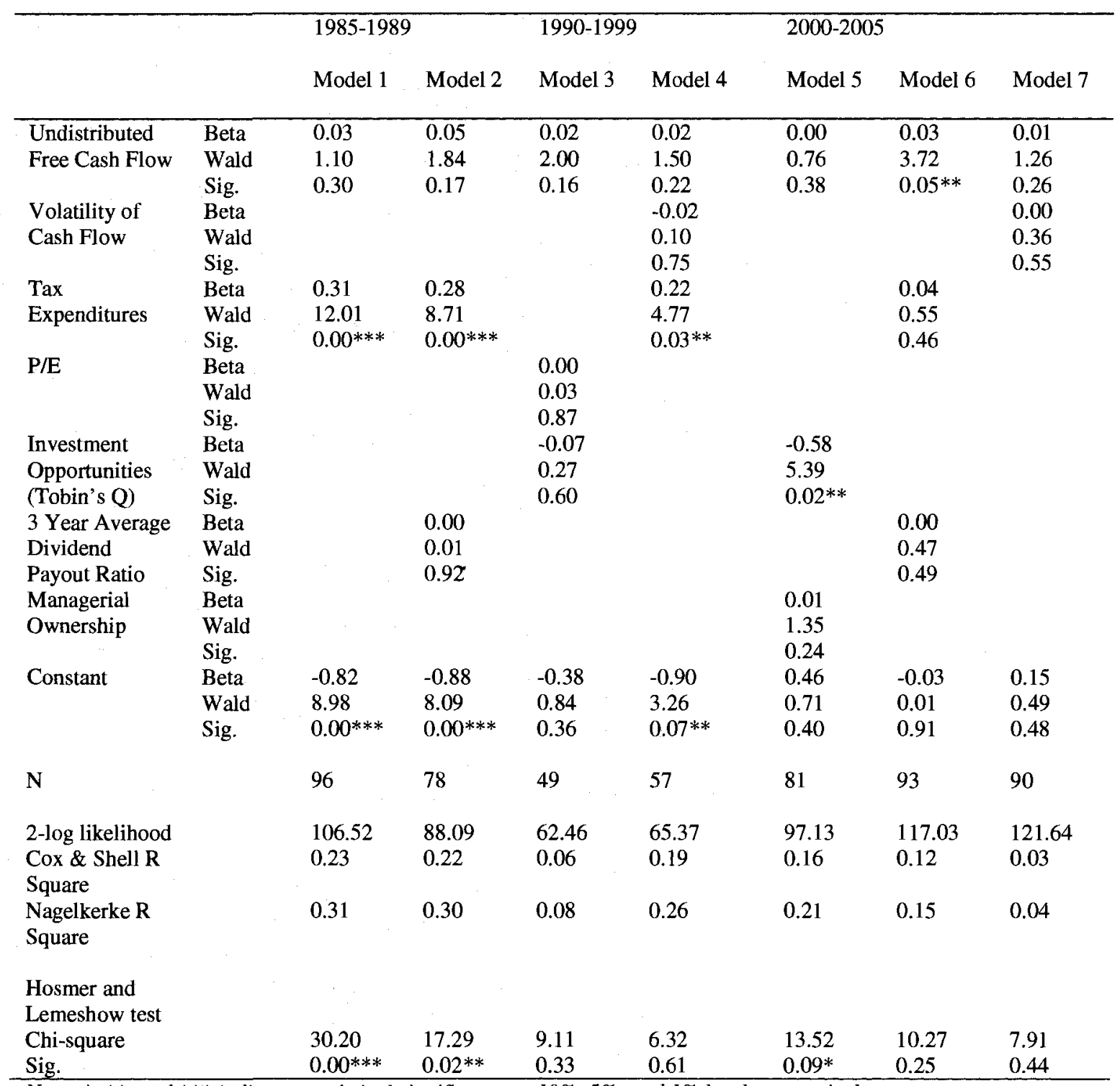

Note: $* * *$, and $* * *$ indicates statistical significance at $10 \%, 5 \%$, and $1 \%$ levels respectively. 
Panel B: Standard logistic regression on the likelihood of firms' going private via LIBOs

Outliers are detected using Weisberg t-test statistic. Some outliers are then deleted after careful assessments as there are some values that seem documented wrongly in the database or are too high or low to make any financial sense.

\begin{tabular}{|c|c|c|c|c|c|c|c|c|}
\hline & & $1995-199$ & & & $2000-200$ & & & \\
\hline & & Model 1 & Model 2 & Model 3 & Model 4 & Model 5 & Model 6 & Model 7 \\
\hline Volatility of Cash & Beta & 0.01 & & 0.01 & & -0.02 & & -0.02 \\
\hline Flow & Wald & 0.13 & & 0.06 & & 0.18 & & 0.18 \\
\hline & Sig. & 0.72 & & 0.80 & & 0.67 & & 0.67 \\
\hline Undistributed Free & Beta & 0.03 & 0.05 & 0.03 & 0.02 & 0.02 & 0.02 & 0.02 \\
\hline Cash Flow & Wald & 5.50 & 6.03 & 3.89 & 3.46 & 5.03 & 4.38 & 5.21 \\
\hline & Sig. & $0.02 * *$ & $0.01 * * *$ & $0.05 * *$ & $0.06 *$ & $0.02 * *$ & $0.04^{* *}$ & $0.02 * *$ \\
\hline Tax Expenditures & Beta & & 0.02 & 0.04 & 0.00 & & 0.02 & \\
\hline & Wald & & 0.22 & 0.70 & 0.00 & & 1.36 & \\
\hline & Sig. & & 0.64 & 0.40 & 0.96 & & 0.24 & \\
\hline $\mathrm{P} / \mathrm{E}$ & Beta & -0.03 & -0.07 & -0.03 & & & & \\
\hline & Wald & 3.74 & 5.96 & 3.64 & & & & \\
\hline & Sig. & $0.05 * *$ & $0.01 * * *$ & $0.06 *$ & & & & \\
\hline Investment & Beta & & 0.66 & & & -0.26 & & \\
\hline Opportunities & Wald & & 4.65 & & & 1.76 & & \\
\hline (Tobin's Q) & Sig. & & 0.1 & & & 0.18 & & \\
\hline 3 Year Average & Beta & & -0.03 & & & & -0.01 & \\
\hline Dividend Payout & Wald & & 0.72 & & & & 0.85 & \\
\hline Ratio & Sig. & & 0.40 & & & & 0.36 & \\
\hline Managerial & Beta & & & & -0.01 & -0.02 & & \\
\hline Ownership & Wald & & & & 0.22 & 1.61 & & \\
\hline & Sig. & & & & 0.64 & 0.21 & & \\
\hline Constant & Beta & & -0.10 & 0.51 & -0.09 & 1.27 & -0.02 & 0.10 \\
\hline & Wald & & 0.02 & 0.88 & 0.01 & 3.06 & 0.00 & 0.06 \\
\hline & Sig. & & 0.88 & 0.35 & 0.92 & $0.08 *$ & 0.95 & 0.80 \\
\hline $\mathrm{N}$ & & 52 & 47 & 50 & 40 & 50 & 56 & 62 \\
\hline 2-log likelihood & & 54.22 & 42.23 & 50.49 & 43.79 & 54.62 & 64.11 & 70.67 \\
\hline Cox \& Shell R & & 0.25 & 0.35 & 0.27 & 0.20 & 0.25 & 0.21 & 0.22 \\
\hline Square & & & & & & & & \\
\hline Nagelkerke R & & 0.34 & 0.48 & 0.37 & 0.28 & 0.34 & 0.29 & 0.29 \\
\hline Square & & & & & & & & \\
\hline Hosmer and & & & & & & & & \\
\hline Lemeshow test & & & & & & & & \\
\hline Chi-square & & 7.45 & 5.14 & 9.91 & 9.90 & 6.64 & 8.30 & 23.31 \\
\hline Sig. & & 0.49 & 0.64 & 0.27 & 0.27 & 0.58 & 0.31 & $0.00 * * *$ \\
\hline
\end{tabular}

Note: $* * *$, and $* * *$ indicates statistical significance at $10 \%, 5 \%$, and $1 \%$ levels respectively. 